UNIVERSIDADE DE SÃO PAULO

PÓS-GRADUAÇÃO INTERUNIDADES ESTÉTICA E HISTÓRIA DA ARTE

\title{
Arte Transmídia: \\ um estudo sobre uma forma de expressão artística na era digital.
}

Luciana Allegretti

DissertaÇÃo DE MESTRAdo APRESENTADA AO Programa DE PÓs-Graduação INTERUNIDADES ESTÉTICA E HISTÓRIA DA ARTE DA UNIVERSIDADE DE SÃO PAULO.

Orientador: Professor Dr. ARthUR MATUCK Linha de Pesquisa: Produção e CirculaçÃo da ARTE. 


\title{
Arte Transmídia: \\ um estudo sobre uma forma de expressão artística na era digital.
}

\author{
DissertaÇÃo de MESTRAdo APRESENTAdA AO \\ Programa dE Pós-Graduação \\ INTERUNIDADES ESTÉTICA E HISTÓRIA DA ARTE \\ DA UNIVERSIDADE DE SÃo PAULO.
}

Orientador: Professor Dr. ARTHUR MATUCK Linha de Pesquisa: Produção e CIRCUlação da ARTE.

São Paulo 2018 
Autorizo a reprodução e divulgação total ou parcial deste trabalho, por qualquer meio convencional ou eletrônico, para fins de estudo e pesquisa, desde que citada a fonte.

Assinatura: Data

Catalogação na Publicação Serviço de Biblioteca e Documentação

Faculdade de Filosofia, Letras e Ciências Humanas da Universidade de São Paulo

\author{
Allegretti, Luciana \\ A416 153 / Luciana Allegretti ; orientador Arthur \\ Matuck. - São Paulo, 2018. \\ $152 \mathrm{f}$. \\ Programa de Pós-Graduação \\ Interunidades em Estética e História da Arte da \\ Universidade de São Paulo. Área de concentração: \\ Estética e História da Arte. \\ 1. Transmídia. 2. Convergência. 3. Arte digital. 4. Hibridação. I. Matuck, \\ Arthur, orient. II. Título.
}


Nome: Luciana Allegretti

Titulo: Arte Transmídia: um estudo sobre uma forma de expressão artística na era digital.

Dissertação de Mestrado apresentada ao Programa de PósGraduação Interunidades Estética e História da Arte da Universidade de São Paulo para obtenção do título de Mestre em História da Arte.

Aprovado em:

Banca Examinadora:

Prof. Dr.

Instituição:

Julgamento:

Prof. Dr.

Instituição:

Julgamento:

Prof. Dr.

Instituição:

Julgamento: 


\section{Dedicatória}

Dedico este trabalho a Gregório Mavian Filho, minha grande inspiração sempre. 


\section{Agradecimentos}

Ao meu orientador, Arthur Matuck, meu agradecimento pela paciência e dedicação.

Aos meus colegas e amigos Denise V. Pinto, Guaracy C. da Silveira, José Antônio Corrêa, Fábio Flatschart, Fábio Goulart, Paula Maciel, Renata G. Puig entre outros que acompanharam minha trajetória e me apoiaram durante todo o percurso.

E por fim, agradeço a Vera Helena de Tarsitano Mavian e Gregório Mavian Filho por todas as palavras amigas, suporte, amizade e ajuda durante todo o percurso do mestrado. 


\section{Resumo}

Esse estudo se dedica a fazer uma reflexão sobre a arte transmidiática através da apropriação das tecnologias digitais criadas a partir do advento do computador e da internet. Apesar de não ser novo o uso de múltiplas plataformas, a conexão entre as pessoas e o grande fluxo de informação trocada pela internet possibilita um novo ambiente criativo e uma nova relação entre público e arte. $O$ trabalho tem seu início analisando a perspectiva histórica dessas novas tecnologias, que se tornaram ubíquas, e disserta sobre sua hibridação com o universo artístico, levando em conta a interatividade com o público e a cocriação. Para compreensão deste cenário tecnossocial, a pesquisa discorre sobre a penetração das novas tecnologias no cotidiano e seu impacto na sociedade.

Finalmente, o estudo apresenta e descreve uma seleção de obras que podem ser definidas ou foram criadas como transmidiáticas, e examina sua produção e circulação na sociedade.

Palavras chave: Transmídia, Arte Digital, Convergência, Hibridação, Tecnologia. 


\begin{abstract}
This study reflects on transmedia art through the use of the digital technologies that emerged with the advent of the computer and the internet. Even though the use of multiple platforms isn't new, the interpersonal links and the significant flux of data and information exchanged through the internet enables a new creative environment and a new relationship between art and its public. Observing these new and ubiquitous technologies from a historic viewpoint, this work examines its hybridization with the art world, its interaction with the public and collaborative cocreation. To comprehend this techno-social scenario, the research explains the advance of new technologies in everyday life and its impact on society.
\end{abstract}

Finally, the study presents and describes a selection of artworks that could be defined or were created as transmedia art, its production process and the way society reaches and absorbs it.

Keywords: Transmedia, Digital Art, Convergence, Hybridisation, Technology. 


\section{Lista de Figuras}

Figura 1: ENIAC (Electronic Numerical Integrator and Computer) na Filadélfia (EUA). Glen Beck (ao fundo) e Betty Snyder (à frente) programando o computador. Através do QR Code é possível assistir a um vídeo da Universidade da Pensilvânia sobre o ENIAC. Fonte: https://commons. wikimedia.org/w/index.php?curid=55124 Acesso: 21/07/2017.

Figura 2: Capa da revista "Popular Electronics" e um anúncio do kit do Altair 8800. Fonte: http://www.hardware.com.br/guias/historia-informatica/altair.html. Acesso em 01/09/2017. .29

Figura 3 : Infográfico explicativo - loT. Esse infográfico faz parte da matéria de MARQUES, que discorre sobre o investimento do governo brasileiro no 'Plano Nacional da Internet das Coisas'. No QR code abaixo é possível assistir a um vídeo institucional da Telefônica que explica a loT.

Figura 4: Penetração da internet por região. Dados coletados por KEMP, Simon (2017) com base em: Internetworldstats; International Telecommunication Union (ITU); Internetlivestats; Cia World Factbook; Facebook; National Regulatory Authorities. Fonte: https://www.slideshare.net/wearesocialsg/digital-in-2017-globaloverview?from_action=save Acesso em 10/12/2017.

Figura 5: Penetração da internet por país. Dados coletados por KEMP, Simon (2017) com base em: Internetworldstats; International Telecommunication Union (ITU); Internetlivestats; Cia World Factbook; Facebook; National Regulatory Authorities. Fonte: https://www.slideshare.net/wearesocialsg/digital-in-2017-globaloverview?from_action=save Acesso em 10/12/2017. .35

Figura 6: Tempo gasto na internet por país. Dados coletados por KEMP, Simon (2017) com base em: Internetworldstats; International Telecommunication Union (ITU); Internetlivestats; Cia World Factbook; Facebook; National Regulatory Authorities. Fonte: https://www.slideshare.net/wearesocialsg/digital-in-2017-globaloverview?from_action=save. Acesso em 10/12/2017. .35

Figura 7: Sina Weibo, o Twitter chinês. Fonte: https://i.ytimg.com/vi/Fc3N1eBM44E/maxresdefault.jpg Acesso em: 20/12/2017.....39

Figura 8: Pode-se usar como exemplo a campanha da Coca Cola de 1953 a 1955, "There's nothing like a Coke", utilizava o mesmo slogan, jingle e linguagem visual em suas propagandas (cartaz, revista e TV).

Figura 9 Gráfico sobre intermídia de Higgins - O gráfico mostra círculos de forma concêntrica, que se sobrepõem e aparentam expandir-se e contrair-se em relação à 
moldura da "Intermídia" que os engloba. (tradução livre da legenda, HIGGINS, 2001).

Figura 10: Exemplo de Haiga, retrato e poema de Matsuo Basho pelo artista Yokoi Kinkoku. Era Edo, 1820. Fonte: http://folhadepoesia.blogspot.com.br/2015/01/haikuum-caminho-pessoal-de.html. Acesso em 18/07/2017.

Figura 11: Shiomi Mieko, Sonho Amplificado, década de 60. Disponóvel em: http://post.at.moma.org/content_items/241-intermedia-transmedia

Figura 12 Desempenho do Sonho Amplificado de Shiomi Mieko durante a Intermedia Crosstalk. Disponível em: http://post.at.moma.org/content_items/241-intermediatransmedia.

Figura 13: Exemplo de transmídia na franquia The Matrix. (RUTLEDGE, 2013, Slide 31) Fonte: https://pt.slideshare.net/pamelarutledge/transmedia-storytelling-as-acontent-marketing-strategy/27.

Figura 14: Museu interativo Art on Island nas Filipinas, onde o visitante tira fotografias interagindo com famosas obras de arte. Imagem disponível em: http://www.criatives.com.br/2015/03/museu-interativo-3d-nas-filipinas-faz-com-quevoce-entre-dentro-das-pinturas/ Acesso 26/05/2016. 52

Figura 15: Site que disponibiliza Memes com obras clássicas. Disponível em: https://me.me/t/classic-art?since $=1465125250 \% 2 \mathrm{C} 703773 \% 2 \mathrm{C} 1.000000$. Acesso: $15 / 10 / 2017$

Figura 16: The Apparition of Christ to the People, de Alexander Andreyevich Ivanov. Fonte: https://www.google.com/culturalinstitute/beta/asset/the-apparition-of-christ-tothe-people-the-apparition-of-the-messiah/lgGqUffODe21kA. Acesso: 10/01/2018. .54

Figura 17: Detalhe aproximado com as figuras escondidas atrás da árvore. Fonte: https://www.google.com/culturalinstitute/beta/asset/the-apparition-of-christ-to-thepeople-the-apparition-of-the-messiah/lgGqUffODe21kA. . Acesso: 10/01/2018. .....54

Figura 18: Oscar Gustave Rejlander, Os dois caminhos da vida (1875) é a sua obra mais conhecida e possivelmente uma das mais paradigmáticas feitas através da técnica da fotomontagem. Para a sua realização foram utilizados mais de trinta negativos diferentes. Fonte: https://commons.wikimedia.org/wiki/File:Oscar-gustaverejlander_two_ways_of_life_(HR,_sepia).jpg. Acesso: 01/01/2017.

Figura 19: Muybridge à esquerda, Nu descendo escada, fotografia, 1887. Fonte: https://www.researchgate.net/publication/37986855_Understanding_Human_Motion_ A_Historic_Review. Acesso: 21/09/2017. À direita, Marcel Duchamp, Nu descendo uma escada o 2, óleo sobre tela, 1912. Fonte: 
https://en.wikipedia.org/wiki/Nude_Descending_a_Staircase,_No._2.

Acesso:

21/09/2017

Figura 20: À esquerda, Etienne-Jules Marey, Homme qui marche, fotografia, 1883. Fonte: https://fr.wikipedia.org/wiki/\%C3\%89tienne-Jules_Marey\#/media/File:Marey_Man_walking,_1890\%E2\%80\%9391.jpg. Acesso: 21/09/2017.

Figura 21: TV De-coll/ages, Wolf Vostel, 1958. Fonte: http://www.medienkunstnetz.de/works/tv-decowage/images/2/. Acesso 05/08/2017.

Figura 22: Imagens extraídas de Catalog (1961), John Whitney. Fonte: https://www.youtube.com/watch?v=TbV7loKp69s. Acesso: 05/08/2017.

Figura 23: Óculos de VR (realidade virtual) de papelão da marca Google. Eles podem ser acoplados a telefones celulares Fonte: https://www.amazon.com/Google87002822-01-Official-Cardboard/dp/B01L92Z8D6. Acesso: 10/12/2017.

Figura 24: Kit de realidade virtual da marca HTC Vive. Fonte: https://www.vive.com/us/product/vive-virtual-reality-system/. Acesso: 10/12/2017...67

Figura 25: Criação virtual a partir do app Tilt Brush. Fonte: https://www.tecmundo.com.br/realidade-virtual/113617-tilt-brush-google-torna-opensource-plataforma-pintar-vr.htm. Acesso: 10/12/2017.

Figura 26: Imagem retirada do vídeo de apresentação da exposição Reblink. O vídeo demonstra como as imagens dos quadros se apresentam a partir da observação mediada pelo celular. Fonte: https://www.ago.net/reblink. Acesso: 10/12/2017.......68

Figura 27: Capa do disco da peça Illiac Suit. Fonte: http://www.computerhistory.org/timeline/1956/ Para ouvir a primeira parte da obra utilize o QR code ao lado. 69

Figura 28 Shiomi Mieko e Alison Knowles durante a apresentação de Disappearing Music for Face, na Washington Square Gallery em Nova lorque. Foto de Peter Moore. (C) Barbara Moore / Licenciado pela VAGA, NYC. Disponível em http://post.at.moma.org/content_items/241-intermedia-transmedia. Acesso em $12 / 01 / 2018$ .75

Figura 29 Imagem do filme Disappearing Music for Face (FluxFilm no. 4), 1965, gravado por Peter Moore, interpretado por Yoko Ono, produzido por George Maciunas. A imagem foi retirada do vídeo veiculado no Youtube, disponível em https://www.youtube.com/watch?v=9qAjQVKQgUQ, Acesso em 12/01/2018. No QR code ao lado é possível assistir ao vídeo. 76 
Figura 30 Flipbook do filme Disappearing Music for Face (FluxFilm no. 4), Disponível em: https://www.printedmatter.org/catalog/14792/. Acesso em 12/01/2018.

Figura 31 Página final do Flip Book "Disappearing Music for Face". Nesta página se concentram os créditos da obra criada por Shiomi Mieko, interpretada por Yoko Ono e fotografada por Peter Moore. Essa edição foi impressa em 2002. Imagem disponível em http://post.at.moma.org/content_items/241-intermedia-transmedia\#Fig 5-8 jump. Acesso em 12/01/2018.

Figura 32: Le Café Nuit (The Night Café), Vincent Van Gogh, óleo sobre tela, 1888. Fonte: https://artgallery.yale.edu/collections/objects/12507. .78

Figura 33: Imagem extraída do vídeo demonstrativo do ambiente virtual criado por Mac Cauley. Através do QR code é possível assistir ao vídeo da obra no Youtube. Fonte: https://www.youtube.com/watch?v=IJKh3prqBal .78

Figura 34: imagem do trailer do filme "A paixão de Van Gogh", de 2017. No QR code ao lado, é possível assistir ao trailer. Fonte: http://www.adorocinema.com/filmes/filme-241757/trailer-19557147/ .79

Figura 35 Rasheedah Phillips \& Moor Mãe realizando "Ritual Causality 003", 2017, festival Transmediale. Disponível em: https://transmediale.de/de/content/ritualcausality-003-0. Visualizado em 12/01/2018.

Figura 36: Algumas imagens da instalação participativa (Errar de Dios). Através do QR Code da imagem, é possível ouvir aos sons gravados da instalação. Composição de fotos feitas na Bienal pela autora. O esquema da instalação pode ser conferido em https://errardedios.org/textos-texts/, Acesso 01/03/2016. 82

Figura 37: Imagens do Vídeo "Pixel Pixo - Poesia Pixel". Através do QR Code abaixo, é possível visualizar um vídeo da performance. Disponível em: https://www.youtube.com/watch?v=gzMQ0lcVxzA. Visualizado em 5/7/2017. .85

Figura 38: Site do Kynemas Fluxuz, com frames de diversos vídeos. Disponível em https://kynemasfluxuz.wordpress.com/. Acesso 12/12/17.

Figura 39: Kynemas Fluxuz no https://www.facebook.com/kynemas.fluxuzfilme. Acesso em 12/12/17. .................87

Figura 40: Kynemas Fluxuz no Twitter. https://twitter.com/Kynemas. Avesso $12 / 12 / 2016$

Figura 41: Kynemas Fluxuz no Youtube. https://www.youtube.com/channel/UCp0yttecLTg2yjddSPPb7oQ. Acesso $12 / 12 / 2017$ 
Figura 42: Kynemas Fluxuz no vimeo. Diversos filmes diferentes disponíveis. https://vimeo.com/channels/284582/videos. Acesso em 12/12/2017.

Figura 43: Acima: Perfis fictícios dos personagens de "Eu - Negociando Sentidos" no Facebook. Abaixo: Imagens das gravações feitas através de diversas câmeras colocadas dentro do espaço cenográfico da casa. Ao lado esquerdo, um exemplo de diálogo do espectador com as personagens. Através do $Q R$ code, é possível ver o vídeo explicativo de apresentação da peça. Fonte das imagens de câmera: https://www.guiadasemana.com.br/sao-paulo/arte/evento/eu--negociando-sentidosteatro-do-centro-da-terra-11-10-2012 Acesso 12/06/2016.

Figura 44: Grafite digital, O Enigma de Voynich, por Achiles Luciano, 2017. Fonte: https://catracalivre.com.br/sp/spetaculo/gratis/excompanhia-de-teatro-lanca-dramaem-audio-3d-e-grafite-digital/ No QR code ao lado é possível assistir a um tutorial do aplicativo. 92

Figura 45: Imagem ilustrativa do uso do aplicativo em seu vídeo de divulgação disponível em http://www.excompanhiadeteatro.com.br/voynich. Acesso 16/12/2017

Figura 46: O Enigma de Voynich no Google Playstore, captura da tela diretamente do celular.

Figura 47: moZaico de voSes, de Martha Gabriel. À direita, projeção do moZaico de voSes em tela e instalação do trabalho no SIGGRAPH 2006. Através do QR code ao lado, é possível ver um exemplo da obra em funcionamento. Fonte: http://www.martha.com.br/mozaico-de-voses/. Acesso 14/12/2017

Figura 48: Sensitive Rose de Martha Gabriel. Ao lado, o QR Code leva a um vídeo demonstrativo da obra.

Figura 49: Registro fotográfico da apresentação de Fragmentos. Na imagem, Lopreto faz lightpainting. No QR code ao lado, é possível assistir a um trecho da performance no Youtube. http://www.cursodehistoriadaarte.com.br/lopreto/index.php/page/2/.......................98

Figura 50: Fragmentos - Ensaio III - Solo performer Lopreto - Foto Felipe Costa Ibirapuera São Paulo. Fonte: Imagens cedidas por Lopreto.

Figura 51: fragmentos - Ensaio XVI, solo performer Lopreto, intérprete dos poemas Osmar Amorim, música Daniel Muray, fotografia Fabiana Stig - MIS (Museu da Imagem e do Som São Paulo 2012. Fonte: Fotos cedidas por Lopreto. .99 


\section{Sumário}

Introdução 16

1.10 computador, World Wide Web e dispositivos móveis ......................................23

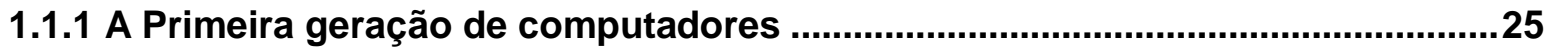

1.1.1.1 Os microcomputadores e os computadores pessoais ....................................28

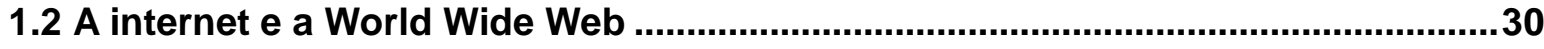

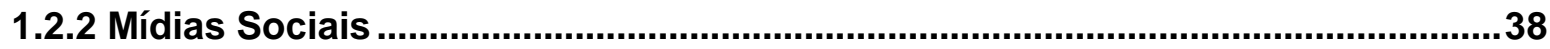

1.3. Múltiplas mídias, múltiplos conceitos ................................................................40

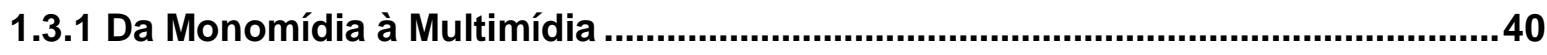

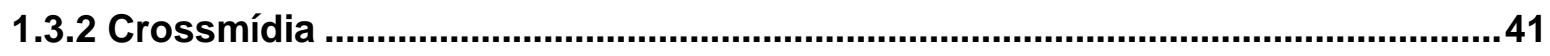

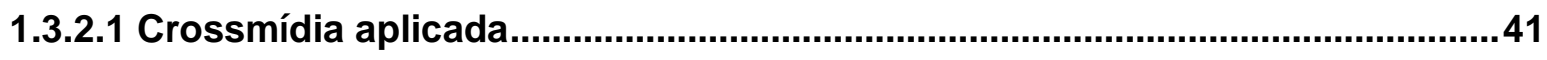

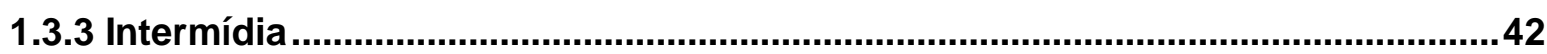

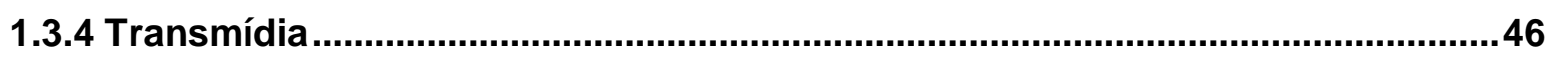

1.3.5 Hipermídia ...................................................................................................49

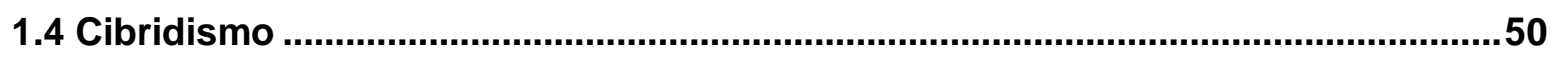

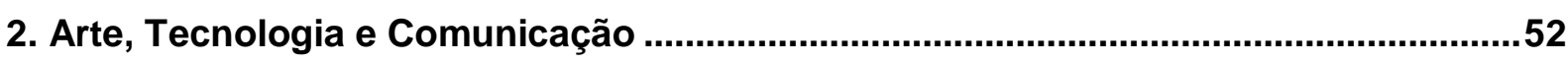

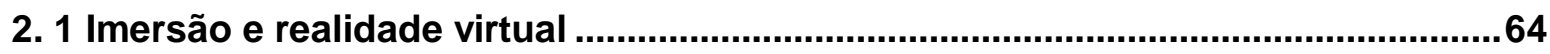

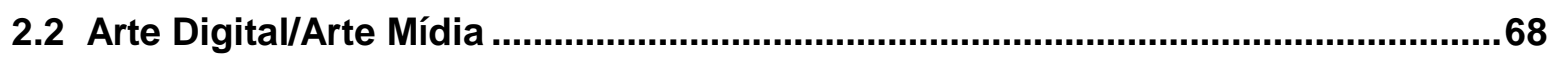

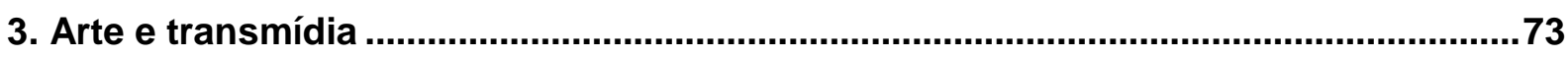

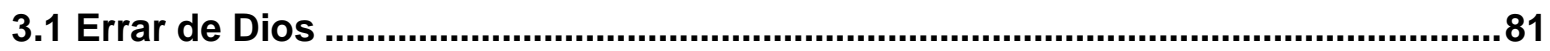

3.2 Pedro Paulo Rocha, artista transmidiático..........................................................84

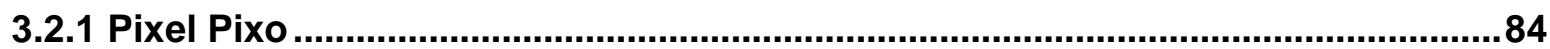

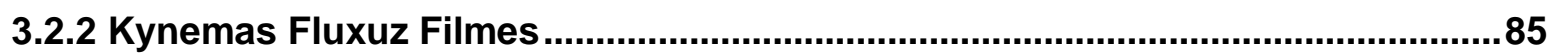

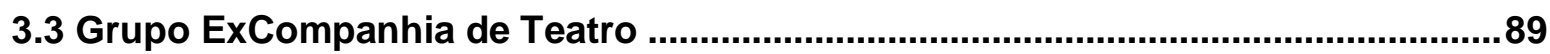

3.3.1 EU - Negociando Sentidos..............................................................................89

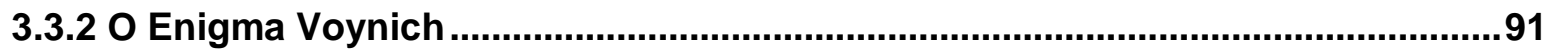

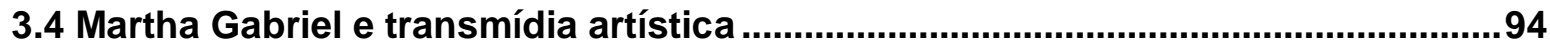

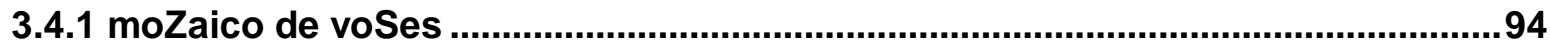

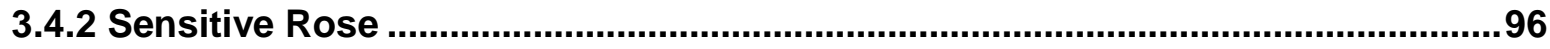

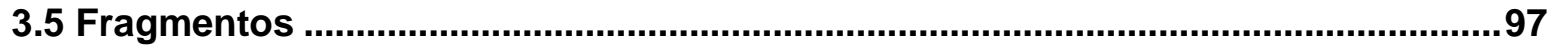

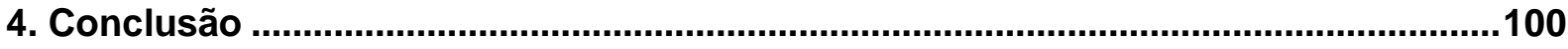

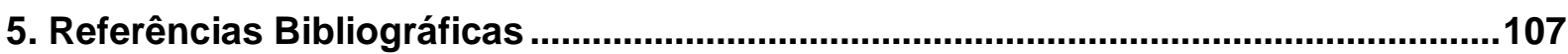

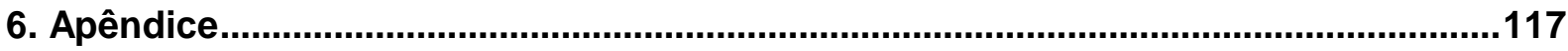

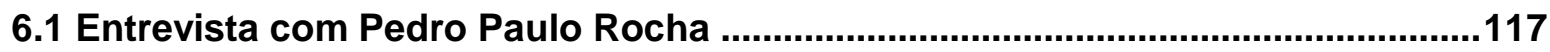


6.2 Entrevista com Bernardo Galegale e Gustavo Vaz .132

6.3 Entrevista com Luis R. Lopreto .150 


\section{Introdução}

Esse estudo visa a levantar questionamentos sobre a apropriação da forma transmídia por manifestações artísticas de base tecnológica com a finalidade de se construir mensagens multifacetadas.

Reflete sobre o âmbito da hibridação e experimentação das atuais plataformas e sobre as ferramentas computacionais e mídias emergentes na ampliação da possibilidade expressiva de criação, interatividade e circulação do objeto artístico. Tais obras multiplatafórmicas que convergem, não apenas para construir uma narrativa, mas também para desenvolver um discurso poético, são destacadas neste trabalho como obras transmidiáticas ${ }^{1}$.

Para esse fim, aborda aspectos históricos da evolução tecnológica e midiática a fim de embasar o contexto tecnossocial em que essas obras estão inseridas. Discute a aplicação gradativa desses meios que se tornaram ubíquos no cotidiano e a crescente conectividade e troca de informação entre as pessoas. Posiciona a obra artística no contexto contemporâneo, quando a necessidade de compartilhar e absorver informação e cultura é parte do que define a percepção e forma de pensar do homem.

O avanço inexorável da tecnologia ampliou drasticamente os meios de intercomunicação, em especial na história mais recente. Dos touros e cavalos do homem magdaleniano em Lascaux ${ }^{2}$ aos estudos impactantes dos limites humanos de Marina Abramović ${ }^{3}$; das palavras firmes, mas carregadas de emoção de Walter Cronkite ${ }^{4}$ confirmando a morte de John F. Kennedy à revelação da paternidade de Darth Vader a Luke Skywalker ${ }^{5}$; do discurso inflamado de Gromash Hellscream à

\footnotetext{
${ }^{1}$ Transmídia: o uso de multiplataformas para transmitir uma história ou conteúdo de forma complementar.

${ }^{2}$ Complexo de Cavernas na França, muito conhecido pelas suas pinturas rupestres.

${ }^{3}$ Marina Abramović (Belgrado, Sérvia, a 30 de novembro de1946), uma das precursoras da arte performática. Esteve no Brasil em 2015 com a exposição "Terra Comunal" no Sesc e viajou pelo país para gravar seu documentário "Espaço Além - Marina Abramović e o Brasil".

${ }^{4}$ Walter Cronkite (1916-2009), famoso jornalista americano, considerado formador de opinião de alta credibilidade.

${ }^{5}$ No filme Guerra nas Estrelas (Star Wars) episódio V - o império contra ataca, de George Lucas, 20th Century Fox, 1980.
} 
beira do Portal Negro no videogame Warcraft ${ }^{6}$, às luzes tricolores que iluminaram a torre Eiffel numa chocada e aterrorizada Paris em Novembro de $2015^{7}$, infinitas histórias foram contadas.

Cada uma das histórias acima foi exposta em diferentes formas e em veículos diversos. Claramente, essa propagação moderna das mídias possibilita vários meios de transmitir uma mensagem - mas, muito mais do que isso - torna possível a composição de uma mesma história através de diversas mídias.

As razões para diversificar os prismas midiáticos neste contexto são diversas. O fã de uma série de suspense se sentirá compelido a procurar pistas sobre os assassinos no site oficial da trama. O personagem secundário de um blockbuster de ação torna-se mais popular do que os personagens principais, e recebe um jogo de videogame em que ele é o protagonista (da história). Chamadas breves de notícias em aplicativos de celular trazem versões resumidas e aludem ao conteúdo denso, que será discutido num programa de mesa redonda na televisão. Marketing, informação e fidelidade do consumidor são motivos claros e práticos para a diversificação dos meios. Mas, seriam os únicos?

Uma determinada História da Arte contemporânea estuda a hibridação entre arte e tecnologia e seus efeitos sobre o pensamento no processo e realização artística, desde o século passado. A circulação da informação, através de diversos meios de comunicação transforma e informa o domínio artístico em dois pontos: no registro de sua circulação e no registro interartístico (ou conteúdo das obras). (CAUQUELIN, 2005).

No registro interartístico, de acordo com o autor Michael Rush, no livro Novas Mídias na Arte Contemporânea (2006), uma tendência importante no século XX é o questionamento da tradição da pintura como meio privilegiado de representação. $\mathrm{O}$ foco artístico muda da expressão "objetiva" para pessoal. Além disso, a "natureza experimental" faz parte do cotidiano artístico, ao romper os limites clássicos da arte, através da incorporação de novos materiais tais como a anexação de objetos

\footnotetext{
${ }^{6}$ Gromash Hellscream é um personagem do jogo on-line de MMORPG (Massive Multiplayer Online Role-Playing Game) World of Warcraft, na quinta expansão do jogo Warlords of Draenor.

${ }^{7}$ Referente aos atentados terroristas na noite de 13 de novembro de 2015.
} 
prontos (ready-mades) e fragmentos do cotidiano como, por exemplo, recortes de jornais. O uso de meios tecnológicos para expressão de ideias torna-se cada vez mais comum. ${ }^{8}$

\begin{abstract}
A vanguarda do final do século $X X$, se é que devemos chamála assim, é aquela que engaja a revolução mais duradoura em um século permeado por revoluções: a revolução tecnológica. Iniciada por invenções fora do mundo artístico, a arte baseada na tecnologia (englobando uma variedade de práticas de fotografia, filme, vídeo, realidade virtual e muito mais, entre outras) direcionou a arte para áreas outrora dominadas por engenheiros técnicos (RUSH, 2013, p.2).
\end{abstract}

Na circulação das obras, Zanini (2003) afirma que já está presente na Arte Telemática $^{9}$ (que conecta tecnologias de comunicação como telefones, satélites, fibras óticas, computadores, redes, softwares, etc.), o uso da interatividade, da imaterialidade (ciberespaço nas redes) e das linguagens poéticas contemporâneas, através de meios tecnológicos.

Estreita-se, portanto o relacionamento entre arte, ciência e tecnologia. É um momento complexo em que diversas disciplinas convergem e estabelecem novas relações entre público e obra. A postura contemplativa não é mais suficiente e o observador é convidado a participar e muitas vezes interferir nos processos artísticos. Uma obra de arte pode ter alcance mundial, através da internet, e ser vista e modificada por milhões de pessoas consecutivamente.

Dentro desse cenário tecnossocial, nasce no século XXI a palavra transmídia, que pretende nomear a construção de uma informação ou história através de diversas mídias diferentes de forma a se complementarem. Cada meio deve ser explorado com suas potencialidades para transmitir a mensagem.

A história da arte tecnológica registra que as estratégias e os próprios meios de comunicação em massa (TV, cinema, jornal) foram apropriados pelo discurso artístico. Analogamente, a transmídia atualmente desponta como um novo meio de expressar um discurso poético.

\footnotetext{
${ }^{8}$ RUSH, Michael. Novas mídias na arte contemporânea. Martins Fontes, São Paulo, 2013.

${ }^{9}$ Telemática - palavra cunhada em 1977 por Simon Nora e Alain Minc.
} 
Em uma obra artística transmidiática, a intenção foge aos objetivos mercadológicos desta técnica comunicacional quando utilizada especialmente no marketing. A criação transmidiática pretende estimular o observador, não apenas sensorial, mas também psicologicamente, inserindo-o muitas vezes como participante do processo artístico.

Esse estudo se propõe a refletir sobre essa nova manifestação artística, a forma transmídia, baseada em tecnologias digitais. Questiona se a arte transmidiática ocorre como consequência da necessidade contemporânea de interatividade tecnossocial ou pela viabilidade ferramental disponível aos artistas, a partir da tecnologia digital.

Pouquíssimos são os textos sobre o assunto, e em sua maioria atendem à disciplina de comunicação. Também é embrionário o uso do termo entre os artistas. Por esta razão, além de livros e artigos acadêmicos, a pesquisa compreende entrevistas com alguns dos artistas citados, vídeos informativos e artísticos e dados levantados através da internet.

Para contextualizar essa dissertação, é necessário localizar a obra de arte dentro desse universo tecnológico digital - em que vídeo, som, artes visuais, websites, redes sociais, tecnologias móbile, realidade aumentada, e outros veículos de informação e cultura fazem parte de um processo de hibridação artística que poderia ser chamada de transmidiática - e compreender historicamente a evolução dessas tecnologias (mídias subsequentes) e seu impacto e absorção pela população.

Para atingir o objetivo dessa dissertação, o primeiro capítulo discorre sobre a evolução do ambiente tecnossocial desde a criação das máquinas computacionais, da internet, das redes sociais, e lança luz na diversidade de termos relacionados à palavra mídia. Esse capítulo é importante para esclarecer como as tecnologias digitais foram criadas e a partir de que momento se tornaram parte do cotidiano humano a ponto dos artistas a elas terem acesso, possibilitando que a transmídia artística ocorra além dos meios analógicos. 
Se o primeiro capítulo (Contexto da tecnocultura digital na sociedade) recorre à bibliografia da comunicação (já que transmídia é um vocábulo criado para identificar uma forma de expressão na área), no segundo capítulo (Arte, Tecnologia e Comunicação), o objetivo é identificar como as tecnologias digitais permearam o universo artístico e como os artistas se apropriaram das ferramentas computacionais para sua obra, abrindo espaço para uma obra transmidiática. Discute, portanto, arte digital, ou artemídia em uma perspectiva histórica, desde seu estágio primitivo às tecnologias atuais.

O terceiro capítulo (Arte e transmídia) identifica a transmídia dentro do universo artístico contemporâneo. Cria uma metodologia elaborada a partir do embasamento dos dois primeiros capítulos para selecionar e analisar oito obras consideradas como transmidiáticas.

A conclusão faz uma ponderação do embasamento histórico levantado nos capítulos iniciais e sua associação ao termo transmídia. Discute sobre as obras citadas e sua relação à problemática do trabalho, conceituando, por fim, transmídia com ênfase na diferença da aplicação do termo na comunicação e na arte respectivamente. 


\section{Contexto da tecnocultura digital na sociedade}

A humanidade está imersa em tecnologia desde os tempos primitivos. É, afinal, intrínseco ao homo sapiens o uso de ferramentas - é o que o difere dos incontáveis organismos da Terra. As fagulhas da inovação, da adaptação e da curiosidade movem o ímpeto humano na busca infindável por novas formas de interagir, compreender e controlar seus arredores.

Desde o manuseio do fogo, a utilização da roda ou o advento da escrita, a história humana influencia e é influenciada pelos avanços tecnológicos. Durante milênios, a inovação caminhou a passos lentos - contida por dogmas, barreiras político-sociais e limitações de recursos. Mas com a chegada da Revolução Industrial, houve uma aceleração tecnológica vertiginosa. Nas décadas que se seguiram, até os tempos atuais, o conhecimento se propagou de maneira tão veloz que se tornou difícil de ser seguido.

Da mesma forma que as primeiras Revoluções Industriais dos séculos XVIII e XIX tiveram um impacto profundo e revolucionário no caminhar da humanidade, a chamada Terceira Revolução Industrial $\left(\mathrm{TIR}^{10}\right)$ traz outras mudanças gigantescas no panorama mundial.

GREENWOOD (1997) e RIFKIN (2011) sinalizam o advento da TIR nos meandros do século $X X$ - o despontar de uma nova ordem que alterou paradigmas socioeconômicos através do globo. A ela se deve a multiplicação dos meios de comunicação a partir da tecnologia digital.

Inicialmente, a interatividade midiática ocorria através da comunicação privada nas cartas (pelo correio), que foram sucedidas e concomitantemente usadas pelo telégrafo e pelo telefone. O rádio, que em um primeiro momento, era usado para fins militares de navegação, em seu modelo comercial tornou-se uma mídia de massa, não possibilitando a interação do receptor. A televisão seguiu esse mesmo modelo de comunicação em que a informação é transmitida unidirecionalmente, servindo como instrumento de propaganda. (MATUCK, 2009)

A mídia impressa (jornais, revistas, livros) e o cinema (em sua criação) também não previam interatividade com o receptor final; a informação era

\footnotetext{
${ }^{10}$ Third Industrial Revolution.
} 
transmitida por cada meio, e recebida pelo público de forma passiva. Essa comunicação em massa era, portanto, unilateral, institucionalizada e produzida num modelo de escala industrial.

Divergindo destes meios, a internet trouxe interatividade, customização, rapidez e miríades de opções à forma que se coleta, processa e distribui informação. Com a velocidade da telefonia somada às bibliotecas virtualmente ilimitadas da rede mundial, instaurou-se um meio de disseminação de conhecimento acessível e universal, uma forma de troca de informações em que todos os usuários estão integrados.

A infraestrutura da TIR inteligente e a Internet das Coisas conectarão todos e tudo em uma rede sem costura. Pessoas, máquinas, recursos naturais, linhas de produção, redes de logística, hábitos de consumo, fluxos de reciclagem, e praticamente todos os outros aspectos da vida econômica e social são ligados através de sensores e softwares [...] continuamente alimentando Big Data [...] (RIFKIN, 2011, p.18)

A ampla abrangência da comunicação digital possibilitou uma mudança drástica na forma em que se adquire conhecimento e informação. Essa mudança de paradigma alterou a percepção humana, que passa a criar novas relações intercomunicacionais entre meio e mensagem, forma e conteúdo. (JOHNSON, 2001)

A internet, nascida nos anos 60 e popularizada nos anos 90, estabeleceu a forma atual de comunicação, através de documentos multimídia (combinando imagens, textos, sons, vídeos, etc.) disponíveis em um complexo mapa de hipertexto (onde a partir de palavras chaves, novas informações podem ser adquiridas em uma série de outras páginas da web).

A forma de comprar, vender, comunicar, visualizar, expor e divulgar foi transformada pela internet e pela tecnologia digital. Empresas tiveram que se atualizar criando e-commerce para não perder vendas; os jornais se debatem entre manter a mídia impressa e o controle de conteúdo de notícias na web para não perder assinantes; as redes de TV ainda procuram soluções viáveis para competir com sites de vídeos e streaming como o Youtube e a Netflix. A mídia digital toca atualmente todos os campos de interação social, individualmente ou em grupo e 
permeia a percepção de mundo do ser humano, fazendo parte de suas relações diárias afetando até mesmo as esferas institucionais.

O termo transmídia, cunhado inicialmente por Henry Jenkins em seu livro "Cultura de Convergência"11, define o uso de múltiplas mídias (digitais e analógicas) para transmitir um conteúdo complementar.

Transmedia storytelling refers to a new aesthetic that has emerged in response to media convergence - one that places new demands on consumers and depends on the active participation of knowledge communities. (JENKINS, 2009, posição 563, 209) ${ }^{12}$.

A tendência transmidiática vem se ampliando na comunicação contemporânea - seja no cinema, jornalismo, televisão ou mesmo internet, de modo tal que os conteúdos já são elaborados tendo em vista uma simultânea ou posterior plataforma múltipla e integrada da informação.

\subsection{O computador, World Wide Web e dispositivos móveis}

Atualmente, é possível verificar que um dos campos que mais conquistou avanços é o da comunicação, já que há poucas décadas, era impensável a transmissão de dados em escala tão grandiosa e tão rápida através do globo. Ainda que o advento da nova comunicação globalizada não tenha tido o mesmo efeito de aproximar as pessoas fisicamente, a propagação digital de conhecimento transformou a maneira com que a informação é divulgada e assimilada. Este efeito quebrou barreiras de espaço e tempo, afetando a sociedade como um todo, assim como a cultura, o trabalho, e o cotidiano humano.

Noções como a de lugar passam a demandar um refinamento de acepção, sobretudo porque o ponto de vista da ressonância, as topografias passam a disputar espaço com topologias de variáveis relacionais e associativas. No limite, diríamos que o uso qualificado do espaço se torna

\footnotetext{
11 JENKINS, Henry. Cultura de Convergência. Editora Aleph, 2009.

12 Transmedia storytelling refere-se à nova estética que emergiu em resposta à convergência midiática - uma que coloca novas demandas aos consumidores e dependem da participação ativa das comunidades de conhecimento. (livre tradução)
} 
modelização de códigos sempre renovados pelos meios de comunicação em expansão (MACHADO, 2015, p.72).

A fala, a escrita e os diversos mecanismos de telecomunicação (telégrafo, telefone e fax, entre outros) são responsáveis pelo crescimento gradativo da conexão entre as pessoas. A invenção e a popularização do computador e o advento da internet (discada, a princípio, e depois em banda larga) nos introduziu em uma era digital de troca de dados em velocidade sem precedentes.

Em tempos de tecnologia digital, está ao alcance das mãos (24 horas por dia), o acesso a informações de todo o planeta e é possível conversar com pessoas do outro lado do mundo em tempo real.

Grandes quantidades de conteúdos de diversas origens estão disponíveis na web, tanto em blogs, vídeos (Youtube), redes sociais (como Facebook) como em enciclopédias colaborativas virtuais, como a Wikipédia. Esse volume enorme de informações é chamado de Big Data, e muitas vezes necessita de uma mediação para manipulação de seu conteúdo (buscadores como o Google, Bing e Yahoo, por exemplo).

No campo acadêmico, o estudo, a pesquisa e o ensino que mesclam a tecnologia digital com o conhecimento humano catalogado desde a pré-história, foram nomeados como "Digital Humanities". Esse termo ainda é muito discutido dentro da academia, tanto em relação a sua validade (já que humanidades são humanidades, sejam em forma digital ou impressa), quanto à própria resistência de alguns estudiosos em absorvê-la. ${ }^{13}$ Entretanto, a internet facilitou os estudos transdisciplinares, possibilitando a relação colaborativa entre pesquisadores de diferentes áreas de estudo.

[...] Marcadamente, a partir da instalação da World Wide Web (a rede mundial de computadores comercial, de interface gráfica tal como a conhecemos hoje) nos primórdios dos anos 1990 e as contínuas (re)evoluções desde então, assistimos a uma gradativa dissolução de fronteiras entre o conjunto de paradigmas-teorias-modelos-metodologias vinculados à delimitação da Comunicação como campo de estudo da transmissão de mensagens por meio de dispositivos de mídia; e a busca de

${ }^{13}$ CHUN, Wendy Hui Kyong, RHODY, Lisa Marie. Working the Digital Humanities: Uncovering Shadows between the dark and the light. 
referenciais e correlações em outros campos científicos das próprias Ciências Sociais - a exemplo da Sociologia, da Antropologia, ampliando para a Psicologia, a Economia, a Ciência da Informação, o Design e a Arquitetura e dialogando com a Geografia, a Cibernética, a Matemática e até mesmo as Engenharias (CORRÊA, 2015, p.3).

A telefonia móvel foi criada a princípio apenas para comunicação verbal. No entanto, a evolução natural do telefone fixo, transformou-o em um aparelho multifuncional, usado constantemente, quase como uma "ciberextensão" do próprio corpo.

\subsubsection{A Primeira geração de computadores}

A criação do computador seguiu a mesma lógica de outras ferramentas criadas pelo homem: a necessidade de resolver problemas. Seu berço está na lógica e na matemática e é consequência de séculos de estudo estruturados por nomes que vão desde Aristóteles, até Alan M. Turing ${ }^{14}$ (1912-1974) e David Hibert ${ }^{15}$ (18621943), entre outros. (FONSECA FILHO, 2007).

Os computadores do século XXI ainda têm muito em comum com as enormes máquinas do pós-guerra, no que se refere ao mesmo princípio e fundamento: processamento de informações em larga escala e armazenamento. Entretanto o desenvolvimento de hardware e software, que foi se acelerando no devir dos anos, elevou-os a um patamar que dificilmente poderia ser previsto pelos seus pioneiros.

Os primeiros dispositivos computacionais surgiram por volta da década de 1940. Todavia, já em 1936, Alan M. Turing teorizou a respeito de uma máquina executora de operações computacionais ao se referir à teoria dos números ${ }^{16}$, com um sistema formal embutido.

A percepção genial de Turing foi a substituição da noção intuitiva de procedimento efetivo por uma ideia formal, matemática. O resultado foi a

\footnotetext{
${ }^{14}$ Matemático, criptoanalista e cientista da computação britânico.

${ }^{15}$ Matemático alemão, membro estrangeiro da Royal Society of London for the Improvement of Natural Knowledge da Inglaterra, entidade destinada à promoção do estudo científico.

${ }^{16}$ Ramo da matemática que estuda as propriedades dos números.
} 
construção de uma conceituação matemática da noção de algoritmo ${ }^{17}$, uma noção que ele modelou baseando-se nos passos que um ser humano dá quando executa um determinado cálculo ou cômputo. Ele formalizou definitivamente o conceito de algoritmo. [...] $O$ trabalho de Turing ficou documentado no artigo On Computable Numbers with an aplication to the Entscheidungs problem, publicado em 1936 (FONSECA FILHO, 2007, Pg 74).

A teórica Máquina de Turing (como ficou conhecida) provou que qualquer sistema formal pode ser reproduzido por um dispositivo computacional programado para imitá-lo. O modelo previa o processamento de complicadas linguagens e o cálculo de funções aritméticas não triviais.

Nos anos 40 (durante a Segunda Guerra Mundial), Turing foi convocado pelo governo inglês na Escola de Cifras e Códigos para auxiliar a decifrar códigos alemães ${ }^{18}$ e, até o fim da guerra, contribuiu na construção do Colossus Mark 1 ${ }^{19}$ (que decodificou mensagens que auxiliaram no Dia D), um computador (no sentido moderno do termo) com memória e processamento de informações que se assemelhavam aos estados da mente. Em seu artigo Computing Machinery and Intelligence (1950), discorre sobre a possibilidade da construção de uma máquina que imitasse o cérebro humano, uma máquina de pensar.

O primeiro computador de uso geral, o ENIAC (Eletronic Numeral Integrator and Computer ${ }^{20}$, foi construído nos Estados Unidos em 1943, na Universidade da Pensilvânia (Filadélfia/EUA). Entre os principais membros da equipe do projeto estão: J. Presper Eckert ${ }^{21}$ (1919-1995), John Mauchly ${ }^{22}$ (1907-1980) e Herman H. Goldstine $^{23}(1913-2004)$.

17 Algoritmo (Dicionário Michaelis) Conjunto de regras, operações e procedimentos, definidos e ordenados usados na solução de um problema, ou de classe de problemas, em um número finito de etapas.

18 Junto com sua equipe criou o Bombe, uma máquina que conseguia descriptografar os códigos gerados pela máquina "Enigma" alemã.

1919 O Colossus foi um projeto secreto, logo seus idealizadores não receberam crédito e sua tecnologia só foi publicada em 1970.

20 Possuía 17.468 válvulas, pesava 30 toneladas, seu design era em formato de "U".

21 Engenheiro americano.

22 Físico americano.

23 Matemático americano. 


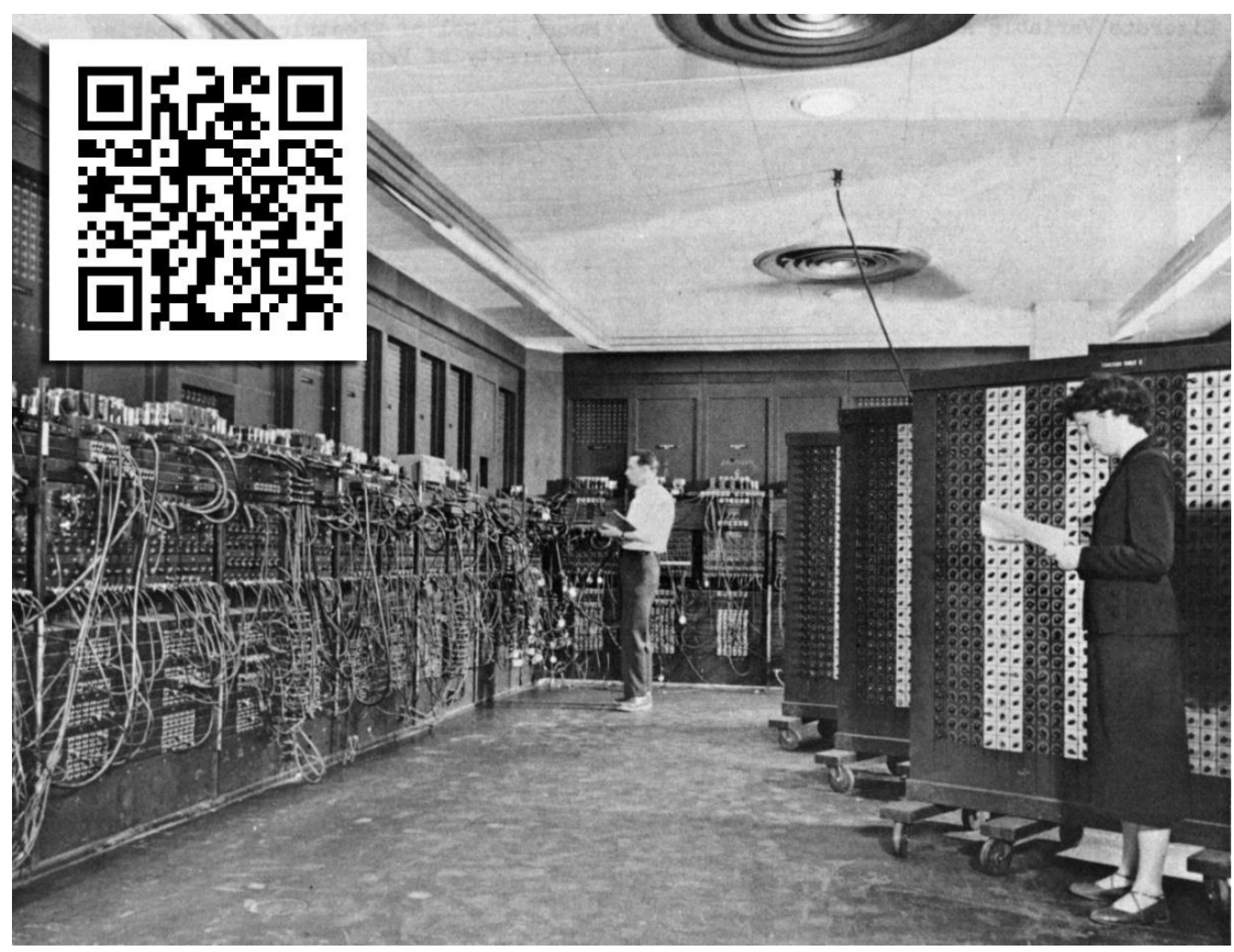

Figura 1: ENIAC (Electronic Numerical Integrator and Computer) na Filadélfia (EUA). Glen Beck (ao fundo) e Betty Snyder (à frente) programando o computador. Através do QR Code é possível assistir a um vídeo da Universidade da Pensilvânia sobre o ENIAC.

Fonte: https://commons.wikimedia.org/w/index.php?curid=55124 Acesso: 21/07/2017.

John von Newmann ${ }^{24}(1903-1957)$, que ingressou na equipe da Universidade da Pensilvânia em 1944, foi fundamental para os estudos de computação dos 40 anos seguintes. Seu trabalho ficou conhecido como "arquitetura de Von Newmann". Um dos conceitos discorridos no estudo foi o armazenamento de programas em forma de números ${ }^{25}$.

O sucessor do ENIAC, O EDVAC (Eletronic Discrete Variable Automatic Computer) foi concluído em 1952. Diferente de seu antecessor, que utilizava números decimais, este aplicava códigos binários para manter os programas gravados na memória.

Nesta primeira fase da criação dos computadores (que neste momento são usados principalmente para cálculos e decodificação), foram essenciais os

\footnotetext{
${ }^{24}$ Matemático e físico húngaro-americano.

${ }^{25}$ Essas teorias foram publicadas em 1945 no artigo First Draft of a Report the EDIVAC.
} 
desenvolvimentos tecnológicos visando à memória e velocidade de processamento. As máquinas podiam ser paradas e reprogramadas a qualquer momento e tornaramse cada vez mais rápidas e confiáveis.

Em 1951, o primeiro computador disponível comercialmente a chamar a atenção do público ${ }^{26}$ foi o UNIVAC 1 (Universal Automatic Calculator - fabricado pela Remington Rand $^{27}$ ). A primeira unidade foi entregue ao Censo americano, mas companhias de seguros e militares tornaram-se grandes clientes.

$\mathrm{Na}$ área de entretenimento, um dos primeiros jogos da história foi criado por Alexander Douglas ${ }^{28}$ (1921-2010): o OXO para EDSAC ${ }^{29}$ (Eletronic Delay Storage Automatic Caculator), uma versão de Tic-Tac-Toe (conhecido como Jogo da Velha no Brasil). O programador Arthur Samuels (1901-1990), em 1952, utilizou o 701 da $\mathrm{IBM}^{30}$ (conhecido como calculadora de defesa) para criar o primeiro programa de computador para jogar damas. Esse programa é fundamental, pois é provavelmente o primeiro de autoaprendizagem, que precede os estudos de Inteligência Artificial (Al).

\subsubsection{Os microcomputadores e os computadores pessoais}

Desde a primeira geração de máquinas computacionais, cada vez mais cientistas se dedicam à melhoria dos computadores. Empresas como a IBM, Intel, Xerox, além das universidades, também participam das pesquisas para criar máquinas cada vez mais rápidas, com maior poder de armazenamento de menor tamanho.

Nos anos 70, surgiram os supercomputadores. Esses não precisavam esperar uma tarefa terminar para iniciar outra; seu sistema de processamento começou a ser fragmentado e a trabalhar com mais de um conjunto de dados ao mesmo tempo.

\footnotetext{
${ }^{26}$ Ao prever o resultado da eleição presidencial dos EUA de 1952 entre Dwight D. Eisenhower e Adlai Stevenson.

${ }^{27}$ Empresa que fabricava equipamentos de escritório, pioneira na fabricação de computadores.

${ }^{28}$ Professor de Ciência da Computação, porém, na criação do jogo, ainda era candidato à Universidade de Cambridge.

${ }^{29}$ Inspirado no EDVAC, criado pelo cientista da computação inglês Maurice Wikes (1913-2010) na Universidade de Cambridge.

${ }^{30}$ Até esse momento, a IBM produzia calculadoras.
} 
A máquina inspiradora dos computadores compactos que posteriormente serão lançados pelas corporações e consumidos pelo usuário comum é o "Alto" da Xerox, de 1974. Seu sistema operacional utiliza uma interface ${ }^{31}$ gráfica usando janelas, ícones e mouse (Interface que será utilizada pelo Lisa da Apple e depois pelo Windows da Microsoft). O "Alto" possuía um processador de texto, um programa de pintura e um editor de gráficos, além de compartilhar arquivos e imprimir documentos em uma impressora a laser, a Xerox.

Em 1975 chega a era dos microcomputadores, uma revolução na área que leva o computador ao uso doméstico. Sua fagulha veio do computador chamado MITS $^{32}$ Altair 8800. A máquina inventada por Ed Roberts ${ }^{33}$ (1941-2010) foi construída com base na tecnologia de chips Intel e vendida como um kit para amadores pela revista americana Popular Eletronics. O sucesso surpreendeu a revista e vendeu 4.000 unidades nos três primeiros meses.

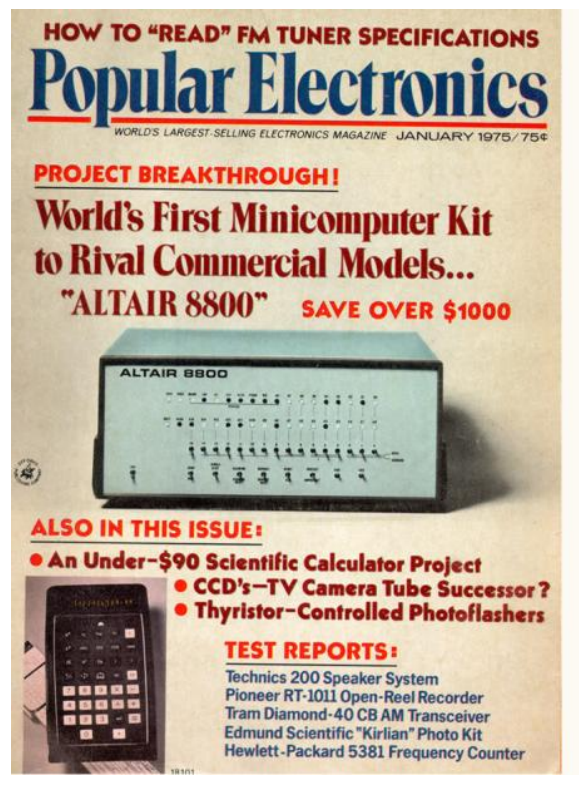

\section{MITS}

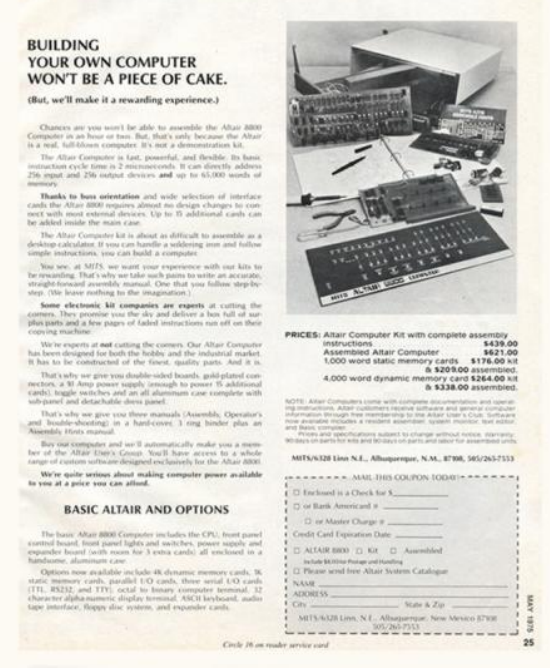

Figura 2: Capa da revista "Popular Electronics" e um anúncio do kit do Altair 8800. Fonte: http://www.hardware.com.br/guias/historia-informatica/altair.html. Acesso em 01/09/2017.

\footnotetext{
${ }^{31}$ Interface tem muitas definições. Aqui se aplica, segundo o Michaelis: "Circuito, dispositivo ou porta que permite que duas ou mais unidades incompatíveis sejam interligadas num sistema padrão de comunicação, permitindo que se transfiram dados entre eles".

${ }^{32}$ Micro Instrumentation and Telemetry Sistems - empresa fundada por Ed Roberts.

${ }^{33}$ Henry Edward Roberts - Engenheiro americano.
} 
Foi quando Paul Allen (1953-) e Willian Gates (1955-) se associaram para escrever uma linguagem computacional (interface) popular para Altair, o Basic. Posteriormente ambos seriam os fundadores da Microsoft. Em 1990 foi considerada a empresa de softwares mais bem sucedida na história dos microcomputadores. (FONSECA FILHO, 2007, Pg 130).

Steve Jobs (1955-2011) e Stephen Wozniac (1950-) fundaram a APPLE em 1976. Wozniac projetou, no mesmo ano, seu protótipo, Apple-1, e Jobs cuidou de sua comercialização. Cerca de 200 placas foram vendidas e, a seguir, a dupla anunciou o Apple 2 (1977), que estaria pronto para o uso do consumidor final.

Mas foi nos anos 80 que a IBM popularizou de forma definitiva o computador doméstico com o lançamento do IBM PC (Personal Computer), uma máquina de arquitetura aberta, que seleciona componentes básicos para sua construção fora da empresa. A década também foi marcada por melhorias em diversos softwares.

Nos anos 90, a computação já era um fenômeno consagrado. Cada vez mais eficientes e com maior memória, os microcomputadores têm uma seleção de funções muito maior do que seus ancestrais, que apenas calculavam. Edição de textos, artes gráficas, comunicação (com a internet), editores de tabelas, enfim, milhares de softwares criados para necessidade de diversas funções diferentes.

A redução notável de tamanho - de salas inteiras para mesas, seguido de notebooks portáteis até o smartfone -, a velocidade e a capacidade de realizar multitarefas parecem ficção, se comparadas às características das primeiras máquinas. $\mathrm{E}$, atualmente o computador é uma tecnologia ubíqua no cotidiano de muitas pessoas.

\subsection{A internet e a World Wide Web}

A ideia de interligar muitos computadores em uma rede também foi idealizada dentro da universidade. Em 1962, no MIT (Massachussetts Institute o Technology) havia uma série de experimentos ocorrendo na tecnologia computacional. Nesse mesmo ano, o professor da instituição, J. C. R. Licklider ${ }^{34}$ (1915-1990) mostra-se

\footnotetext{
${ }^{34}$ Joseph Carl Licklider Robnett, psicólogo e cientista da computação.
} 
visionário ao escrever seu conceito de Rede Intergaláctica, que ligaria as pessoas através do planeta, e possibilitaria o acesso à informação de qualquer lugar do mundo. Esse pensamento prevê o que seria a internet antes mesmo dela ser criada.

Nesse período o SAGE (Semi-Automatic Groud Environment - implantado em 1958), já ligava computadores de larga escala nos Estados Unidos para identificar objetos em movimento em radares, por meio de um sistema de alarme precoce. Em 1958, o governo americano criou a ARPA (Avanced Reserch Project Agency) logo após o lançamento do Sputnik ${ }^{35}$ da União Soviética (seguindo a corrida tecnológica da Guerra Fria).

Nos meados dos anos 60 , os pesquisadores Larry Roberts ${ }^{36}$ (1937-) e Thomas Marill ${ }^{37}$ utilizam a rede telefônica para conectar computadores: o TX-2, do Laboratório Lincon, no MIT (Massachusetts Intitute of Technology) em Cambridge, Massachusetts/EUA ao AN/FSQ-32 SAGE Solid State Computer em Santa Mônica, Califórnia/EUA. Esse experimento confirma a teoria da Rede Intergaláctica de Licklider. Roberts inicia em 1967, pela ARPA, o desenvolvimento da ARPANET (Advanced Research Projects Agency Network), implantada em 1969, ligando as universidades UCLA (University of California, Los Angeles/EUA), Stanford (no Augmentation Reserch Center, Santdford, Califórnia/EUA), UCSB (University of Califórnia, Santa Barbara/EUA) e Utah School of Computing (em Salt Lake City, Utah/EUA). Na década de 70, o sistema cresce cada vez mais; em 1973, chegam a 30 as instituições conectadas. Nos anos 80 , a ARPANET implanta a primeira rede com os sistemas: Protocolo de Controle de Transmissão (TCP) e Protocolo de Internet $(\mathrm{IP})^{38}$.

Muitos foram os cientistas que trabalharam em conjunto com Roberts na ARPANET, que, com o passar do tempo, agregou rede de satélites, rádio e outras networks, evoluindo assim para a internet. Entretanto, conflitos de programas e tipos diferentes de computadores ainda dificultavam o compartilhamento de informações.

\footnotetext{
${ }^{35}$ Primeiro satélite artificial lançado em 1957 pela URSS.

${ }^{36}$ Lawrence G. Robetss, cientista da computação.

${ }^{37}$ Thomas Marill: Psicólogo. Não foi localizada a data de nascimento ou falecimento.

${ }^{38}$ Esses pacotes fornecem comunicação de dados ponta a ponta, organizados em quatro camadas de abstração: a camada de ligação (link), a camada de internet (que, através de portais, roteia pacotes de informações), a camada de transporte (gerenciadora da comunicação) e a camada de aplicação (fornecedora da troca de dados para aplicativos).
} 
Nos anos 90, o engenheiro inglês Tim-Berners Lee (1955-), auxiliado por Robert Cailliau (1947-) apresentou a solução ${ }^{39}$, criando três tecnologias fundamentais para a internet:

- HTML: HyperText Markup Language. Linguagem de estruturação para a web.

- URI: Uniform Resource Identifier. Um endereço que é único para identificar os recursos da web.

- HTTP: protocolo de transferência de hipertexto. Permite vínculos em toda a Web.

Tim-Berners Lee também criou o primeiro editor/navegador de páginas para internet, o World Wide Web.app e o primeiro servidor ("httpd") - o autor assegurou à sua empregadora (CERN) que esses sistemas deveriam ser livres de royalties.

Em 1993, graças ao navegador gráfico "Mosaic" simplificada e, desta forma, o correio eletrônico e as páginas da Web ficaram acessíveis a todos que tivessem uma ligação à rede. A arte rapidamente assimilou este meio. Já em 1994, os primeiros grupos de net art (jodi.org ${ }^{41}$, por exemplo) surgiam e a produção e a circulação do objeto artístico tomou uma nova perspectiva. A internet popularizada é importantíssima a para transmídia digital, pois é nela que os meios de comunicação em massa convergem e é através dela que o objeto artístico pode ser acessível e interativo para milhares de pessoas.

A conexão, que a princípio se fazia entre computadores, atualmente existe entre celulares, tablets e outros dispositivos. Pode-se controlar desde câmeras ou sensores de segurança até o conteúdo de uma geladeira através dos dispositivos conectados pela Web (computador, celular, tablet). Essa conexão de objetos físicos como veículos, eletrodomésticos, centros de logística a outros com a mesma tecnologia embarcada (sensores de conexão que transmitem e recebem dados)

\footnotetext{
${ }^{39}$ Que foi apresentada em 1989 ao seu chefe na CERN (Conseil Européen pour la Recherche Nucléaire).

${ }^{40}$ Desenvolvido no National Center for Supercomputing Applications, EUA.

${ }^{41}$ Coletivo composto pelo artista holandês Joan Heemskerk (1968-) e o artista belga Dirk Paesmans (1965-).
} 
ficou conhecida como 'Internet das Coisas' (conhecido pela sigla loT do inglês Internet of things) ${ }^{42}$.

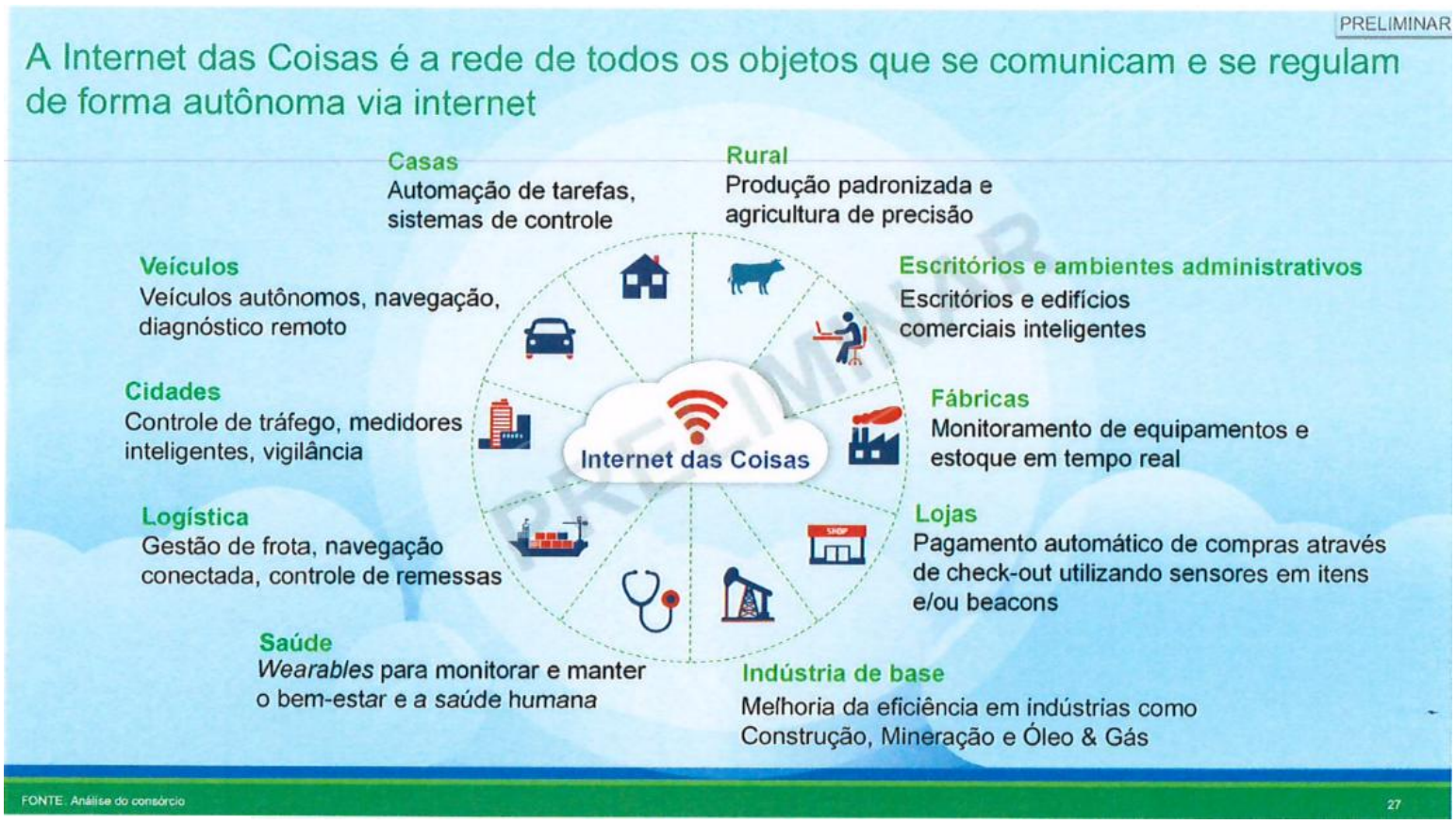

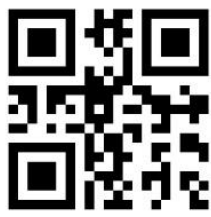

Figura 3 : Infográfico explicativo - loT. Esse infográfico faz parte da matéria de MARQUES, que discorre sobre o investimento do governo brasileiro no 'Plano Nacional da Internet das Coisas'. ${ }^{43}$ No QR code abaixo é possível assistir a um vídeo institucional da Telefônica que explica a loT.

O problema desse sistema consiste em não existir ainda uma linguagem universal que ligue todas essas máquinas através do globo. Buscando uma solução, surge a "Web das Coisas", que propõe a reutilização de linguagens já criadas (protocolos e padrões), para promover maior acessibilidade de dados e serviços a desenvolvedores aplicativos e softwares, gerando, paulatinamente, uma interação mais fácil, rápida e barata entre usuários.

A terminologia é criada a partir das necessidades percebidas no dia a dia do uso da tecnologia. Enquanto isso, a conexão de pessoas através da internet cresce.

\footnotetext{
${ }^{42}$ Conexão de objetos cotidianos (como eletrodomésticos) através da internet. O termo surge em 1999 por Kevin Ashton do MIT.

${ }^{43}$ Matéria completa disponível em: https://www.poder360.com.br/governo/governo-lancara-planonacional-de-internet-das-coisas-no-2o-semestre/ Acesso em 10/12/2017.
} 
Muito mais que informação, produtos ou serviços, o acesso a Web, tanto por computadores como a partir de dispositivos móveis, torna-se visceral na convivência e comunicação social do homem.

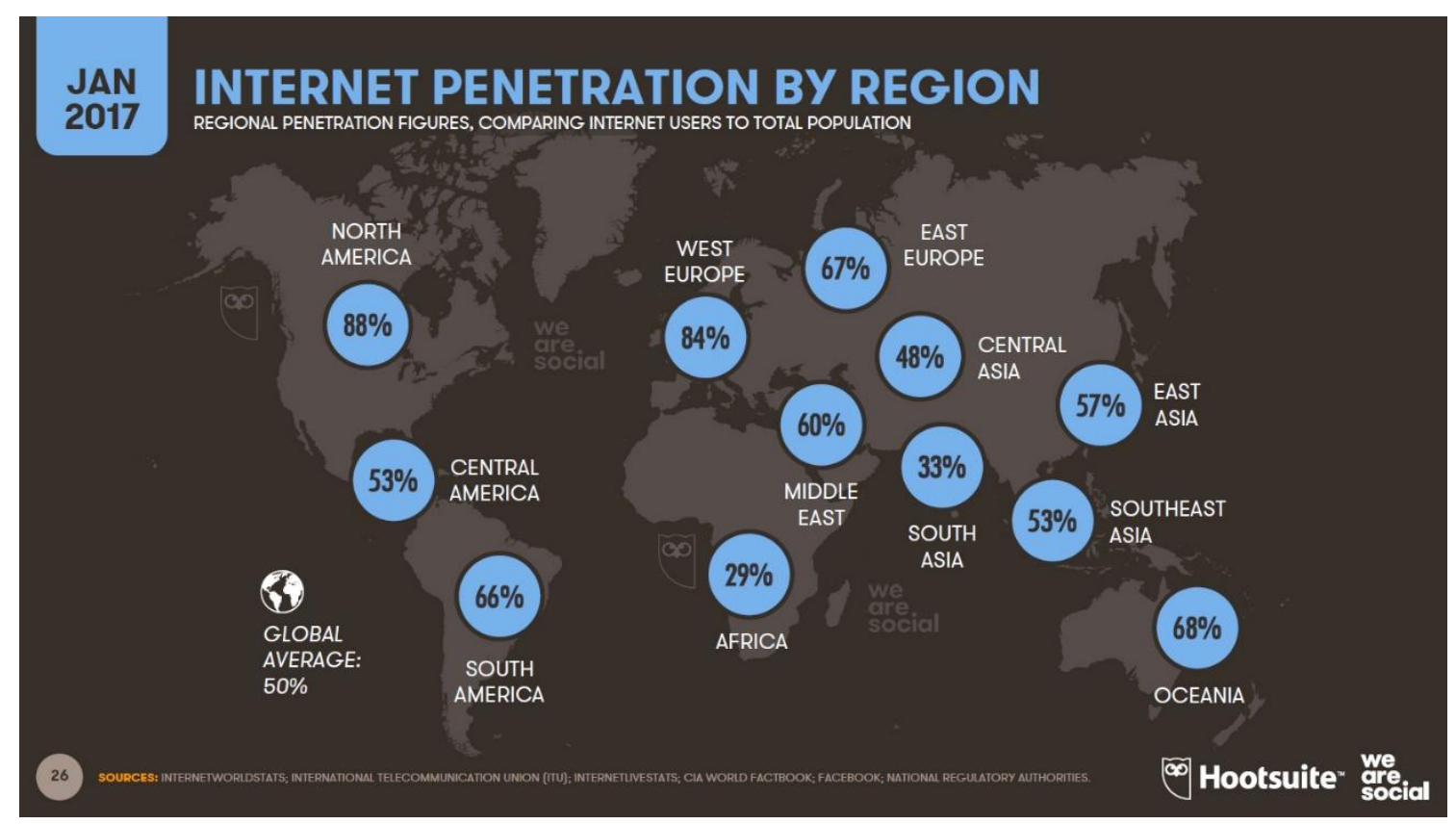

Figura 4: Penetração da internet por região. Dados coletados por KEMP, Simon (2017) com base em: Internetworldstats; International Telecommunication Union (ITU); Internetlivestats; Cia World Factbook; Facebook; National Regulatory Authorities. Fonte: https://www.slideshare.net/wearesocialsg/digital-in2017-global-overview?from action=save Acesso em 10/12/2017. 


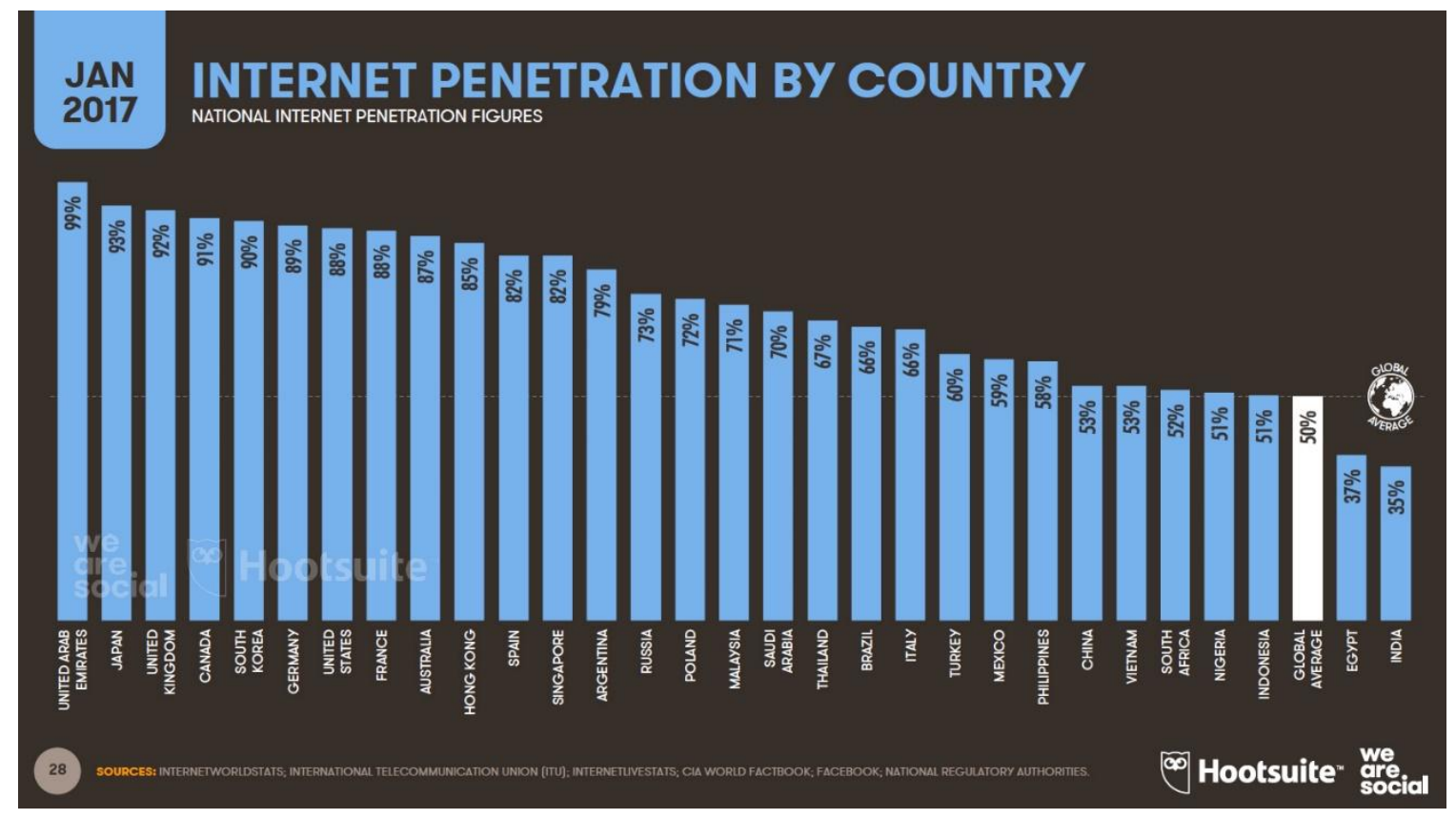

Figura 5: Penetração da internet por país. Dados coletados por KEMP, Simon (2017) com base em: Internetworldstats; International Telecommunication Union (ITU); Internetlivestats; Cia World Factbook; Facebook; National Regulatory Authorities. Fonte: https://www.slideshare.net/wearesocialsg/digital-in2017-global-overview?from action=save

Acesso em 10/12/2017.

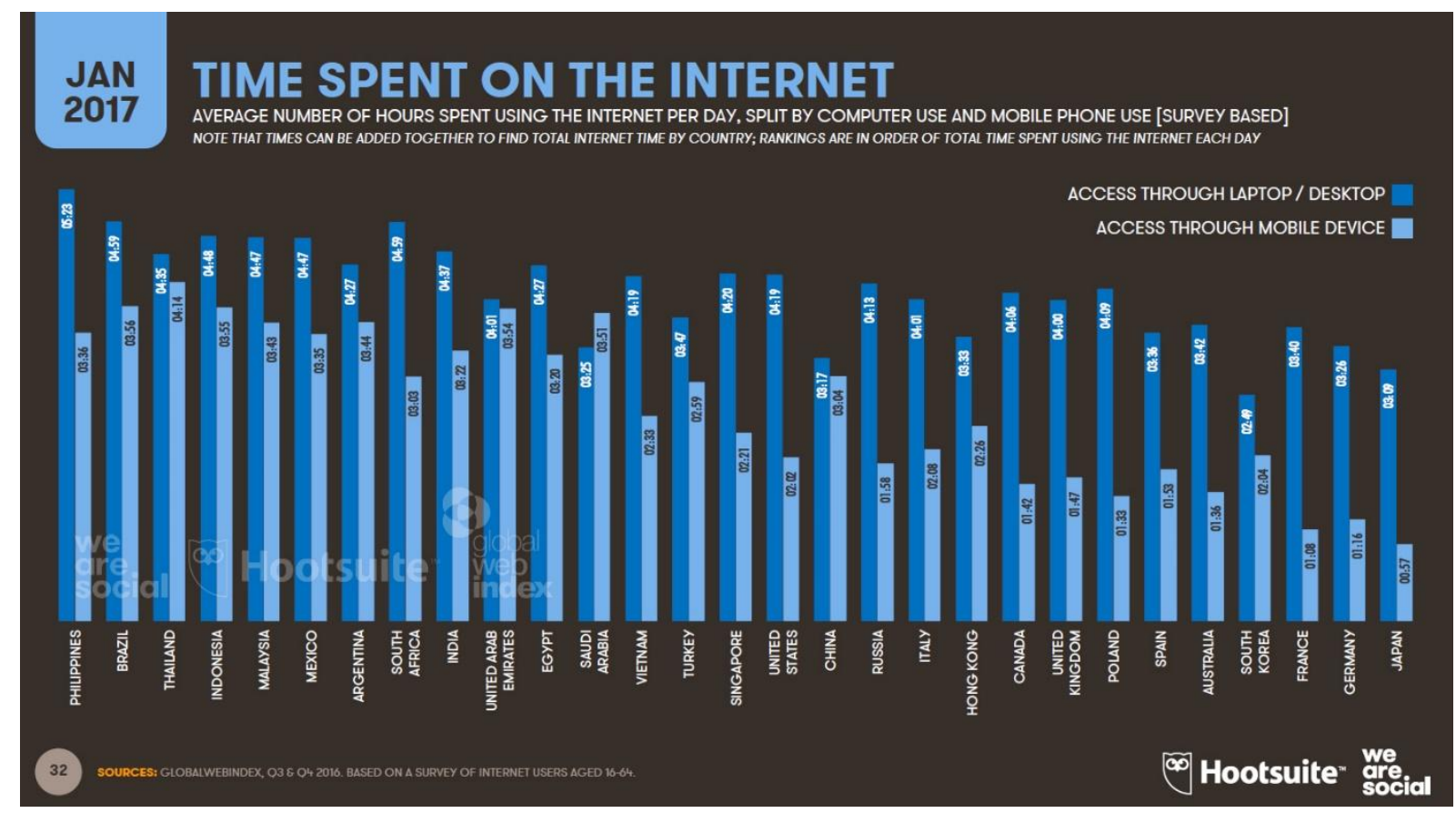

Figura 6: Tempo gasto na internet por país. Dados coletados por KEMP, Simon (2017) com base em: Internetworldstats; International Telecommunication Union (ITU); Internetlivestats; Cia World Factbook; Facebook; National Regulatory Authorities. Fonte: https://www.slideshare.net/wearesocialsg/digital-in2017-global-overview?from action=save. Acesso em 10/12/2017. 
Para compreender a afirmação acima, basta analisar algumas pesquisas da penetração da Web através do globo (figuras 4,5 e 6). Na maior parte das regiões, $50 \%$ ou mais da população tem acesso à internet, dispendendo de três a quatro horas ao dia on-line. O número de pessoas conectadas nas regiões mais desenvolvidas é impressionante, mas também é bastante expressivo em regiões menos abastadas como a América Central (53\%), a Ásia Central (48\%) e a América do Sul (63\%).

A partir dessa grande mudança de paradigma da conexão humana, filósofos e sociólogos se dividem ao discutir a respeito da influência do fator tecnológico no comportamento:

De um lado, alguns reivindicam que não há consequências do uso do computador em si, pelo menos não mais do que há com o letramento (incluindo o visual e o computacional). Somente há consequências para indivíduos que usam essas ferramentas. De outro lado, há aqueles - tão diferentes entre si como Goody e Kittler - que sugerem que o uso de um novo meio de comunicação inevitavelmente muda a longo prazo, se não antes, a visão das pessoas sobre o mundo. Uma corrente acusa a outra de tratar pessoas comuns como passivas, objetos do impacto do letramento ou da computação. A acusação inversa é tratar a mídia, inclusive a imprensa, como passiva, espelho da cultura e da sociedade, e não como agência de comunicação, transformando tanto uma quanto outra. (BRIGGS e BURKE, 2006, pg. 26)

A maior parte das pessoas utiliza a tecnologia como usuário, sem compreender como seus dados circulam na internet, ou como os algoritmos podem limitar sua experiência, tornando-se mediadores de informação. Seja como for, o debate permanece, acumulando a cada dia mais dados a serem analisados sobre uma revolução tecnológica que ainda não completou 100 anos.

\subsubsection{Web 1.0, Web 2.0 e Web 3.0}

A internet é ferramenta importante para a transmídia digital, principalmente a partir do momento em que se torna mais interativa, rápida (banda larga) e acessível (não só pela possibilidade do acesso, mas pela simplificação das interfaces). Apesar da terminologia, a Web de 1.0 a 3.0 não se refere apenas a 
avanços tecnológicos, mas também a aspectos estruturais, de interface e sociológicos vinculados à rede. Essa separação é feita a partir da análise do projeto "WWW' desde sua criação até os tempos atuais:

Identificamos três qualidades da World Wide Web, nomeadamente Web 1.0, Web 2.0 e Web 3.0. Utilizamos os termos Web 1.0, Web 2.0, Web 3.0 não em um sentido técnico, mas para descrever e caracterizar a dinâmica social e os processos de informação que fazem parte da Internet. Essas noções baseiam-se na ideia de conhecimento como um processo dinâmico triplo de cognição, comunicação e cooperação. (FUCHS, Et al, 2010)

A Web 1.0 surge junto com a primeira conexão de computadores. É considerada estática (com pouca interatividade); os usuários em geral apenas a consumiam e nunca criavam conteúdos.

Já a Web 2.0 aplica uma série de novas tecnologias para permitir a interatividade do usuário e está relacionada à grande proliferação da comunicação - redes sociais, chats, bogs, vlogs, etc. Na web 2.0, o usuário produz conteúdos próprios e facilmente o publica para outros usuários.

Frequentemente é complexo distinguir a Web 1.0 da 2.0. Isso se deve ao fato de muitos sites sofrerem transição de uma para outra, agregando recursos ao longo do tempo. O termo Web 2.0 foi cunhado em 2004, porém, os primeiros sites interativos começaram a surgir já em 2003. Páginas de perfil completas (com idade, sexo, localização e comentários do usuário, etc.), conexões entre usuários (formando comunidades ou grupos de amigos), ampla possibilidade de publicar conteúdos (fotos, vídeos, textos em blogs), avaliar e comentar publicações de outros usuários e controle de privacidade são alguns exemplos de recursos da Web 2.0. (COMORDE e KRISHNAMURTHY, 2008).

A Web 3.0, uma extensão das anteriores, foi idealizada por Tim-Berners ao deixar a Organização Europeia para Pesquisa Nuclear (CERN) em 1994 e fundar a W3C $^{44}$ (Consórcio World Wide Web), um consórcio internacional e organizações filiadas, que fomentam a compatibilidade de padrões para internet tornando-a cada vez mais acessível a diferentes hardwares (computadores, celulares, tablets) e

\footnotetext{
${ }^{44} \mathrm{http}: / /$ www.w3c.br
} 
softwares (browsers). A "Web semântica" (ou Web 3.0) é o nome desse projeto de acessibilidade da W3C (DECKER et al., 2000 \& BERNERS-LEE et al., 1999 in ALVARENGA e SOUZA, 2004) que estabelece relações entre signos e a realidade, ou seja, associa documentos e seus significados através de metainformações (ou metadados) ${ }^{45}$ descritivas (os), facilitadores da compreensão de utilidade e racionamento entre informações (ou dados). Também chamada de "Web inteligente", a Web 3.0 define valor e significados, catalogando e organizando a informação, tornando-a mais propensa a ser acessada.

\subsubsection{Mídias Sociais}

As origens da mídia social são objeto controverso, mas antes do primeiro site reconhecido e devotado para comunicação digital (o SixDegrees, em 1997), os programadores Randy Suess e Ward Christensen (1945-) criaram o CBBS, o primeiro Bulletin Board System: um sistema digital que permite a conexão entre duas ou mais pessoas através de linhas telefônicas.

A intenção dos programadores era permitir que especialistas e entusiastas em computação trocassem informações, divulgassem mensagens públicas e compartilhassem arquivos num ambiente digital - um objetivo praticamente igual (ainda que com intenções distintas) dos grandes sites de mídia social de hoje.

O SixDegrees foi de fato o primeiro site do gênero a disponibilizar um software com criação de perfis virtuais e criar um sistema de "Teia de Contatos" em que, através dos perfis digitais daqueles que se adicionam à sua conta, um indivíduo consegue alcançar os contatos daqueles a quem subscreve. Sua existência foi relativamente curta, tendo suas atividades encerradas em 2001, inviabilizado por uma propagação descontrolada de $\operatorname{SPAM}^{46}$ (propagandas).

Nos anos 2000, aproximadamente 361 milhões de pessoas já tinham acesso frequente à internet ${ }^{47}$. Plataformas para conversas digitais, fóruns e envio de arquivos dispunham de uma grande base de usuários. A verdadeira explosão de

\footnotetext{
${ }^{45}$ Metainformação - informações sobre informações.

${ }^{46}$ Sending and Posting Advertisement in Mass - postar e enviar propaganda em massa pela internet.

${ }^{47}$ Estatísticas de Internet World Stats em http://www.internetworldstats.com/emarketing.htm.
} 
popularidade das redes sociais ocorreu com o lançamento do Linkedln (2002) e do MySpace (2003); logo depois surgiram os sites que realmente tornaram usual a comunicação através das mídias sociais: Facebook (2004) e Twitter (2006).

Com o passar dos anos, surgiram ainda redes sociais para objetivos e culturas específicas (como o Flickr, especializado em fotos e vídeos, e o Sina Weibo, direcionado exclusivamente para o povo chinês, sob a supervisão do governo chinês).

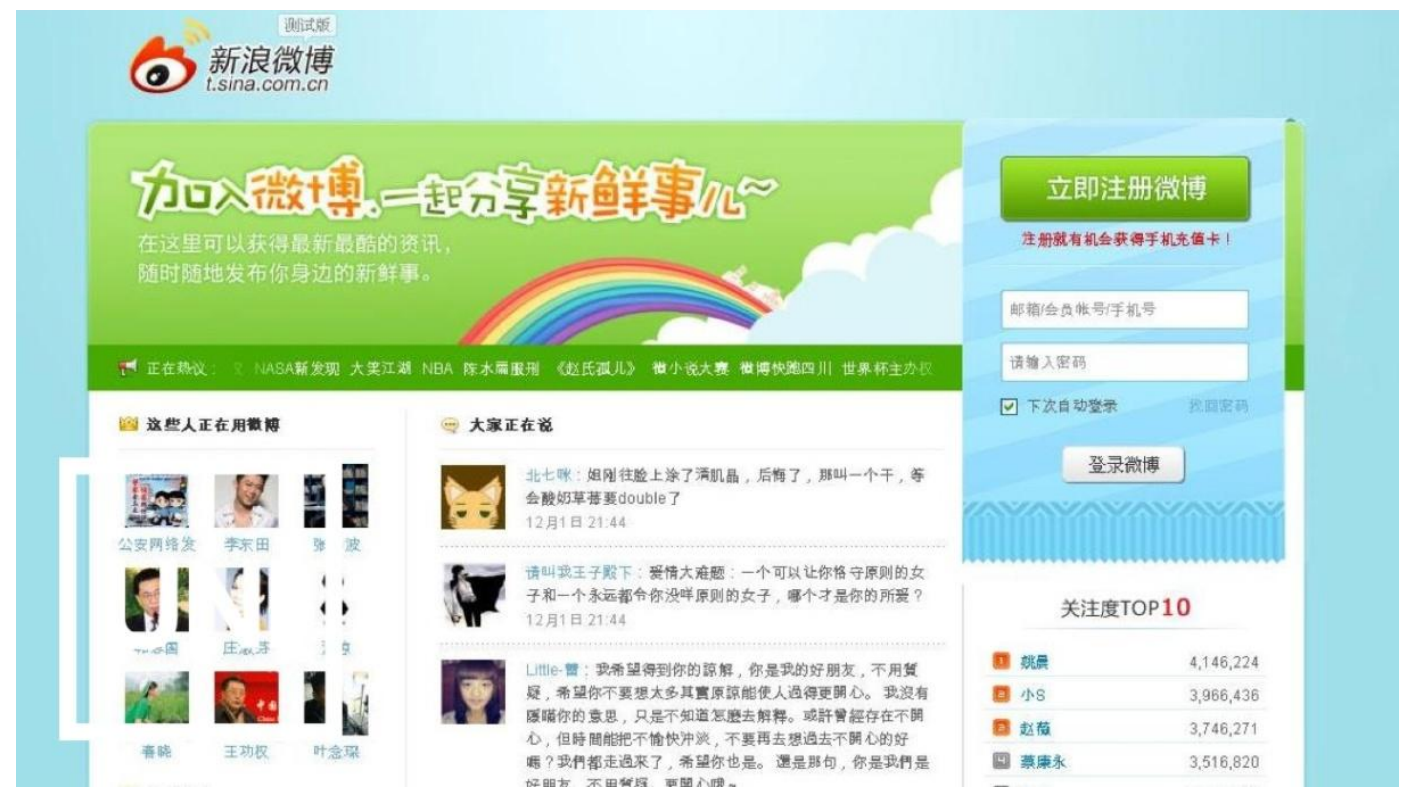

Figura 7: Sina Weibo, o Twitter chinês. Fonte: https://i.ytimg.com/vi/Fc3N1eBM44E/maxresdefault.jpg Acesso em: 20/12/2017.

Hoje, praticamente qualquer imagem, texto ou vídeo podem ser compartilhados por qualquer pessoa que disponha de um computador conectado à internet ou um smartphone, possibilitando que a transmídia (tanto artística quanto marqueteira) permeie o universo do usuário em qualquer lugar e em qualquer hora.

A quebra virtual de barreiras geográficas faz com que todo tipo de informação seja difundida quase instantaneamente - desde os vídeos mais populares sobre filhotes de gatos adoráveis, até notícias sobre conflitos no Sudeste Asiático e no Oriente Médio.

Diferente de um aparelho de televisão, as redes sociais permitem que todos os espectadores compartilhem suas opiniões sobre um determinado assunto, acrescentem informações, correções e atualizações a notícias em tempo real e 
trabalhem em conjunto para a divulgação, tradução e popularização do conhecimento e informação.

\subsection{Múltiplas mídias, múltiplos conceitos}

Poucas palavras na língua abrangem tantos significados, sufixos e dúvidas quanto "mídia". Descendente do inglês "media" (mass media, ou mídia de massa), que por sua vez descende do latim "medium" (meio, canal), mídia refere-se, de forma genérica, à forma ou à plataforma em que algum conteúdo é comunicado ou compartilhado.

O termo é utilizado por diversos meios de comunicação, publicidade, entretenimento e arte com sentidos diferentes. Dentro das múltiplas derivações, esta dissertação requer o entendimento de alguns termos e conceitos que utilizam este mesmo radical.

\subsubsection{Da Monomídia à Multimídia}

A monomídia é o ponto de partida para a compreensão dos conceitos tratados a seguir. Trata-se da comunicação através de apenas um canal, em que o criador da mensagem tem o controle do fluxo de informação através da interrupção. (ARNAUT, Rodrigo Dias, et al. 2011).

Multimídia, técnica usual no mundo moderno, é o emprego de vários tipos de mídia num mesmo veículo. Estamos rodeados de canais que lançam mão simultaneamente de imagens estáticas ou em vídeo, sons, textos e outras formas de mídia. (VAUGHAN, 2014).

Dentro deste conceito, pode-se argumentar que a multimídia existe há muito tempo, já que tais combinações, como imagem e áudio (cinema), não são exatamente recentes. Porém, o emprego e sua definição surgiram mais recentemente. O termo foi usado inicialmente nos anos 60, quando as primeiras performances artísticas empregaram atuação, música e imagens de forma complementar e simultânea. 
Hoje é praticamente impossível acessar conteúdo na internet que não possua ao menos dois tipos de mídia. Editores modernos de web design, imagem, sons e texto tornam trivial o processo de criar conteúdos com diversas mídias integradas.

\subsubsection{Crossmídia}

É considerada crossmídia aquela que apresenta (ou divulga) uma mesma notícia ou campanha publicitária através de rádio, televisão e aplicativos de celular, entre outros. Ou o conteúdo de um livro, que foi adaptado em quadrinhos e finalmente transformou-se num filme. Apesar de a conceitualização ser recente, claramente esta forma antecede a definição.

Etimologicamente, neste caso, "cross" significa uma qualidade que abrange mais de um sujeito - como pneus "cross-terrain", que servem para diversos terrenos diferentes. Sucintamente, crossmídia é uma técnica em que se lança mão de várias linguagens e veículos midiáticos para contar uma mesma história. (MICHELSON, 2011).

Esta técnica é eficaz em transmitir diretamente a informação ao seu receptor, mas age de forma repetitiva - afinal, é o mesmo conteúdo que está sendo veiculado em tecnologias distintas.

\subsubsection{Crossmídia aplicada}

Na rápida evolução da linguagem publicitária das últimas décadas, o termo crossmídia foi utilizado para enumerar diversas técnicas. Em sua essência inicial, crossmídia nada mais era do que o emprego de diversas mídias para passar uma mesma mensagem. Claramente, a ideia de contar uma história através de vários canais já era possível com a utilização de jornais, revistas, rádio e televisão, mas a solidificação do termo surgiu com a organização de campanhas de grande porte e abrangência, fruto de coordenação maior e ordenada entre diversas mídias. 

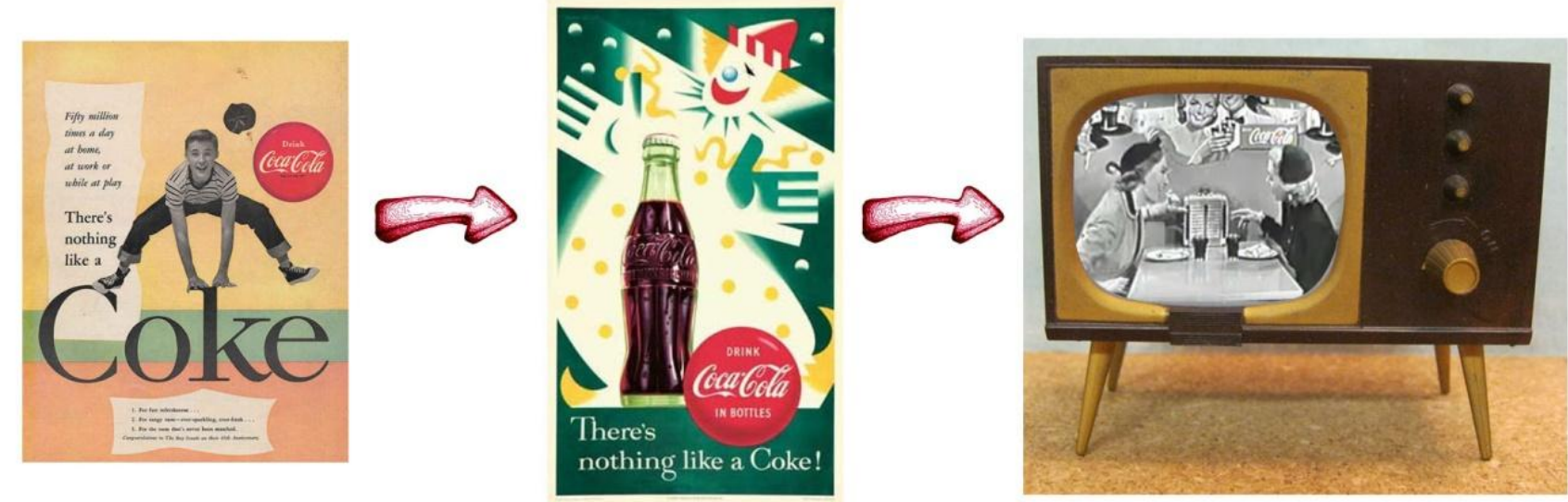

Figura 8: Pode-se usar como exemplo a campanha da Coca Cola de 1953 a 1955, "There's nothing like a Coke", utilizava o mesmo slogan, jingle e linguagem visual em suas propagandas (cartaz, revista e TV).

Nos anos 80 , os avanços tecnológicos e as novas práticas e filosofias de negócios e marketing geraram o embrião teórico do conceito e da técnica de crossmídia. A nascente era digital impulsionou as tecnologias de comunicação e criou um ambiente propício a uma convergência de mídias, utilizada por grandes corporações para produzir campanhas coordenadas e de plataformas diversificadas. Conforme Jenkins (2009) "As novas tecnologias midiáticas possibilitaram que o mesmo conteúdo fluísse por vários canais diferentes e assumisse formas distintas no ponto de recepção". Na área de publicidade e marketing, a crossmedia evolui para a transmídia.

\subsubsection{Intermídia}

Diferente de outros termos relacionados à combinação de mídia, que são utilizados para demonstrar a forma em que tais junções ocorrem em diversos meios de comunicação - seja jornalismo, publicidade, marketing, ou qualquer outro Intermídia refere-se especificamente à combinação de mídias dentro do âmbito artístico.

O termo foi cunhado por Dick Higgins nos anos 60. Higgins era participante do Fluxus, um movimento das décadas de 60 e 70, que promovia a síntese e amálgama de diversas mídias na criação artística. O teatro, as artes visuais, a escultura não 
são suficientes para definir a obra, pois elas foram um conjunto intermediário entre mídias. (HIGGINS, 1965 in HIGGINS, 2001). Ele definiu intermídia da seguinte forma: "a forma de expressão que se situa entre os gêneros existentes, como poesia e música, por exemplo, poema vocal ou poema visual". (HIGGINS in MIEKO, 2013).

Intermedia Chart Dick Higgins

Molvena Italy 19 January, 1995

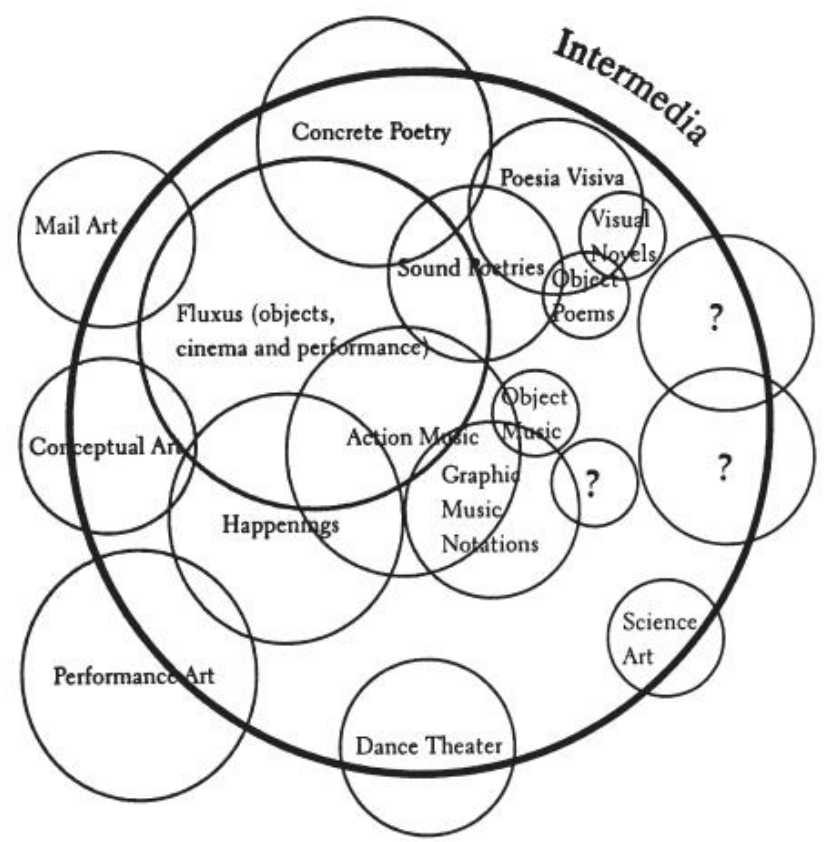

Fig. 1. Intermedia Chart, 1995. (๑ Estate of Dick Higgins) The chart shows concentric and overlapping circles that appear to expand and contract in relationship to the "Intermedia" framework that encompasses them.

Figura 9 Gráfico sobre intermídia de Higgins - 0 gráfico mostra círculos de forma concêntrica, que se sobrepõem e aparentam expandir-se e contrair-se em relação à moldura da "Intermídia" que os engloba. (tradução livre da legenda, HIGGINS, 2001).

Pode-se imaginar, então, que as formas de arte são percebidas como uma linha, ou um fluxo, único e interligado, e cada uma das mídias é um ponto neste fluxo. Tome-se como exemplo o Haiga, uma forma de poesia japonesa onde ilustrações acompanham o texto, o Haikai. O Haiga residiria entre o desenho e a poesia. 


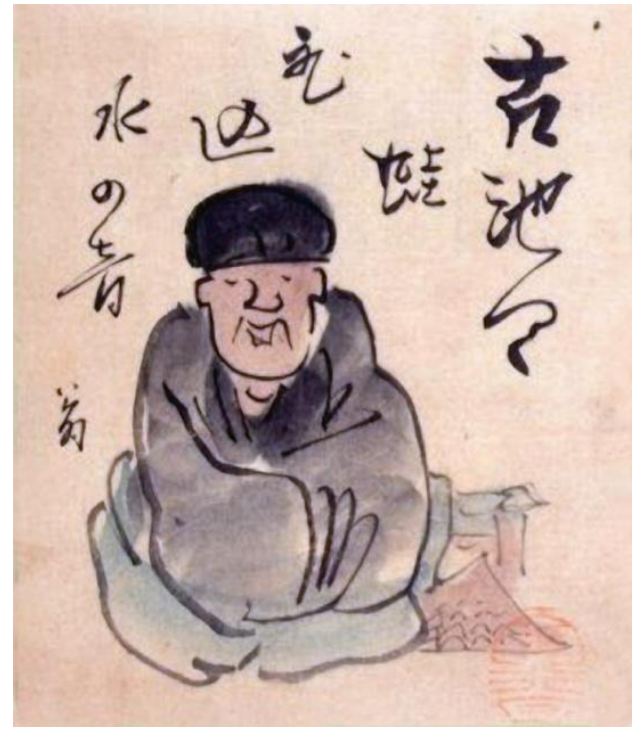

Figura 10: Exemplo de Haiga, retrato e poema de Matsuo Basho pelo artista Yokoi Kinkoku. Era Edo, 1820. Fonte: http://folhadepoesia.blogspot.com.br/2015/01/haiku-um-caminho-pessoal-de.html. Acesso em 18/07/2017.

Este fluxo não é necessariamente linear, já que todos os meios podem se mesclar - como no caso de arte performática envolvendo pintura corporal e dança, ou de uma mistura de grafite de rua e poesia, comumente encontrada nas grandes cidades. A síntese, no que tange à ideia essencial, interconecta todas as mídias, e os "espaços" entre uma mídia e outra - em que as fronteiras se misturam com componentes dos dois lados - também são veículos de expressão artística.

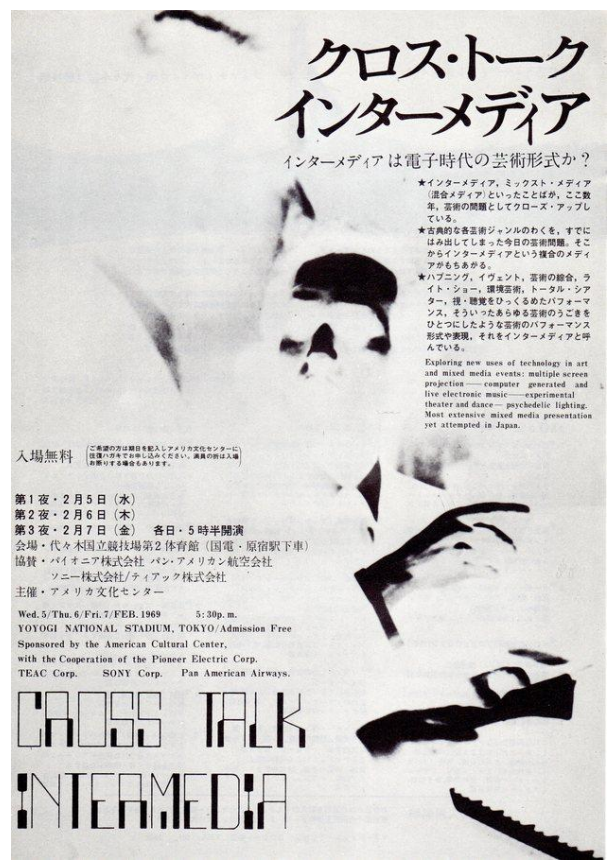

Figura 11: Shiomi Mieko, Sonho Amplificado, década de 60. Disponóvel em: http://post.at.moma.org/content items/241-intermedia-transmedia 


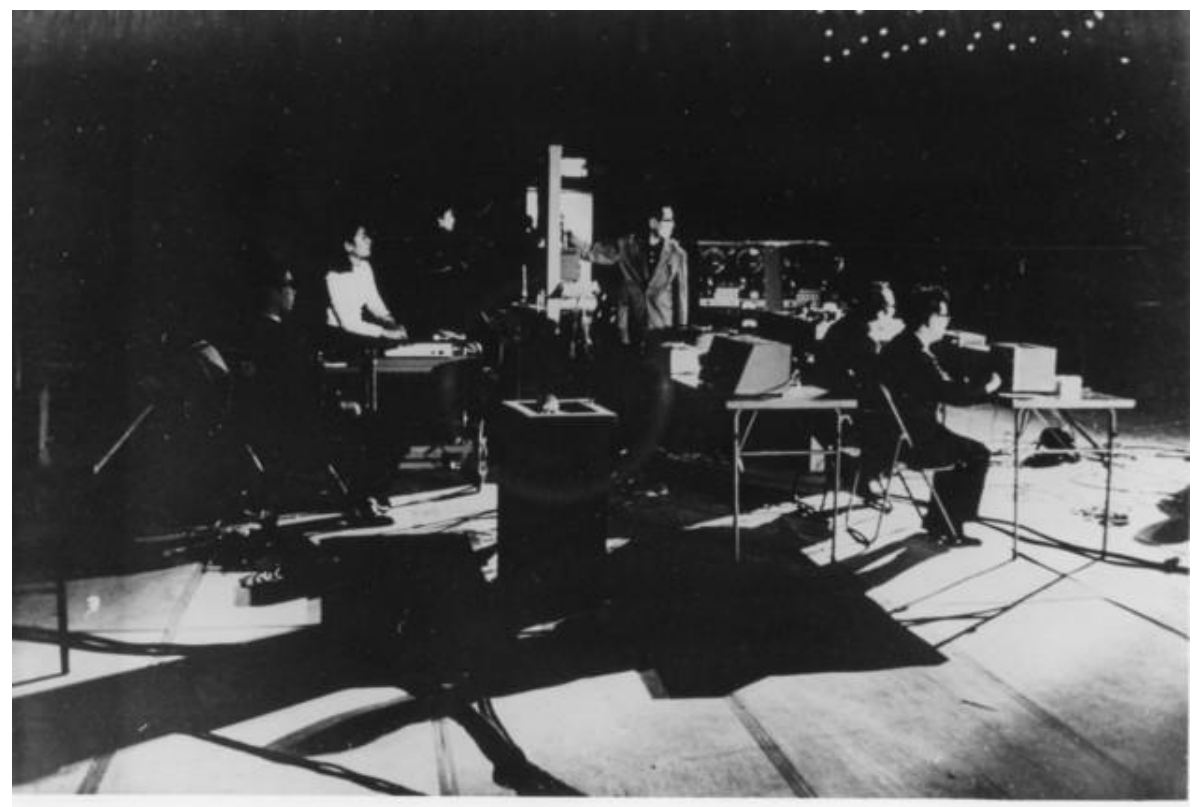

Figura 12 Desempenho do Sonho Amplificado de Shiomi Mieko durante a Intermedia Crosstalk. Disponível em: http://post.at.moma.org/content_items/241-intermedia-transmedia.

A compositora e artista Shiomi Mieko, também integrante do Fluxus, postula que a arte é como um passageiro numa viagem em que se utilizam vários veículos. Segundo Mieko, o embrião temático pode peregrinar por vários meios carregando sua essência mesmo que se altere a mídia. Em meados dos anos 60, MIEKO apresentou nos eventos Intermedia Art Festival (Tókio, 1969) e Cross Talk/Intermedia (evento colaborativo entre EUA e Japão, Tókio, 1969) a obra "Amplified Dream I" (figuras 11 e 12), cujos trabalhos tinham o mesmo título, mas conteúdos diversos, agregando imagem, som e objetos (3 pianos e um moinho de vento).

O que os dois trabalhos tinham em comum era uma estrutura muito bem unida, em parte usando a tecnologia eletrônica, o que permitiu o progresso de todo o evento através do feedback mútuo do som, da luz, do ritmo dos sinais Morse, dos textos projetados e dos movimentos do corpo humano. ${ }^{48}$ Se mesmo um desses elementos estivesse faltando, o todo não teria funcionado. Isto é o que o torna diferente do "multimídia". Naquela época, todas as mídias de igual significado estavam disponíveis

\footnotetext{
${ }^{48}$ Infelizmente não houve registro fotográfico da parte performática.
} 
para mim. A experiência da intermedia tornou-se uma base para que eu mudasse para o próximo passo do transmídia. (MIEKO, 2013)

A citação acima esclarece que a Intermídia, no cenário artístico, foi o degrau que levou Mieko a pensar e trabalhar com arte transmidiática. Também deixa clara a separação entre multimídia e intermídia, já que, para a obra ser compreendida como um todo, necessitava de todos seus recursos.

\subsubsection{Transmídia}

A transmídia, como conceito relativamente novo, ainda tem suas fronteiras a serem definidas. O termo transmídia, criado inicialmente por Henry Jenkins em seu livro "Cultura de Convergência" ${ }^{49}$, define o uso de múltiplas mídias (digitais e analógicas) para transmitirem conteúdos complementares, que podem pertencer a uma mesma narrativa ou não.

Palavras e termos surgem para solucionar problemas de comunicação. Se existe um fenômeno ou inovação dentro de qualquer área, um termo será desenvolvido para nomeá-la. Isso significa que a presença da transmídia precede o próprio uso do termo.

Departamentos, cursos e laboratórios de transmídia estão sendo criados dentro de diversas universidades. A Syracuse University em Nova lorque (EUA) tem um departamento de pesquisa em transmídia ${ }^{50}$, assim como a Sint-Lukas Brussels University College of Art and Design ${ }^{51}$ em Bruxelas (Bélgica) e a Pontifícia Universidade Católica de São Paulo (PUCSP) ${ }^{52}$. Em geral, esses cursos visam à formação de pessoas que possam gerenciar um projeto multiplatafórmico em transmídia storytelling, estudando as interações híbridas ubíquas do cotidiano entre diversas mídias como televisão, cinema, videogames, web, redes sociais, etc.

\footnotetext{
49 JENKINS, Henry. Cultura de Convergência. Editora Aleph, 2009.

${ }^{50}$ O Departamento de Transmídia está disponível em http://vpa.syr.edu/academics/transmedia/ Acesso em 14/07/2016.

${ }^{51}$ Curso de dois anos, que concede o título de mestre. Disponível em http://www.lucaarts.be/en/opleiding/transmedia - Acesso em 14/07/2016.

${ }^{52}$ Curso de pós graduação em Transmídia Storytelling, que tem o objetivo de preparar os alunos no planejamento de projetos transmidiáticos. Disponível em http://www.pucsp.br/posgraduacao/especializacao-e-mba/transmedia-storytelling - Acesso em 14/07/2016.
} 
Também existem grupos de estudos acadêmicos como "\#EraTransmídia”, na ESPM, que procuram estudar as relações humanas a partir do universo multiplatafórmico midiático e o conceito de transmídia na comunicação, separando-o de outros conceitos como multimídia e crossmídia.

O grupo de estudos em transmídia da ESPM, \#EraTransmídia, formatou alguns ítens para conceituar um projeto sobre o assunto:

"Deve partir de um conteúdo principal envolvente; ser distribuído nas múltiplas plataformas de mídia; utilizar o melhor de cada uma delas; gerar interesse, possibilitando visibilidade; manter a atenção e o engajamento das pessoas (compartilhando ou interagindo); permitir que novos conteúdos sejam produzidos (estáticos, audiovisuais, interativos, etc.); obter resultado positivo ou êxito; levar à transversalização, ou seja, tornando-se um fenômeno." ${ }^{53}$

No seminário "Teoria crítica, cultura digital, cinema expandido" no Instituto de Estudos Avançados da USP (2013), a transmídia foi abordada de forma crítica, problematizando o papel do artista na era digital. Um dos convidados, o artista Pedro Paulo Rocha, critica a postura academicista brasileira que cria obstáculos entre a teoria e os movimentos artísticos em relação à criação por meios digitais ${ }^{54}$.

A grande mudança, em parte advinda da proliferação de meios de comunicação nas últimas décadas, é a colaboração das mídias na composição da história. Desenvolvendo os exemplos supracitados, a notícia de uma enchente, no rádio, alerta os motoristas sobre alagamentos em determinados pontos da cidade; o locutor do rádio comunica que os trajetos mais perigosos estão nos aplicativos de mapa e clima da emissora; ao verificar o aplicativo, o usuário vê um anúncio em que as imagens e relatos sobre a inundação serão cobertos em detalhe no jornal da noite.

O que se vê aqui é o uso da técnica de transmídia - uma orquestra de informações onde cada instrumento, é componente da sinfonia, ou história. A

\footnotetext{
${ }^{53}$ ARNAUT, Rodrigo Dias, etal. Era Transmídia. Revista Geminis ano 2, número 2. Pág. 259-275.

${ }^{54}$ LIMA, Juliana Domingos de. Artista transmídia defende quebra de paradigma para aliar crítica $e$ cultura digital. São Paulo. Arte e Cultura - Instituto de Estudos Avançados, Ano 46, Ed. 62, 2013. Disponível em http://www.usp.br/aun/exibir?id=5396 - Acesso em 14/07/2016.
} 
complementação, ou interatividade entre os meios, é a característica central de transmídia.

Considerando a grande quantidade de pessoas que abraçaram (se agarraram?) na transmídia, não devemos nos surpreender que:

1. Diferentes grupos de pessoas estão definindo um conceito emergente de forma diferente para propósitos diferentes e audiências diversas em contextos distintos;

2. Alguns daqueles que falam sobre transmídia são menos inteirados em artigos anteriores e em teorias como gostaríamos, trazendo então certo grau de confusão;

3. Alguns grupos estão fortemente motivados a expandir ou confundir o escopo da categoria para propósitos de autopromoção ou para benefício próprio. ${ }^{55}$

Diferente da crossmídia, em que o conteúdo é propagado em sua integralidade por diversas plataformas, na narrativa transmídia o objeto é disseminado em componentes distintos através de canais que se complementam, ao invés de se repetirem. O resultado é uma narrativa que percorre múltiplas plataformas, dando diferentes perspectivas à experiência do usuário, que procura novas nuances da história contada em cada meio.

Observe-se, como exemplo, o uso da transmídia pela empresa de entretenimento Starlight Runner ${ }^{56}$ para o jogo de cartas Magic: The Gathering. Depois de criado o universo do jogo (World Design - "Corondor on the World of Dominaria") foram criados livros de história, comic books, graphic novels, vídeo games, web sites e adventure games - inúmeras mídias que contam uma única história. ${ }^{57}$ Outro exemplo é a franquia Matrix, onde os bits-chave de informações foram transmitidas através de três filmes de ação ao vivo, uma série de curtas de

\footnotetext{
55 JENKINS, Henry. Transmedia 202: Further Reflexions. 2011. Disponível em http://henryjenkins.org/2011/08/defining transmedia further re.html Acesso em 31/05/2016. ${ }^{56}$ Starlight Runner Entertainment é a maior especialista do mundo em expansão propriedades de entretenimento, marcas premium, e temas sócio-políticos em narrativas transmídia de grande sucesso e campanhas internacionais, Jeff Gomez é CEO da empresa e um dos pioneiros em transmídia.

${ }^{57}$ Starlight Runner, disponível em http://www.starlightrunner.com/magic the gathering. Acesso em 20/11/2014.
} 
animação, duas coleções de histórias em quadrinhos e diversos jogos de video game. Dessa forma, não há uma única fonte onde se podem obter todas as informações necessárias para compreender o universo Matrix ${ }^{58}$.

\section{Transmedia Story: The Matrix}

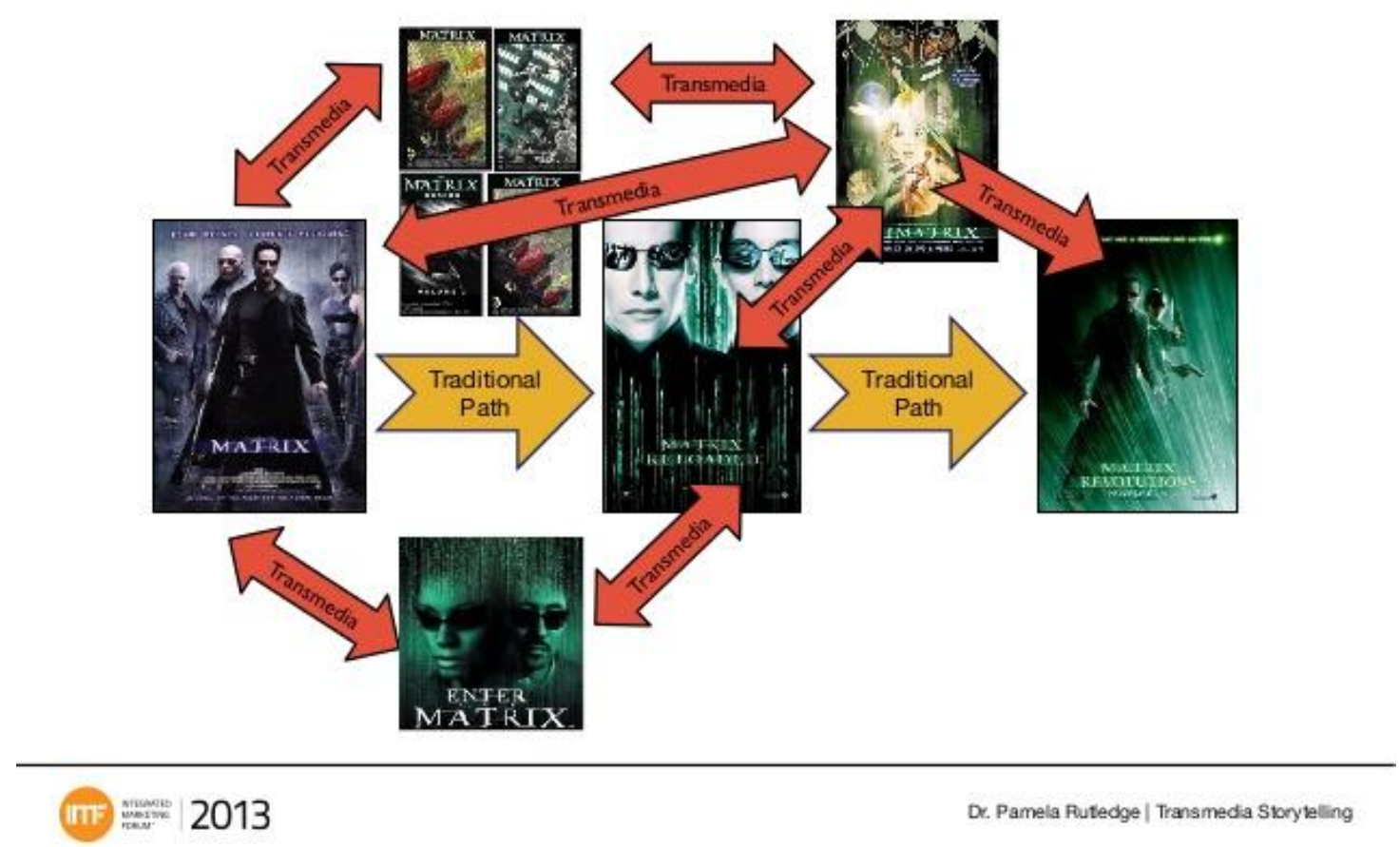

Figura 13: Exemplo de transmídia na franquia The Matrix. (RUTLEDGE, 2013, Slide 31) Fonte: https://pt.slideshare.net/pamelarutledge/transmedia-storytelling-as-a-content-marketing-strategy/27.

Quando aplicada à arte, transmídia implica a capacidade do usuário de influenciar e interagir com o objeto ou coleção, além de acessá-lo e visualizá-lo por meios distintos. (Esse assunto será desenvolvido no capítulo 3).

\subsubsection{Hipermídia}

No mesmo exemplo acima, pode-se verificar outra técnica, intimamente ligada à transmídia - a hipermídia. O locutor do programa de rádio liga o conteúdo ao aplicativo ao divulgá-lo aos ouvintes; o anúncio gráfico do telejornal que surge na telinha do celular quando se consulta o aplicativo faz a segunda associação; e,

58 JENKINS, Henry. Transmedia Storytelling 101. Março, 2007.

http://henryjenkins.org/2007/03/transmedia storytelling 101.html. Acesso em 20/11/2014. 
finalmente, as notícias na televisão terminam pela construção da narrativa de informação.

O termo original "hypermedia", inclusive, tem sua raíz na palavra "hypertext", que, na linguagem digital, são protocolos em que se acessam determinados blocos de texto que por sua vez criam uma ligação (um "link") a outro conteúdo - o que chama-se popularmente de "links", ou "hyperlinks".

O termo Hipermídia descende diretamente de Hipertexto, um protocolo de internet que referencia outros endereços e conecta-os através de hiperligações (Hyperlinks). O Hipertexto possibilita a transição de uma página à outra através do acesso, geralmente (mas não exclusivamente) com um click do mouse, no bloco de texto ou ícone que faz a referência. ${ }^{59}$

A Hipermídia, ao invés de aludir aos blocos de texto ou ícones dos Hyperlinks, corresponde às formas em que várias mídias são conectadas e como ocorre a transição de uma para outra. Diferente da Multimídia em que o caminho da informação é sequencial e linear, a Hipermídia permite acesso a várias mídias de forma concomitante; desta forma, o usuário seleciona e customiza sua experiência. Portanto, o maior diferencial da Hipermídia em relação à Multimídia é a interatividade. (GOSCIOLA, 2003).

\subsection{Cibridismo}

Já em 1964, Marshall MacLuhan afirma que da mesma forma que o homem cria a ferramenta, a ferramenta recria o homem ${ }^{60}$. Seguindo a linha de pensamento do autor, quaisquer tecnologias criadas pelo ser humano tornam-se sua extensão, um aperfeiçoamento de seu corpo e sentidos. Na época, o autor provavelmente não poderia imaginar a revolução que as tecnologias móveis trariam para o cotidiano.

\footnotetext{
${ }^{59}$ Apesar do 'Hipertexto' parecer algo exclusivamente da era digital, seu princípio já pode ser verificado nos escritos de Leonardo Da Vinci (1452-1519), que estabelecia relações entre seus textos e projetos. Entretanto, a palavra Hipertexto surge em 1963, da necessidade metodológica de se criar termos para explicar conceitos computacionais. Seu criador foi Ted Nelson (Theodor Holm Nelson 1937-), sociólogo, filósofo e um dos pioneiros da pesquisa de tecnologia da informação.

${ }^{60}$ MCLUHAN, Marshal. Os meios de comunicação como extensão do homem.
} 
Em 2014, pela primeira vez na história, o acesso à internet por dispositivos móveis ultrapassou o acesso via computador. Segundo dados divulgados pelo suplemento de Tecnologias da Informação e Comunicação (TIC) da Pesquisa Nacional por Amostra de Domicílios (PNAD) 2014, realizado em convênio com o Ministério das Comunicações - o acesso via computador foi reduzido de $88,4 \%$ para $76,6 \%$, enquanto o acesso à internet por dispositivos móveis saltou de 53,6 para $80,4 .^{61}$ Esses dados comprovam que, cada dia mais, o ser humano se tornou cíbrido.

Cíbrido, conforme a definição de Peter Anders (2001) é a combinação do universo físico e o simbólico (imagens digitais). Giselle Beiguelman (2004) afirma que cibridismo é estar entre redes, ON e OFF line ao mesmo tempo. Se nos anos 90, por exemplo, o homem era predominantemente off line, com a evolução tanto da internet quanto das tecnologias móveis, este torna-se cada dia mais conectado.

As tecnologias móveis atualmente são, portanto, uma extensão do homem ciborguizado (BEIGUELMAN, 2004) que permanece ON e OFF line, coexistindo em ambos os ambientes ao mesmo tempo, expandindo sua percepção e mantendo contato constante com diversas mentes através do globo.

Assim, comunicação, informação, compras, experiências tornaram-se cada dia mais interativas, num fluxo constante 24 horas por dia, acessíveis em uma extensão do homem cíbrido e isso faz com que o conteúdo transmidiático possa acompanhar o usuário em qualquer lugar do planeta, 24 horas por dia, envolvendo-o e incentivando sua participação.

\footnotetext{
${ }^{61} \mathrm{https}$ ://agenciadenoticias.ibge.gov.br/9564-pnad-tic-em-2014-pela-primeira-vez-celularessuperaram-microcomputadores-no-acesso-domiciliar-a-internet.html
} 


\section{Arte, Tecnologia e Comunicação}

Da mesma forma que essa complexa contemporaneidade tecnológica tange e afeta o cotidiano humano, ou permeia também o universo das artes, trazendo hibridação, experimentação e interação através de muitos meios midiáticos, que são apropriados pelos artistas, muitas vezes dentro da mesma obra.

A partir da década de 60 , concomitante ao desenvolvimento cultural e tecnológico e à banalização da mídia em massa, nasceram novas formas de arte (como performances, instalações, vídeo-arte, intermídia, etc.) que não podiam ser classificadas nos cânones tradicionais da academia (pintura, escultura, arquitetura, desenho). Nas décadas de 80 e 90, a revolução digital desestabiliza de vez as tipologias tradicionais artísticas, inserindo novas ferramentas de produção, armazenamento e circulação.

As novas ferramentas digitais também possibilitaram a divulgação do objeto artístico para um amplo espectro de observadores que estabeleceram novas formas de interação com a arte (e com a realidade, que é mediada através de um dispositivo móvel - Figura 1).

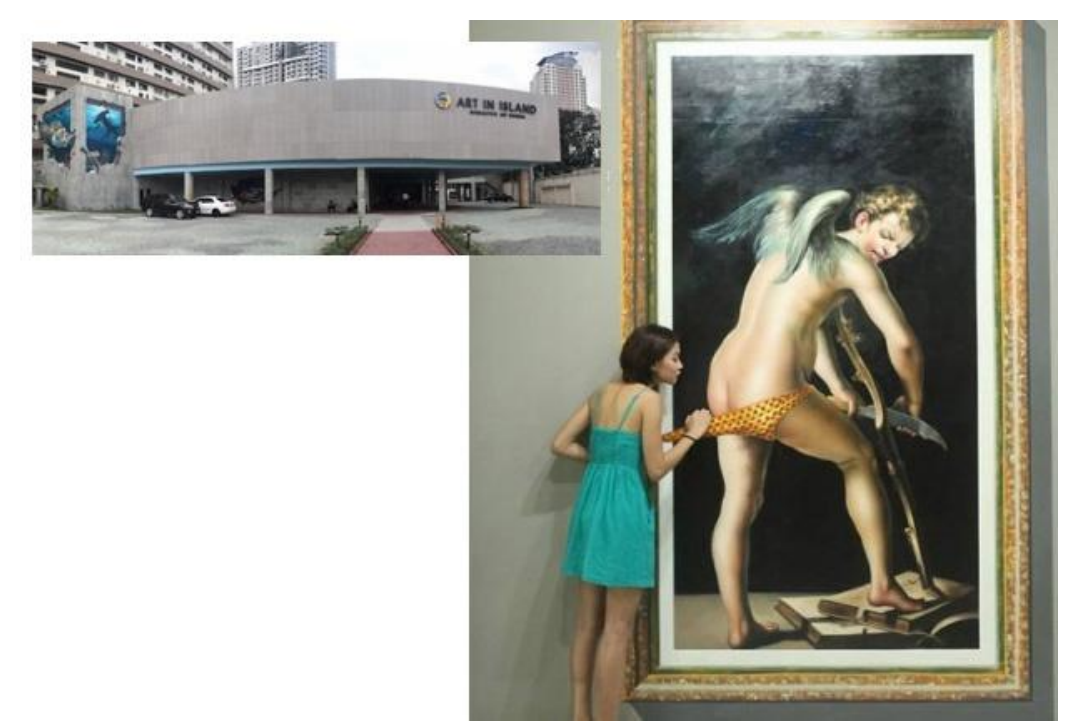

Figura 14: Museu interativo Art on Island nas Filipinas, onde o visitante tira fotografias interagindo com famosas obras de arte. Imagem disponível em: http://www.criatives.com.br/2015/03/museu-interativo-3dnas-filipinas-faz-com-que-voce-entre-dentro-das-pinturas/ Acesso 26/05/2016. 


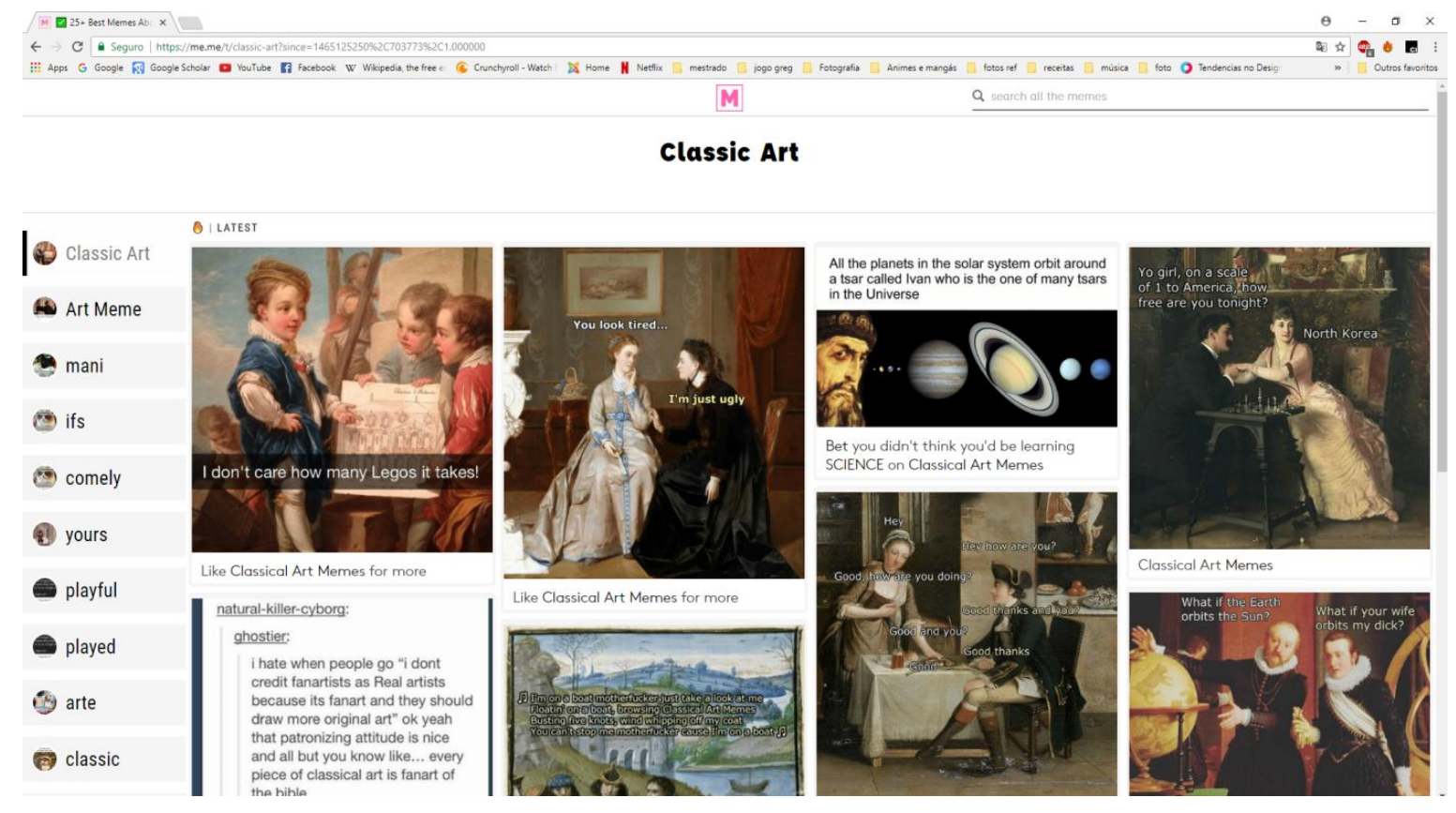

Figura 15: Site que disponibiliza Memes com obras clássicas. Disponível em: https://me.me/t/classic-art?since=1465125250\%2C703773\%2C1.000000. Acesso: 15/10/2017

A aura do objeto artístico clássico se dissolve agora entre vídeos no Youtube, em apresentações no Slideshare e em memes dentro das redes sociais (Figura 2). As obras são descritas em enciclopédias colaborativas virtuais, como a Wikipédia. Esse conjunto de informações transdisciplinares, portador de grande massa de imagens visuais, passa a ser motivo de análise. Lev Manovich cunhou o termo "Cultural Analytics", em 2007, para abranger os estudos de grandes coleções visuais a partir da internet.

O Google Art Project (projeto cultural que faz parte do Google Arts \& Culture, da corporação Alphabet) fez parcerias com museus e galerias através do globo e escolheu entidades de peso, história e prestígio, como o Museu Van Gogh em Amsterdam, o MoMA e o MET em Nova Yorque, a galeria Uffizi em Florença, e o Hermitage em São Petersburgo. Hoje o número de galerias, museus e exposições chega a quase 600, incluindo Inhotim, Instituto Moreira Salles, MAM e Pinacoteca do Estado de São Paulo, no Brasil (Figura 6). O objetivo é criar um grande banco de dados sobre arte (história, obras) utilizando o acervo das instituições parceiras, um museu de museus virtual. 
Imagens de pinturas são escaneadas com uma resolução que vai além do olho humano. O tratamento em Gigapixels foi feito na obra "The Apparition of Christ to the People" de Alexander Andreyevich Ivanov, onde pode-se observar com clareza as pessoas escondidas atrás da árvore (Figuras 3 e 4).

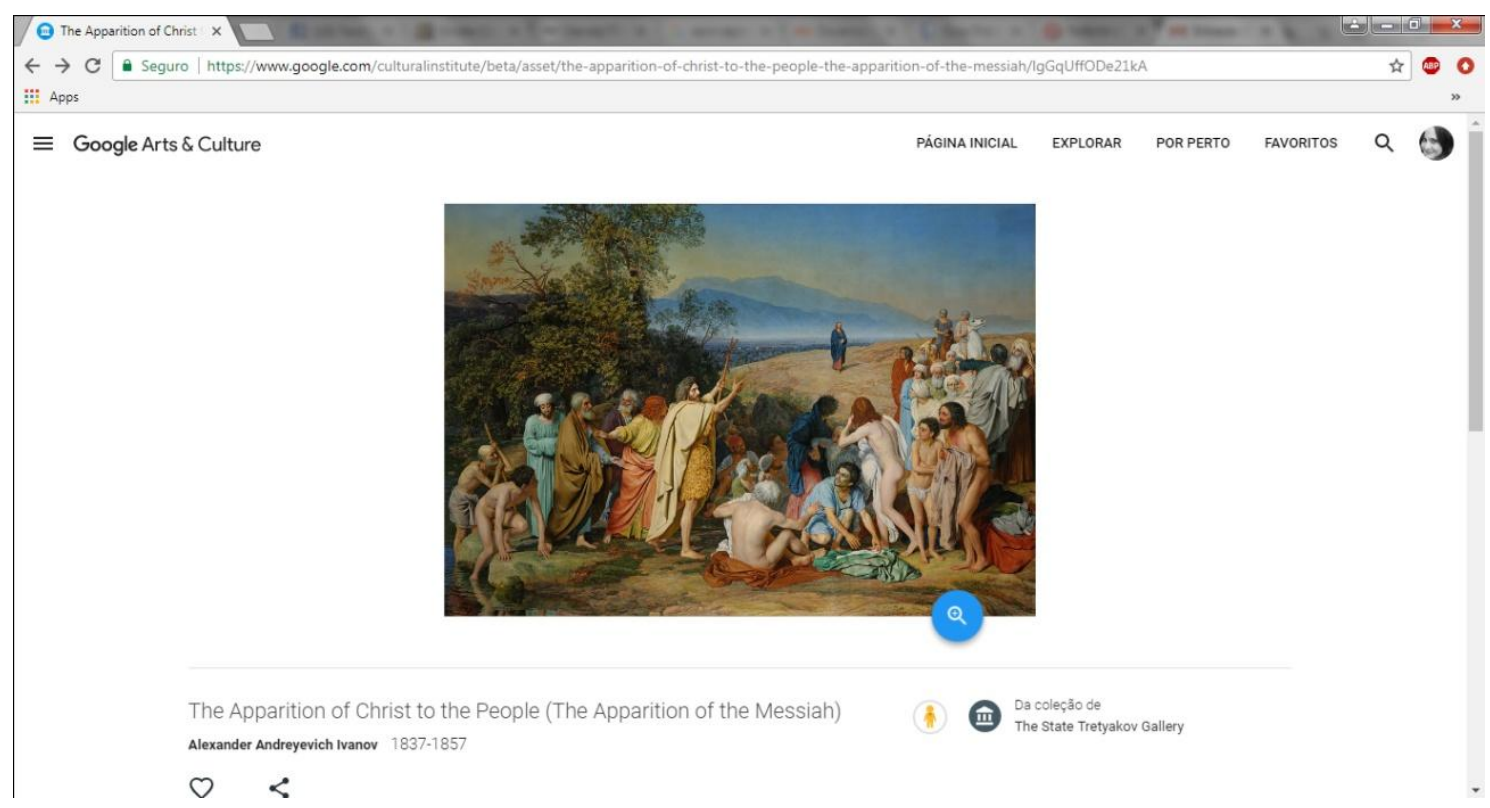

Figura 16: The Apparition of Christ to the People, de Alexander Andreyevich Ivanov. Fonte:

https://www.google.com/culturalinstitute/beta/asset/the-apparition-of-christ-to-the-people-the-apparition-of-themessiah/IgGqUffODe21kA. Acesso: 10/01/2018.

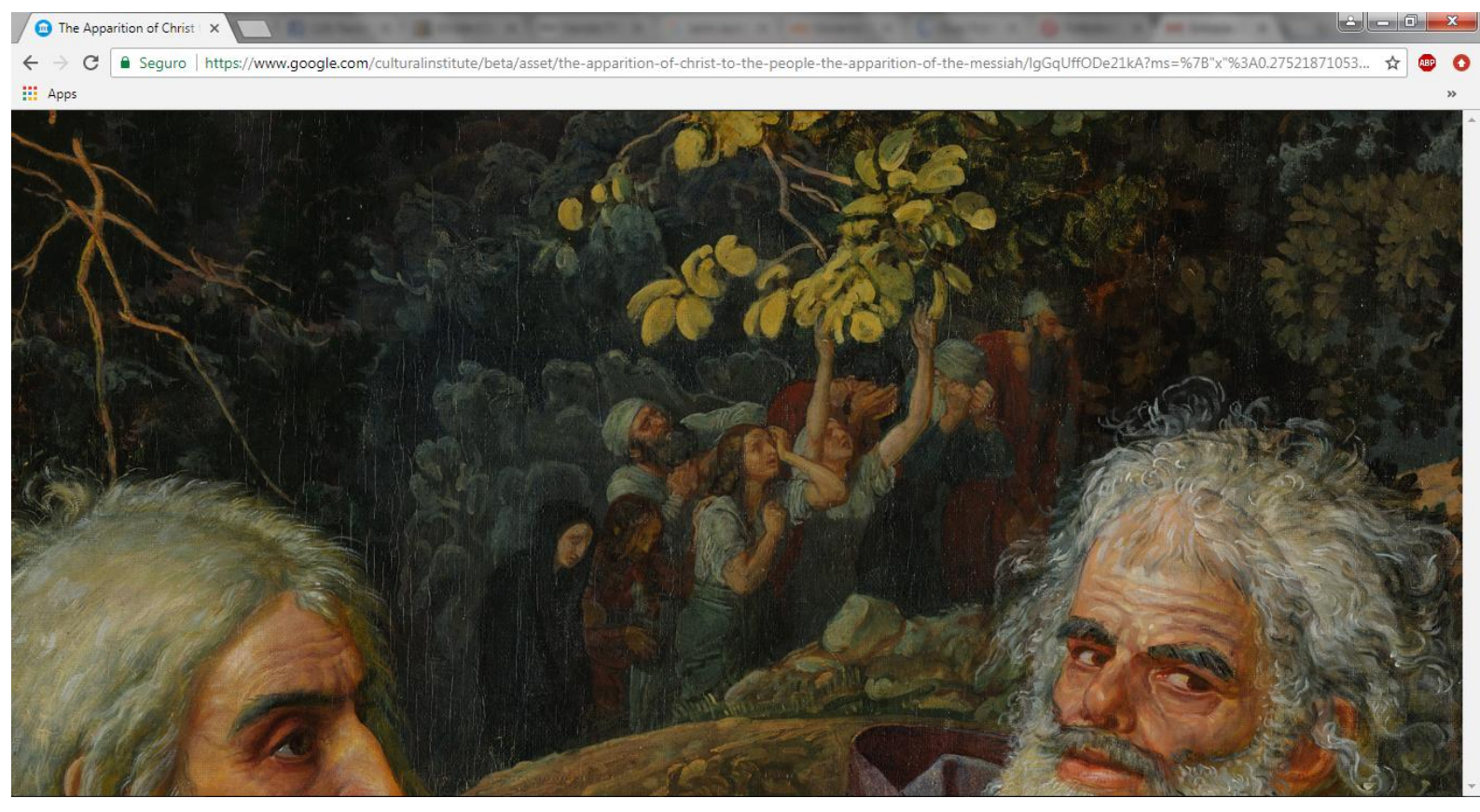

Figura 17: Detalhe aproximado com as figuras escondidas atrás da árvore. Fonte: https://www.google.com/culturalinstitute/beta/asset/the-apparition-of-christ-to-the-people-the-apparition-of-themessiah/IgGqUffODe21kA. . Acesso: 10/01/2018. 
É possível ver detalhes que normalmente passariam despercebidos e cada imagem supera a marca de sete bilhões de pixels. Para se ter uma ideia comparativa, as câmeras comerciais mais sofisticadas no momento possuem sensores de 35 Megapixels, ou trinta e cinco mil pixels.

Segundo DUBOIS (2014), dentro do universo das imagens, atualmente, "novas tecnologias" remetem a instrumentos eletrônicos, que geralmente dizem respeito à informática, e às imagens produzidas através dela. É evidente que o léxico "tecnologia" possui um significado abrangente compreendendo ciência, artes, indústria, produção, conhecimento teórico e prático ${ }^{62}$. A tecnologia, que é um conjunto do saber fazer humano, dentro das artes, pode ser apontada desde as cavernas de Pech Mele e Altamira ${ }^{63}$, passando pela pintura encáustica ${ }^{64}$ utilizada na Antiguidade, às iluminuras medievais, ao afresco que foi substituído pela tinta a óleo no Renascimento, gravuras, fotografia, cinema e finalmente o computador. "Todas essas 'máquinas de imagens' pressupõe (ao menos) um dispositivo que institui uma esfera 'tecnológica' necessária à constituição da imagem [....]." (DUBOIS, posição 348 e 349,2014$)$.

As discussões sobre as relações entre arte e tecnologia e seus efeitos sobre o pensamento, no processo e realização artísticos, são objeto de estudo intelectual constante. Dentro da fotografia (desenvolvida no século XIX por Niépce, Daguerre e Talbot $)^{65}$, o norte-americano Alfred Stieglitz ${ }^{66}(1864$ - 1946) tornou-se figura central da valorização da imagem feita pela câmera fotográfica como obra de arte. Ele acreditava que a fotografia devia ser encarada como uma entidade autônoma, capaz de tornar-se a forma principal de arte do século $X X{ }^{67}$

\footnotetext{
${ }^{62}$ Segundo dicionário Michaelis.

${ }^{63}$ Pech Mele (França) e Altamira (Espanha) são cavernas com pinturas rupestres do período Paleolítico Superior.

${ }^{64}$ Encáustica é uma técnica de pintura com base em cera como aglutinante de pigmentos.

${ }^{65}$ Joseph Nicéphore Niépce $(1765$ - 1833) fez a primeira imagem técnica fixada com betume da judéia em 1826, Louis-Jacques-Mandé Daguerre (1787 - 1851) em sociedade com Nièpce continuou a pesquisa, mesmo depois da morte do mesmo em 1833 desenvolvendo assim o Daguerreótipo. William Henry Fox Talbot $(1800$-1877) desenvolveu contemporaneamente a ambos sua própria pesquisa em busca da fotografia, sendo o primeiro a conseguir uma imagem reprodutível a partir de um negativo (Calótipo).

${ }^{66}$ Criou a Fotossecessão em 1902. Para fornecer espaço de exposição para o grupo, ele fundou a primeira de suas três galerias de Nova lorque, que foi conhecida como Galeria 291, fechada em 1917. Foi vice-presidente do Camera Club de Nova York e tornou-se também editor da revista Camera Work, transformando-a, de um periódico institucional em produção moderna e premiada. ${ }^{67}$ HACKING, Juliet (org). Tudo sobre fotografia. Rio de Janeiro: Sextante, 2012.
} 
O pensamento de Stieglitz elucida um dos encontros e embates entre arte e tecnologia na história da arte. De um lado alguns críticos consideravam a fotografia como uma curiosa engenhoca, excelente para a criação de retratos, sem reconhecer seu caráter estético. Um exemplo conhecido é a relação ambígua de Charles Baudelaire $^{68}$ (1821-1867) com a fotografia. Ele a criticava duramente, por crer que, eventualmente, a fotografia substituiria a pintura. No entanto, era amigo de fotógrafos e menciona em suas cartas para a mãe, a vontade de ter uma fotografia da mesma: "um retrato exato, mas tendo o flou de um desenho" 69 .

A hibridação entre tecnologia e arte trouxe uma série de questionamentos tanto no sistema da arte (museus, curadores, críticos), que tinha dificuldade em assimilar obras que desafiavam o status quo da arte (como grandes instalações e obras digitais) como na perda da "aura" da obra partir de sua reprodutibilidade técnica, como Walter Benjamim já apontava em 1936 em seu texto "A obra de arte na época da reprodutibilidade técnica":

[...] o que desaparece na época da reprodutibilidade técnica da obra de arte é a aura. Esse processo é sintomático; seu significado vai muito além da esfera da arte. A técnica de reprodução, assim se pode formular de modo geral, destaca o reproduzido da esfera da tradição. Na medida que multiplica a reprodução, coloca no lugar de sua ocorrência única sua ocorrência em massa. $E$, na medida em que permite à reprodução ir ao encontro daquele que a recebe em sua respectiva situação, atualiza o que é reproduzido. (BENJAMIM, 2012)

Por outro lado, o Pictorialismo (séc. XIX) e a Fotossecessão (séc XX) são dois exemplos do esforço de fotógrafos em estabelecer a fotografia no cenário artístico. No Pictorialismo, Oscar Gustave Rejlander (1813-1875), Henry Peach Robinson $(1830-1901)^{70}$, entre outros fotógrafos, através do uso de alegorias, composições que lembrassem os temas pictóricos, montagens retoques, granulações, tentavam aproximar a fotografia da pintura. Já a Fotossecessão, fundada por Sieglitz, junto com os fotógrafos Edward Steichen (1879 - 1973), John G. Bullock (1854 - 1939),

\footnotetext{
${ }^{68}$ Poeta francês que também atuou com crítico de arte.

${ }^{69}$ RAMOS, Matheus Manzini. Fotografia e arte: demarcando fronteiras. Revista Contemporânea, Rio de Janeiro, no 12 p.129-142, 2009.

${ }^{70}$ Ambos ex-pintores que tornaram-se fotógrafos.
} 
Frank Eugene (1865 - 1936), Gertrude Käsebier (1852 - 1934), Dallet Fuguet (1868 1933), Joseph Keiley (1869 - 1914) e Clarence White (1871 - 1925), ofereceu um novo rumo para a fotografia, sem tentar imitar a arte do passado ${ }^{71}$.

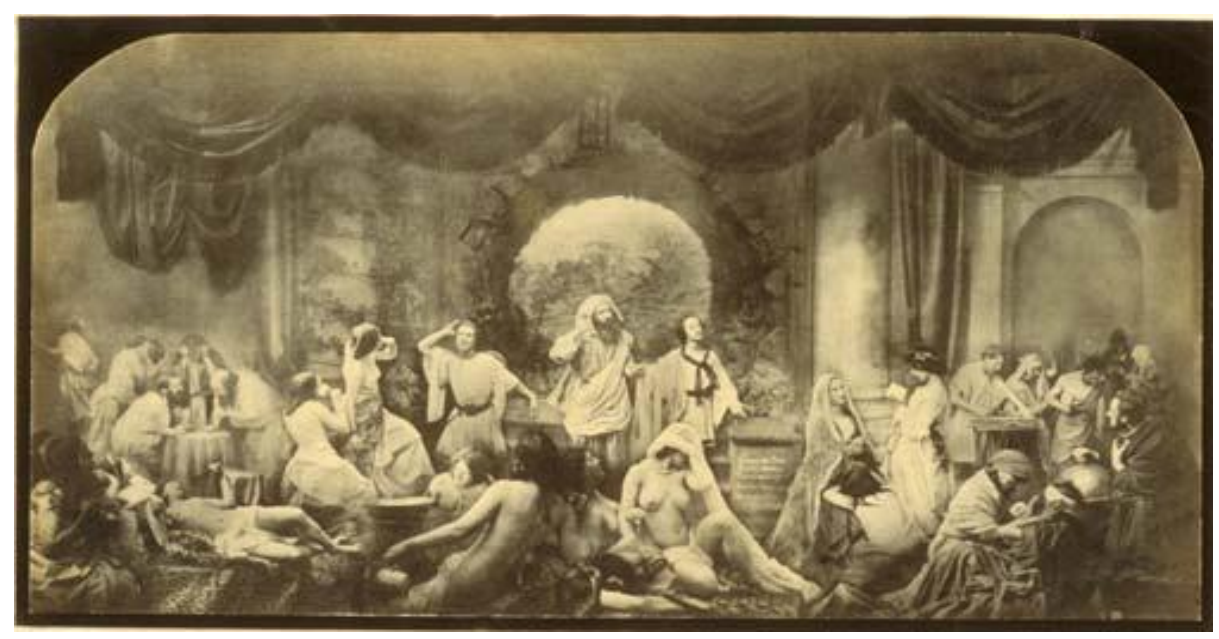

Figura 18: Oscar Gustave Rejlander, Os dois caminhos da vida (1875) é a sua obra mais conhecida e possivelmente uma das mais paradigmáticas feitas através da técnica da fotomontagem. Para a sua realização foram utilizados mais de trinta negativos diferentes. Fonte: https://commons.wikimedia.org/wiki/File:Oscar-gustaverejlander_two ways_of life_(HR,_sepia).jpg. Acesso: 01/01/2017.

A pesquisa de Muybridge ${ }^{72}$ (1830-1904), de 1878, que fez uso de múltiplas câmaras para captar o movimento, e a de Etienne-Jules Marey ${ }^{73}$ (1830-1904), com a "cronofotografia", não apenas influenciaram artistas plásticos, mas tiveram efeito profundo no Futurismo [que pode ser notado nas obras de Giacomo Balla (18711958), Marcel Duchamp (1887-1968), Kurt Schwitters (1887-1948)]: tais pesquisas também evoluíram para o cinema, a partir do estudo de movimento utilizando múltiplas fotografias.

O cinema, desenvolvido no século XIX por Thomas Edison (1847-1931) nos EUA e pelos Irmãos Lumière, na França ${ }^{74}$, trouxe uma série de contribuições para 0

\footnotetext{
${ }^{71}$ HACKING, Juliet (org). Tudo sobre fotografia. Rio de Janeiro: Sextante, 2012.

${ }^{72}$ Fotógrafo inglês conhecido por seus experimentos com o uso de múltiplas câmaras para captar o movimento, além de inventor do zoopraxiscópio - dispositivo para projetar os retratos de movimento que seria o precursor da película de celuloide que é usada ainda hoje.

${ }^{73}$ Cientista e médico Francês que também fez pesquisas fotográficas. Em 1882 criou sua espingarda fotográfica que tirava 12 imagens por segundo.

${ }^{74} \mathrm{Em} 1891$, Thomas Edison inventou o cinetógrafo e posteriormente o cinetoscópio. Auguste (18621954) e Louis Lumière (1864 - 1948) inventaram o cinematógrafo, e foram considerados pais do cinema ao organizar uma exibição pública paga de filmes no dia 28 de dezembro no Salão do Grand Café de Paris. Porém, as histórias americanas atribuem um maior peso a Thomas Edison pela invenção do cinema; entretanto o que ele fez foi reunir pequenos vídeos e exibi-los em máquinas
} 
meio artístico. A partir desse momento, a fotografia não é mais estática, mas sim uma projeção de uma sequência de fotografias, que proporcionam a ilusão de movimento contínuo, apresentando uma imagem que se aproveita de um pequeno defeito do olho humano, conhecido como "persistência retiniana"75 para criar um movimento fluido, que imita a realidade. Considerado o "primeiro artista da tela", George Meliès (1861-1938) foi pioneiro em filmes que fundiam fotografia, exposições múltiplas e cor pintada à mão. Entre seus filmes, um dos mais populares é " $A$ trip on the moon", de 1902, onde um foguete pousa no olho do "homem da Lua".
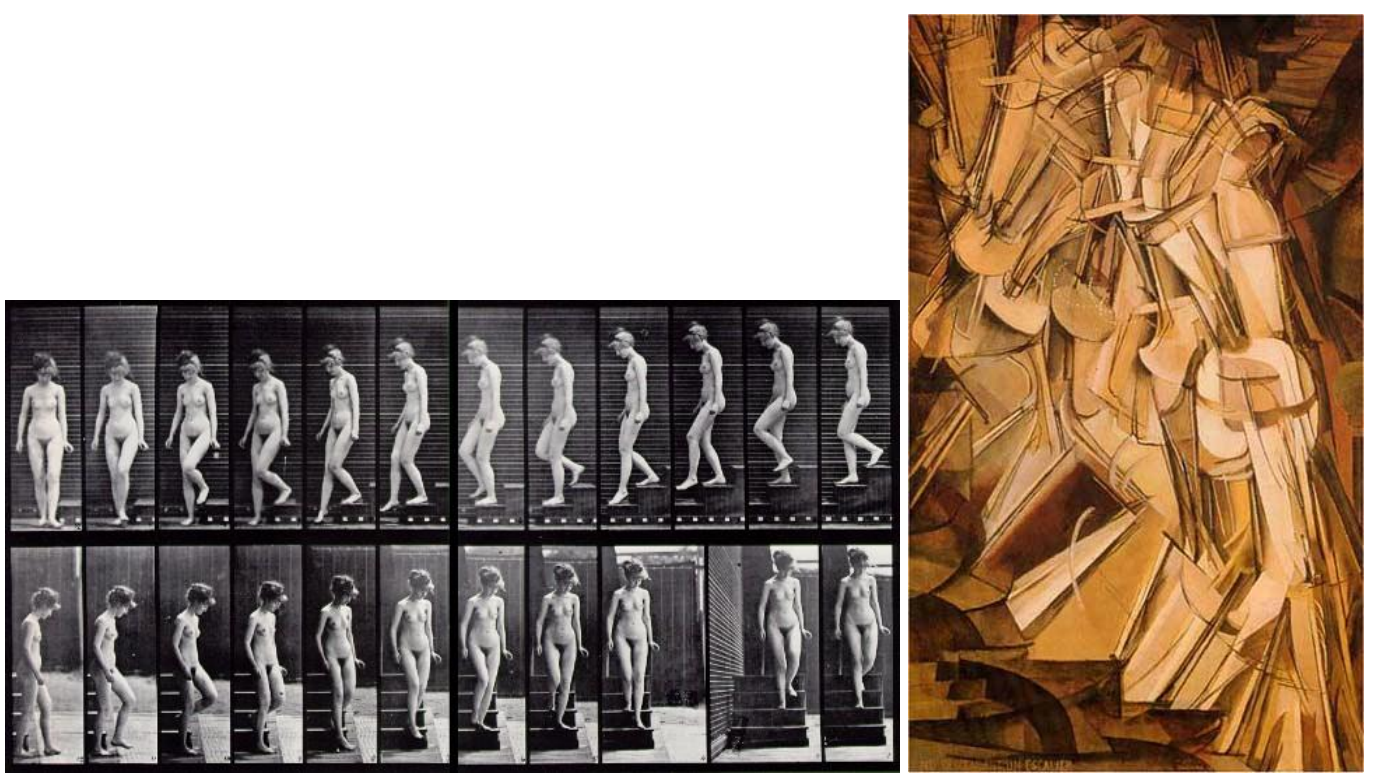

Figura 19: Muybridge à esquerda, $\mathrm{Nu}$ descendo escada, fotografia, 1887. Fonte: https://www.researchgate.net/publication/37986855 Understanding Human Motion A Historic Review. Acesso:

21/09/2017. À direita, Marcel Duchamp, Nu descendo uma escada no 2, óleo sobre tela, 1912. Fonte: https://en.wikipedia.org/wiki/Nude Descending a Staircase, No. 2. Acesso: 21/09/2017.

caça-níquel, e para não perder tal fonte lucrativa, sempre foi contra a exibição dos filmes em grandes salas.

${ }^{75}$ Continuidade da percepção registrada pela retina depois de cessar o estímulo que a provocou. $\mathrm{O}$ fato da retina conservar, num instante, a percepção de uma imagem enquanto registra a que apresenta a seguinte, permite, no caso de fotogramas sucessivos, que o movimento se perceba com continuidade. 


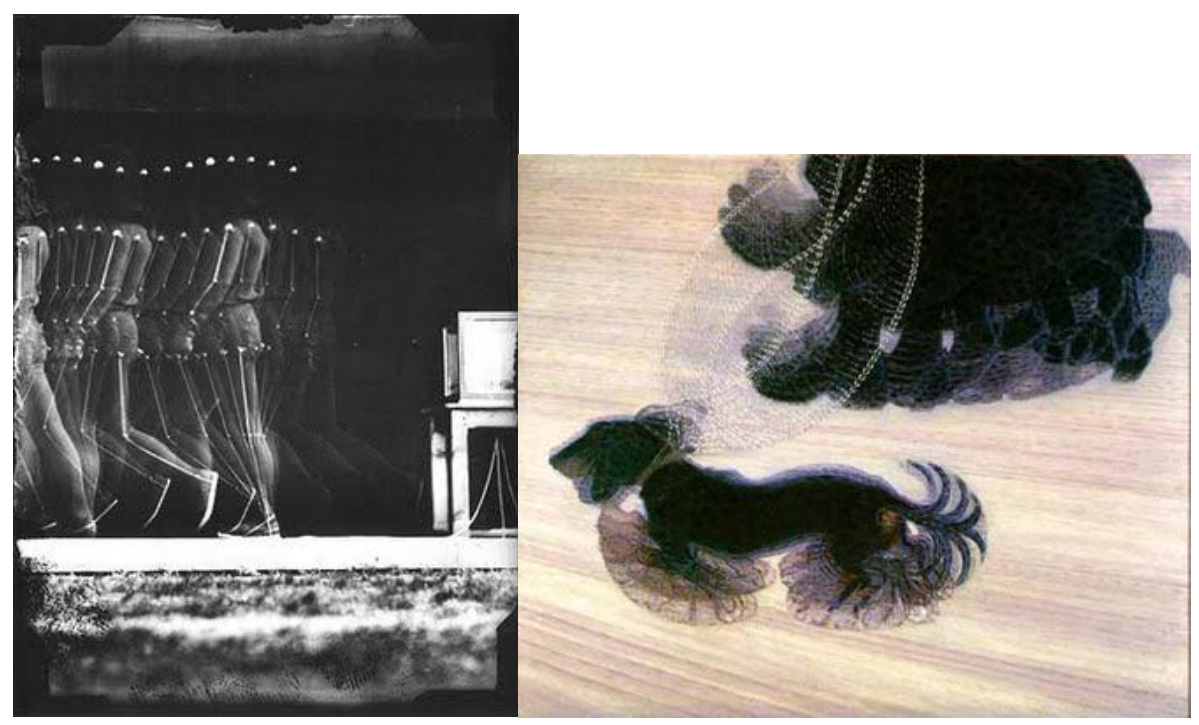

Figura 20: ̀̀ esquerda, Etienne-Jules Marey, Homme qui marche, fotografia, 1883. Fonte: https://fr.wikipedia.org/wiki/\%C3\%89tienne-Jules Marey\#/media/File:Marey-

Man walking, 1890\%E2\%80\%9391.jpg. Acesso: 21/09/2017.

A direita Giacomo Balla, Dynamism of a dog on a Leash, oleo sobre tela, 1912. Fonte: https://en.wikipedia.org/wiki/Dynamism_of_a_Dog_on_a_Leash Acesso: 21/09/2017.

Apesar de o cinema ter evoluído para grandes produções hollywoodianas, sua importância dentro da arte pode ser exemplificada nos "Fluxfilms", quarenta filmes de curta metragem criados por diversos artistas associados ao grupo Fluxus. Esses filmes fogem da tipologia tradicional do cinema, por exemplo, no filme "Anemic Cinema" - filme experimental criado por Marcel Duchamp (no estúdio de Man Ray) -, a trama é caracterizada pela ausência de personagens e de narrativa convencional. Da mesma forma, o filme surrealista "O cão Andaluz", feito pela parceria entre o diretor Luis Buñuel (1900-1983) e o artista Salvador Dalí (1904-1989), tem uma cronologia desarticulada, explorando os absurdos do sonho e do inconsciente.

Essas máquinas tecnológicas assimiladas ao universo artístico, segundo DUBOIS (2014) são "intermediários que vêm se inserir entre o homem e o mundo no sistema de construção simbólica que é o princípio mesmo da representação". A fotografia coloca em cheque a interpretação do sujeito sobre a realidade. No século XIX, daguerreótipos eram considerados tão realistas que eram chamados de espelhos do real ${ }^{76}$. Entretanto uma fotografia pode ser manipulada através de luz, cortes, retoques, mesmo ainda na época dos daguerreótipos em que alguns apresentam inserção de cor no rosto, para dar um aspecto mais "vivo" à imagem.

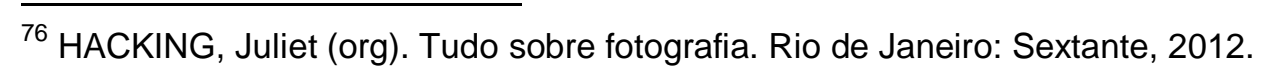


A fotografia gera uma imagem concreta, um objeto manuseável. No cinema, em outra etapa técnica, para se observar a imagem, é necessário um mediador tecnológico, como no cinematógrafo. Além disso, um novo conhecimento com relação à percepção teve de ser desenvolvido.

Sua força (do cinema) reside não apenas na dimensão tecnológica, mas primeiro e, sobretudo na simbólica: o cinema é tanto uma maquinação (uma máquina de pensamento) quanto uma maquinaria, tanto uma experiência psíquica quanto um fenômeno físico perceptivo. Sua maquinaria não é só produtora de imagens como também geradora de afetos, e dotada de um fantástico poder sobre o imaginário dos espectadores. (DUBOIS, posição 491,2014 )

Nas artes plásticas, o século XX é caracterizado pela "natureza experimental" das obras. Não apenas a pintura e a escultura obtêm espaço. Os artistas questionaram a arte em si, incorporando objetos cotidianos em suas obras, meios de comunicação em massa, novas tecnologias (como arte digital ou realidade aumentada), vídeo, performances, computação, realidade virtual e uma série de formas de interação entre o receptor (ou observador) e o trabalho. A arte ficou conectada com o "pessoal" tanto do artista quanto do receptor, que passa a ser parte, muitas vezes, do próprio objeto artístico. ${ }^{77}$ Esse elo entre autor e observador, e a incorporação de diversos objetos e tecnologias à arte, que já podem ser observados nesse momento, serão fundamentais na construção do pensamento transmidiático.

Marcel Duchamp ${ }^{78}$ (1887 - 1968), entre outros, acreditava nessa nova visão da arte em que o artista estaria bem no meio da obra e o observador passaria a orbitar e a interagir com a mesma. Segundo Michael Rush, o artista obtém liberdade ao se expressar através de qualquer meio que ache pertinente ao seu conceito. "Este conceito pode se relacionar à história da arte, à política, ou à política do eu" 79 .

A progressão da dialética entre dois lados, estética e tecnologia, influencia na própria invenção de novos dispositivos técnicos, geradores de ambientes onde ambos possam se encontrar. Com o advento da televisão e posteriormente do vídeo, uma nova relação com a imagem e a linguagem toca os quatro cantos do planeta. A

\footnotetext{
${ }_{77}^{77}$ USH, Michael. Novas mídias na arte contemporânea. Martins Fontes, São Paulo, 2006.

${ }^{78}$ Marcel Duchamp é um artista francês, naturalizado americano que desafiou a própria noção de arte com suas obras ready-mades.

${ }^{79}$ RUSH, Michael. Novas mídias na arte contemporânea. Martins Fontes, São Paulo, 2006.
} 
televisão é "capaz de registrar, transmitir e reproduzir simultânea e quase instantaneamente uma imagem em movimento" (COUCHOT in PARENTE, 1993 p.37). Transmissão de conteúdo atinge qualquer lugar em que haja um receptor.

A TV, diferente do cinema, decompõe uma imagem móvel em uma câmera eletrônica, por meio de pontos e finas linhas paralelas que compõem a imagem em uma espécie de mosaico luminoso, apresentando um espectro imenso de cores a partir da síntese aditiva, a partir das cores-luz RGB (Red, Green e Blue). Essa imagem, segundo COUCHOT (in PARENTE,1993, p.38), tem relação direta com o real, já que seu enquadramento e perspectiva ainda fazem parte da mesma matriz representativa herdada da pintura, transferida para a fotografia e continuada pelo cinema.

A partir desse momento, o receptor não se desloca para uma sala escura e isolada onde fica absorto no universo audiovisual. Com a televisão, distância e multiplicação se tornam regra do novo ver, em que o espectador anônimo passa a ser um número, ou índice de audiência dentro da comunicação em massa.

Nos anos 60, a videoarte nasce em um mundo cada vez mais dominado pela comunicação em massa. Uma ideia fundamental para a primeira geração de videoartistas, segundo Cristine Hill ${ }^{80}$, é que "para haver uma relação crítica com a sociedade televisual, era preciso primeiramente participar de forma televisual".

De acordo com RUSH (2006, p. 80,81), a arte através do vídeo, ao contrário dos comerciais exibidos pela televisão e pelo cinema, está na intenção do artista. Temas frequentes eram tempo e memória enquanto a espontaneidade e a instabilidade do vídeo eram pontos cruciais. Desta forma, a vídeoarte questiona e critica não só os estereótipos que são trabalhados nos veículos de imagem em massa, mas também o consumidor passivo da TV e do cinema.

De fato, a crítica aos sistemas de comunicação televisiva, a denúncia dos mecanismos ideológicos que sustentam a televisão e a reconsideração do papel passivo do telespectador forneceram a temática central para os primeiros artistas da televisão e do vídeo. (MATUCK, 2009, p. 149).

${ }^{80}$ Curadora do Museu de Arte Moderna de São Francisco, in RUSH, Michael. Novas mídias na arte contemporânea. 
Em 1965, no Cafe au Go Go, concretiza-se a primeira apresentação de videoarte (nos EUA), quando o artista coreano do grupo Fluxus, Nam June Paik (1932-2006), após comprar uma câmera Portapak da Sony, filmou do interior de um táxi, a comitiva do Papa passeando pela Quinta Avenida. A questão da intenção é colocada nesse vídeo de Paik que, ao contrário de uma reportagem jornalística, era um vídeo tosco, não comercial, uma extensão de sua obra artística e uma expressão pessoal do evento. "Os artistas e os produtores independentes buscavam estabelecer uma linguagem própria, [...] oposta à da televisão, e se propunham a formar um novo tipo de espectador" (MATUCK, 2009).

O artista alemão Wolf Vostel (1932-1998) se apropria da TV como "escultura artística do século XX" na obra TV De-coll/ages (1958), quando coloca seis telas de TV em uma caixa de madeira atrás de uma tela branca. Tanto Vostel, quanto Paik, ao recontextualizar o aparelho de TV, inauguram uma nova forma de ver e proporcionam uma nova convergência dentro da arte tecnológica.

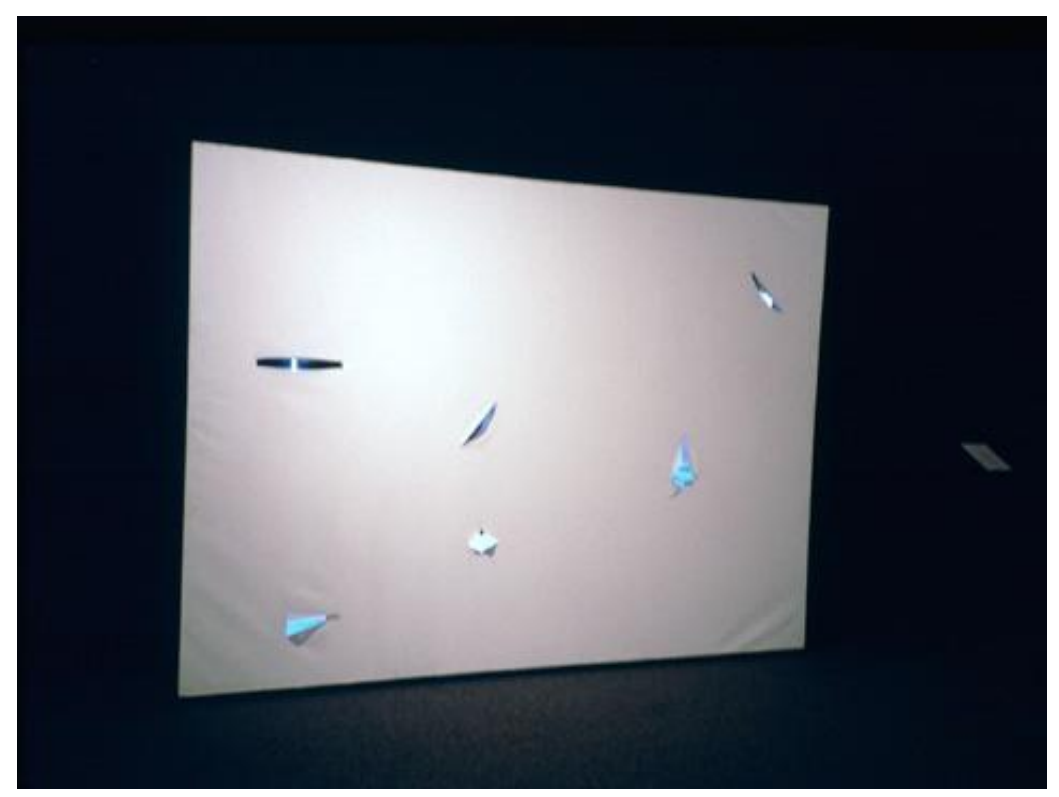

Figura 21: TV De-coll/ages, Wolf Vostel, 1958. Fonte: http://www.medienkunstnetz.de/works/tv-decowage/images/2/. Acesso 05/08/2017.

Depois das novas técnicas de criação, projeção e transmissão de imagens, surge outra tecnologia de grande impacto no universo artístico: o computador.

Trata-se da imagem informática, também chamada de imagem de síntese, infografia, imagem digital, virtual, etc. A maquinaria que aqui se 
introduz é extrema. Ela vem não apenas se acrescentar às outras (como era o caso das máquinas de captação, inscrição, visualização e transmissão), como também, por assim dizer, voltar ao ponto de partida e refazer, desde a origem, o circuito da representação. De fato, com a imagem informática, pode-se dizer que é o próprio "Real" (o referente originário) que se torna maquínico, pois é gerado por computador. (DUBOIS, posição 519-520, 2014)

Nesse momento, iniciam-se as convergências das mídias para o computador; a arte passa da produção através de máquinas ópticas para máquinas de processamentos numéricos resultantes da colaboração ente artistas, cientistas, programadores, técnicos e o computador. No meio fluido e mutável do computador, um mundo interativo se desenrola e posteriormente adicionará a participação do observador. A obra de arte não é mais apenas um objeto concreto como uma pintura em tela ou uma escultura; a imagem digital é em si uma obra de arte imaterial.

A partir do início da computação, o governo americano apoiou intensas investigações experimentais em tecnologia computadorizada, algumas envolvendo música e arte com a intenção de explorar os limites dessas máquinas computacionais e sua inteligência artificial. Desde 1963, quando A. Michael Noll (1939-) desenvolveu suas imagens geométricas abstratas em programas rudimentares, até os dias de hoje, a arte digital se desenvolveu e se reinventou diversas vezes.

Cada vez mais atuantes e imprescindíveis em ilimitados aspectos da sociedade moderna, os computadores digitais logo foram assimilados e pesquisados com uso próprio pelo pensamento da arte. As máquinas "cerebrais" tornaram-se instrumento de novas formas de inventividade e também passaram a influir nas formas de arte em vigor ${ }^{81}$.

Esse novo meio pode abranger, tecnologicamente, todas as áreas da arte contemporânea (filmes, texto, música vídeo, etc.). Dois exemplos do início dessa tecnologia no universo da arte é Poem Field (1964), de Stan Vanderbeek (19271984), em que imagens abstratas geradas por computador compõem um filme, e

\footnotetext{
${ }^{81}$ Zanini, Walter. A arte de comunicação telemática: a interatividade no ciberespaço. ARS (São Paulo) vol.1 no.1 São Paulo, 2003.
} 
Catalog (1961), um curta metragem constituído por imagens abstratas geradas por antigos computadores militares, de John Whitney (1917-1995).
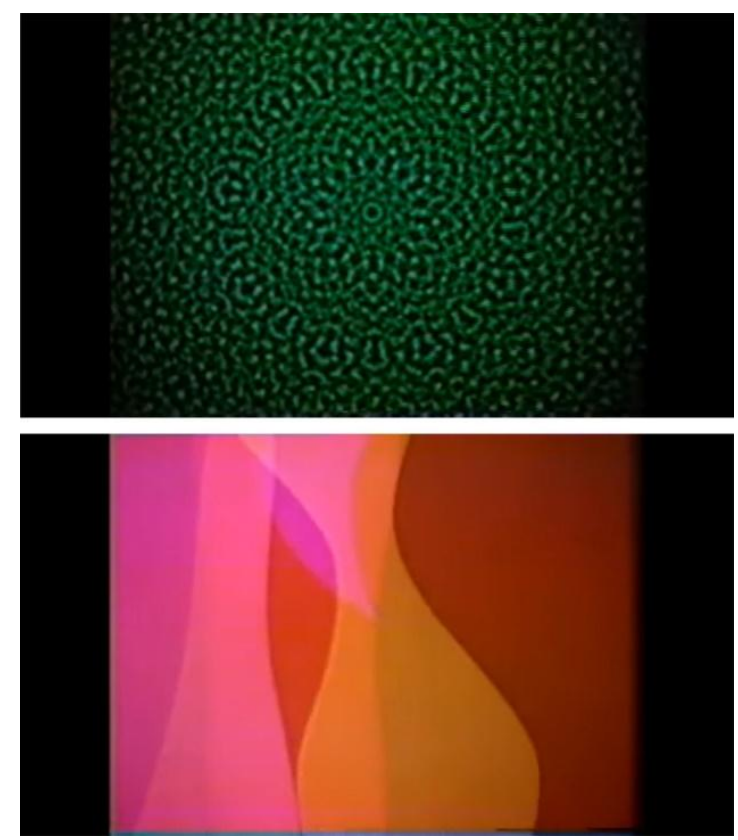

Figura 22: Imagens extraídas de Catalog (1961), John Whitney. Fonte: https://www.youtube.com/watch?v=TbV7loKp69s. Acesso: 05/08/2017.

Entretanto, a arte digital sofreu resistência tanto da crítica quanto do público. Da mesma forma que a fotografia sofreu preconceito, havia resistência com relação à ideia de uma obra reprodutível, longe dos cânones tradicionais e imateriais. $\mathrm{O}$ mercado artístico também permaneceu fechado a essa manifestação artística. Esse quadro começa a se reverter a partir dos anos 90, com o advento da internet. $A$ possibilidade da troca de dados através do globo foi apropriada pelos artistas, que passaram a elaborar obras interativas e inovadoras, que não necessitavam de uma galeria ou museu para serem expostas. (LIESER, 2009)

\section{1 Imersão e realidade virtual}

A imersão e a realidade virtual são ferramentas comumente utilizadas contemporaneamente para compor uma obra transmidiática. Atualmente, a palavra imersão é constantemente utilizada para significar a relação do público com as mídias. Cada vez mais a publicidade, o cinema, o jornalismo e a arte se utilizam 
desse recurso para despertar o envolvimento emocional do espectador, estimular a atenção para o objeto em questão e dirigi-lo para a mensagem a ser transmitida. Esse recurso, longe de ser uma exclusividade de tecnologias digitais, já está presente no universo artístico desde a Roma antiga, quando os pintores criavam painéis para afetar a percepção das pessoas tendo por objetivo ampliar o espaço de um cômodo através da ilusão da perspectiva.

Dentro da história da arte, exemplos podem ser encontrados também no Renascimento (como a Sala da Perspectiva, Villa Farnesina, Roma) ou no Barroco com panoramas nos tetos de igrejas (movimento Sacri Monti). No século XVIII, o pintor irlandês Robert Barker (1739-1806) cunhou o termo panorama (do grego pan - tudo e horama - vista) para explicar suas criações pictóricas.

$\mathrm{Na}$ perspectiva tecnológica atual, essas técnicas rudimentares podem não parecer suficientes; entretanto, em sua época, impressionavam o observador. Para ilustrar essa percepção do público, GRAU (2007, p. 120) cita o jornal alemão Neue Preussiche Zeitung, que publica em 1883 um relato sobre o panorama A Batalha de Sedan $^{82}$ :

O visitante é capturado de imediato; tomado de todo pela surpresa, instintivamente se detém. O medo de ser pisado pelos cascos dos cavalos o impele a recuar. Poeira e fumaça em redemoinhos parecem tomar o ar. Trombetas ressoam e tambores ribombam. Em um massacre esmagador, a cavalaria ataca. Quantos cavalos! São os franceses! Esta é a primeira impressão

Para apreciar essa obra, era necessário percorrer uma passagem escura que terminava em uma plataforma onde o público ficava cercado de imagens iluminadas que entorpeciam sua percepção e criavam uma sensação ilusória de estar dentro da pintura.

Esses espaços expandidos se desenvolveram paralelamente à tecnologia: a fotografia estereoscópica ${ }^{83}$, o estereóptico ${ }^{84}$, o cineorama ${ }^{85}$ entre outras máquinas

\footnotetext{
82 De Anton Von Werner, pintado por E. Bracht e treze outros pintores.

83 Inventada por Charles Wheatstone em 1938 - combina duas imagens, que, observadas através de um par de óculos, trazem a ilusão de profundidade.

84 Um aparelho que utilizava dezesseis projetores de slide para projetar imagens em uma tela circular.

85 Mídia híbrida em que dez filmes eram projetados simultaneamente para criar uma imagem 360 graus.
} 
projetadas para criar a imersão, evoluíram na era digital para a realidade virtual ${ }^{86}$, termo paradoxal já que descreve um espaço ilusório e imaterial.

Essa imaterialidade é somada à ideia de imersão a partir dos anos 1990: a realidade virtual e a realidade aumentada também passam a ser instrumentos de poética artística. Pode-se usar como exemplo de imersão e interatividade as CAVEs (Cave Automatic Virtual Environment), ambientes em que se projetam gráficos 3D nas paredes ou usam-se capacetes de múltiplas projeções (GRAU, 2007).

No século XXI, a arte permeada pela tecnologia traz novos métodos para a imersão em uma obra através de máquinas conectadas, ubíquas no cotidiano. Um exemplo são os óculos de VR (realidade virtual) que podem ser acoplados à telefones celulares que possuam um APP (aplicativo para celular) específico para a função. Imagens 3D podem ser observadas através do dispositivo, que se tornou um aparato moderno das antigas fotografias estereoscópicas.
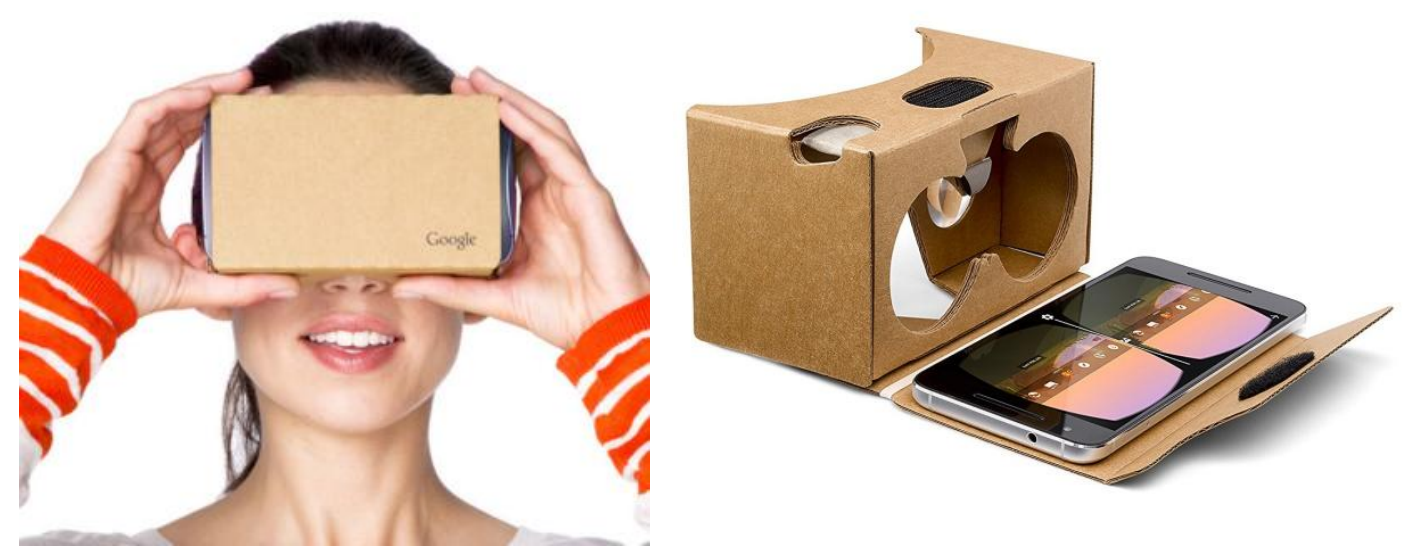

Figura 23: Óculos de VR (realidade virtual) de papelão da marca Google. Eles podem ser acoplados a telefones celulares Fonte: https://www.amazon.com/Google-87002822-01-OfficialCardboard/dp/B01L92Z8D6. Acesso: 10/12/2017.

Outro exemplo interessante desse novo tipo de imersão é o Tilt Brush, um App que permite que o desenho seja feito no ar, e o artista pode andar em meio a sua obra. Parece um tanto complexo de entender, afinal, como desenhar no ar? Através de um kit de realidade virtual, usando óculos e controladores, o usuário entra em um ambiente escuro onde pode desenhar "no ar" e andar 360 graus em volta de sua criação.

\footnotetext{
${ }^{86}$ Termo cunhado em 1989 por Jaron Lanier.
} 


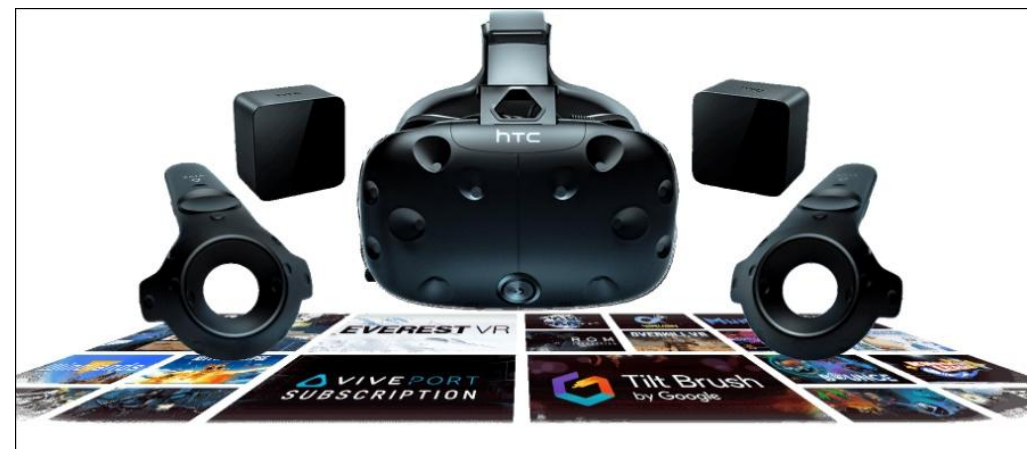

Figura 24: Kit de realidade virtual da marca HTC Vive. Fonte: https://www.vive.com/us/product/vivevirtual-reality-system/. Acesso: 10/12/2017.

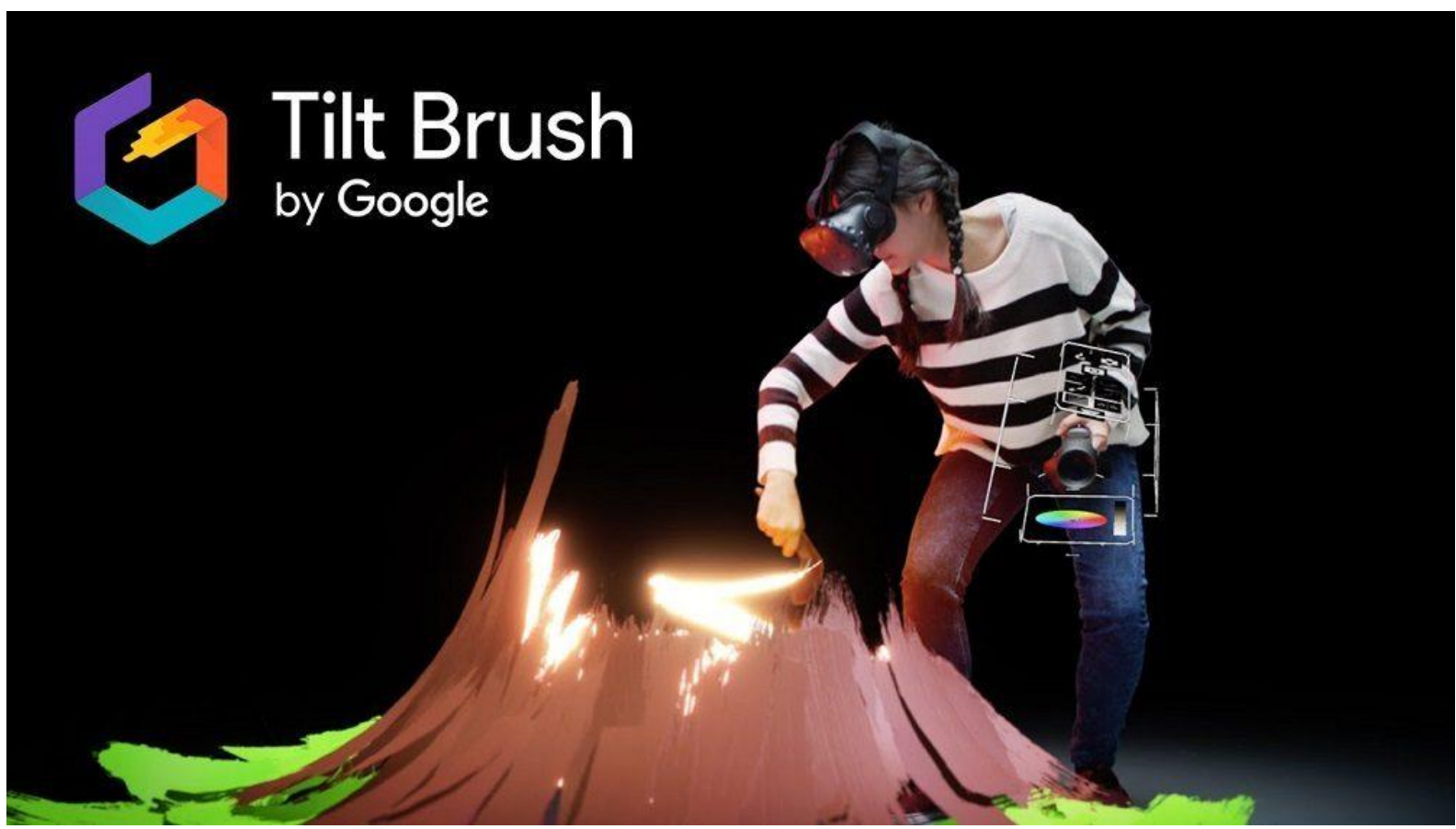

Figura 25: Criação virtual a partir do app Tilt Brush. Fonte: https://www.tecmundo.com.br/realidadevirtual/113617-tilt-brush-google-torna-open-source-plataforma-pintar-vr.htm. Acesso: 10/12/2017.

A galeria de arte Ontário (Toronto - Canadá) abriu uma exposição que segue a tendência de interatividade, imersão e observação mediados. A Reblink (6 de julho de 2017 a 8 de abril de 2018), do artista digital Alex-Meyhew apresenta obras clássicas que, quando observadas através de um app instalado em celular ou tablet, literalmente saltam da tela. Esta é uma aplicação de outra tecnologia recorrente do século XXI, a realidade aumentada. 


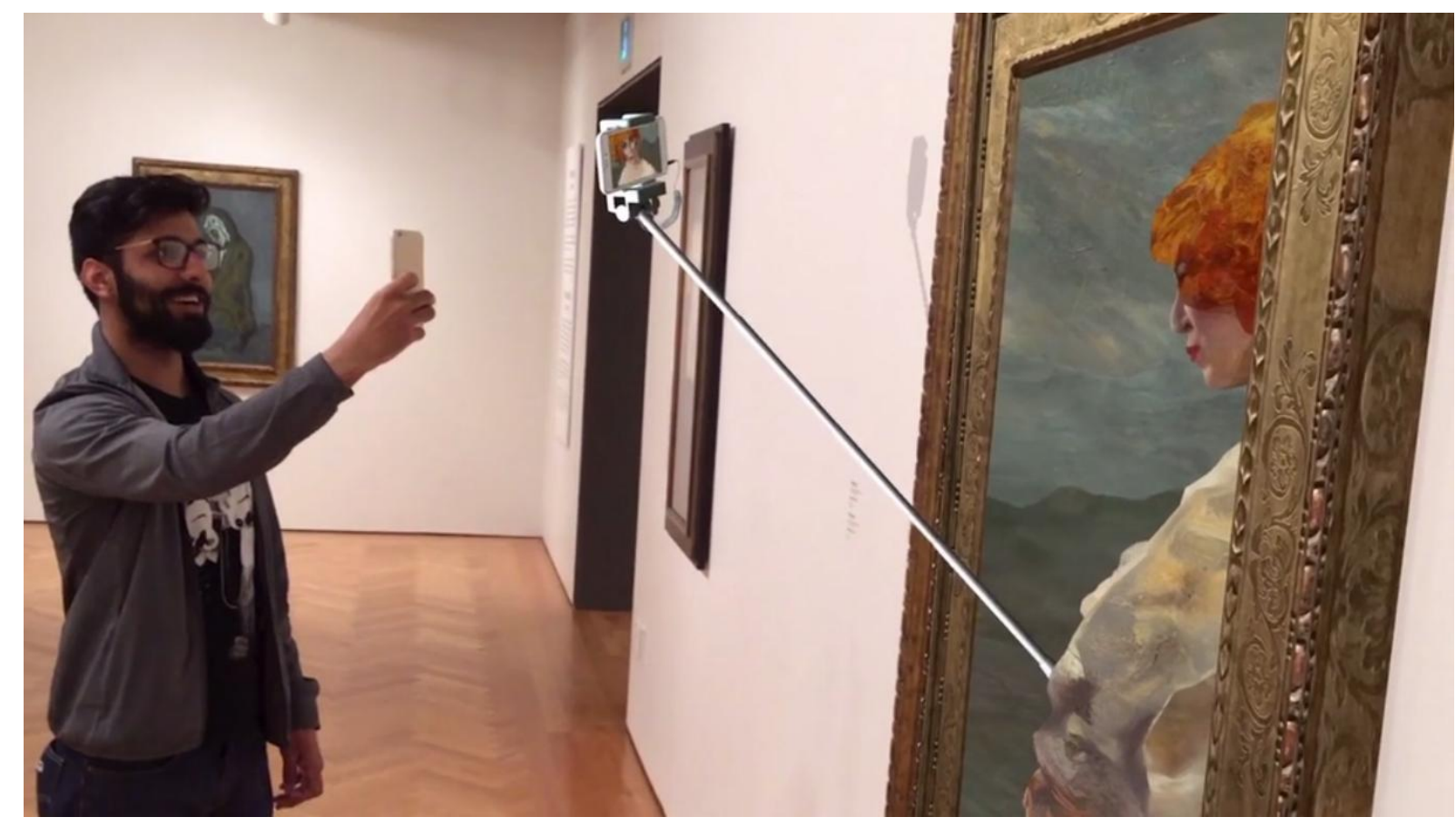

Figura 26: Imagem retirada do vídeo de apresentação da exposição Reblink. $O$ vídeo demonstra como as imagens dos quadros se apresentam a partir da observação mediada pelo celular. Fonte:

https://www.ago.net/reblink. Acesso: 10/12/2017.

A cada momento, novas tecnologias são criadas e apropriadas por artistas com a proposta não só de criticar e compreender esse novo ambiente tecnológico, mas também inserir o público em suas obras. O observador deixa de ser passivo e torna-se ativo e participante. Essa participação dá continuidade à obra, expandindo o universo conceitual artístico, e esse fenômeno é essencial para compor a arte transmidiática.

\subsection{Arte Digital/Arte Mídia}

A arte digital pode ser conceituada como um agrupamento de manifestações artísticas criadas por computador. Entretanto, nem toda imagem digital é uma obra de arte. Essa fronteira ainda é imprecisa, já que sua origem vem dos experimentos tecnológicos feitos a partir do advento do computador. Robert Kirsch, por exemplo, projetou em 1957 no SEAC (Standards Eastern Automatic Computer), um scanner que digitalizou a primeira fotografia do mundo, uma imagem de seu filho com três anos de Idade ${ }^{87}$. Apesar de pioneira, não é uma obra de arte.

\footnotetext{
${ }^{87}$ Considerada em 2003 uma das 100 imagens que mudaram o mundo pela Life Magazine.
} 
LIESER (2009) afirma que pode ser considerada arte digital a obra que possui linguagem visual midiática, metacríticas do meio e quando o recurso do computador ou internet para criar algo que não seria possível por outros meios.

Dentro do paradigma de uma pré-história da arte digital, exemplos interessantes surgiram a partir da experimentação de cientistas em parceria com artistas. O compositor Lejaren Hiller ${ }^{88}$ (1924-1994) e o programador Leonard Isaacson (1928-2016) programaram o computador ILLIAC $1^{89}$ para desenvolver o que seria a primeira peça musical criada por um computador. A peça Illiac Suit para quarteto de cordas contém quatro partes que correspondem a quatro experimentos musicais. Posteriormente, experimentos como esses serão importantes para a arte transmidiática, pois materializam a parceria entre a inteligência artificial do computador à imaginação do artista.

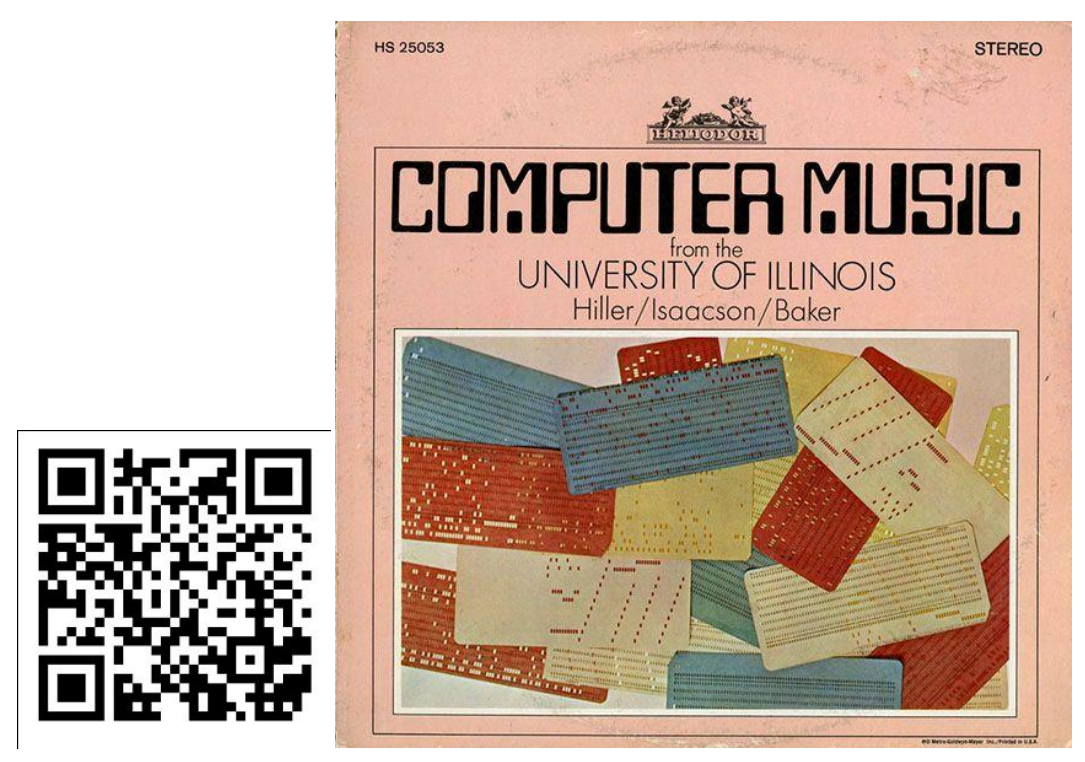

Figura 27: Capa do disco da peça Illiac Suit. Fonte: http://www.computerhistory.org/timeline/1956/ Para ouvir a primeira parte da obra utilize o QR code ao lado.

Em 1968 o Instituto de Arte contemporânea de Londres organizou uma importante exposição: a Cybernetic Serendipity ${ }^{90}$, um evento internacional que configurava obras de música, literatura, dança, escultura e animação feitas com apoio de computadores. No mesmo ano em Berlim, foi organizado um simpósio e

\footnotetext{
${ }^{88}$ Hiller fundou o Centro de Música Experimental na Universidade de Illinois - EUA.

${ }^{89}$ Computador construído pela Universidade de Illinois (e o primeiro a realmente pertencer a uma universidade), inspirado no EDVAC de Von Newmann.

${ }^{90}$ http://cyberneticserendipity.net/
} 
exposição sobre arte digital pelo Instituto Tecnológico de Massachusetts e pela Universidade Técnica de Berlim. Em 1970, a diretora de uma galeria em Hanôver organizou, em parceria com o Goethe Institut, uma exposição internacional itinerante. Esses são apenas alguns exemplos da agitação que a arte feita através das máquinas computacionais trazia ao universo artístico, a partir da década de 60, e que teve seu primeiro pico nos anos 70 (LIESER, 2009).

Essas pesquisas sobre arte digital espalharam-se pelo mundo. Pode-se citar entre os pioneiros; Hiroshi Kawano no Japão, Michael Noll nos Estados Unidos, Georg Nees na Alemanha, Jasia Reichardt no Reino Unido e Vera Molnar na França. Mas, sobretudo, deve ficar claro que muitos estudos e teorias desenvolvidos na década de 60 eram feitos por matemáticos, filósofos e cientistas que tinham acesso às grandes máquinas e estavam curiosos em explorar as fronteiras que esse novo meio proporcionava.

Em 1971 foi publicado o primeiro livro sobre arte digital, ComputergrafikComputerkunst (Gráficos por computador, arte por computador), por Herbert W. Franke (1927-), um artista que estudou matemática, filosofia, química, física e psicologia. No livro, visionariamente, ele afirma: "A arte por computador, talvez ou precisamente, porque se encontra no seu início, é algo mais que uma simples moda passageira. É mesmo possível que seja um elemento determinante na arte do próximo milênio" (FRANKE in. LIESER, p. 26)

Entretanto, a arte digital ainda sofria resistência e crítica. A exposição pioneira realizada por um museu foi de Manfred Mohr, no Museu de Arte Moderna de Paris. Durante uma conferência sobre a mostra na universidade Sorbonne ele foi duramente criticado e atiraram-Ihe tomates por utilizar uma máquina capitalista. (LIESER, 2009)

Também é importante enfatizar que o desenvolvimento da arte digital não decorreu divorciado da história da arte; o Dadá e a Arte Conceitual foram importantes influências. (PAUL, 2015)

Foi com o advento da acessibilidade dos computadores, na década de 80 que esta tecnologia pôde ser empregada por um amplo espectro de artistas. Pode-se citar como exemplo as instalações luminosas programadas do Alemão Otto Piene (1928-) e as esculturas de arte performática de laser ao ar livre dos artistas 
americanos Norman Ballard (1950-) e Joly Wulke (1948-) ${ }^{91}$. Também iniciou-se a pesquisa artística com robótica. Um pioneiro, Norman White (Canadá), apresentou seu Helpless Robot.

No início dos anos 90, o mercado artístico ainda via a arte digital com reservas. Há de se entender que, apesar das pesquisas com computador antecederem os anos 60 e os computadores pessoais da IBM e da Machintosh já residirem em muitos lares, essa tecnologia era muito nova e pouco compreendida. Da mesma forma sofreu a fotografia no início do século. Reprodutível e produzida por uma máquina, não era considerada arte.

As exposições tecnológicas com instalações interativas fugiam drasticamente dos cânones da arte tradicional e consequentemente sofriam preconceito tanto do público quanto da crítica especializada

A World Wide Web, rede aberta para o público em 1993, veio revolucionar tanto a comunicação quanto os meios artísticos. Esse meio não hierárquico abriu as possibilidades de divulgação e circulação do objeto artístico.

No século $\mathrm{XXI}$, a arte digital ganhou campo progressivamente. Atualmente são mais comuns instalações com tecnologia computacional, utilização de jogos virtuais, programas gráficos e exposições específicas para o meio. Também os artistas têm mais acesso aos equipamentos, não mais se limitando ao computador: celulares e tablets, que permeiam o cotidiano do público, são tecnologias apropriadas para manifestações artísticas.

Por fim, entre os movimentos contemporâneos da arte digital é valido mencionar:

- Net art: produzida para a internet, normalmente é colaborativa e interativa e utiliza diversas linguagens do meio como botões, links, transferência de dados em tempo real. O termo foi cunhado pelo artista Vuk Cosic em 1995. É crítica e política (ativista), refletindo o fluxo de mudanças da atualidade.

- Software art: quando o próprio artista é programador. O software é executável em um computador que não necessariamente está conectado a internet.

${ }^{91}$ lbid, p. 173-174. 
- Hacktivismo: o artista escreve o código fonte e manipula bits para confrontar as relações de poder econômico e político. Muitas vezes é considerado crime cibernético, pois interfere em sites e às vezes revela ao público informações sigilosas. Entretanto não é necessariamente criminoso, havendo diversas ações inofensivas. 


\section{Arte e transmídia}

Como já foi visto, transmídia não é necessariamente um conceito novo, mas foi a tecnologia digital que o fez florescer em todas as áreas. Pouco a pouco, as principais mídias convergiram para a internet, facilitando a troca de experiências, gerando fluxo de informações e conhecimento através da conectividade. Segundo JENKINS (2009), apesar de esse cenário ser proporcionado pela tecnologia, a convergência é essencialmente cultural.

A palavra convergência aparece com frequência na pesquisa sobre transmídia, entretanto não é inédita dentro do universo artístico. Sempre que se fala em poéticas que caminham para um mesmo ponto, pode-se aplicar o termo convergência. Entretanto, o termo, muito utilizado em comunicação, relaciona-se a três fenômenos: cultura participativa, convergência dos meios de comunicação e inteligência coletiva. (JENKINS, 2009)

A cultura participativa ocorre quando o receptor das informações não está satisfeito apenas em absorvê-las, mas interage disseminando, opinando e complementando o conteúdo. A convergência dos meios acontece na adaptação das mídias para a internet. Já a inteligência coletiva, potencializada pela internet, faz com que diversas pessoas, com formações diferentes e culturas diversas, criem um conteúdo complementar transdisciplinar.

Algumas tecnologias midiáticas e de comunicação como a fotografia, o cinema e o computador, não foram criadas, a princípio, com fins artísticos. Foram desenvolvidos em um contexto capitalista de produtividade e racionalidade em ambientes industriais, como visto no capítulo 1 (MACHADO, 2007, p.10). Entretanto, artistas ao redor do mundo se apropriaram de tais tecnologias como ferramentas de suporte do pensamento para comunicar e expressar sua poética. (PLAZA, 2003, p.65)

Atualmente, criações híbridas, multiplatafórmicas e interativas, que podem ser chamadas de transmidiáticas estão cada vez mais presentes no portfólio dos artistas, que passaram a repensar sua poética através dos novos meios tecnológicos. A obra transmidiática é fragmentada, distribui-se em múltiplos meios, 
desafiando o observador a seguir direções colocadas pelo artista para a descoberta, experiência e interpretação. Todos esses fragmentos convergem para o discurso proposto pelo artista e as obras transcendem o espaço comum da criação convencional (de concepção isolada, típica da pintura e da escultura, por exemplo) expandindo suas fronteiras. Muitos destes projetos são colaborativos permitindo ao público interação e mesmo alteração dos mesmos, colocando em xeque a própria ideia de autoria no sentido tradicional.

Essa interação pode não acontecer propriamente em um ambiente fechado de museu, mas através da web ou em diferentes pontos de acesso por meio das tecnologias móveis. Neste contexto, os projetos tornam-se transmidiáveis, ou seja, qualquer indivíduo que tenha acesso a eles, seja por um museu virtual, Youtube, Facebook ou Instagram pode usar o arquivo digital para ressignificá-lo, modificá-lo, ampliá-lo. Nesse caso, a obra transmídia, concebida ou não pelo autor para processos interativos, agrega outros artistas que dão continuidade ao conceito original da obra, ampliando-a a partir de outras localidades ou outros meios, dando seguimento à criação original e tornando-a híbrida.

Essa transmidiação é, atualmente, mais comum do que se pode imaginar. Pode-se usar como exemplo a transmidiação a partir de uma pintura renascentista: O vídeo "Moça com brinco de pérola" é uma adaptação do livro do mesmo nome escrito pela autora inglesa Tracy Chevalier (1962-). A história tem como base o quadro "Moça com Brinco de Pérola" (óleo sobre tela, ca. 1665) de Johannes Veermer (1632-1635), e recria o universo do pintor holandês, com destaque especial para seu atelier. Suas pinturas ganham vida e movimento no filme, e transformam-se em música a partir da criação de Alexandre Desplat (1961-), compositor francês selecionado para criar a trilha sonora do filme. A pintura foi expandida para texto, filme e música.

A artista e compositora Mieko Shiomi, já citada no subcapítulo sobre intermídia, identifica a transmidiação em sua própria obra a partir do momento em que outros artistas usam múltiplos meios tecnológicos para ampliar seu universo poético. Esse exemplo pode ser citado como uma arqueologia da transmídia artística, já que precede o próprio uso do termo. 
A obra que faz parte da Fluxusfilms, Disappearing Music for Face (1964), teve sua primeira apresentação na Washington Square Gallery em Nova lorque, organizada por George Maciunas (1931-1978, fundador do grupo Fluxus). A performance tinha a instrução "sorria e faça desaparecer gradualmente" (Smile, and make it disappear gradually) e teve que ser auxiliada por Alison Knowles (1933-), também integrante do grupo Fluxus, pois o inglês de Mieko era insuficiente para a apresentação.

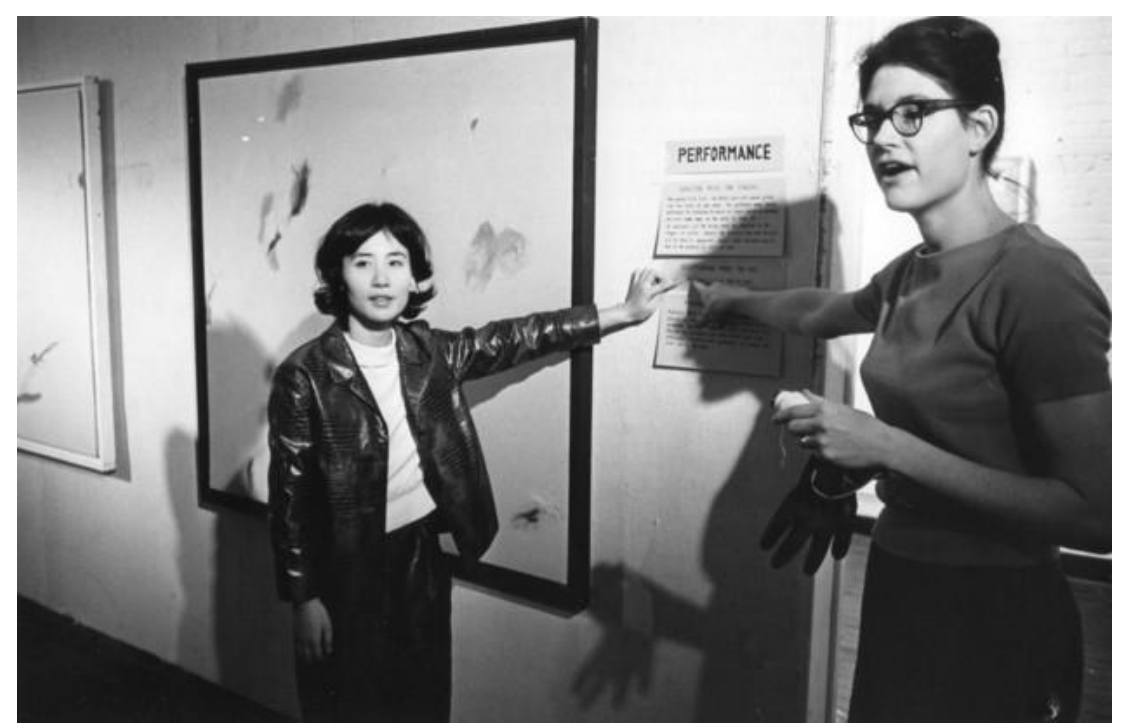

Figura 28 Shiomi Mieko e Alison Knowles durante a apresentação de Disappearing Music for Face, na Washington Square Gallery em Nova lorque. Foto de Peter Moore. (C) Barbara Moore / Licenciado pela VAGA, NYC. Disponível em http://post.at.moma.org/content items/241-intermedia-transmedia. Acesso em $12 / 01 / 2018$.

Posteriormente, Peter Moore (1932-1993, fotógrafo) gravou um filme com Yoko Ono (1933-) sorrindo, o Disappearing Music for Face (Fluxfilm no. 4), em 1965. Maciunas transformou o vídeo em um flip book ${ }^{92}$, com 39 fotografias extraídas do vídeo em que a ilusão do sorriso vai desaparecendo à medida que as páginas são vistas rapidamente em sequência. Em 2002, Mieko compôs Smiling music, inspirada em Disappearing Music for Face, a pedido de Michele Edwards (musicologista de Minnesota/EUA).

\footnotetext{
${ }^{92}$ Flip book é um pequeno livro de imagens sequenciais que, ao ter as páginas viradas rapidamente, cria a ilusão de movimento das imagens.
} 


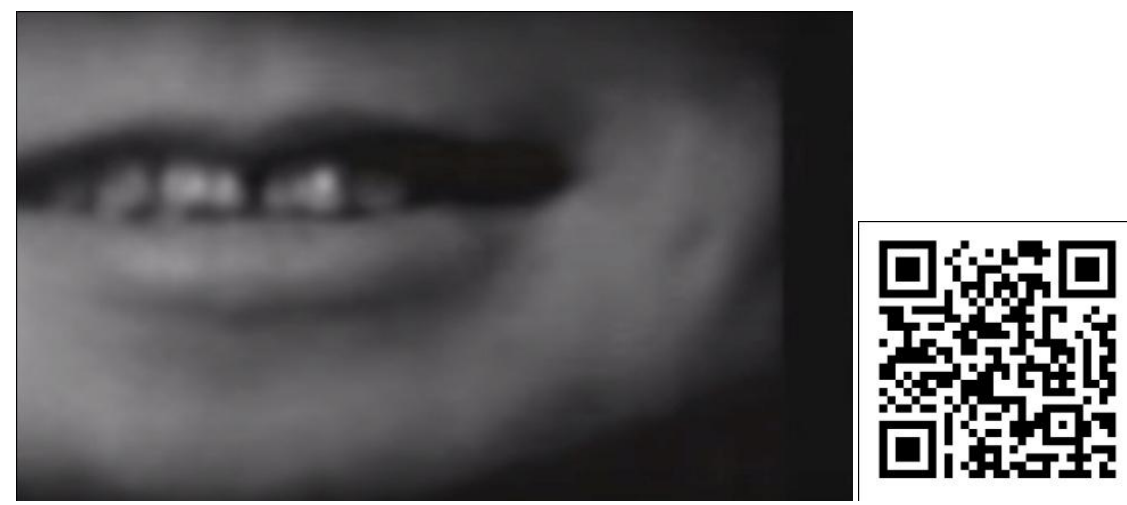

Figura 29 Imagem do filme Disappearing Music for Face (FluxFilm no. 4), 1965, gravado por Peter Moore, interpretado por Yoko Ono, produzido por George Maciunas. A imagem foi retirada do vídeo veiculado no Youtube, disponível em https://www.youtube.com/watch?v=9qAjQVKQgUQ, Acesso em 12/01/2018. No QR code ao lado é possível assistir ao vídeo.

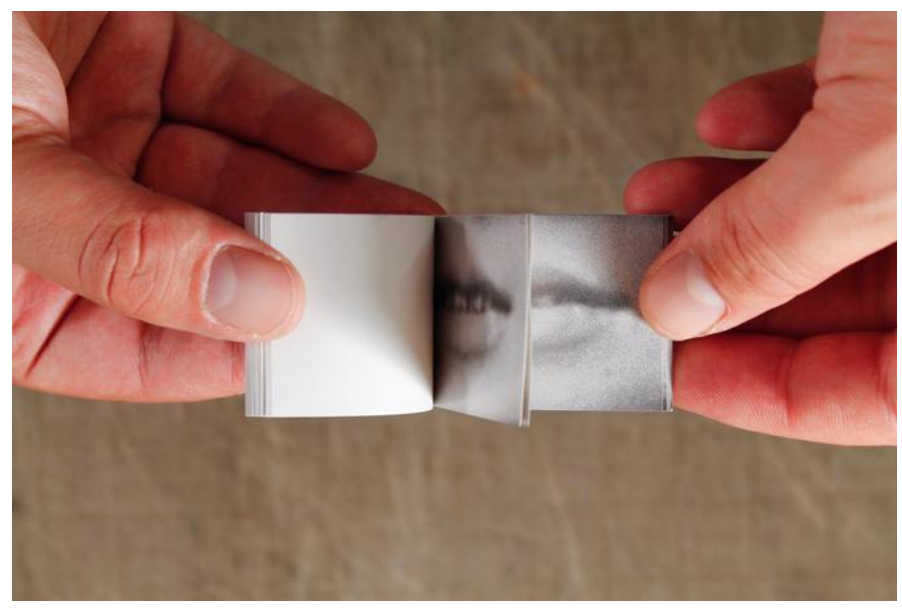

Figura 30 Flipbook do filme Disappearing Music for Face (FluxFilm no. 4), Disponível em: https://www.printedmatter.org/catalog/14792/. Acesso em 12/01/2018.

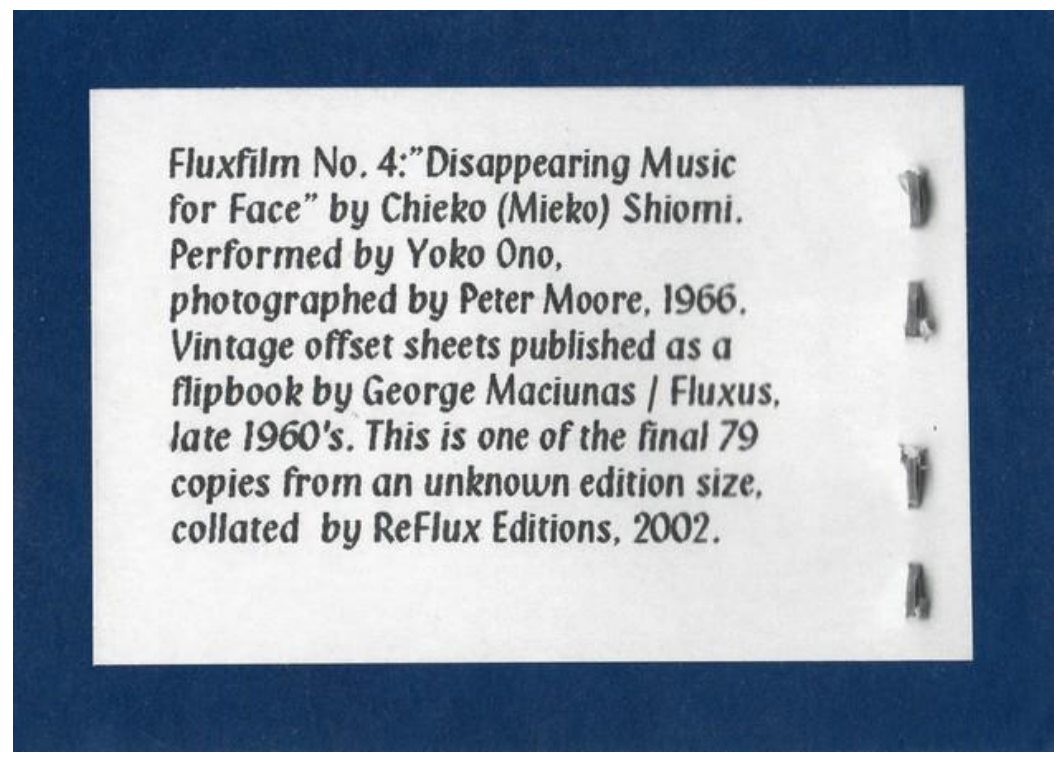

Figura 31 Página final do Flip Book "Disappearing Music for Face". Nesta página se concentram os créditos da obra criada por Shiomi Mieko, interpretada por Yoko Ono e fotografada por Peter Moore. Essa edição foi impressa em 2002. Imagem disponível em http://post.at.moma.org/content_items/241-intermedia-transmedia\#Fig 5-8 jump. Acesso em $12 / 01 / 2018$. 
De acordo com a artista, o processo transmidiático de sua obra foi iniciado por Maciunas, entretanto, a obra continua em movimento. Mieko abraça a ideia de sua obra transmidiada com entusiasmo, como pode ser percebido pela afirmação abaixo. Para ela, a transmídia mantém a obra viva e em constante evolução, podendo ser reinventada e transferida para outros meios com o passar do tempo. "[...]. Hoje, depois de uma pausa, gostaria que algumas pessoas realizassem uma nova versão complexa de Disappearing Music for Face”. (MIEKO, 2013)

Outro exemplo interessante de obra transmidiada está no trabalho de Van Gogh (1853-1890). Na FILE de 2016, o artista americano Mac Cauley criou um ambiente virtual em três dimensões para ser explorado com óculos de VR na obra "The Night Café". O observador se desloca pela obra, em imersão completa $360^{\circ}$, e aproxima-se dos personagens e objetos como se fizesse parte do quadro.

A grande novidade no universo estético do artista foi o vídeo "A paixão de Van Gogh", que estreou em novembro de 2017. Dirigido por Dorota Kobiela e Hugh Welchman o filme mescla atores, pinturas e computação gráfica. A animação, toda pintada a mão, levou cinco anos para ser produzida e se passa um ano após a morte do pintor. A história é contada através das obras criadas por Van Gogh dando vida e movimento a locais e personagens pintados ${ }^{93}$.

\footnotetext{
${ }^{93}$ Correio Brasiliense. Animação 'A paixão de Van Gogh' estreia nos cinemas europeus. Disponível em: http://www.correiobraziliense.com.br/app/noticia/diversao-e-arte/2017/10/19/interna diversao arte,634699/filmeanimado-de-van-gogh.shtml. Acesso em 12/12/2017.
} 


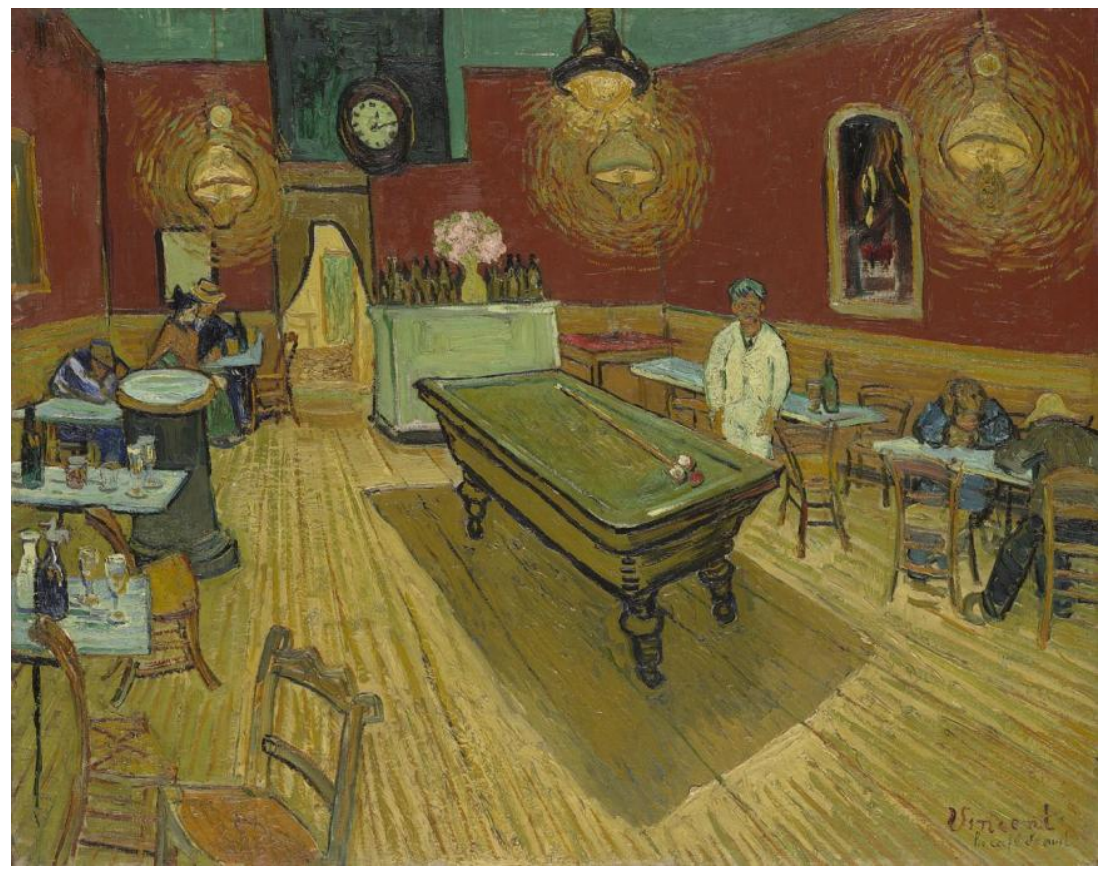

Figura 32: Le Café Nuit (The Night Café), Vincent Van Gogh, óleo sobre tela, 1888. Fonte: https://artgallery.yale.edu/collections/objects/12507

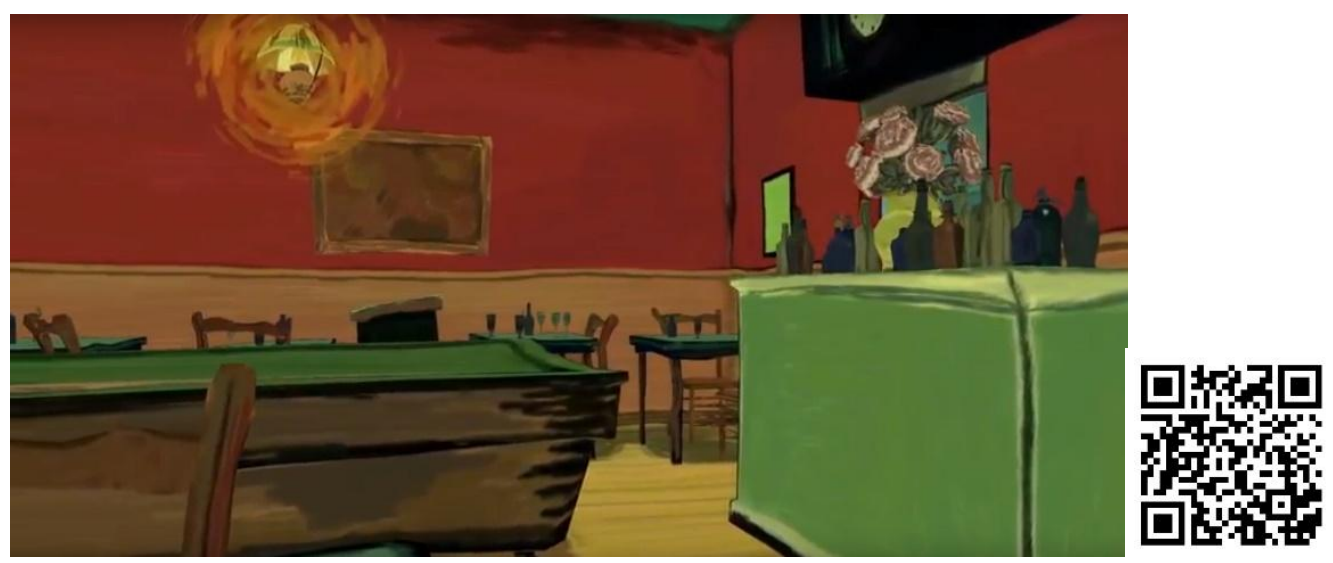

Figura 33: Imagem extraída do vídeo demonstrativo do ambiente virtual criado por Mac Cauley. Através do QR code é possível assistir ao vídeo da obra no Youtube. Fonte: https://www.youtube.com/watch?v=IJKh3prqBal 


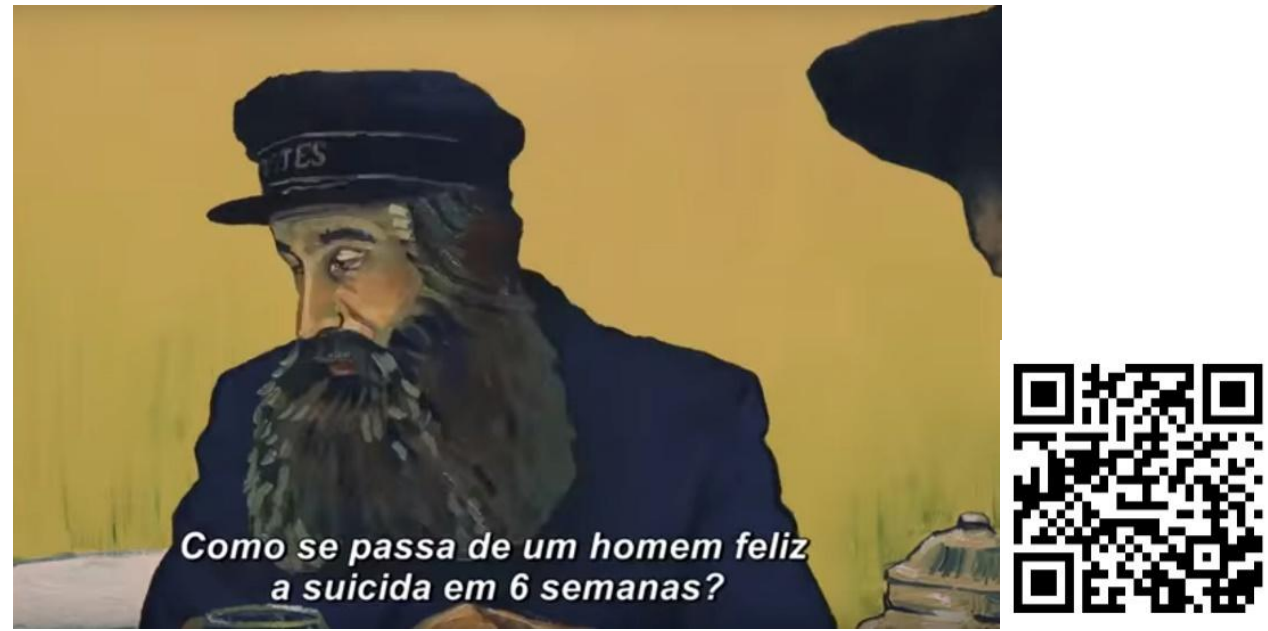

Figura 34: imagem do trailer do filme "A paixão de Van Gogh", de 2017. No QR code ao lado, é possível assistir ao trailer. Fonte: http://www.adorocinema.com/filmes/filme-241757/trailer-19557147/

Assim como a arte transmidiada cresce, a arte criada para ser transmídia vem ganhando terreno internacionalmente. O festival anual em Berlim (Alemanha) Transmediale é um centro de exposição de obras transmidiáticas. Nascido em 1988 como VídeoFilmFest, tinha, a princípio, o objetivo de abrir espaço para filmes que não participavam do escopo do circuito de festivais de cinema. Nos 30 anos que se seguiram evoluiu para um centro de divulgação, apresentação, discussão e crítica de arte midiática.

Para elucidar o conteúdo do evento, toma-se como exemplo a obra transmidiática “Ritual Causality 003" (2017), do coletivo Black Quantum Futurism (composto por Rasheedah Phillips e Moor Mother). Conceitualmente a obra combina física quântica, tradições culturais africanas e futurismo refletindo sobre consciência, tempo e espaço. É uma performance que desconstruiu temporalidades lineares através de projeção de imagens e textos e experiências de sons ao vivo. A obra critica a marginalização de certos núcleos da população em um mundo de alta tecnologia e combina ficção científica com conceitos africanos de tempo, ritual e som $^{94}$.

\footnotetext{
${ }^{94}$ Conforme explicação do catálogo on-line do evento de 2017
} 


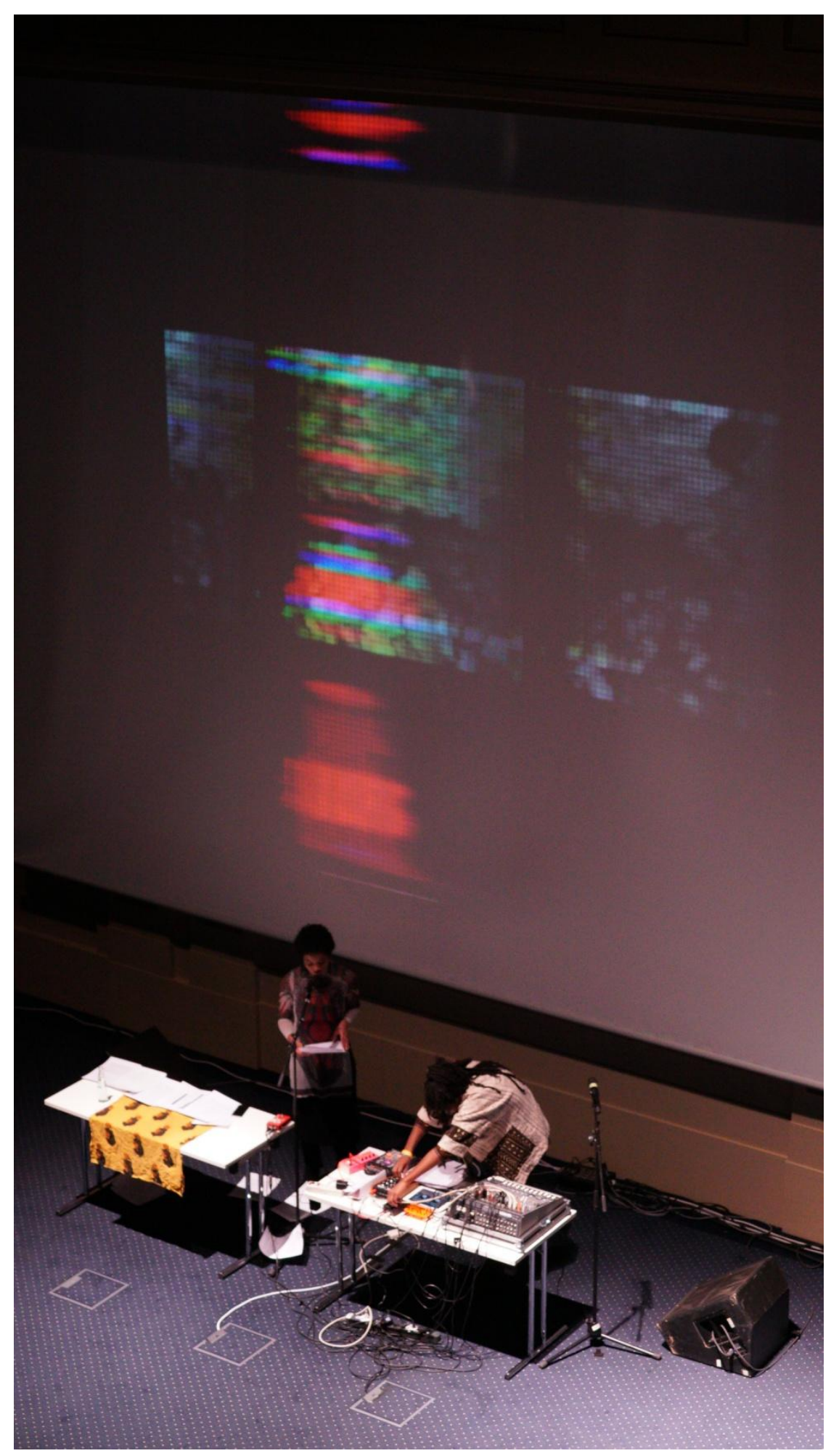

Figura 35 Rasheedah Phillips \& Moor Mãe realizando "Ritual Causality 003", 2017, festival Transmediale. Disponível em: https://transmediale.de/de/content/ritual-causality-003-0. Visualizado em 12/01/2018.

Esses exemplos de obras transmidiadas são muito interessantes na ampliação do conceito de transmídia artística. Para aprofundar esse estudo, foram 
selecionadas obras diversas, a partir do uso da tecnologia digital, elaboradas nos últimos 10 anos e que possuem em comum o uso de múltiplas plataformas para comunicar a ideia ou conceito artísticos.

Metodologicamente os critérios escolhidos foram:

- Intenção: a obra foi intencionalmente criada em transmídia pelos seus autores.

- Multiplataforma: o uso de múltiplas plataformas, tanto digitais como analógicas.

- Participação/Interatividade: a possibilidade de participação do público nas obras.

- Coautoria: apesar de algumas vezes idealizada por um único artista, artistas e cientistas participam do trabalho para viabilizá-lo tecnologicamente.

\subsection{Errar de Dios}

Na 31를 Bienal de São Paulo (2014) foi observado um exemplo interessante de obra multiplatafórmica: o grupo argentino Etecétera exibiu uma instalação participativa (Errar de Dios) onde, tendo como base a obra Palabras ajenas [Palavras alheias]: conversas de Deus com alguns homens e de alguns homens com alguns homens e com Deus (1967), de León Ferrari (1920-2012), é proposta uma crítica religiosa interativa que se constrói com diversos recursos visuais, sonoros, teatrais e literários. 

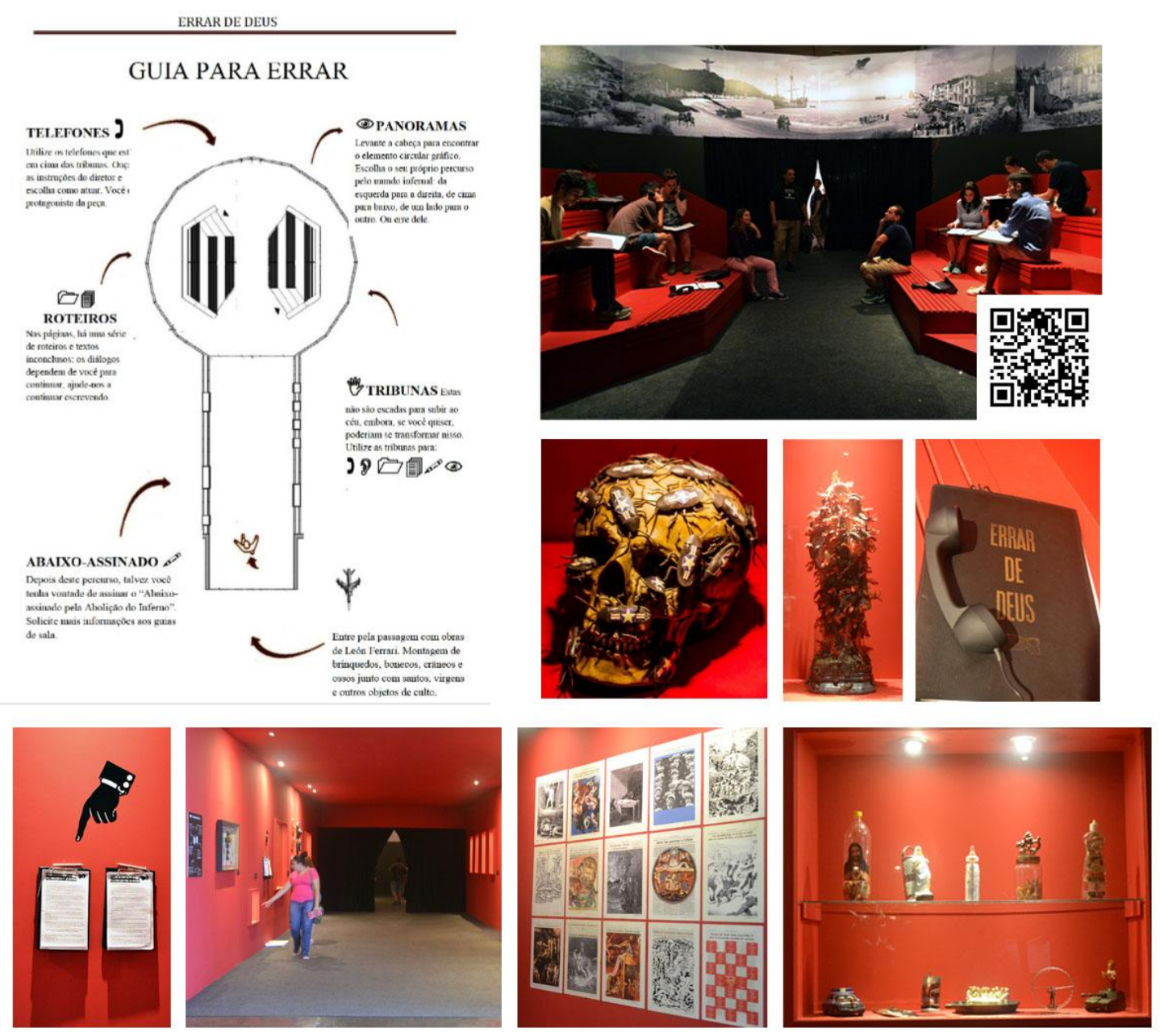

Figura 36: Algumas imagens da instalação participativa (Errar de Dios). Através do QR Code da imagem, é possível ouvir os sons gravados da instalação. Composição de fotos feitas na Bienal pela autora. $O$ esquema da instalação pode ser conferido em https://errardedios.org/textos-texts/, Acesso 01/03/2016.

Na entrada da instalação, colagens sobre edições de L'Osservatore (órgão oficial do Vaticano), esculturas montadas com santos e objetos de culto são colocadas em exposição cobertas de baratas de plástico ou montadas junto a brinquedos, como sugestão à interpretação do papel ocidental cristão em guerras e tragédias contemporâneas. Essas obras dividem espaço com a petição a ser enviada ao Vaticano, propondo a extinção do inferno. Nas pranchas dispostas junto à petição, há um breve texto explicativo bem como o abaixo-assinado, caso o observador se proponha a participar.

Ao entrar na sala do fundo, o visitante contempla, no alto, em um padrão circular, um diálogo com os afrescos de igrejas católicas. Entretanto, ao invés de imagens de santos, uma montagem fotográfica propõe a visualização de histórias trágicas que se repetem. No centro da sala circular, duas tribunas possuem 
telefones (que foram recolhidos das lixeiras da Bolsa de Comércio durante a crise de 2008) que simulam ligações.

O público participa e interfere na obra a partir dessas ligações. Ao atender, uma voz o "convida a atuar, repetir ou inventar. Aceitar com submissão ou desobedecer radicalmente" 95 . O que é dito ao telefone é gravado e, junto com outras declarações anteriores, é repetido em alto-falantes dentro da sala.

Depois o telefone toca novamente. Ao atender, o visitante ouve a seguinte gravação:

Bem-vindos ao inferno. Eis aqui o único protagonista: o grande Deus Capital. Força abstrata que se materializa e se apropria da vida para semear trevas na terra. Deus Econômico cheio de ambição, sois capaz de destruir países e nações, culturas e povos, de modificar geneticamente a natureza até transformar florestas em desertos, socavar os mares e perfurar montanhas até extrair o último fragmento mineral. Para nos deixar diante do nada; uma humanidade despojada de tudo. Deus Mercado que nos obrigais a competir até a morte para vos salvar. Deus Dinheiro que pondes preço a todas as coisas, à vida e à morte. Deus Patrão que nos explorais dia a dia e nos obrigais a vender nosso único recurso não renovável: o tempo. Deus Financeiro que especulais com nossa existência embargando o futuro de sociedades inteiras. Deus Político que nos enganais a cada quatro anos e nos fazeis viver iludidos em ditaduras democráticas. Deus Google que nos espiais, analisais nossos desejos, nossa ideologia e nosso comportamento. Endemoninhado Deus Capital, sois a tirania iracunda, única crença que ainda se sustenta, enquanto quase já não acreditamos em vós. Oh, Deus Capital, anunciai vosso fim de uma vez por todas e livrai-nos deste inferno econômico... ${ }^{96}$

Essa instalação transmidiática do grupo Etecétera é um exemplo de obra fragmentada e colaborativa, que usa diversas mídias diferentes convergindo para uma poética crítica. É também participativa ao colocar o visitante como coautor da obra, propiciando sua intervenção teatral, com a instalação e a gravação de sua voz, repetida depois para os próximos visitantes. Deve ser considerada transmidiática por utilizar múltiplas mídias complementares, imersão e participação.

\footnotetext{
${ }^{95}$ Texto retirando do site da obra em https://errardedios.org/errar-de-deus/ Acesso em 14/07/2016. ${ }^{96}$ Idem.
} 


\subsection{Pedro Paulo Rocha97, artista transmidiático.}

O artista Pedro Paulo Rocha não faz cerimônia ao se auto-intitular um artista transmidiático ${ }^{98}$. Para o artista, a tecnologia trouxe liberdade de criação, é ferramenta de desconstrução artística e torna as obras, além de participativas, abertas, podendo ser reinterpretadas ou reinventadas a qualquer momento. " $O$ artista transmidiático é um artista, é um furador de ondas, um percolador. Um...assassino de realidade, [...]é um virtualizador de virtualidade"99.

Em entrevista ${ }^{100}$, afirma que seu processo de criação transmidiática se iniciou com a ideia de cinema expandido e foi se fragmentando em inúmeras possibilidades. "[...] eu comecei a perceber que eu poderia criar máquinas abstratas, de puro sentido, sem nenhum tipo de fixação, como se fosse pichação, como se fosse uma 'fracterização"'. Quando questionado a respeito de quais mídias utiliza em sua obra ele responde entusiasticamente "Todas, né!"

\subsubsection{Pixel Pixo}

Entre seus projetos está o grupo Afactory ${ }^{101}$, composto pelos artistas Pedro Paulo Rocha, Caleb Mascarenhas (músico multi-instrumentista e produtor), Fernando Falcoski (multi-intrumentista, designer e produtor musical) e Danilo Barros (cineasta e VJ).

O Afactory cria processos transmidiáticos combinando cinema, vídeo, música, internet e mobilidade. Um exemplo da obra do grupo é "Pixel Pixo - Poesia Pixel" (2010), no geral o grupo combina performance, grafismos e música seguindo o trajeto de um grupo de pichadores nos bairros de periferia da cidade de São Paulo.

"É um amálgama de cores e tipologias riscando a cidade, passando de tela em tela, através de nomes e rostos anônimos, criando conexões possíveis de cidades invisíveis. Uma escrita em

\footnotetext{
${ }^{97}$ Cineasta, artista multimídia e pesquisador de transmídia e arte colaborativa, Pedro Paulo já teve suas obras expostas no MIS, no evento Matilha Cultural, na Mostra Live Cinema entre outros.

${ }^{98}$ Como pode ser visto em seu site https://pedropaulorochadotcom.wordpress.com/author/pedropaulorocha/. Acesso 12/12/2017.

${ }^{99}$ Segundo entrevista realizada dia 20/07/2016, na FUNARTE/SP, Alameda Nothmann, 1058 - Campos Elíseos, São Paulo.

100 Idem.

${ }^{101}$ https://afactorytransmidia.wordpress.com/o-grupo/
} 
movimento que transforma a cidade no ciberespaço de pixel e pixo"102.
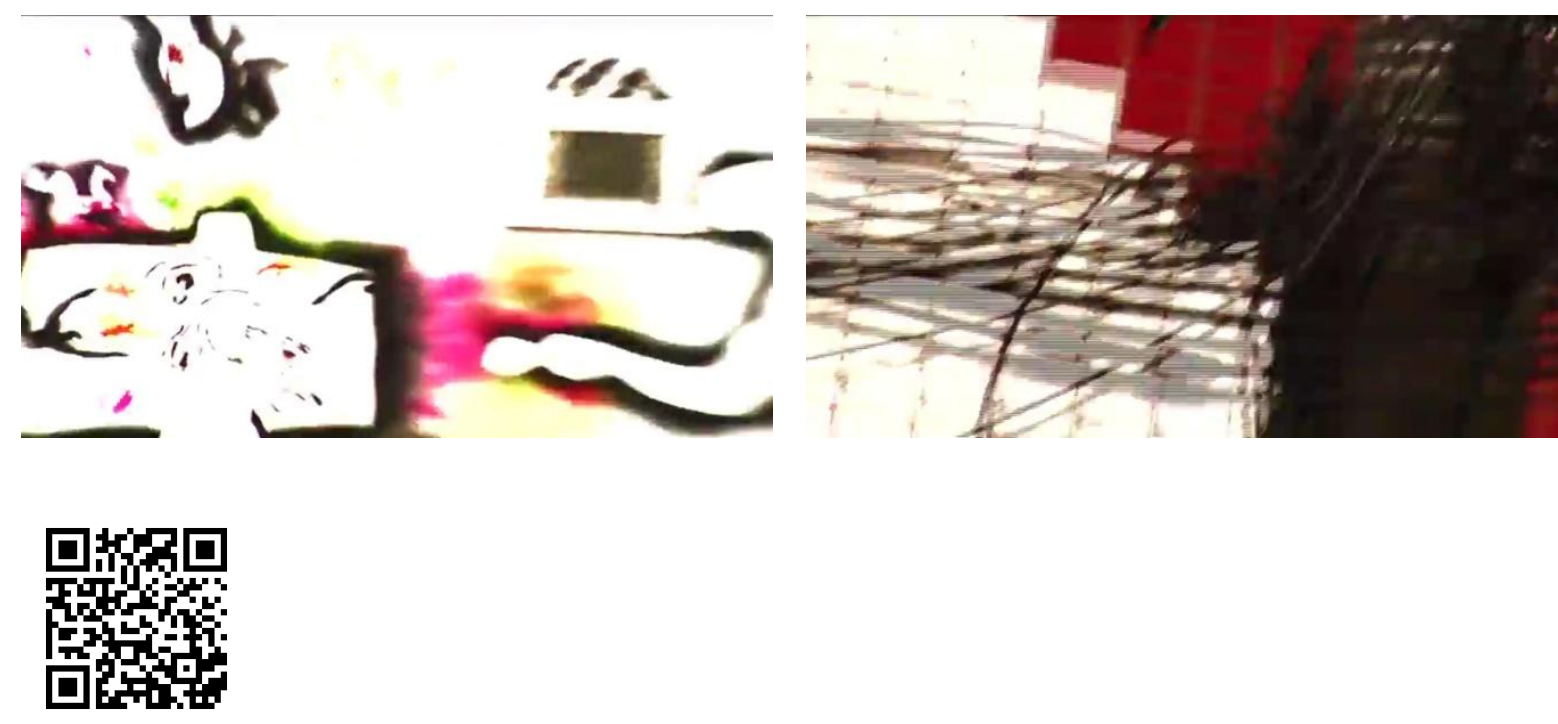

Figura 37: Imagens do Vídeo "Pixel Pixo - Poesia Pixel”. Através do QR Code abaixo, é possível visualizar um vídeo da performance. Disponível em: https://www.youtube.com/watch?v=gzMQ0IcVxzA. Visualizado em 5/7/2017.

Essa obra transmidiática se apropria da pintura dos muros da cidade e a desmaterializa através do vídeo, uma obra concreta em um muro deixa de ser tinta para transformar-se em pixel. Mistura palavras e imagens seguindo o trajeto de um grupo de pichadores, capta a arquitetura da periferia para depois ser projetada e sofrer interferência de performance, poesia e música ao vivo. Por fim, esse universo conceitual é colocado no ciberespaço, na internet, onde pode ser observada continuamente como uma pichação de pixels. Pode ser qualificada como transmidiática por ser composta de múltiplas mídias complementares, performance, música e texto.

\subsubsection{Kynemas Fluxuz Filmes}

Outra obra interessante de Pedro Paulo é Kynemas Fluxuz Filmes, uma obra aberta, em constante movimento, tendo novos vídeos anexados (produzidos por

\footnotetext{
102 Pixel Pixo - Poesia Pixel, apresentação do MIS disponível em http://www.missp.org.br/icox/icox.php?mdl=mis\&op=programacao_interna\&id_event=584
} 
diversos autores) e visualizados nas mídias sociais. Fluxuz combina personagens da rua pichando com laser, projeção, cinema, internet e performance.

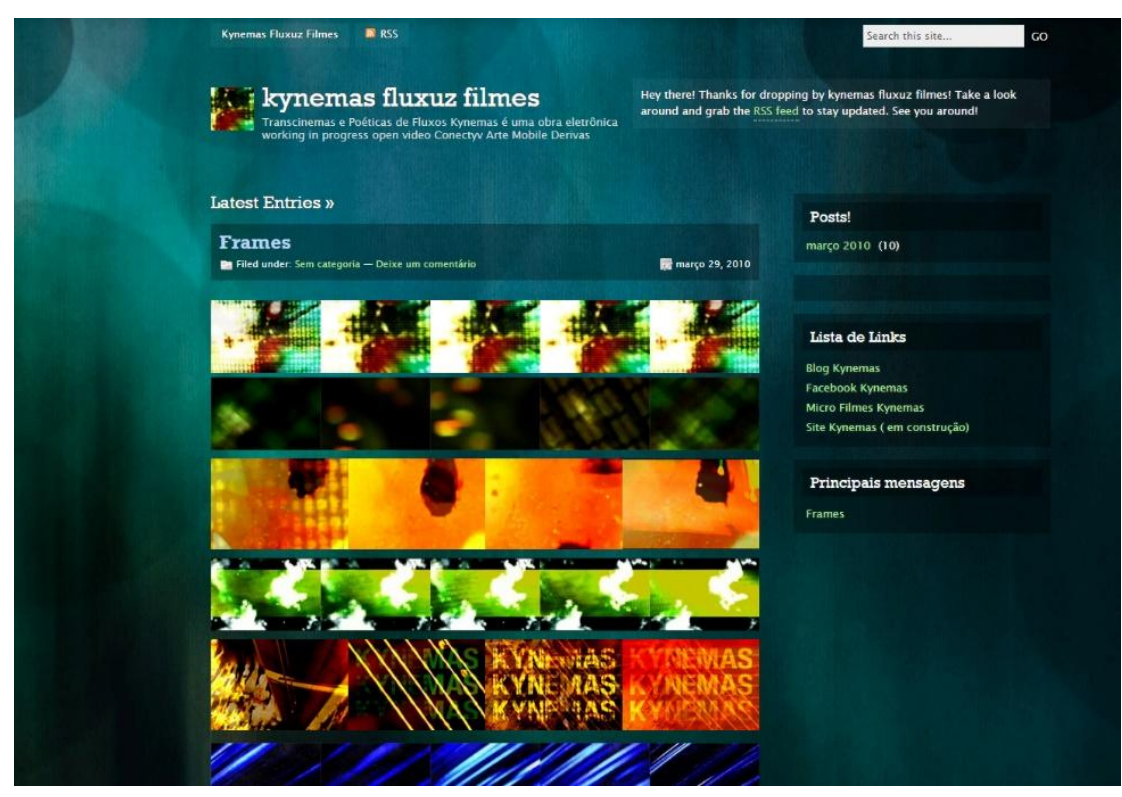

Figura 38: Site do Kynemas Fluxuz, com frames de diversos vídeos. Disponível em https://kynemasfluxuz.wordpress.com/. Acesso 12/12/17. 


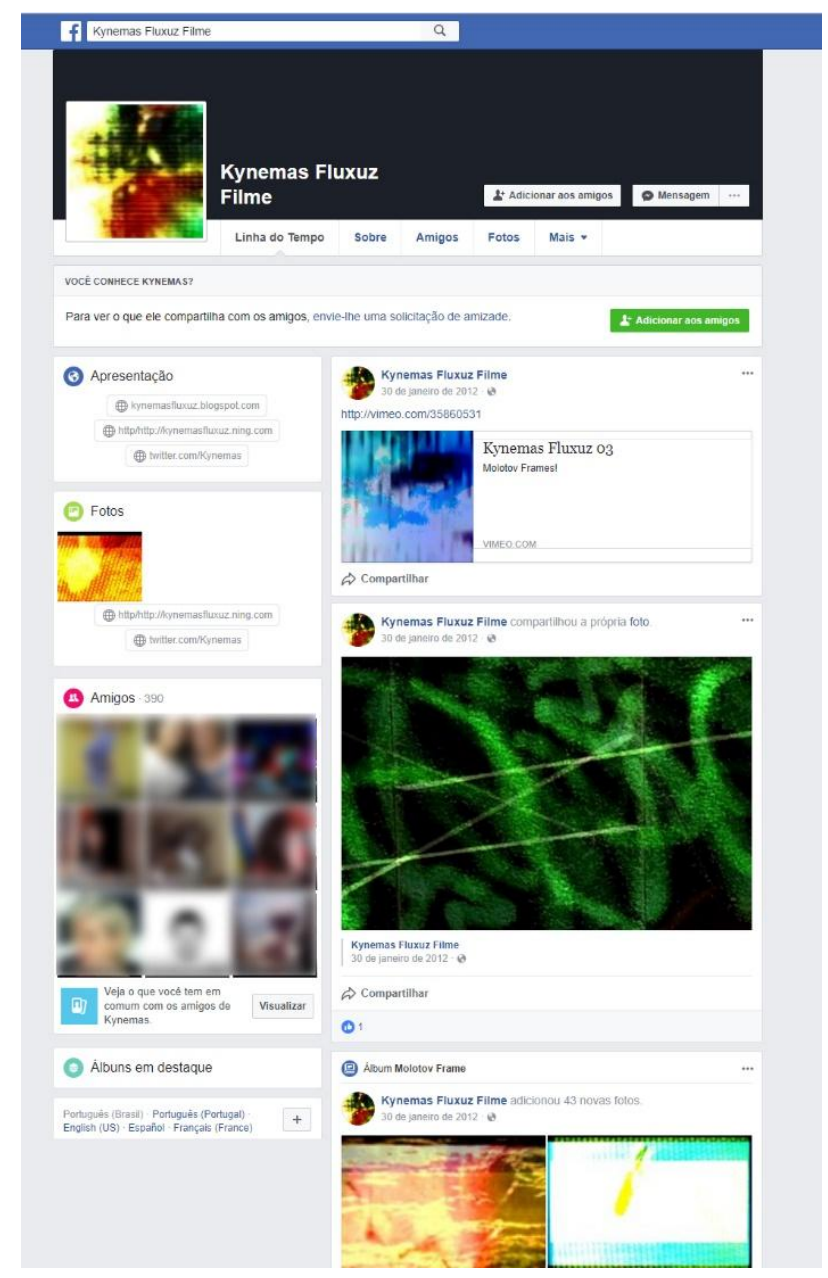

Figura 39: Kynemas Fluxuz no Facebook. https://www.facebook.com/kynemas.fluxuzfilme. Acesso em 12/12/17.

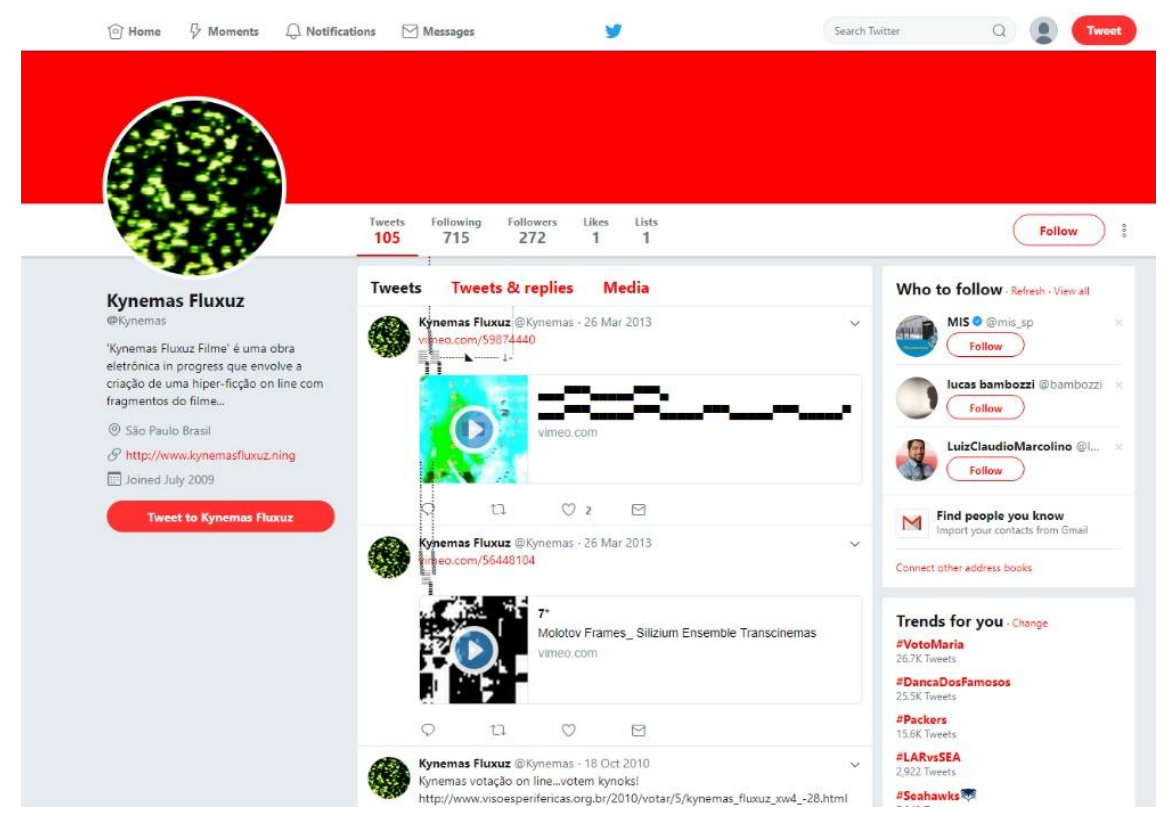

Figura 40: Kynemas Fluxuz no Twitter. https://twitter.com/Kynemas. Avesso 12/12/2016. 


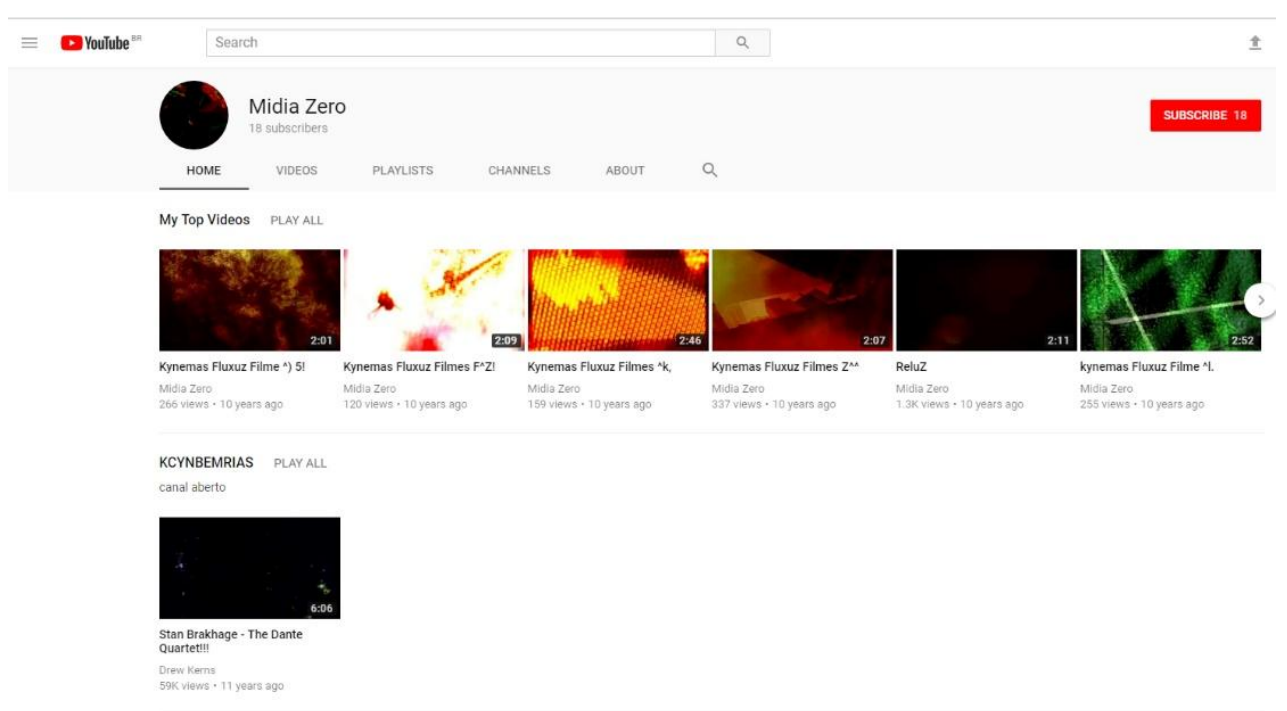

Figura 41: Kynemas Fluxuz no Youtube. https://www.youtube.com/channel/UCp0yttecLTg2yjddSPPb7oQ. Acesso 12/12/2017.

Essa obra híbrida tem como material inicial (matriz-chamada Flux-z) um filme disponibilizado na rede e, como um trabalho em constante processo, pode ser recriado de forma colaborativa, recombinando imagens e sons, colocando em movimento "uma poética arquitetônica de fluxos, um diagrama em transformação em que o cinema, o vídeo, o audiovisual se torna um meio de interface, de agenciamento, de conexão entre linguagens, pessoas e lugares"103. Cada versão pode misturar uma série de linguagens cinematográficas: roteiro, fotografia, música, cenas.

Cada ciclo da obra tem um roteiro virtual em que o público é convidado a participar da construção de uma "hiperficção"104, criando uma série de novas versões a partir da matriz. Esse processo colaborativo cria uma coautoria da obra com um constante fluxo de novas versões conectando pessoas de diferentes lugares. "Cada navegante é um personagem virtual do filme em constante transformação"105.

\footnotetext{
${ }^{103}$ Kynemas Fluxuz filmes, o projeto. Disponível em https://kynemasfluxuz.wordpress.com/sobre/. Acesso em 12/12/2017.

${ }^{104}$ Hiperficção, é uma literatura interativa produzida e disponibilizada em meios digitais (hipertexto). Sua narrativa é construída de forma colaborativa, criando múltiplas escolhas de sequência.

105105 Kynemas Fluxuz filmes, o projeto. Disponível em https://kynemasfluxuz.wordpress.com/sobre/. Acesso em 12/12/2017.
} 


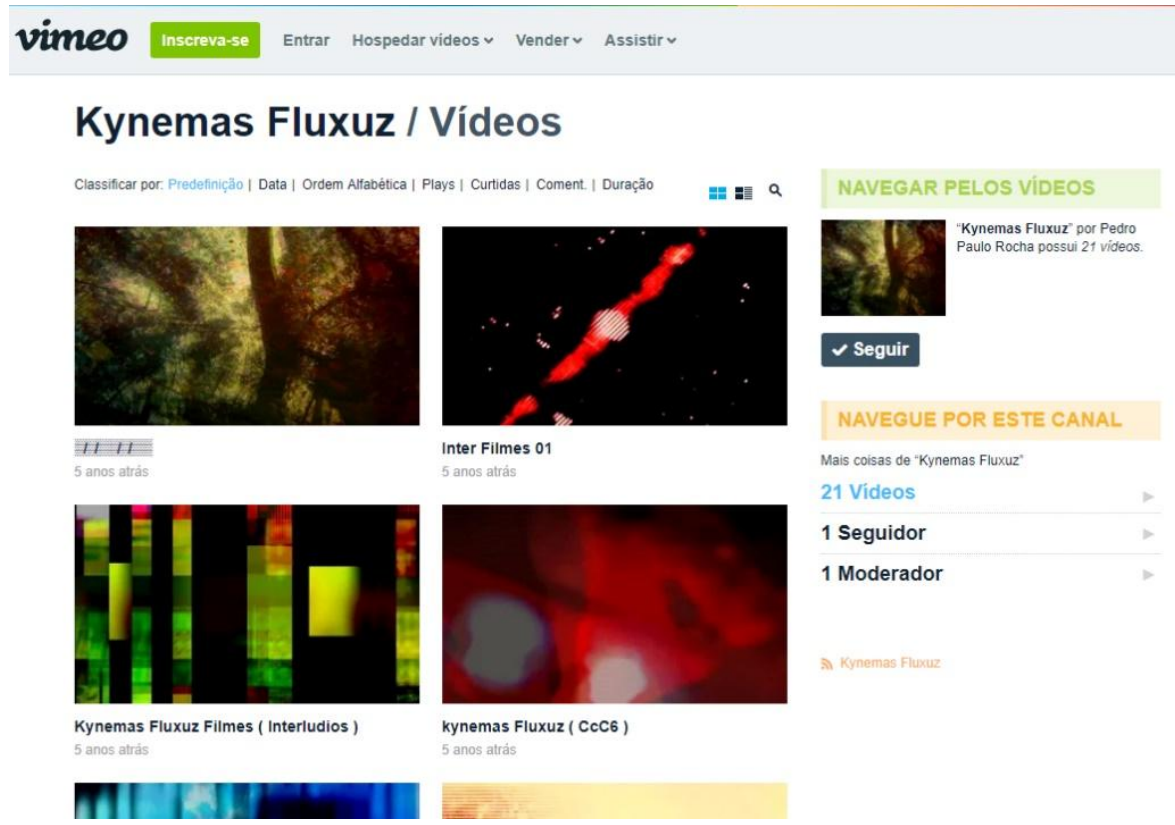

Figura 42: Kynemas Fluxuz no vimeo. Diversos filmes diferentes disponíveis.

https://vimeo.com/channels/284582/videos. Acesso em 12/12/2017.

A obra transmidiática já tem mais de 100 microfilmes espalhados pela web e, a cada 3 filmes assistidos pelo internauta, é enviado para o Twitter uma mensagem com textos e frames com links para assistir a novos fragmentos da história. A proposta é que os filmes circulem de forma viral pela internet. Além do uso de múltiplas mídias, é interessante ressaltar que a obra é participativa com diversos coautores, a ideia é que esteja em constante modificação e reinterpretação, mantendo um continuum infinito. Qualifica-se como transmidiática por combinar múltiplos meios midiáticos, participação, coautoria e música.

\subsection{Grupo ExCompanhia de Teatro}

\subsubsection{EU - Negociando Sentidos}

ExCompania criou uma obra transmidiática pioneira dentro da dramaturgia. $\mathrm{O}$ grupo é dirigido por Bernardo Galegale e Gustavo Vaz ${ }^{106}$, realizou uma experiência

\footnotetext{
${ }^{106}$ Bernardo Galegale é formado em ciências sociais pela USP, mestre em Mediação Cultural, artista transmídia e diretor. Gustavo Vaz é ator, locutor, artista transmídia e roteirista.
} 
transmídia em São Paulo e, posteriormente em Munique, envolvendo teatro, performance, happening e mídias sociais em 2012.

A peça "EU - Negociando Sentidos" é dividida em três atos, com encontros em três semanas seguidas. O público, após comprar o ingresso, começa a participar do enredo a partir de conversas com o casal Leonardo Gritzbur e Sofia Montillo (que estão mudando de Campinas para São Paulo) através das mídias sociais.
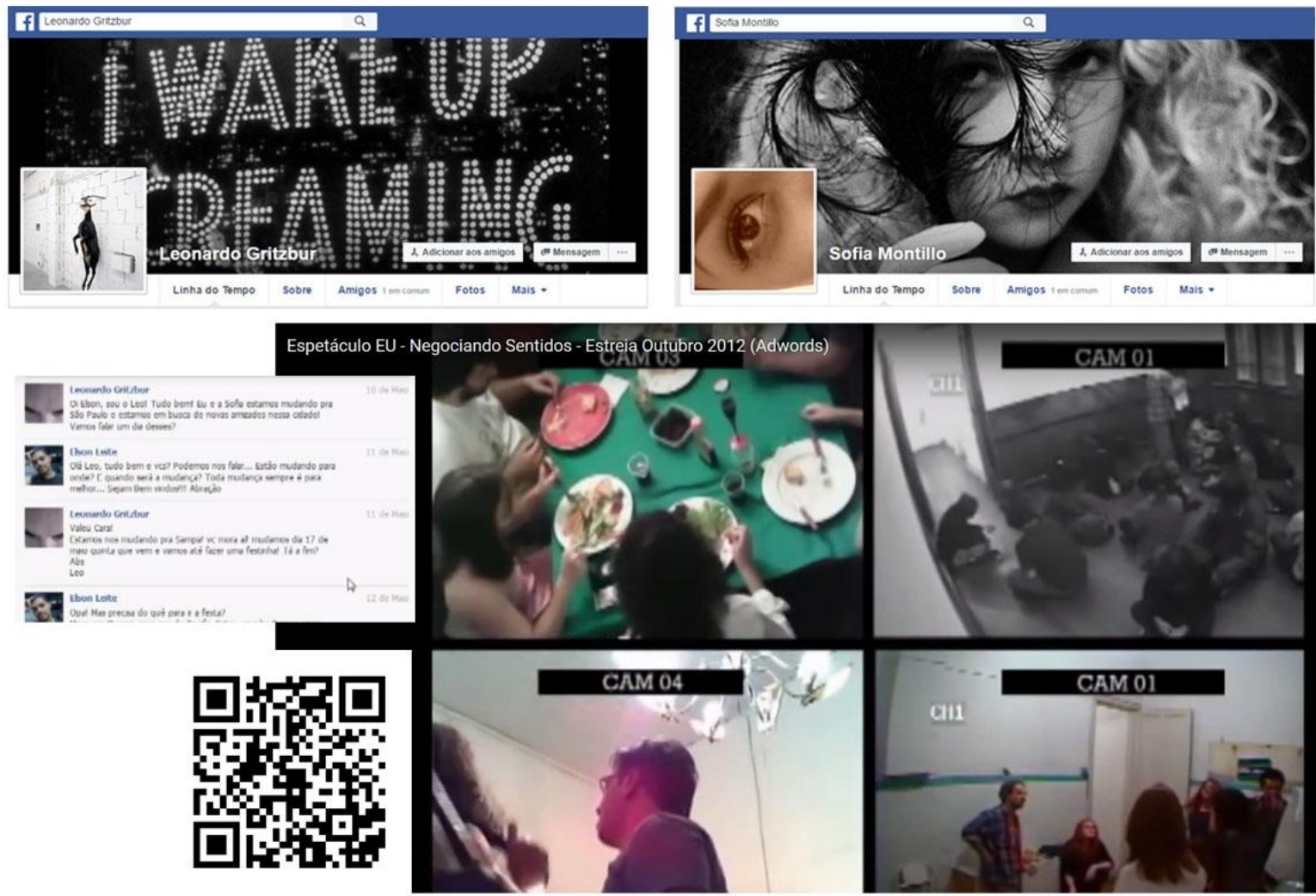

Figura 43: Acima: Perfis fictícios dos personagens de "Eu - Negociando Sentidos" no Facebook. Abaixo: Imagens das gravações feitas através de diversas câmeras colocadas dentro do espaço cenográfico da casa. Ao lado esquerdo, um exemplo de diálogo do espectador com as personagens. Através do $Q R$ code, é possível ver o vídeo explicativo de apresentação da peça. Fonte das imagens de câmera: https://www.guiadasemana.com.br/sao-paulo/arte/evento/eu--negociando-sentidos-teatro-do-centro-da-terra-1110-2012 Acesso 12/06/2016.

A primeira "apresentação" é uma festa (que, em São Paulo, ocorreu em uma casa no bairro da Pompéia). Apesar de ter um roteiro pré-definido, sofre alterações conforme o público interage com os personagens. 
Ao longo das três semanas da apresentação, os espectadores podem trocar e-mails, falar por telefone, twitter e Facebook ou até se encontrar com os personagens para um café fora do espaço cênico da casa. Desta forma o público, além de assistir ao drama entre os personagens principais, também torna-se personagem atuante na história. Por fim, todo o conteúdo gravado durante a peça será transformado em documentário.

Essa obra é transmidiática e participativa. Combina tecnologias (vídeo, computador e internet) com texto, teatro e performances. O roteiro não é fixo, apesar de ter uma linha condutora, e se desdobra a partir da interação com os espectadores nas redes sociais. Ligações telefônicas podem acontecer, bem como troca de emails e encontros físicos entre os personagens e o público.

A imersão na obra é tanta, que o público discute e se emociona a partir dos acontecimentos descritos pelas personagens. $O$ universo da obra envolve 0 espectador psicologicamente pela Web e por fim, fisicamente, no encontro final, onde participam e assistem à conclusão da história. É uma obra transmidiática por combinar múltiplos meios midiáticos, participação, teatro, texto e performance.

\subsubsection{O Enigma Voynich}

A mesma dupla criativa, o grupo ExCompanhia lançou em 2017 mais um trabalho dramatúrgico transmídia: O Enigma Voynich. Trata-se de um aplicativo gratuito para ser instalado no celular com o intuito de levar o espectador para dentro da peça.

O aplicativo combina ficção, áudio 3D e grafite digital. Utiliza a tecnologia binaural, uma gravação de som com dois microfones posicionados de forma a criar uma sensação de som estéreo 3D, simulando a sensação de se estar presente no local onde o som foi produzido. É uma tecnologia específica para ser usada com fones de ouvido para uma experiência tridimensional completa ${ }^{107}$. A ideia é manipular a percepção do ouvinte e simular um acontecimento ao vivo com sons realistas.

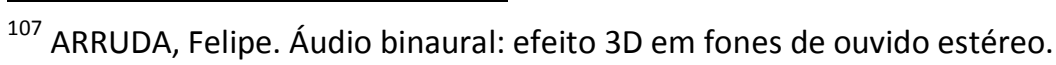


O artista Achiles Luciano foi responsável pelos desenhos de grafite digital, que não só situam o local da narrativa, mas informam a posição em que o espectador deve estar: de pé, sentado ou deitado. O audioespectador acompanha a história em primeira pessoa, representando o personagem José, um historiador e pesquisador do manuscrito Voynich ${ }^{108}$.

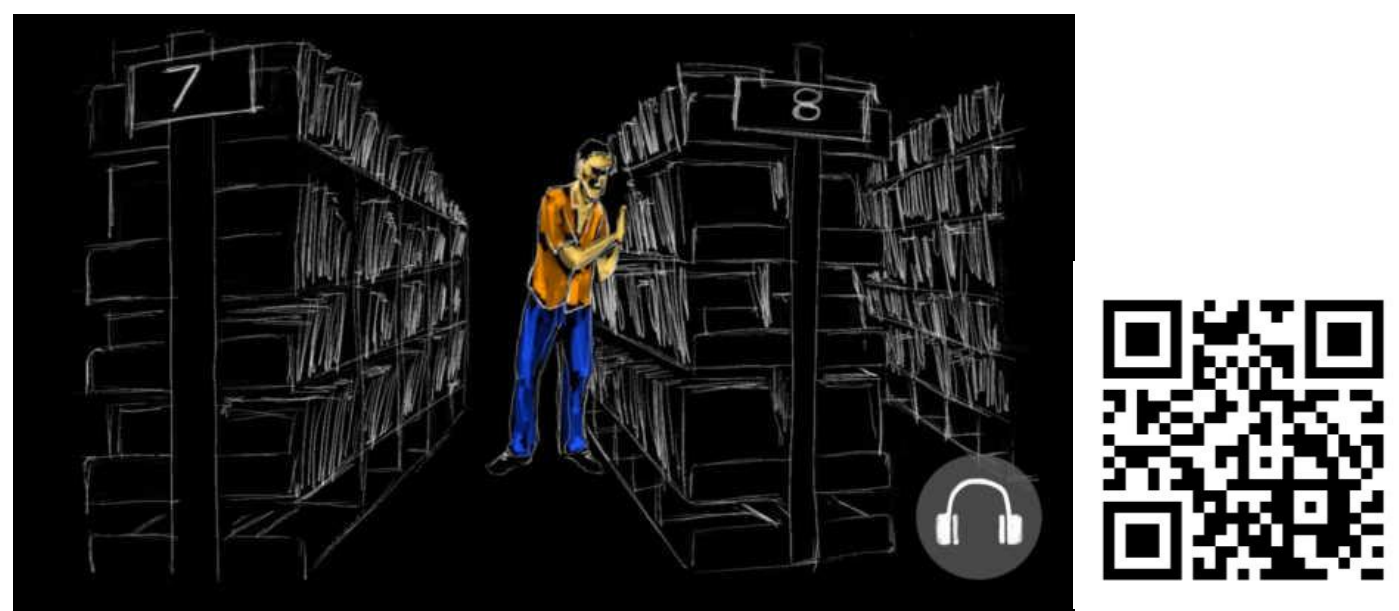

Figura 44: Grafite digital, O Enigma de Voynich, por Achiles Luciano, 2017. Fonte:

https://catracalivre.com.br/sp/spetaculo/gratis/excompanhia-de-teatro-lanca-drama-em-audio-3d-e-grafite-digital/ No QR code ao lado é possível assistir a um tutorial do aplicativo.

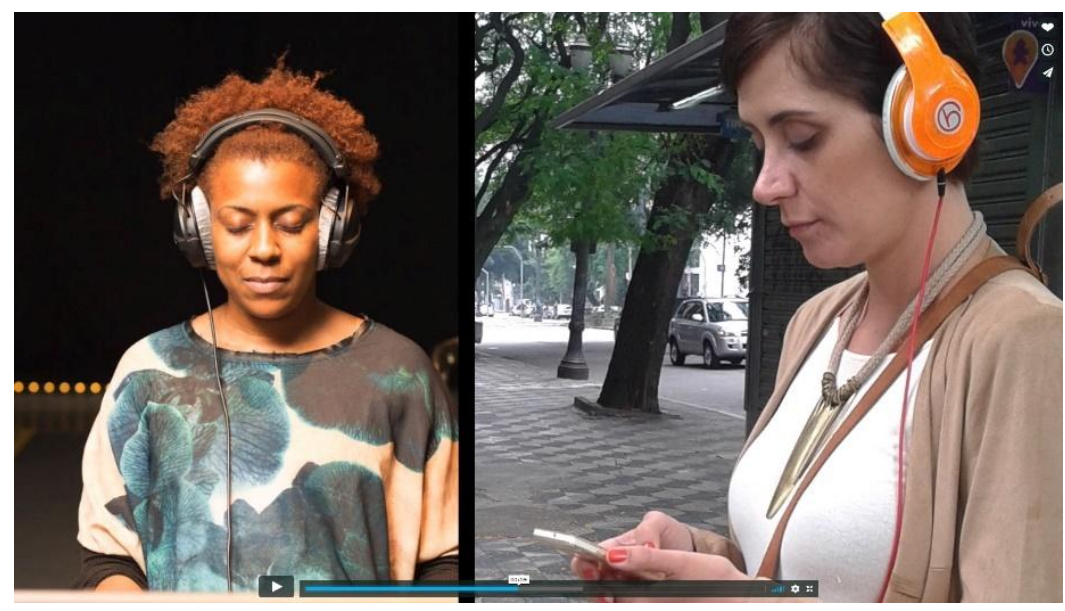

Figura 45: Imagem ilustrativa do uso do aplicativo em seu vídeo de divulgação disponível em http://www.excompanhiadeteatro.com.br/voynich. Acesso 16/12/2017

A narrativa conta com cenas de ação, suspense, sexo e ocorre ao longo de 32 anos da vida do personagem (1983-2015), passando por momentos históricos brasileiros como as "Diretas Já" (1984) e o "Massacre do Carandiru" (1992). Durante esse período, José percebe que na tentativa de decodificar o manuscrito, começa a perder a memória.

\footnotetext{
${ }^{108}$ Manuscrito ilustrado escrito há 600 anos, com um sistema de escrita nunca decifrado.
} 
No transcorrer da história, determinadas cenas só podem ser acessadas em locais pré-definidos (como as bibliotecas Mário de Andrade e Sérgio Miliet, no CCSP); portanto, é necessário o deslocamento físico ao local (o aplicativo utiliza uma ferramenta de geolocalização).

De acordo com os autores, esse projeto propõe uma "discussão sobre a excessiva transferência da memória humana para o universo digital, a partir de um constante registro de experiências diárias em vídeos e fotos, diminuindo diretamente a vivência da própria experiência enquanto ela acontece"109. O inovador formato da obra dramatúrgica interativa interfere com a cognição, percepção e interpretação do audioespectador e desloca-o de sua zona de conforto para visitar outros locais da cidade de São Paulo. O aplicativo está disponível para download tanto para o sistema Android (Google Playstore) quanto IOS (Itunes).

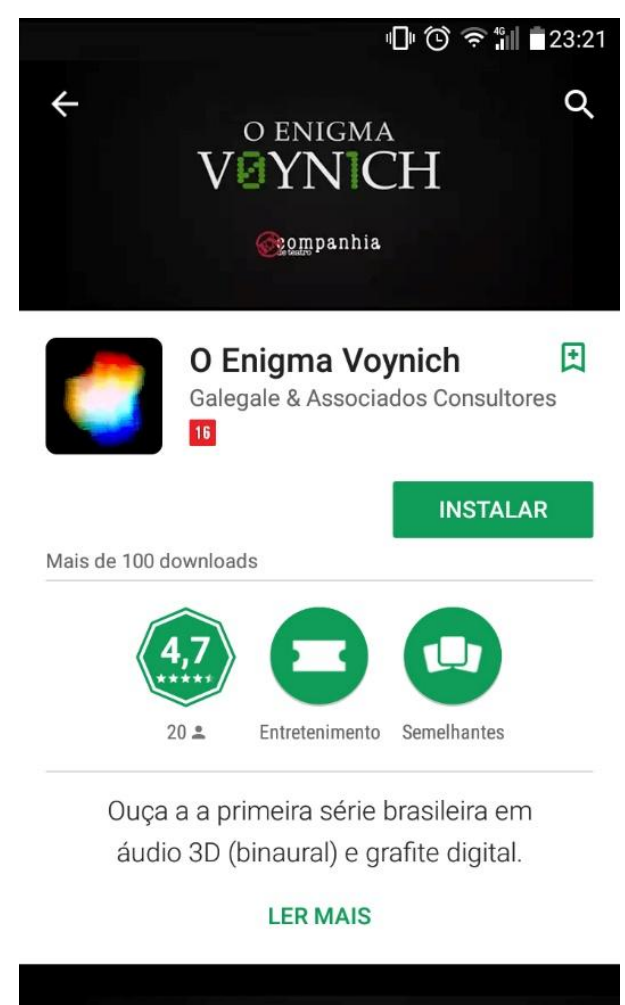

Figura 46: O Enigma de Voynich no Google Playstore, captura da tela diretamente do celular.

Nessa obra, o teatro volta a ser o centro de uma obra transmidiática. Os autores abrem mão do uso de um palco para envolver o público, combinando sons, texto e ilustração digital a serem apreciados através de um aplicativo para

\footnotetext{
${ }^{109}$ Segundo o próprio site do projeto em http://www.excompanhiadeteatro.com.br/voynich. Acesso em $12 / 12 / 2017$.
} 
dispositivos móveis. A cidade passa ser parte do objeto artístico a partir do momento em que a obra exige o deslocamento do espectador para locais específicos a fim de poder acompanhar a história. A transmídia, aqui, é aplicada pelo uso de múltiplas mídias, participação e, fundamentalmente, imersão.

\subsection{Martha Gabriel e transmídia artística}

A autora, pesquisadora e artista Martha Gabriel ${ }^{110}$ defendeu sua tese sobre arte transmidiática na era digital (ECA/USP), em 2012. No trabalho ela discorre criteriosamente sobre todas as tecnologias digitais disponíveis (em 2012, evidenciando dessa forma sua graduação em engenharia) que podem ser incorporadas em obras de arte e reflete sobre as possibilidades criativas. Para tanto, ela produziu uma série de quatro obras digitais transmidiáticas, duas delas, descritas a seguir.

\subsection{1 moZaico de voSes ${ }^{111}$}

De acordo com a autora, este é um trabalho reflexivo sobre o impacto tecnológico e sua convergência midiática no cotidiano humano. Trabalha com dualidades que não devem se contrapor, mas se hibridizar como simples/complexo, arte/ciência, individual/comunidade, passivo/ativo, entre outros.

\footnotetext{
${ }^{110}$ Martha Gabriel é uma das principais pesquisadoras digitais brasileiras, autora de vários livros sobre o assunto (Lançou "Eu você e os robôs" em 15/12/2017).

${ }_{11}$ Segundo o site da autora, obra MoZaico de voSes foi exibida nas seguintes manifestações: Exposições: 2004 - Sound Toys, UK; 2005 - spotlighted no Turbulence.org, New York US; 2005 - 150 Festival Internacional de Arte Eletrônica Videobrasil, Brasil; 2005 - menção honrosa no prog:ME, Brasil; 2005 - Ingenio 400 - Fourth Centennial of Don Quixote, Espanha; 2005 - FILE Festival, Brasil; 2005 - Museu do Essencial e do Além Disso, Brasil; 2006 - FILE Festival Rio, Brasil; 2006 - special mention no II Media Arts - Festival de La Imagen Unesco, Colombia; 2006 - Mostra Conexões Tecnológicas - Prêmio Sergio Motta, Brasil; 2006 - Consciousness Reframed 8, Plymouth, UK (paper); 2006 - SIGGRAPH Art Gallery, Boston, US; 2006 - Upgrade!Boston, Boston, US (paper); 2006 - res-Qualia; 2006 - premiado no Fiat Mostra Brasil; 2006 - instalação convidada em destaque na Mostra SESC Rio de Arte Eletrônica, Rio de Janeiro, Brasil; 2007 - integra a ArtBase do Rhizome.org at the Museum of Contemporary Art, New York, US; 2007 - espaceSONO at SAT Gallery, Montreal, CA, Sept; 2008 - Visionary Landscapes Exhibition na ELO Conference, Portland, US; 2009 Joburg Art Fair, Johannesburg, África do Sul.
} 
A obra cria um mosaico colorido visual e sonoro, combinando a internet e o telefone. Pessoas de qualquer parte do globo fazem uma ligação, escolhem uma cor e em seguida verbalizam uma frase que será gravada e repetida cada vez que seu mosaico for clicado. A obra pode ser vista tanto na web, como em projeção (como foi feito em exposições).

A participação do público torna o resultado final do mosaico imprevisível, a gravação de vozes em diversas línguas gera, segundo a autora, "uma comunidade visual/sonora onde cada pastilha com as informações individuais das pessoas participantes (cor e gravação de voz) formam e participam do todo, criando um diálogo comunidade/individual" ${ }^{\prime 12}$.
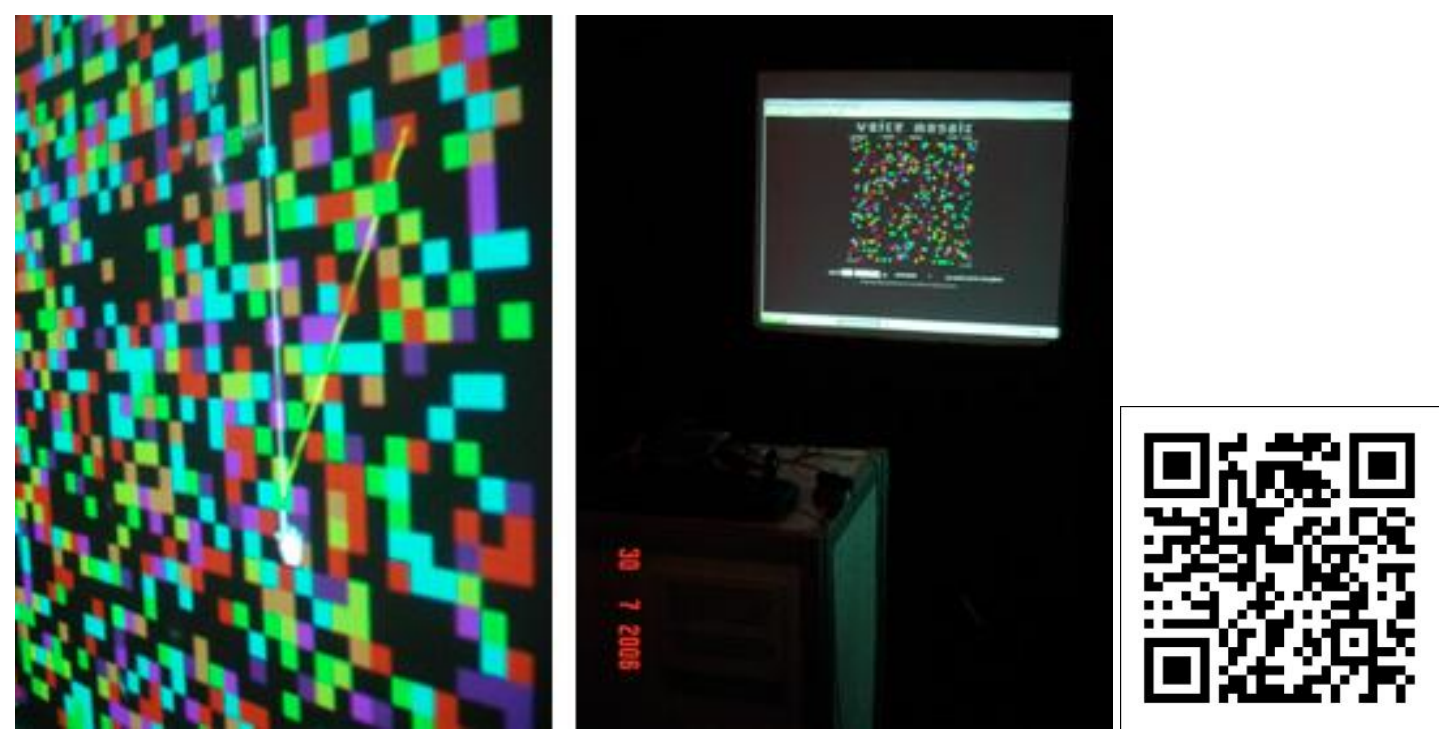

Figura 47: moZaico de voSes, de Martha Gabriel. À direita, projeção do moZaico de voSes em tela e instalação do trabalho no SIGGRAPH 2006. Através do QR code ao lado, é possível ver um exemplo da obra em funcionamento. Fonte: http://www.martha.com.br/mozaico-de-voses/. Acesso 14/12/2017

Atualmente a obra contém mais de 800 pastilhas, e foi vendida ao Sr. Pedro Barbosa em 2007 (coleção particular). É transmidiática por ser participativa, combinar múltiplos meios midiáticos e sons.

\footnotetext{
${ }^{112}$ Segundo descrição no seu site: http://www.martha.com.br/mozaico-de-voses/. Acesso em 14/12/2017
} 


\subsubsection{Sensitive Rose ${ }^{113}$}

Exposto pela primeira vez na exposição Nokia Trends São Paulo em 2008, Sensitive Rose tem o formato de uma rosa dos ventos feita de QRcodes, cujo norte é apontado pelo desejo das pessoas. É apresentado em uma grande projeção (3×3m) e, através de dispositivos móveis, o observador escaneia a Tag (QRcode) de entrada da projeção, em seguida recebe a pergunta (no celular): "O que você quer da vida?". As respostas são mapeadas e compõe as mudanças da imagem. De acordo com a autora:

Do mesmo modo que a Poesia Concreta usava códigos alfabéticos - letras e palavras - utilizando suas características visuais para criar significado, o SENSITIVE ROSE tem o mesmo objetivo: criar uma poesia concreta interativa, formada de mobile tags (códigos visuais de informação) de um modo que a entrada e saída de dados seja feita completamente por meio do trabalho (na projeção). ${ }^{114}$

\footnotetext{
${ }^{113}$ Segundo site da autora, obra MoZaico de voSes foi exibida nas seguintes manifestações: Exposições: 2008 - Nokia Trends São Paulo;2009 - spotlighted pelo Turbulence.org, New York, US; 2009 - V Media Arts Festival de La Imagen, Colombia; 2009 - e-Poetry, Barcelona; 2009 - ISEA International Symposium on Electronic Arts, Belfest (artistic presentation, agosto/2009); 2009 - convidado para mostra solo no SESC Araraquara, Brazil (Nov e Dez/2009); 2009 - Florence Biennale, Florença (dez/2009) - premiado na categoria vídeo; 2010 - Technarte, Bilbao, Espanha - convidado para a exposição de new media arte (apr/2010); 2010 Editora Abril, São Paulo - trabalho participante da mostra solo no prédio da editora em São Paulo, durante a Semana Digital (set/2010); 2010 - Galeria Olido, São Paulo - trabalho participante da mostra solo LIFE ON LINE OF LINE, durante o evento Outubro Independente 2010 (out/2010); 2011 - ISEA 2011, Istambul,Turquia; 2012 Art in Focus: Modern Masters, New York, USA - convidado (jan/2012); 2012 -Virada Digital, Paraty, RJ mai/2012; 2012 - Hartman Event, Ultrecht, Holanda - out/2012.
}

${ }^{114}$ Descritivo da obra no site de Martha Gabriel em http://www.martha.com.br/sensitive-rose/ 

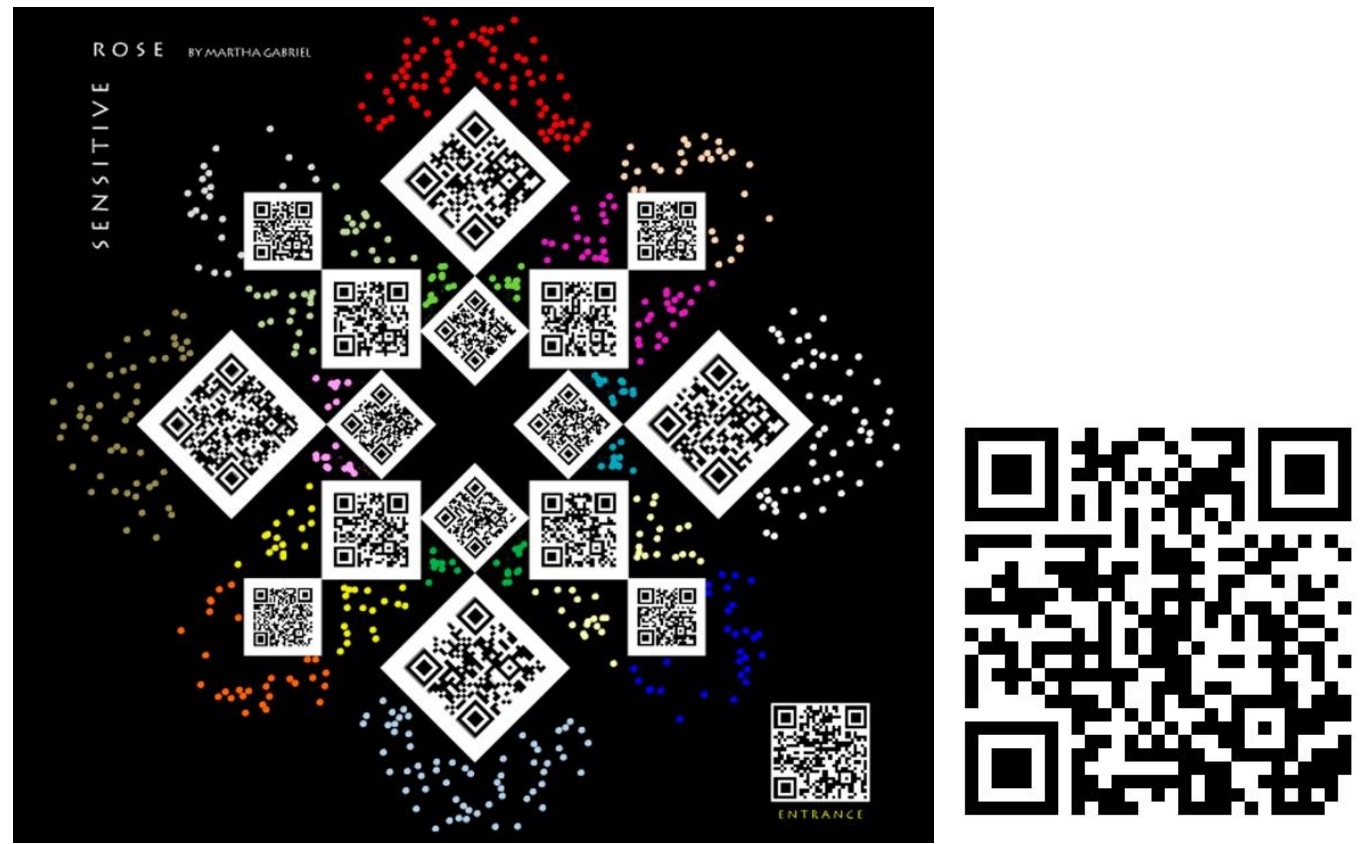

Figura 48: Sensitive Rose de Martha Gabriel. Ao lado, o QR Code leva a um vídeo demonstrativo da obra.

A navegação, através dessa rosa dos ventos digital, é feita através da web, com sua poética decodificada por móbile tags (QR Codes). As respostas aparecem na imagem na forma das bolinhas coloridas e se acumulam de acordo com o volume de respostas semelhantes. Essa obra transmidiática é composta de mútiplas tecnologias midiáticas e é interativa.

\subsection{Fragmentos}

Idealizada a partir de uma série de poemas criados (desde 2009) pelo autor Luís R. Lopreto (performer, ator, artista plástico, professor), Fragmentos é uma obra transmídia que une poesia, música, dança, pintura com luz, teatro, fotografia e vídeo. Criada para ser realizada sempre à noite, a obra já foi apresentada em diversos espaços desde $2011^{115}$.

\footnotetext{
${ }^{115}$ Como no MIS (2012), I Mostra de Arte no NEXT - Núcleo Experimental de Arte - São Paulo (2012) e o Festival de Inverno de Paranapiacaba de 2011 a 2014.
} 


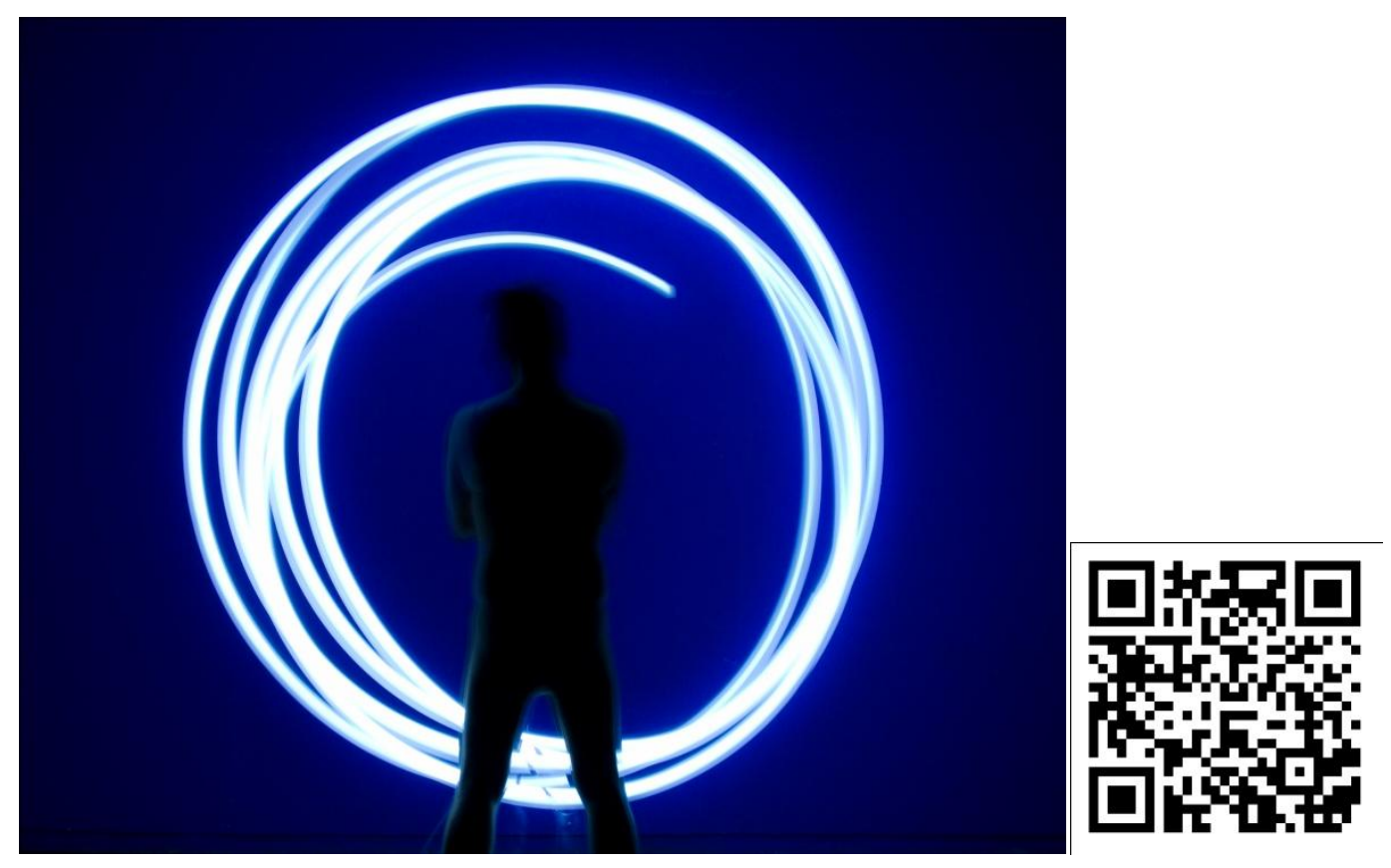

Figura 49: Registro fotográfico da apresentação de Fragmentos. Na imagem, Lopreto faz lightpainting. No QR code ao lado, é possível assistir a um trecho da performance no Youtube. Fonte:

http://www.cursodehistoriadaarte.com.br/lopreto/index.php/page/2/

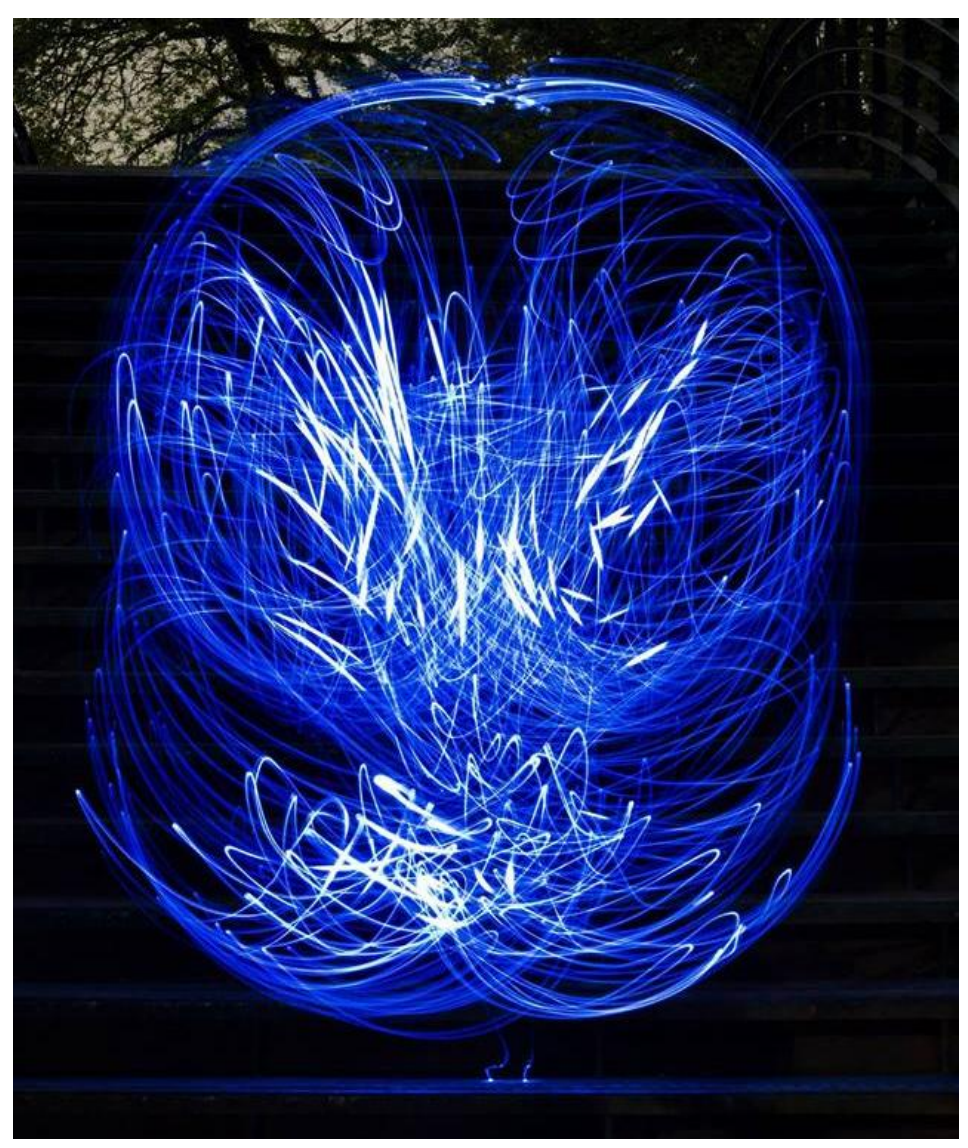

Figura 50: Fragmentos - Ensaio III - Solo performer Lopreto - Foto Felipe Costa - Ibirapuera São Paulo. Fonte: Imagens cedidas por Lopreto. 


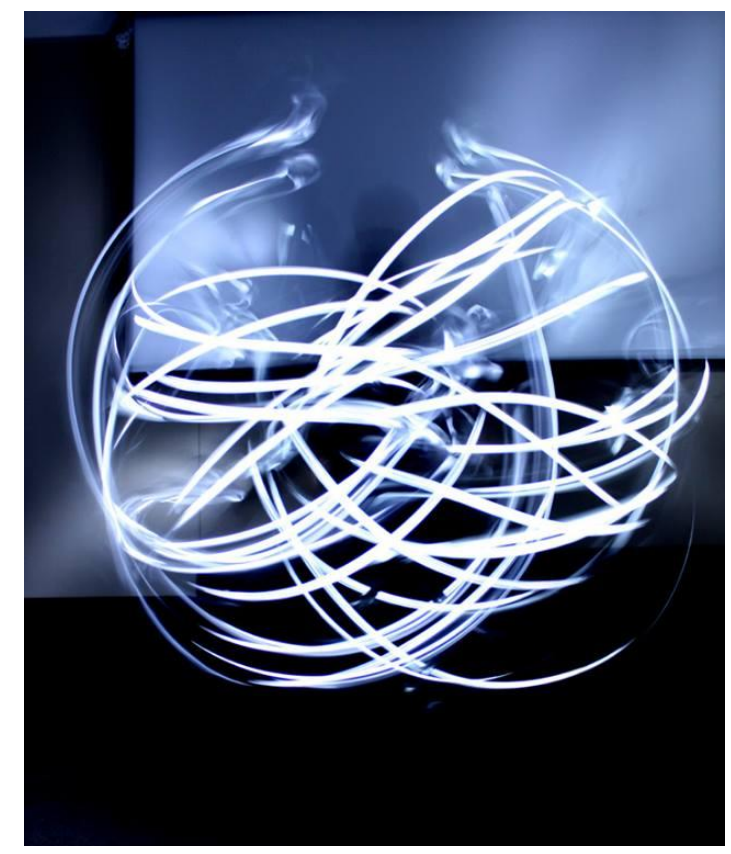

Figura 51: fragmentos - Ensaio XVI, solo performer Lopreto, intérprete dos poemas Osmar Amorim, música Daniel Muray, fotografia Fabiana Stig - MIS (Museu da Imagem e do Som São Paulo 2012. Fonte: Fotos cedidas por Lopreto.

Durante o espetáculo, atores recitam os poemas acompanhados por músicos que criaram partituras específicas para a obra. Lopreto inicia sua performance dançando conforme os ritmos, tendo seu ápice na light painting que é acompanhada por fotógrafos e vídeomakers. O espetáculo tem cerca de uma hora ininterrupta. Esta obra é transmidiática por combinar coautoria, performance, música, poesia, fotografia e vídeo.

"Fragmentos" conta com a colaboração de Daniel Muray (violão acústico e computadores); Celina Charlier (flauta transversal); Giulliano Spitalletti (bateria, percussão em metal); Flávia Lobatti e Osmar Amorim (atores); Felipe Costa, Alécio Cesar, Ricardo Kraftmam e Fabiana Stig (fotografia); Felipe Costa, Thiago Barbosa e Ricardo Kraftmam (Videomakers). 


\section{Conclusão}

Esta pesquisa seguiu uma linha de raciocínio histórico para definir o conceito de transmídia artística. No capítulo um, foi descrita a evolução tecnológica computacional, que proporcionou bases da arte digital, e o processo de sua popularização. Também foi abordado o surgimento da internet, sua evolução, sua gradual inserção no cotidiano, sua expansão no mundo todo, sua influência na circulação do conhecimento e nas conexões interpessoais.

Tais conexões modificaram-se a partir das redes sociais - que por um lado aproximam (no sentido de poder falar com pessoas de lugares distantes ou até mesmo reencontrar pessoas do passado, com que se havia perdido contato) e por outro lado, distanciam (quando as pessoas optam por se comunicar apenas por esses meios ao invés de se encontrarem pessoalmente). Criou-se um espaço de exposição pessoal, onde o público compartilha imagens, vídeos e informações particulares, muitas vezes sem se preocupar com as consequências da visibilidade de sua intimidade. Na perspectiva da transmídia digital, as redes sociais abrem um ambiente interativo entre artista, obra e público.

As redes sociais ainda criam um espaço de informação mediada; algoritmos são programados para exibir apenas o que for do agrado ou do interesse pessoal de cada um. Esta seleção é feita a partir das escolhas do indivíduo (curtidas, compartilhamentos, comentários).

Ainda no mesmo capítulo os conceitos de multimídia, crossmídia, intermídia, transmídia e hipermídia foram definidos e discutidos. A partir dessa base terminológica e teórica foi possível separar a transmídia de multimídia, por exemplo, e compreender que crossmídia foi um passo para a criação da transmídia no marketing - assim como a intermídia e a multimídia foram para a transmídia artística. Dentro deste universo, o homem passou a ser cíbrido, conceito que fundamenta a ideia de um ser duplicado nas dimensões virtuais e físicas. Ao utilizar a tecnologia como uma extensão do próprio corpo, experimenta outras dimensões de si mesmo, projetadas no virtual, e também habita um tempo de transformação tecnológica iminente, no qual o futuro parece se aproximar vertiginosamente, ao menos, e 
especialmente, no universo mercadológico dos novos gadgets eletrônicos. (Anders, 2001)

Além disso, um fluxo constante de informação tornou-se parte do cotidiano em quantidades muito maiores do que o cérebro tem capacidade de armazenar e compreender.

O segundo capítulo se dedica a traçar uma breve retrospectiva do relacionamento entre arte e tecnologia; demonstra a resistência ou mesmo o preconceito que por vezes contamina a gradual introdução de uma nova manifestação artística e o esforço para superar essa intolerância (como ocorreu com a fotografia no século XIX, em que o movimento pictorialista foi idealizado para aproximar as artes plásticas à fotografia).

O desenvolvimento científico e industrial que se acelerou sobremaneira no início do século XX (com a chegada da produção em massa de objetos de consumo, a eclosão das comunicações de massa e incorporações tecnológicas como a TV e o cinema) abriu caminho para manifestações artísticas cada vez mais inovadoras, movimentos de vanguarda, que desencadearam os ready-mades de Duchamp, a reprodutibilidade de Andy Warhol, a arte conceitual, para citar apenas algumas das revoluções artísticas que surgiram.

A arte digital surge quase que consecutivamente ao computador, mas foi necessário tempo e o advento da internet para que ela fosse aceita, tivesse grande circulação, e realmente se tornar parte do cenário artístico internacional, do portfólio dos artistas e matéria de reflexão de críticos e historiadores.

O capítulo também discorre sobre arte participativa e imersão, conceitos que estão longe de serem características contemporâneas, pois podem ser apontados em diversos momentos da história da arte.

Essa combinação de fatores industriais, mercadológicos, midiáticos e artísticos possibilitaram, posteriormente, o surgimento da transmídia artística digital, como um fenômeno típico de convergência.

A partir deste embasamento conceitual histórico, o terceiro capítulo discorre sobre arte transmidiática e a arte transmidiada, estabelecendo uma diferença nítida 
entre estas duas formas inéditas no contexto artístico e típicas do início do século $\mathrm{XXI}$.

Enquanto a arte transmídia passou a ser reconhecida, a arte transmidiada muitas vezes não é percebida, já que é feita por diversos autores, cujas obras também são separadas por intervalos de tempo variados. Essa alienação também pode ocorrer pelo excesso de informação que atinge o público diariamente, desconhecimento a respeito da história da arte ou até pela notícia mediada pelas redes sociais.

Como afirmado anteriormente, qualquer obra pode ser transmidiada, dando continuidade à criação, ampliando o universo da obra.

Nos casos das obras de Vermeer e Van Gogh, os autores jamais poderiam imaginar que uma pintura poderia transcender para outras narrativas e mídias; porém, a artista Mieko Shiomi teve a oportunidade de ver sua obra se expandir e migrar para outros meios - fato que trouxe à compositora satisfação e expectativa, à medida que aguarda que outros artistas se apropriem e ressignifiquem seu trabalho.

Entretanto, o foco principal deste trabalho são as obras que foram concebidas com o intuito de serem transmidiáticas. Para dar apoio às análises, as entrevistas com alguns dos artistas criadores das obras apresentadas enriqueceu a compreensão de suas criações, elucidando a perspectiva pessoal de cada um sobre sua obra. Todos os entrevistados se autointitulam artistas transmidiáticos, e procuram sempre pesquisar novas tecnologias para enriquecer as possibilidades criativas de suas obras.

Para o grupo ExCompanhia de Teatro, a transmídia surgiu por acaso enquanto seus integrantes tentavam criar uma obra de dramaturgia que fugisse do convencional, que fosse participativa e incentivasse o público a acompanhar a história $^{116}$

Na obra "Eu Negociando Sentidos", as redes sociais são o estopim inicial da narrativa, quando as personagens se apresentam e falam de suas intimidades com completos estranhos (o público da peça). Por mais absurdo que isso possa parecer,

\footnotetext{
${ }^{116}$ Segundo afirma em entrevista cedida à Luciana Allegretti no dia 28/07/2016. Entrevista completa nos anexos.
} 
essa forma de relacionamento é comum atualmente, e é recebida pelo espectador com naturalidade. A internet é, portanto, essencial no primeiro ato da obra, cujas imagens e textos são compartilhados e comentados. Os atores incorporam as personagens sem um roteiro pronto referente ao falar; devem reagir de acordo com o histórico e a psique criada pelos autores.

O público cria uma relação afetiva e íntima com a história a partir dessa interação entre público e personagem, e cada vez mais, sente-se incentivado a segui-la para poder presenciar o ato final, que ocorre pessoalmente em uma festa sediada pelo grupo de teatro. O espectador fica completamente envolvido, e, às vezes, perde a noção entre realidade e ficção ${ }^{117}$.

Em "Enigma de Voynich" a dramaturgia é abordada de outra forma. O espectador se isola, observando as imagens apresentadas e ouvindo a narrativa pelo aplicativo em seu celular (que é feita de modo a imitar o som real, simulando a sensação de estar presente na história). Nesse caso, o objetivo é personificar o protagonista e acompanhá-lo, tendo por vezes que se deslocar pela cidade para dar continuidade à ação.

Tanto em "Eu Negociando Sentidos" quanto em "O Enigma Voynich", a transmídia é ferramenta para evidenciar a questão que a própria transmídia carrega em si: o excesso, a exposição e a virtualização do homem.

Também de forma crítica se comporta o grupo Etecétera, em sua obra "Errar de Dios" que aplica a transmídia para inserir o observador dentro de sua narrativa questionadora da religião católica e seus dogmas. A imersão dentro do universo conceitual da obra é feita na sala do fundo, onde o observador fica isolado do resto da exposição e é convidado pelos autores a refletir sobre os conflitos, corrupção e a ganância da religião cristã. Porém também critica o homem, que mergulha em ideologias e tiraniza seus iguais e, agindo como Deus, constrói e destrói.

Em "moZaico de voSes", a artista Martha Gabriel pondera sobre o ser humano envolto por múltiplas tecnologias midiáticas e sua posição dentro da nova esfera sociotecnológica. A voz é convertida em imagem e compõe um mosaico colorido que se modifica com a participação do público. Dessa forma, cada 
participante torna-se parte da obra a partir da gravação de sua voz e da escolha de uma cor, como se um pedaço de cada pessoa compusesse esse espaço cibernético.

Em "Sensitive Rose", da mesma autora, sentimentos são codificados em QR Codes, que só podem ser lidos a partir de aplicativos em dispositivos móveis. A partir das escolhas do público, a rosa dos ventos composta pelos QR Codes se modifica e ao norte fica o sentimento mais citado pelos participantes. Neste trabalho, sentimentos são digitalizados e tornam-se incompreensíveis a olho nu. Martha Gabriel apresenta, portanto, uma postura reflexiva em suas obras, estudando o impacto das novas tecnologias no cotidiano da sociedade.

As duas obras inserem o ser humano no computador, seja através da voz ou sentimentos: parte do ser de cada participante se separa do referente e torna-se parte da máquina. Interpretando por este prisma, um sentimento duplo é incentivado pela artista: o horror de perder parte da humanidade, tornando-se máquina, e a sugestão de eternidade, tendo uma parte de si transportada para o mundo virtual.

Por outro lado, Pedro Paulo Rocha propõe que a transmídia seja um fator facilitador da criação, gerando possibilidades de coautoria, viralização da arte e reinterpretação. O artista, de forma muito mais caótica que os outros analisados, abraça a tecnologia com voracidade. Suas obras reportam sua postura ativista e contestadora dos cânones clássicos da arte, procurando sempre estar fora do circuito tradicional artístico.

Para ele, a internet abre uma porta de circulação artística ilimitada, com infinitas janelas que dão acesso a múltiplos participantes e observadores. Uma obra pode ser perpetuamente aberta, modificando-se através da interferência de milhares de internautas.

Luis Lopreto também vê a construção narrativa por multimeios de forma positiva, e considera "transmídia" como um termo intimamente artístico: "Aprendi com o Mestre Willys de Castro ${ }^{118}$ a definição 'Arte Constelar - a maneira de uma constelação e suas interações' -, para o que chamamos transmídia ou transdisciplina"119. Sua obra, "Fragmentos", já foi criada com a proposta

\footnotetext{
${ }^{118}$ Willys de Castro (1926-1988): Cenógrafo, artista gráfico, figurinista, pintor e desenhista.

${ }^{119}$ Entrevista com Luis R. Lopreto, realizar por e-mail em 17/12/2017.
} 
transmidiática, e sua poesia é fio condutor que une todas as outras expressões, música, dança e imagem.

A participação do público não é prioridade na obra de Lopreto, mas sim a experiência. Apesar de sua obra ser transmidiática, o objetivo é puramente estético, embriagar o público com movimento, poesia e luzes. De fato, o autor não se afasta de suas origens na dramaturgia. Sua obra, sempre apresentada em campos abertos, ressignifica o teatro grego.

A partir destas análises, retomando a pergunta inicial deste estudo, conclui-se que a arte transmidiática ocorre tanto como consequência da necessidade contemporânea de interatividade tecnossocial quanto pela viabilidade ferramental disponível aos artistas, a partir da tecnologia digital. Muito mais do que o uso de um amplo espectro de ferramentas tecnológicas, tornam-se necessárias ao artista a interação, a multiplicação, a hibridação, a coautoria e a visualização, que os múltiplos suportes das atuais tecnologias proporcionam. Por outro lado, o público, cada vez mais conectado, procura pelas novas experiências que essas obras possam propiciar.

No entanto, o universo da arte transmidiática vai além das obras criadas com este objetivo. A acessibilidade das tecnologias permite a transmidiação de diversas obras não criadas para multimeios. A tecnologia de giga-pixels do Google, por exemplo, é capaz de destacar uma parte de um quadro que é invisível ao olho humano e outro artista pode, através dela, criar uma nova narrativa que expande a obra original. Imagens bidimensionais podem ser reinventadas como tridimensionais e o público pode literalmente andar dentro do quadro.

Depois de absorver, observar e experimentar as obras apresentadas, novas questões se apresentaram: será que o uso do termo transmídia, nascido da comunicação, é suficiente para descrever tais obras? Tendo em vista que nem toda obra artística tem necessariamente um conteúdo narrativo, ela pode ser considerada transmidiática por utilizar multimeios platafórmicos?

Percebe-se - como todos os processos aliados à tecnologia nas últimas décadas - que mesmo a acepção de transmídia, especialmente ligada à arte, gerou, ou talvez transformou, uma definição de conteúdo distinta das noções originais. 
A ideia de transmídia artística pressupõe o emprego de diversas ferramentas em sua criação - em relação à técnica, seu componente definidor não é o meio em que se elabora, mas sim o uso possível de qualquer recurso. Da mesma forma, as redes sociais permitem que criadores participem em conjunto de sua elaboração, em cocriação. Mais ainda, as tecnologias digitais e de telecomunicação consentem que o público participe, interaja e até modifique a composição diretamente.

Os dogmas que foram estabelecidos para a transmídia comercial não devem ser aplicados em uma perspectiva artística. Uma lista de regras a serem obedecidas é fator de controle e limitação. A transmídia artística é livre para se expressar por quantos meios forem necessários, é modificada e expandida a partir de interferência de novos autores e da criação de novas tecnologias. Envolve o público e incentiva a participação, é comentada, curtida e compartilhada nas redes sociais. Em suma, uma obra transmidiática tem começo e meio, mas pode não ter fim. 


\section{Referências Bibliográficas}

Agência IBGE Notícias. PNAD TIC: em 2014, pela primeira vez, celulares superaram microcomputadores no acesso domiciliar à Internet. Disponível em: https://agenciadenoticias.ibge.gov.br/9564-pnad-tic-em-2014-pela-primeira-vezcelulares-superaram-microcomputadores-no-acesso-domiciliar-a-internet.html. Acesso em 12/07/2017.

ALVARENGA, Lídia; SOUZA, Renato Rocha. A Web semântica e suas contribuições para a ciência da informação. Ci. Inf., Brasília, v. 33, n. 1, p. 132141, jan./abril 2004. Disponível em: http://www.scielo.br/scielo.php?pid=S010019652004000100016\&script=sci_abstract\&tIng=pt

ANDERS, Peter. Toward an architecture of mind. In: CAiiA-STAR SYMPOSIUM: 'Exttreme parameters. New dimensions of interactivity' (july. 2001). Disponível em: https://artnodes.uoc.edu/articles/abstract/10.7238/a.v0i1.675/. Acesso em 26/09/2017.

ARANTES, Priscila. Arte e mídia: perspectivas da estética digital. São Paulo: Senac, 2005. 224 p.

ARAÚJO, Yara Rondon Guasque. Telepresença: interação e interfaces. São Paulo: EDUC / Fapesp, 2005. 1982 p.

ARCHER, M. Arte contemporânea: uma história concisa. São Paulo: Martins Fontes, $2^{\mathrm{a}}$ ed. 2012. $320 \mathrm{p}$.

ARGAN, G. C. Arte moderna. Do iluminismo aos movimentos contemporâneos. São Paulo: Companhia das Letras, 1995. 736 p.

ARNAUT, Rodrigo Dias, etal. Era Transmídia. Revista Geminis ano 2, número 2. Pág. 259-275.

ARRUDA, Felipe. Áudio binaural: efeito 3D em fones de ouvido estéreo. Tecmundo, 2011. Disponível em https://www.tecmundo.com.br/fone-deouvido/11683-audio-binaural-efeito-3d-em-fones-de-ouvido-estereo.htm. Acesso em 12/12/2017. 
BAIRON, Sérgio; Petry, Luís Carlos. Hipermídia, psicanálise e história da cultura: making off. São Paulo: Editora Mackenzie, 2000. 147 p.

BARICHELLO, Eugenia Mariano; Carvalho, Luciana Menezes. Mídias sociais digitais a partir da ideia mcluhaniana de médium-ambiência. Matrizes. Ano 7 no 1 jan./jun. 2013. São Paulo. Brasil. p. 238-246.

BEIGUELMAN, Giselle. Admirável mundo cíbrido. In: Cultura em fluxo: novas mediações em rede. Págs. 264-282. Editora PUC Minas, 2004.

BENJAMIN, Walter. A Obra de arte na época de sua reprodutibilidade técnica. Porto Alegre: Editora Zouk, 2012. 127 p.

BERGER, Pierre. Immersion from Goggles to Transmedia. In: Laval Virtual - 16을 Rencontre Internationales des Technologies Etusages du Virtuel. Laval (France), 2014.

BERNARDO, Nuno. The Producers Guide to Transmedia.Lisboa: BeActive, 2011.

BOYD, Dannah; ITO, Mizuko; JENKINS, Henry. Participatory Culture in a Network Era.UK, Polity Press, 2016. Ebook.

BRIGGS, Asa; BURKE, Peter. Uma História Social da Mídia: De Gutenberg à Internet. Rio de Janeiro: Editora Jorge Zahar, 2004. 376 p.

CAMPALANS, Carolina. Narrativas transmedia. Entre teorías y prácticas. Editorial UOC, S.L , 2014. 241 p.

CANTON, Katia. Temas da Arte Contemporânea. São Paulo: Martins Fontes, 2009.

CAUQUELIN, Anne. Arte contemporânea: uma introdução. São Paulo: Martins Fontes, 2005. 111p.

CHUN, Wendy; RHODE, Lisa Marie. Working the Digital Humanities: Uncovering Shadows between the Dark and the Light. Volume 25, Number 1, 2014. Brown University and differences: A Journal of Feminist Cultural.

CONCEIÇÃO, Juara de Castro da; FERREIRA, Rosiete de Jesus. A Telenovela transborda: Narrativa ficcional e transmídia no contexto brasileiro. Artigo para 
INTERCON - Sociedade Brasileira de Estudos Interdisciplinares da Comunicação. Rio de Janeiro, 2015.

CORMODE, Grahan; KRISHNAMURTHY, Balachander. Key differences between Web 1.0 and Web 2.0. First Monday, Peer-Reviewed Journal on the Internet. Vol. 13, n. 6-2. Junho, 2008. Disponível em:

http://firstmonday.org/ojs/index.php/fm/article/view/2125/1972, acesso 12/01/2018.

CORRÊA, Elizabeth Saad. Centralidade, transversalidade e resiliência: reflexões sobre as três condições da contemporaneidade digital e a epistemologia da Comunicação. Trabalho apresentado na Divisão Temática Ibercom Epistemologia, Teoria e Metodologia da Comunicação no XIV Congresso Internacional IBERCOM, na Universidade de São Paulo, de 29 de março a 02 de abril de 2015.

Correio Brasiliense. Animação 'A paixão de Van Gogh' estreia nos cinemas europeus. Disponível em: http://www.correiobraziliense.com.br/app/noticia/diversaoe-arte/2017/10/19/interna diversao arte,634699/filme-animado-de-van-gogh.shtml. Acesso em 12/12/2017.

COUCHOT, Edmond. A tecnologia na arte: da fotografia à realidade virtual. Porto Alegre, UFRGS, 2003. 320 p.

COULDRY, Nick; JENKINS, Henry. Dialogues on the Participatory Promise of Contemporary Culture and Politics. International Journal of Communication 8 (2014), Forum 1107-1112.

DANTO, Arthur. Após o fim da arte. A arte contemporânea e os limites da história. São Paulo: Odysseus Editora, 2006. 294 p.

DELEUZE, Gilles. 0 que é 0 ato de Criação. Disponível em: < http://www.dailymotion.com/video/x1dlfsr_gilles-deleuze-o-que-e-o-ato-de-criacaolegendas-em-portugues_creation>. Acesso em: 28 dez. 2015.

DOMINGUES, Diana (Org.). A arte no século XXI : a humanização das tecnologias. São Paulo: Editora UNESP. 1997.

Arte, Ciência e Tecnologia: passado, presente e desafios. São Paulo: Editora UNESP, 2009. 570 p. 
Arte e vida no século XXI: a humanização das tecnologias. São Paulo: UNESP, 2003. 378 p.

DUBOIS. Phillippe. Cinema, Vídeo, Godard. São Paulo: Cosac Naify, 2014.

FERNANDES, Fábio. A construção do imaginário cyber. Willian Gibson, criador da cibercultura. São Paulo: Editora Anhembi Morumbi, 2006. 107 p.

FLUSSER,Vilém. Filosofia da caixa preta. Rio de Janeiro: Relume Dumará, 2002. $134 \mathrm{p}$.

FLATSCHART, Fábio. Web das coisas. São Paulo: Senac, 2016. Edição para Kindle.

FONSECA, Cléuzio F. História da computação: o caminho do pensamento e da tecnologia. EDIPUCRS, Porto Alegre,2007. 205 p.

FOWLE, Kate. Who Cares? Understanding the role of the curator today. In: KOURIS, Heather; RAND, Steven. Cautionary Tales: Critical Curating. $1^{\underline{a}}$ ed. Nova lorque, Apexart, 2007. p. 26-35.

FREIRE, Cristina. Arte conceitual. Rio de Janeiro: Jorge Zahar Ed., 2006. 81 p.

FUCHS, Christian; ET al. Theoretical Foundations of the Web: Cognition, Communication, and Co-Operation. Towards an Understanding of Web 1.0, 2.0, 3.0. Future Internet 2010, 2(1), 41-59. Disponível em: http://www.mdpi.com/19995903/2/1/41/htm. Acesso em 20/12/2017.

GABRIEL, Martha Carrer Cruz. Arte Transmídia na era digital. Tese Apresentada ao Programa de Pós-Graduação em Artes Visuais da Escola de Comunicação e Artes da Universidade de São Paulo. São Paulo, 2012. 219 p.

GANDELMAN, Henrique. De Gutenberg A Internet: Direitos Autorais na Era Digital. Rio de Janeiro: Record, 2001. 300 p.

GIANNETTI, Claudia. Ars telemática: telecomunicação, internet, ciberespaço. Coimbra: Relógio D’Água, 2011. 278 p. 
. Estética digital: sintopia da arte, a ciência e

a tecnologia. Belo Horizonte: C/Arte, 2006. 473 p.

GOSCIOLA, Vicente; CAMPALANS, Carolina; RENÓ, Denis. Narrativas Transmedia: Entre teorias y práticas. Bogotá: Universidad del Rosário, 2012.

GOSCIOLA, Vicente. Roteiro para as novas mídias - do game à TV interativa. Senac: São Paulo, 2003. 271 p.

GRAU, Oliver. Arte virtual: da ilusão à imersão. São Paulo: Editora SENAC São Paulo, 2007. 473 p.

GREENWOOD, Jeremy. The Third Industrial Revolution: Technology, Productivity and Income Inequality. Washington DC., The AEI Press, 1997. 100p.

HACKING, Juliet (org.). Tudo sobre fotografia. Rio de Janeiro: Sextante, 2012. 576 p.

HAYES, Gary. How to write a Transmedia Production Bible. Melbourne: Screen Australia, 2009. 182 p.

HIGGINS, Dick. Intermedia. Leonardo, Vol. 34, No. 1, pp. 49-54, 2001. Disponível em: https://muse.jhu.edu/article/19618/pdf.

HOQUET, Benjamin. La narration réinventée: Le guide de la création interactive et transmedia. CreateSpace Independent Publishing Platform, 2015. 442 p.

JENKINS, Henry. Cultura de Convergência.Editora Aleph, 2009.432 p.

Rethinking Media Change: The Aesthetics of Transition (Media in Transition). The MIT Press, 2004. 416 p.

Spreadable Media: Creating Value and Meaning in a Networked Culture (Postmillennial Pop). NYU Press, 2013. 352 p.

Transmedia Storytelling 101. Março, 2007. http://henryjenkins.org/2007/03/transmedia storytelling 101.html, acesso dia $20 / 11 / 2014$. 
Transmedia 202: Further Reflexions. 2011. Disponível em http://henryjenkins.org/2011/08/defining transmedia further re.html Acesso $31 / 05 / 2016$.

JOHNSON, Steven. Cultura da interface: como o computador transforma nossa maneira de criar e comunicar. Rio de Janeiro. Editora Jorge Zahar, 2001. 196 p.

KEMP, Simon. Digital in 2017 global overview. 2017, 107 slides. Disponível em: https://www.slideshare.net/wearesocialsg/digital-in-2017-global-

overview?from action=save. Acesso em: 10/12/2017.

KIDD, Jenny. Museums in the New Mediascape: Transmedia, Participation, Ethics. Ashgate Pub Co, 2014. 166 p.

KINDER, Marsha; MCPHERSON, Tara (Org.). Transmedia Frictions: The Digital, the Arts, and the Humanities. Univesity of California Press. 416 p.

Kynemas Fluxuz filmes, o projeto. Disponível em https://kynemasfluxuz.wordpress.com/sobre/. Acesso em 12/12/2017.

LEÃO, Lucia. O labirinto da hipermídia: Arquitetura e navegação no ciberespaço. São Paulo: Iluminuras, 1999. 160 p.

LÉVY, Pierre. Cibercultura. São Paulo: Editora 34, 2000. 264 p.

. As tecnologias da inteligência. São Paulo: Editora 34, 1995. 208 p.

LIESER, Wolf. Arte Digital. Coleção Art Pocket. H.F. Ullmann, 2009. 287 p.

LIEVROUW, Leah A. Materiality and media in communication and technologies studies: an unfinished project. In: Media technologies: essays on communications, materiality and society. Massachusetts: MIP Press, 2014.

LIMA, Juliana Domingos de. Artista transmídia defende quebra de paradigma para aliar crítica e cultura digital. São Paulo. Arte e Cultura - Instituto de Estudos Avançados, Ano 46, Ed. 62, 2013. Disponível em http://www.usp.br/aun/exibir?id=5396 - Acesso em 14/07/2016.

MACHADO, Arlindo. Arte e mídia. Rio de Janeiro: Jorge Zahar, 2007. 84 p. 
. Máquina e imaginário: o desafio das poéticas tecnológicas.

São Paulo: Edusp, 1993. 313 p.

MACHADO, Irene. Variáveis semióticas do espaço na cultura de meios. Galáxia (São Paulo, Online), n. 29, p. 70-82, jun. 2015. Disponível em: http://www.scielo.br/pdf/gal/n29/1982-2553-gal-29-0070.pdf

MANOVICH, Lev. Post Media Aesthetics. 2001. Disponível em http://manovich.net/index.php/projects/post-media-aesthetics

Cultural Data. Possibilities and limitations of the digital data universe. In Oliver Grau, ed., with Wendy Coones and Viola Rühse, Museum and Archive on the Move. Changing Cultural Institutions in the Digital Era. Berlin, Boston: De Gruyter, 2017. P. 259-276.

MARQUES, Pablo. Governo lançará Plano Nacional da Internet das Coisas no 2o semestre - Tecnologia pode movimentar US\$11 trilhões no mundo até 2025.

Poder 360, 2017. Disponível em: https://www.poder360.com.br/governo/governolancara-plano-nacional-de-internet-das-coisas-no-2o-semestre/. Acesso: 10/12/2017.

MICHELSON, James D. Cross Media marketing 101. Schooner Press, EUA, 2011. $138 \mathrm{p}$.

MATUCK, Arthur. O potencial dialógico da televisão - comunicação e arte na perspectiva do receptor. Annablume, São Paulo, 2009. 305 p.

MIEKO, Shiomi. Intermedia/Transmedia. 2013. Artigo disponível em : http://post.at.moma.org/content items/241-intermedia-transmedia Acesso 31/05/2016.

MCLUHAN, Marshall. Os meios de comunicação como extensões do homem. São Paulo: Cultrix, 2007. 407 p.

NUNES, Fábio Oliveira. Ctrl + alt + del: distúrbios em arte e tecnologia. São Paulo: Perspectiva, 2010. 315 p.

OLIVEIRA. Rodolfo. Caminhos Transmídia: Novas formas de comunicação e engajamento. São Paulo, Corazonada Brand Storytelling, 2014. 
PAIVA, Anderson dos Santos; PAIM, José Fernão Bastos. Arte, Transmídia e Realidade Aumentada. Artigo para JIG - I Jornada Internacional Gemnis: Entretenimento Transmídia, 2014.

PARENTE, André (org.).Imagem máquina: a era das tecnologias do virtual. Rio de Janeiro: Editora 34, 1993. 304 p.

PAUL, Cristiane. Digital Art. London: Thames \& Hudson; Third edition edition,2015. $272 \mathrm{p}$.

PERLIN, Ruth R. Media, Art Museums and Distant Audiences. In: MINTZ, Ann; THOMAS, Selma. The Virtual and the Real: Media in the Museum. $2^{\mathrm{a}}$ ed. Washington DC. American Association of Museums, 2000. p. 73-88.

PICCARD, Robert G. The humanisation of media? Social media and the reformation of communication. Disponivel em http://www.tandfonline.com/loi/rcrp20

PLAZA, Julio. Tradução intersemiótica. São Paulo: Perspectiva, 2003. 217 p.

PLAZA, Julio; TAVARES, Mônica. Processos criativos com os meios eletrônicos - poéticas digitais. São Paulo: Hucitec, 1998. 248 p.

PRADO, Gilberto. Arte Telemática: dos intercâmbios pontuais aos ambientes virtuais multiusuário. São Paulo: Itaú Cultural, 2003. 128 p.

PRATTEN, Robert. Getting Started in Transmedia Storytelling, a pratical guide for beginners. Amazon Publishing, 2011. $106 \mathrm{p}$.

PECK Pinheiro, Patrícia. Direito Digital. São Paulo: Saraiva, 2009.

PHILLIPS, Andrea. A Creator's Guide to Transmedia Storytelling: How to Captivate and Engage Audiences Across Multiple Platforms. McGraw-Hill Education; 1 edition (June 21, 2012). 288p.

POPPER, Frank. Art of the Electronic Age. London: Thames \& Hudson, 1997. Imago, 1992. 
RAMOS, Matheus Manzini. Fotografia e arte: demarcando fronteiras. Revista Contemporânea, Rio de Janeiro, no 12 p.129-142, 2009.

RIFKIN, Jeremy. The Third Industrial Revolution. How lateral power is transforming energy, the economy and the world. New York, Palgrave Macmillan, 2011. 304 p.

The Zero Marginal Cost Society: The Internet of Things, the Collaborative Commons, and the Eclipse of Capitalism. New York, Palgrave Macmillan, 2014. 290 p.

ROSE, Frank. The Art of Immersion. W. W. Norton \& Company. 2012. 384 p.

RUSH, Michael. Novas mídias na arte contemporânea. São Paulo: Martins fontes, 2006. 225 p.

RUTLEDGE, Pamela. Transmedia Storytelling - Integrated Marketing Form. 2013, 55 slides. Disponível em: https://pt.slideshare.net/pamelarutledge/transmediastorytelling-as-a-content-marketing-strategy/27. Acesso em: 20/12/2017.

SANTAELLA, Lucia. Culturas e artes do pós-humano - da cultura das mídias à cibercultura. Col. Comunicação. São Paulo: Paulus, 2010. 360 p.

. Por que as comunicações e as artes estão convergindo? São Paulo: Paulus Editora, 2005. 70 p.

SCOLARI, Carlo A. Transmedia Storytelling: New ways of communicating in the digital age. AC/E Digital Culture Annual Report, 2014. P. 69-79.

As Narrativas Transmídias, 1 ed. Barcelona: Editora Planeta,

2013. Ebook.

SANTOS, Manuella. Direito Autoral na Era Digital. Impactos, Controvérsias e Possíveis Soluções. São Paulo: Saraiva, 2009. 182 p.

SBRILLI, Antonella. Computerization, Digitalization and the Internet. In:

RAMPLEY, Matthew. et al. Art, History and Visual Studies in Europe: Transitional Discourses and National Frameworks. Brill's studies on art, art history, and intellectual history v. 4, The Netherlands, Brill, 2012. p. 135-149. 
SEVERINO, A. J. Metodologia do trabalho científico. São Paulo: Cortez, 2007, $535 \mathrm{p}$.

THOMAS, Selma. Mediated Realities: A Media Perspective. In: MINTZ, Ann; THOMAS, Selma. The Virtual and the Real: Media in the Museum. $2^{a}$ ed. Washington DC. American Association of Museums, 2000. p. 1-17.

VALLE, André Alves de Lima do. Narrativas Transmidiáticas: aprendizagem, comunicação e estratégia de conteúdo em iniciativas multi-plataforma. Dissertação Apresentada ao Programa de Pós-Graduação em Estudos LinguísticosLiterários do Departamento de Letras Modernas da Faculdade de Filosofia, Letras e Ciências Humanas da Universidade de São Paulo. São Paulo, 2013. 113 p.

VAUGHAN, Tay. Multimedia: Making It Work. McGraw-Hill Education, 9 edition. EUA, 2014.

WILSON, Stephen. Information Arts - intersections of art, Science and technology. London (England): The MIT Press, 2002. 945 p.

ZANINI, Walter, $A$ arte de comunicação telemática: a interatividade no ciberespaço. In: Ars revista do Depto. De Artes Plásticas da ECA/USP, Vol 1, 2003. Pág. 10-34. 


\section{Apêndice}

\subsection{Entrevista com Pedro Paulo Rocha}

- Realizada dia 20/07/2016, na FUNARTE/SP, Alameda Nothmann, 1058 Campos Elíseos, São Paulo.

- Gravação: Paula Maciel.

- Edição: Denise Vieira Pinto.

- Transcrição em linguagem falada de entrevista gravada em vídeo.

LUCIANA: A entrevista é com o Pedro Paulo, hoje é dia 20/07/2016... Pedro Paulo é um artista transmidiático, que trabalha com cinema e uma série de outras mídias...

LUCIANA: Pedro Paulo qual a sua formação? E em que você está trabalhando agora?

PEDRO PAULO: - É... Eu me formei em Imagem e Som, né? Então mexe com Comunicação Social. E na Universidade teve um momento em que eu rompi com a Academia, rompi com a sala de aula, com a divisão disciplinar, a gente precisou criar uma universidade livre na experiência. E eu digo que a partir desse momento, começou que uma formação transdisciplinar dentro da própria Universidade. Eu tive contato com a Arquitetura, Design, com Arte-educação, com a intervenção de Humanas e surgiu uma série de outros territórios, que não eram mais determinados para disciplinas da formação acadêmica. Mas pelo encontro, por todos esses fluxos que vinham com fragmentos, como fractais desses lugares que eram muito essenciais, inclusive a partir de momento que comecei a trabalhar com a Translinguagem. Onde tudo era fluxo, sistema poético de fluxos... Éhhhh?... Foi essa pergunta?

LUCIANA: Foi... (risos)

PEDRO PAULO: Então eu digo que minha formação é um movimento de tempo, um movimento constante, constante movimento.

LUCIANA: E quando foi que você se interessou pela Arte Digital, e por quê?

PEDRO PAULO: É.... foi na época que desconstruiu o Cinema, né? A partir da ideia de dispersão do Cinema, tentando implodir o código do Cinema e o corpo do Cinema, se pode chamar de Cinema expandido ou Transcinema, né? Nunca gostei das categorias, e as 
categorias de Arte Digital, elas sempre foram capturadas para a Academia, e serviram de moeda de troca para instituições culturais...

É que o nosso país é um paradigma, onde não poderia ter paradigma algum. Esse Brasil está virando uma espécie de nova moda, que eu acho que acabou segregando a Arte Digital de outras áreas, né? Então eu não gosto muito dessas... Prefiro poética de fluxo, né? Mais híbridas, e acho que a própria nomeação, o próprio poema gera algo pra matéria expressiva, pra matéria, para transbordamento, uma possibilidade assim de luminar de qualquer tipo de paradigma. Então eu suspeito sempre dessas determinações "praguismáticas" que eu mesmo sofri, por não fazer uma arte que coubesse nem no Cinema, nem Arte Digital e neste tipo de rótulo. Eu também sofri um pouco de negação, acho problemático, você acaba criando territórios de separação, por mais que seja dito que tudo isso é uma mistura.

O que é Arte Digital? O que é Pichação? O que é uma arte "full"? O que é uma arte sem suporte? Uma arte sem formato? Quer dizer uma arte que não existe ainda... né? Eu me inspiro muito, mas não me excita que vem de um movimento, mas faz uma série de tradução eletrônica do suporte, mas não tem mais suporte, não mais obra, é o puro acontecimento... Né?

Estou agora dentro do tempo intensivo inventando as possibilidades. Então na ideia do cinema, de sair do cinema, de expandir o cinema, eu comecei a perceber que eu poderia criar máquinas abstratas, de puro sentido, sem nenhum tipo de fixação, como se fosse pichação, como se fosse uma "fracterização"...

Qual o menor tempo da imagem visível? Qual o tempo da imagem quando eu pisco os olhos? É assim uma imagem atômica, uma imagem explosiva. É uma "fraternização". É de mais entender o código, enfim, da tradução. Como o movimento pode dar sempre uma potência de um gesto, como um pichador uma improvisação de um rap, como uma filosofia um ato, né? É independente de qualquer tipo de suporte de ideia de artes, como se a própria ideia economizasse o nosso gesto, como se tudo já tivesse um nome prévio, um nome para ser visível e catalogado, como se tivesse determinado, explicado pelo pensamento.

Então acho que o imaginável e o fluxo livre do corpo diante de todos, da vida, é algo, que é muito mais potente que qualquer ideia de arte, de formato... Então eu comecei a perceber que a tradução era infinita, a tradução, a transdução é infinita, entre pensamento, matéria e corpo. "Oscipridade". Eu segui numa ideia de virtualidade radical, quer dizer, hoje 
eu me "apessego" no teatro hacker, que não é teatro, é uma performatização da ideia de teatro, para um público espécie de retrato expandido...

Aqui eu organizei muito teatro hacker, realizei no Parque Augusta, realizei um desempenho no Itaú Cultural, também em Junho de 2003 que propus sequestrar os ingressos, passava a apresentação num antiespetáculo, em que eu não apresentava nada, eu simplesmente usava a tecnologia que eles alugaram, para jogar contra o público, e dizia que a gente ia ocupar o prédio do Itaú Cultural, e a partir de uma especulação virtual, você tinha uma série de desdobramentos reacionais, reações das pessoas que faziam até parte automaticamente da dramaturgia da performance, como se ... Um furo na realidade né!

Então minha obra é uma obra de tradução infinita, hoje inclusive trabalho com pesquisa de análise, faço expressões performáticas, peço as pessoas realizarem expressões performáticas também, e acontecem ali cinco cenas durante uma hora. Então eu acho que arte é viver o tempo intensivo, do que da intensidade daquilo que se move né! $E$ eu acho muito mais que botar tipo um suporte, então é uma coisa assim pós, é o transmitir, que é uma forma que você transmite, mas é uma serie de possibilidades poéticas e nomeais (sic), é interessante você ter essa série de possibilidades, de não ter mais paradigmas, de forma científica, de entender aquilo...

Porque fica aquilo na Academia como se tivesse refletindo, entende? Uma coisa... morta. Então como que no pensamento a Filosofia pode se infiltrar? Mas a parte da matéria poética pode traduzir outra forma de pensamento, um pensamento que não tem nome, interessante isso. Então eu trabalho hoje com uma zona de "performatizações", de acontecimentos, por isso eu acabo atuando numa desconstrução do Ativismo, mais moralista... Que acho que a Arte é uma espécie de... de decoração, como se arte fosse um tipo de função determinada já portada. Então eu vou do Ativismo, ao desempenho, à tela, teatro virtual também cria os personagens virtuais, então implosão do campo da arte livre, mesmo né? Uma espécie como se, medida que no fundo descrições, já captaram isso numa forma de saber, esse corpo eletrônico, esse corpo semiótico, ele já... Se transbordou, ele muito veloz, todo mundo tá criando algo, que é? Desde um gif, eu acho que é mais uma criação de acontecimentos, esse suporte que ficou... É... Ele ficou felizmente, algo ultrapassado.

Ele não existe mais esse suporte, existe uma espécie de opacidade, transparência do próprio acontecimento... Que você e aquele outrem que tá em relação com aquilo que você fez tá no mesmo ciclo. Então não sei... Eu gosto muito de pensar na explosão disso e 
que não existe mais território, nem existe mais arte, existe aquilo que não existe, né? $\mathrm{E}$ aí que é isso? A arte virou uma espécie de... Morte do Fantasma! De opressão do Fantasma!... Isso que não existe, existe, acho que não existe continua como se fosse uma cápsula zero, que não existe, mas continua, ou uma substância que você prova a sensação, mas a reação, um corpo sem obra mesmo.

LUCIANA: Hum!Hum!!

PEDRO PAULO: Certo! (Coloca os óculos escuros)... Se eu não... se eu fugir muito você me diz! (risos).

LUCIANA: Não! Tá tudo bem! Seus trabalhos, você lançou mão de técnicas transmidiáticas. Quais seus trabalhos favoritos dentro desse tema?

PEDRO PAULO: É que eu digo que minhas obras, eu trabalho numa obra player. Eu traduzi, fui traduzindo a ideia do cinema, fui traduzindo em vários corpos como se fossem uma... Como se fala? Quando você abre? Abre, vai cortando o morto tirando as partes todas...

LUCIANA: - É desconstrução?

PEDRO PAULO: - É, mas tem uma... Coisa de cortar assim... É esqueci o nome... é "decantação"...autópsia... Uma tradução infinita, um infinito mais ainda. É então uma obra player, não vejo mais trabalhos, porque foram todos, são todos infinitamente possíveis de serem retomados e traduzidos.

É como se a ideia de desconstrução, expansão do cinema tivesse uma série de marcas abstratas, um labirinto tipo onde pudesse surfar agora, então tem uma, um campo de... Como se fosse uma memória eletrônica... Então se compõe essa memória eletrônica viva e que você vai vendo a obra a partir dessa memória, do futuro dessa memória, do futuro e o bum dessa memória. E é assim, tem banco de dados, é como se memória tivesse aqui (aponta para trás), mas tivesse sido projetada (aponta para frente), de tal forma que você, que você só pode criar o futuro a partir de um esquecimento, ou de um acesso errado a elas, ou tradução intuitiva mesmo, é como se fossem gestos, como um pichador que faz um movimento lá... tfhuuuuuuu!!! Que risca aquilo que ele nem sabe direito o que é, né? Então é obra player. Então tem vários trabalhos, transmitem a resposta da ideia do teatro hacker, foi aonde eu cheguei com toda ideia de desconstruir o cinema, foi um processo de montagem da tela mesmo, da montagem, então o filme já começa com ideias infinitas, daí 
tem os Cinemas, que foi o primeiro trabalho de montagem, que comecei com ideia do Malam, tem muita influência concretista também, juntei eu, o Glauber, o Hélio Oiticica, os concretistas com essa exposição da arte virtual, e eu fui recombinando filme, e de repente eu tinha um roteiro, que não mais dá ideia de fazer um filme, daí de repente eu tirei fot... Fiquei paralisando a imagem, tinham flames... Tá, Tá, Tá... Né?

Numa montagem dos flames, e dos flames eu começava a fazer uma espécie de "perfeição" do filme que não tinha filmado, esse filme estava sendo realizado. Então é uma espécie de mutação da própria maneira de falar daquilo né? Então como que eu posso, eu invento falar, campo virtual com vivência, vai possibilitando que eu vá vivendo, como algo inacabado, como uma plenitude, um milagre, né?

Interessante, muita briga toda batalha, muita batalha porque lá todo mundo luta. $\mathrm{O}$ Oticica eu acho que toda guerrilha que ele faz para desconstruir o suporte, para sair do espaço, para chegar num tempo puro direto, não tem mais a célula elo. Pode ser. Antes tinha preposições, nem tem mais né? Pode ser não achar também, até pode ser não achar. É como tá diante de uma tela, né? Se não atravessar por ela, apenas um high-fone, coisas que se tocam comentários que você faz, essa tradução, essa linguística, ainda linguística das redes sociais, é uma espécie de... De... Fracterização, tradução desse mundo virtual, um código escrito assim do próprio sujeito, como se fosse o sujeito passar para esse outro território tecnológico, para fazer essa tecnologia interfásica de uma nova expressão dele e do mundo, por outro ter que a própria linguística, própria fala, própria escrita, a própria ideia dele como personalidade, né?

Como nome, como imagem, tem que passar por uma espécie de fracterização, espiritualidade, é como se o mundo digital fizesse a própria digitalização da nossa própria... Subjetividade eletrônica...né? Eletrônica... É então o Kinema foi esse primeiro trabalho que descobri a montagem e remontagem, a remontagem do infinito, das coisas mais recombinando, eu fui traduzindo isso e criando, uma espécie de células tradutórias. Eu chamo de marcas abstratas, e foi me dando outros caminhos e obras novas que saíam dessa própria tradução, da própria desconstrução desse filme, então fazia parte desse filme, fazia parte de novas obras, é como se pudesse tá traduzindo infinitivamente um rio, tá no rivério constante mesmo, com menos bordas, como se o rio fosse uma linha e transformasse num Riomar até chegar ao mar, como se o rio se transformasse num mar, chegar ao mar essa largura do mar essas bordas que separam eles da terra, então do Kinemas eu fui criando, eu fui pra ideia do Lattes sigma, fazia imagens ao vivo, e pro Derivas Urbanas, daí seria atenção que eu transmito, né? 
Tradução da linguagem de si mesmo né, revoltar de telas, uma coisa intratela ainda quando eu vou pra performance, Lattes Sigmas tentando fazer derivas urbanas simultâneas, a projeção transmitindo, daí se pode dizer que tem uma espécie de transmidiação. Você tem a tela onde tá passando isso, onde tem as pessoas, personagens virtuais, você tem os personagens virtuais dando derivas para a cidade, transmitindo isso pra uma ação performática ao vivo, e a ideia de inserir uma performatização, rua, tela, local de performance de forma simultânea, como se fosse um bando pichando a rua até que venha pichar a tela.

A gente fez no MIS isso é, a gente fez também no Vídeo Urca. No Rio foi bem interessante, eram três dias de derivas, que eu ficava, eu ficava....com vários objetos pequenos assim, meio luzes, meio que projetores, cascas de parede, pedaços de pedras, pedaços de santos, coisas de testes que achava resíduos, e a ideia era eu criar uma poesia na hora assim, eu jogo então uma tinta vermelha, umas pedras e ponho uma coisa assim eu filmo e crio a poesia no gesto...Tááá'!! Instantâneo no momento em que nem conta o Iphone né? Você cria na hora assim... Páaá! Parece que tem, como um milagre, me vem assim, uma postagem, Tááá!... Uma pichação... Você tem essa coisa da compreensão do tempo... Dessa gestualidade, como se tiver tudo numa continuação de fractares, que vão se distualizando ( $\mathrm{sic}$ ), como rap, e você pode tá vindo, daqui, dali, você pode soltar isso em outra coisa, né?

É eu nunca falei desse jeito, tô bem inspirado pra falar de uma outra maneira de tudo que eu tô fazendo...Porque isso também se o pensamento pode ser essa estética, assim um estético, é o corpo perene que está sempre se transformando, é como se pudesse tornar o próprio pensamento estético. Então é uma abertura na própria linguística da teoria do pensamento, de se contaminar; então trabalho também dentro desta pro-filosofia também, a filosofia é campo do próprio pensamento estético, meio que construtivismo de condições possíveis que vão ser negados a cada nova, a novo experimento não empírico.

E o que é empírico? Algo inacabado, sempre uma infinitude, é sempre o infinito, sempre enigmas, de tudo que seria possível fazer, que pode fazer, daí tudo se torna virtual, torna o próprio virtual, uma dobra no virtual dentro dele mesmo; não o virtual que se separa do real, mas uma dobra dele mesmo e fure o verbo. Que fure o verbo contamine todas as linguagens, o corpo, a filosofia, as telas. E aí então eu estava falando do Fluxuz. O Fluxuz foi que eu fiz na do Rio. Foi uma outra, a primeira vez foi feita aqui no MIS, que eram os personagens da rua, pichando com a luz a rua, é com laser, com projeção, transmitindo para 
essa área performática dentro da sala do cinema, visor de internet, tinha internet era só a sala do cinema, o local de performance, tudo intercruzado como se fosse uma narrativa...

E aí no Rio foi o interessante, faz hoje, faz uma poesia, gesto no primeiro dia. No segundo dia, a gente projetou o que a gente filmou, uma projeção móvel assim num campo aberto, na rua, tá filmando, não sabe o que a gente vai encontrar. No terceiro dia a gente pegou todos esses objetos que a gente encontrou na rua, levou clandestinamente para dentro do ArtRio, porque a VideoUrb era uma parada do ArtRio, então a gente mapeou todas as obras de arte mais caras que tinham. A gente falsificou nossa entrada com cinco integrantes performáticos, levamos os objetos todos que eram objetos que não valiam nada filmados na sarjeta, filmados na beira da rua, na parede, qualquer coisa que a gente encontrasse no terreno baldio levamos esses objetos e espalhamos nas obras de arte todas do lado e a gente começou a fotografar isso, e quando foi dar o vídeo álbum.

A Polícia Federal me cercou, pediu que eu apagasse, começou a chamar atenção, eu disse eu disse é atividade performática, e aí eu comecei a falar que era uma arte fora do suporte, fora daquela história, só da minha performance, uma espécie de onde o virtual causou uma reação real. Que falei que não ia estragar o quadro, não ia quebrar o quadro, sujar o vidro do quadro. Ficou lá o objeto, né e aí, a única coisa que eu comecei a perceber foi a própria ideia do filme de que uma ficção pode ser infiltrada na realidade, ou é loucura? É potência virtual, potência do impossível, da imaginação, né? Provocação da imaginação contra a realidade factual, quanto mais a imaginação isso vem infinito, quando você tá assim introduzido, né infinitamente num jogo entre a realidade e a ficção, impulsão e o outro, da matéria e do gesto...É. Isso é uma coisa interessante que é presente na minha obra. Vou falar das minhas obras, tá?

LUCIANA: Claro, só peço para falar um pouquinho mais alto, que se não interfere aqui...

PEDRO PAULO: A obra, então ela transmite, ela é relações simultâneas, a tela depois eu vi que eu fiz a narrativa, a trans seria como se uma tela fora pudesse ter contato com uma realidade impossível ...Então naquele momento, a gente poderia ser preso pela Polícia Federal ter vindo, por causa do, de obra.

Quer dizer qual seria o valor dessa foto? Se é uma inversão num quadro de obra? Né? É... Daí a própria ideia de uma narrativa transmidiática, que tá ali só pros "aluizes", pros sujeitos de consumo, um sujeito que tá ali simplesmente, sei lá criando um lugar de pura vaidade. Mas eles não, é um lugar onde a rede coloca a gente também, de uma espécie de 
palco da identidade, palco da ideia, palco do ativismo, palco de tudo, de tudo aquilo que me torna um "Eu" fixo. Nunca muda as ideias.

Isso torna meio problemático porque, quero perder meu Eu, quero perder meu nome. Então é não o nome do outro, não quero ser fixo assim, esse sujeito, essa identidade começa, ser desatualizado, normalizado, é como assim objeto de arte, então como se vai pro deserto, o que tem nesse deserto? O que tem nesse espaço liso, extremo? Não é mais vértices, não tem mais suportes, tá transbordando, desconectando o tempo todo...

E esse ponto é interessante, no momento em que a narrativa pode se tornar uma narrativa entre tecnologia e forma que poderia deslocar esse sujeito, pra tá presente na subjetividade do campo virtual, dá pra ver todas as identidades da instituição, do sujeito, do curador, do artista, do pesquisador, entendeu?

Da tua câmera, todas essas coisas podem se deslocar. Eu posso pegar, a gente pode mudar de repente eu posso filmar ela me filmando, então essas possibilidades todas que eu acho que é interessante me propõem essa... tá tudo é o sujeito, não é só a base do conteúdo estético, não é a forma mas é esse novo, essa nova, esse novo "normatismo", pra especificar.

Então é que havia algo ali que era muito mais quente, muito mais vivo, que era sair dessa ideia, da performatização tecnológica, ter uma troca, ter um campo de provocação, um virtual possível, se não tá na tela, agora ele tá. O virtual saiu da tela, viralizou a realidade, então a partir disso eu comecei, eu falei: "eu não vou mais fazer arte sigma, ficar atrás do computador montando imagem, não vou ficar mais só atravessando conteúdos. Eu vou colocar, eu vou criar um personagem virtual, uma personagem virtual que atravessa a realidade. Daí surgiu uma carta aos velhos; a partir disso eu comecei a surfar não mais em obras. Eu percebi que eu tinha uma fracterização de linguagens e possibilidades, e daí todo aquele caminho de tradução do cinema, que eu percebi que não era mais assim do transcinema, do filme, não era o filme mais o significante, não era o pai o significante, não era mais o Édipo o significante, não era mais a palavra o significante, não era mais a ideia o significante.

Eram exatamente as máquinas abstratas, esse labirinto que eu criei para mim mesmo, esse labirinto de desvios, de ir e vir, de bifurcar, de desviar, de pausar, de não fazer, de caminhar na rua. Falei: Nossa! Olha só! Tem uma coisa muito mais direta, porque essa coisa eletrônica parecia um trabalho infinito, sobre a máquina, organização dos 
arquivos, virou isso, entendeu? E no final interativa o quê? É botão, e podia ser o controle remoto da sua televisão, entende! O que é a interatividade?

É o que tão fazendo nas instituições culturais. Eles estão lentamente transformando uma imagem de valor de troca, roubar, como capturar da academia para beneficiar as instituições. Não entendo o que tá rolando, qual a revolução nova na mesma linguagem. Então instituições são vitrines de morte da arte eletrônica e do eletrônico virtual, são os cadáveres do virtual, os cadáveres da arte digital, tão modificados, entendeu?

São tudo uma programação, uma ideia de consumo cultural, para eles manterem uma agenda cultural, então nunca ia se desmontar uma exposição do curador, do gerente do setor, do núcleo, de quem? Do advogado, que avalia os projetos, pra tá vendo dentro do orçamento, dentro do orçamento da instituição, se vai ser esse tipo de arte ou outro tipo de arte... então, olha só, tudo misturado, uma estética uma forma da semiótica e da burocracia. A semiótica é uma palavra, existe uma norma semiótica, que vai dizer o que é arte o que não é arte, e se é arte digital, se é arte performática, e entra naquele mercado de artes, é uma ilusão, é uma espécie de você transformar o processo para o mesmo conteúdo, né?

Então, quando eu soube sair desse campo da performatização, da impedição, dos editais, da ideia de fazer um projeto, uma antropologia do que eu faço, uma organização, paragrafar o que eu faço, eu comecei a sacar que era o gesto, era o tempo intensivo. Não tem mais o suporte, não tem mais nada, pode ser tudo né, dessa saída assim interrompendo esse processo, trazendo o antiprodutivo dentro da máquina que faz. Então faria disso a arte digital, eu faria o avesso, dentro dessa repetição, fazer algo que não funcione, faria uma performance que não será realizada, ela pode acontecer tudo, o que pode acontecer?

E ai então que acontece o desespero, que vai acontecer? Será? Que vai acontecer? Por exemplo: a performance que eu vou fazer aqui. Minha obra de arte é em cima do dinheiro do leilão, vou fazer uma perfomatização virtual em cima do valor do dinheiro, ou seja, dou convites, tentando multiplicar o dinheiro a partir empinaste, entre colecionadores do mundo todo, que o cara vai ligar ao vivo e comprar uma obra que não valia nada por um valor absurdo e assim vai conseguir multiplicar gradativamente esse dinheiro, então é um virtual incandescente onde tudo é possível, tudo é lindo, tudo é composição, tudo é cruzamento...

Eu saindo da coisa móvel interativa, interativo limitado, eu percebi que tudo era performance, performance permanente...É, eu cheguei com o Teatro Hacker, ideias visionais e achei meio aberto de ação direta da minha arte, fiz alguns movimentos culturais, 
os movimentos onde as zonas da cidade, você pode encontrar pessoas de todo tipo da cidade, uma pessoa que é um morador de rua, uma pessoa que é um artista, é um guarda, uma pessoa que é um filósofo, um pichador, um rapista, é uma funkeira, a aí você mostra isso na tradução intersubjetiva, dentro da tradução semiótica. Não é a tradução dentro do suporte.

É aí que você vai e cruza com tudo, e aí você cruzando tudo tem uma tradução do sujeito no mundo, não tem uma tradução numa linguagem isolada do mundo. Talvez precisa até da linguagem do mundo, mas isso é subjetividade que traduz também essa linguagem que são os pontos. Esses encontros vão criando esse corpo semiótico. Não é uma coisa em si, é se a linguagem estivesse na subjetividade também, que é na área estruturalista o objeto em si também. É um tornar o sujeito à arte, não que precise de uma bibliografia, da história do sujeito, do sujeito se tornando arte, sendo desvio da própria arte, uma arte expandida de si mesmo, né?

Então eu acho que tem a ver com o poema, estado de poema, da imaginação mesmo. Eu vivo da ideia de fazer uma série de projetos, eu fui fazendo essas performances, eu fiz Versus Black, o Cápsula Zero, que foi no Itaú Cultural. Fui fazendo performance que eram cinemas, transando o espaço e dimensão. Eram situação que induz ir pro Parque Augusta. Era um terreno vazado, levei pro teatro Oficina, comecei a provocar umas situações lá na frente, com a ideia de derrubar os muros do terreno. Derrubava os muros do Parque Augusta, pra não ter mais entrada ou saída do parque, dei uma luz no parque no terreno do Silvio Santos para fazer com que essa luz possa se expandir e vazar pela cidade...

Então é uma das performances que se tornaram vitalidades incandescentes provocando o real. Que pode acontecer? A partir disso, vai rolando as reações, Terreno vazado e aqui eu fiz o Abro, aqui no teatro RioMar. Vou falar dessa ocupação, que é um espetáculo infinito, que acontece a partir que o público chega. As pessoas, então... Duravam seis horas em que as pessoas iam improvisando, se apoderando da possibilidade de estar no palco. Elas sofriam uma espécie de resposta do público, que tirava ela do personagem dela, toda representação teatral dela, ou de um teatro social, que ela está representando num gênero. Ela é uma espécie de que o público devora totalmente a cena, as cenas são destruídas, desconstruídas, então existe uma espécie de situação no palco vazio e público, cena um o que pode acontecer. 
E aí eu até tenho uns players que são uns jogadores que vão controlando as situações, e vai surgindo tudo, tem um determinado momento que os próprios ativistas têm que subir no palco e responder o que estava acontecendo na performance. E eles ficavam sonhando, à noite, que estavam no palco e acordavam em casa fazendo a cena sem saber completamente se estavam no palco ocupando toda realidade da ocupação.

É uma espécie de deslocamento, e foram vários trabalhos nesse sentido, tem Art Black, Terreno Vazado, e... Essa última coisa eu fui traduzindo e aí tem a poesia também. Quando eu fui traduzindo em filme, tem esquema performático, e eu fui continuando nesse campo de tradução, no campo performático, Teatro Hacker, performance... Eu vou misturando todos os conteúdos, que eu vou criando. Faço a tradução dos cortes do filme mesmo, tem combinatório, tem flames, e overflames, personagens fotografando as fotos que eu faço, eu fiz também outras fotos de flames em movimento, mas como se fosse uma cosmocopia de cinema, de tela e gestos, tic, tic, tic, tic.

Então isso era, eu quero falar que tem a performance e a tradução da linguagem semiótica, tem uma série de caminhos de tradução, como se fosse do próprio cinema, eu fico criando, enfim... Tem a infra poesia sonora, da escrita e ai surgiu Work Flames, daí surgiu a matéria Glitica, comecei a traduzir isso para o material plástico. Faço então há dois anos.

E aí então eu falei: Nossa! Que interessante, tô indo agora para o orgânico! O que esse orgânico tem a ver com o eletrônico? O corpo nem existia. E ai eu falei: Nossa! Então eu vou fazer o caminho totalmente contrário, eu vou achar o eletrônico onde ele não tá, então depois tentei fazer todos os caminhos, monte de obras vivas, em que eu vou buscando elas.

LUCIANA: E esses fragmentos você acabou convergindo em uma obra?

PEDRO PAULO: Então, ele vai aumentando o labirinto, surgiram talvez performance que acontece em dois dias e de repente não realizava mais, mas eu posso ativar. Não existe obras finais, vejo como obras que estão eternamente num ciclo que pode ser reativado, como se não tivesse nem passado nem futuro.

LUCIANA: Entendi... E que tipo de mídia em geral você costuma usar para suas obras além do cinema? 
PEDRO PAULO: Todas, né! Todas as mídias. É o gesto, por exemplo. As que eu uso mais é a esquizoanálise. Nos encontros performáticos, tipo atos cênicos, cena um o sujeito tá falando com ele mesmo. Por exemplo, que matéria é essa? O virtual, eu uso o virtual e todas as matérias possíveis, essa conversa pode ser uma esquizoanálise, eu tô falando aqui a primeira cena pode ser uma cena realista, a pessoa vai falando eu vou perguntando, eu tenho usado muito a quarta cena... a cena a dois eu troco de lugar com ela... eu e você...daí você põe o meu óculos, eu ponho seu óculos, daí eu te entrevisto.

Eu falo daí, e você começa a fingir que sou eu, eu finjo que é você, daí isso vira uma duplicidade, daí cena quatro.... Na cena três é uma espécie de fala do inconsciente; então é uma cena no estado zero, num lugar muito zoom no imaginário, mas eu falo... Ah ...liberdade total, desconstruindo a linguística, né? O próprio corpo, a própria estrutura da linguagem, um poder sendo desconstruído, que prende o sujeito em ilusões mesmo, de uma vida separada de si, separado do próprio conhecimento, um negócio de não suporte ao acontecimento. Você não tem suporte, não suportam, não suportam mais, não me suporte para iniciar além do suporte, então é um acontecimento, é provocação. Aqui vai ter muito suporte politicamente, né! Então é um corpo, é o outro, esses suportes convencionais que a gente usa, a poesia, eu procuro o código entra a poesia e poema...Éééé'...a filosofia vira suporte também, a própria palavra, a marca, a máquina de falar... Né? É tudo isso ...

LUCIANA: Na sua concepção, o que é um artista transmidiático?

PEDRO PAULO: Ah!! O artista transmidiático é um artista, é um furador de ondas, um percolador... Um... assassino de realidade. Não gosto muito de denominar tão pouco assim. Não é só um movimento entre as mídias é uma... É uma...um virtualizador de virtualidade...

LUCIANA: O que você acha que a transmídia proporciona para a obra de arte e para o público?

PEDRO PAULO: É o fim da obra de arte e o fim do público...

LUCIANA: Ou seja, um faz parte do outro no fluxo constante?

PEDRO PAULO: ...fluxo constante...

LUCIANA: E ao todo, reinvenção...

PEDRO PAULO: É o público em obra de arte. E a obra de arte pública... 
LUCIANA: Você acha que atualmente o público valoriza mais uma obra onde possa atuar ativamente ou observar passivamente?

PEDRO PAULO: É.... acho que o público... o público...não existe...acho que o público valoriza na verdade o passeio dele... Acho que esse público...quando o público não existe mesmo, acho que a gente vai tá num outro tipo de valorização mesmo, aquele momento estético mesmo, ...os museus são lugares mórbidos... Não é que eles são cemitérios. Eles são cemitérios. Não é que eles se pareçam, eles são mesmo cemitérios... Não sei que sentido que pode ter uma obra de arte num lugar que não tá vivo...

LUCIANA: E você tem percebido a Transmídia como uma tendência dentro cenário artístico nacional ou internacional?

PEDRO PAULO: É uma realidade do cotidiano, mais que uma tendência, né! Talvez não consiga acompanhar, tudo emergido dentro dos meus simulados, tão falando tanto dessas ondas, que eu nem consigo saber também. Essa tendência é complicada. Seria uma resposta, sei lá, uma resposta, assim, abstrata...

Que as respostas que eu dei, pode ver, foram completas! Mais o quê? Eu não sei, acho que ela, a Transmídia, é o cotidiano, é o cotidiano. O que eu percebo é que... não tem como às vezes não capturar a transmídia, sem não marcar as instruções dela mesma. Se ele existe mandamento de público, tipo obra de arte, as possibilidades de romper com essa condição de obra de arte e público, meio uma ideia de uma coisa parada no tempo, exposta num quadro, não terminada, não tem mais como ter nem exposição. Como é tempo virtual, ela é o tempo virtual. Então eu fico me perguntando: Como que vai virar uma tendência? É uma tendência? Ou se não é só uma captura de algo que tá muito mais no cotidiano... as instituições tendem a chamar pro próprio cotidiano para capturar, então uma espécie de lugar de mercado e de alienação daquela experiência, um 'Viva!', começa todo mundo hoje querer a transmídia... Né? Só isso mesmo!

LUCIANA: Como você vê a relação da crítica e do mercado com as obras transmidiáticas?

PEDRO PAULO: Como estava dizendo, eu vejo trabalhos, meus trabalhos, totalmente incompreendidos. Trabalho que foi pouco, mal compreendido em várias situações, que causaram praticamente fofoca, desentendimento, ignorância total, dos curadores, das instituições. De povo que vive da arte, que não capta o que eu tava falando, de tá sempre furando as ondas, tá sempre provocando uma viralização do virtual, virtual no 
real. Isso então me levou pra um abismo praticamente, como se não fosse nenhuma obra fixada no tempo, com valores positivos, uma ideia de programação cultural, como posso dizer, da minha obra.

Eu já li algumas coisas, algo que não tem como não ser uma situação: a transmídia, uma conexão nova que você faz, é um ajustamento novo que você faz, redescobrimento e envolvimento de tudo, né!...tá...tá...tá...tá....é como uma "ritmia"... é novidades, o agora, que a gente pode fazer, pode virar para cá, não mais uma deriva, não tem como você ter um mapa pronto. Então o que eu vejo é incompreensão com relação a esse novo, como se ainda... Por isso que é contraditório, a questão do, dessa absorção da arte digital, das tecnologias nos institutos que têm uma estrutura burocrática, "antimidiática".

Que dizer, então... se a própria arte não vai transformar essa relação da semiótica do espaço, poder da contração do espaço, ajustamento do tempo, os corpos, os acontecimentos, fixações do tempo mesmo, eu poder tá falando aqui durante horas e não existir tempo, entendeu? Acho que uma floresta muito mais transmidiática do que uma exposição de arte mídia, ver uma deriva na rua, um passeio pelo Facebook...é muito mais cheio de emoções e possibilidades. Então acho que existe uma, uma devoração que tem que ser feita da tecnologia, uma barbarização que se tem que fazer das instituições, do tempo. É isso que é o virtual. Então, pra mim, isso é um abismo entre o tempo morto da instituição, a ideia da forma de organizar isso, conceito cartorial e o que é o virtual transmidiático, que é o real, que é a cidade, agora em vários canais ao mesmo tempo, ...zum...zum...zum...

Há uma grande contradição, tão simples e importante do próprio trabalho de saber sobre isso... Transmitir, porque ela tá no cotidiano, creio que presa nesse consumo de identidade, de palco, de identidades fixas, onde cada um tem sua ideia, cada um sabe o que é, se fechar da autoridade de outro e esse lugar que ela é simplesmente transformada em moeda de troca, para as instituições culturais anacrônicas criar uma simulação.

Isso tá separando dentro da cidade, de um lugar mais expansivo como se no fundo, colaboração para situação de ensino para as pessoas darem aulas, formas de controle do tempo, da produtividade, da norma, da cobrança, da exploração do trabalho, da própria semiótica do Estado. Tá falando disso, quer dizer, a tradução política da linguagem, pra distribuição do poder, do acontecimento. Essas formas de prisão são as instituições, um transmídia significa uma nova possibilidade... Então como teria, como seria, se as instituições ... e ainda a transmídia significa a revolução dessa forma de comunicação que 
desdobrou outra lógica de acesso dos espaços, de participação, da democracia, da transmídia por democracia. Imagina não precisa ter um estado, não precisa ter um edital, os caras que fazem rap podem se conectar a ideias ao aplicativo, transformar em instituição cultural, potenciar capital, não precisa escrever, por exemplo, não precisa trabalhar mais .. tá tudo em movimento, está no floor, na cross....

LUCIANA: Para terminar, tem os dois projetos que eu vi na internet Conectivo Tranzmidia e o Transmídia Festival Virtual Permanente. Você pode me falar sobre eles principalmente o Festival Permanente que está para acontecer?

PEDRO PAULO: É, isso foi um projeto que a gente realizou. Anterior a esse projeto na verdade, eu tava pensando na ideia da universidade livre sabe, transmidiática, que seria uma de transformar o tempo virtual e o tempo real num devir, onde não existe mais uma, fazer aquilo, fazer isso, cê já tá no tempo, tá em movimento, tá no acontecimento, como a vida quando você acorda, você vai, você lava o rosto, toma seu café. Como esse tempo influi em tudo. Entre estar no tempo, na potência do acontecimento, ele se liberta da contagem. Num sei. A ideia do festival era isso, essa ideia da perda do permanente, de a transmídia ser uma instalação desse tempo infinito, desse estar no tempo, desse estar em movimento... Qual foi o outro que você perguntou?

\section{LUCIANA: Conectivo Transmídia?}

PEDRO PAULO: É, exatamente. São tentativas de transformar o estético, a linguagem, essa coisa que nós falamos, estado da obra player num campo também social, né? São traduções transmidiáticas da arte na estética. A gente tá falando de uma transformação total das coisas, não só de uma, do objeto da arte, ou do saber sobre isso; a gente tá falando de uma, de um humanismo, configurações de espaço e tempo, como posso dizer, não tem como a gente não pensar o político dessa revolução tecnológica, sem pensar que o social pode transformar a arte desse campo virtual, onde o que reina é sempre a poesia da subjetividade, o delírio do sujeito. Então por que não tem políticas públicas pra isso?

LUCIANA: Obrigada.

PEDRO PAULO: Obrigado você. 


\subsection{Entrevista com Bernardo Galegale e Gustavo Vaz}

\section{Membros do ExCompanhia, criadores e diretores da peça transmidiática "EU- Negociando Sentidos".}

- Realizada dia 28/07/2016, na residência de Bernardo Galegale.

- Gravação e edição: Fábio Goulart.

- Transcrição em linguagem falada de entrevista gravada em vídeo.

LUCIANA: Que dia é hoje mesmo...?

GUSTAVO: ... 28 de julho, quinta feira...

LUCIANA: Então, 28 de julho, quinta-feira, 2016, essa entrevista é com o Gustavo e com Bernardo do Grupo EXCompanhia... E bom...

\section{Gustavo e Bernardo qual a formação de vocês e em que vocês trabalham} agora?

GUSTAVO: Eu? Porque eu começo? Hã!! Eu sou formado como ator, eu sou do Rio e eu me formei na Escola de Teatro Martins Penna, que é uma espécie de EAD, do Rio...Hã...somente isso...e agora...Putz! Muita coisa assim, além das companhias que, de um tempo pra cá, começou a tomar mais tempo nosso. Trabalho como ator, e tô em cartaz. Agora tô começando a escrever coisas, trabalho com produção também, tô começando a fazer dublagem... putz...dirigindo um monte de coisas...

BERNARDO: Eu....fiz minha graduação em Ciências Sociais, lá na USP LESTE. Depois eu agora tô no Mestrado, né? Mestrando Ciência da Informação na ECA e putz! Com trabalho são várias coisas, né? Então tem a ExCompanhia que somos os diretores, tem o Teatro Centro da Terra, que eu sou assistente de direção lá! Porque eu fiz um curso técnico como ator, mas nunca trabalhei profissionalmente, tive muitos...

GUSTAVO:... Muitas...

BERNARDO: Como que eu falo, estímulos a não atuar por alguns amigos, ou seja, não era um ator muito bom. É, mas aí eu comecei lá Teatro Centro da Terra e tô até hoje lá como assistente de direção nos projetos etc...Hã que mais...Ah! Faço também, Produção Cultural em geral... assim desde produção de eventos. Então acho que é isso aí.

LUCIANA: Ok! Quando foi que o Grupo EXCompanhia se formou e qual foi a proposta inicial? 
BERNARDO: Se formou em 2011...

GUSTAVO: Começou a se formar em 2011, né? A gente...começou com um grupo de estudo e pesquisa que tinham mais algumas pessoas e com o tempo, isso foi meio que .. aconteceu uma seleção meio que seleção natural. Acabamos ficando nós dois e esse grupo. Acho que na época tinha a ver com inquietação nossa, principalmente sobre teatro... Né?...(OLHA PRA BERNARDO)..eu acho...É de onde a gente vem, né, onde eu acho que, eu mais trabalhei também o teatro... e... acho que também a gente sempre fala isso por trabalhar no Centro da Terra com o Ricardo Karman, que é um cara que acho um dos mais importantes aqui de São Paulo nesse trabalho de multimídia, e também com espetáculos fora do teatro em espaços não convencionais, etc. Isso acabou influenciando muito a gente assim nesse pensamento sobre a experiência teatral, a qualidade da experiência teatral e porque que a gente especificamente, pessoas de teatro, homens de teatro, achava o teatro tão chato... Assim é. A gente começou a perceber que tinha a ver com uma...uma....uma discussão necessária sobre o tipo de experiência que o teatro proporciona para as pessoas hoje em dia assim...e acho que foi a partir disso que a gente começou a pesquisar algumas coisas e o Bernardo trouxe um artigo que eu acho que cê pode falar melhor...que acho que foi a base do pensamento das companhias...

BERNARDO: Que foi o Notas sobre experiência do Bom Dia. Já deve ter lido alguma coisa assim. Foi de um educador, né, ele fala justamente agora do Século XXI, a diferença entre você passar por uma experiência ou você ter uma informação sobre alguma coisa assim... e ele discorre e fala como que é a experiência vem sendo deixada de lado e a gente partiu desse pressuposto na ExCompanhia como o teatro a grosso modo assim mais na raiz; e é um encontro entre pessoas, ele se dá ao vivo...ele não é...então como que a gente conseguiria a partir dessa pesquisa que a gente começou lá atrás, a discutir várias coisas, os autores etc. Mas como trazer isso no foco do trabalho artístico do teatro que é como você faz dessa experiência ao vivo uma experiência mais conectada, sei lá , com a nossa época assim.

\section{LUCIANA: Quantos integrantes fazem parte do grupo no momento?}

GUSTAVO: É, então... É assim .. Porque assim a gente... O nosso trabalho de companhia, é um trabalho...inclusive a ideia do nome surgiu... porque a gente também discutiu um pouco esse mecanismo de funcionamento de teatro assim...né? Então efetivamente quem trabalha com a ExCompanhia somos nós dois, então a gente é um duo, mas a gente tem artistas que entram sempre nos projetos que a gente faz que são, acho que... 
BERNARDO: ... O Thiago, a Bárbara, a Camila, o Dani, Jonas, Gabriel.; ...

GUSTAVO E BERNARDO: Então, são em oito.

BERNARDO: Se tiver que construir um núcleo assim, somos em oito, embora assim nós como diretores dessa companhia, a gente que pauta os projetos, a gente que pensa nas nossas, nossos caminhos de pesquisas etc. Então quer dizer nós temos na prática reuniões sempre e depois a gente começa a agregar esses artistas que são amigos e que fazem parte do projeto sempre.

\section{LUCIANA: Para vocês, o que significa transmídia no universo artístico?}

GUSTAVO: Você que agora tá estudando isso... Arrasa na resposta.

BERNARDO: ....No fundo assim o transmídia... Ele surgiu por causa do... o Rui Xavier, que é dramaturgo, que é um amigo e que participou com a gente dessa. Ele foi meio que um consultor de dramaturgia quando a gente fez o "EU - Negociando Sentidos"... e ele que trouxe essa palavra, a gente desconhecia totalmente. Quando a gente já tava ensaiando acho que foi o Rui...

GUSTAVO: Acho que foi o Dani, hein?!...Começamos a discordar...

BERNARDO:...Não, mas, não sei se foi o Rui ou foi o Dani...mas no que a gente já tava pensando nesses sentidos que a gente ficou muito tempo eu e ele se reunindo, e pesando num formato assim, que fosse além do teatro convencional, e aí a gente foi começando a trabalhar com os atores da dramaturgia e, a princípio, a gente não tinha nada de espetáculo multimídia. E que a nossa escola lá com o Ricardo Carmo, ele sempre teve esse termo muito forte...hã...Só que aí chegou o Dani e o Rui e falaram: "Vocês já ouviram falar desse termo transmídia?" E aí a gente, não! Aí ele contou um pouco e a gente falou putz! Tem tudo a ver com que a gente quer fazer no... que utilizar dessas plataformas variadas de mídia, pra tentar integrá-las dentro de uma mesma narrativa. Depois que a gente acabou se debruçando mais, pesquisando mais, a gente viu que não é um conceito muito bem definido assim, pelo menos no meu ponto de vista. Tem trabalhos que eu vejo que, tem muito na publicidade, né? Coisas que são transmídia, eu não acho que são tão transmídia. Eu acho que na verdade existe uma, um deslocamento de uma plataforma pra outra, mas não de uma forma que isto esteja integrado assim, dentro de uma linha mestra assim. Mas eu acho que como um conceito artístico. Na minha opinião, que é isso de você se utilizar de mais de uma plataforma...é nosso caso. Até acho que tem tudo a ver com tecnologia e mídia tudo em geral, mas de uma maneira onde elas não sejam 
interdependentes então se eu contar essa história eu preciso dessa mídia, dessa mídia e se eu tirar uma descaracteriza...

GUSTAVO: É que a plataforma é necessária, né?

BERNARDO: É.

GUSTAVO: E não são uma expansão de... da coisa. Ela é necessária

BERNARDO: É.

GUSTAVO: Ela foge à base narrativa da dramaturgia, perde seu sentido e o entendimento sobre a coisa.

BERNARDO: É... Isso afeta a essência da própria proposta artística

GUSTAVO: E as plataformas no nosso caso... Elas, acho que elas meio que surgem durante a criação da obra. Quando a gente pensa... eu não sei a gente não tem um processo meio que muito claro, se primeiro vem o tema ou uma montagem, uma ideia mas, quando a gente percebe essa plataformas se fazem necessário pra chegar no tipo de experiência que a gente quer propor...e ai quando a gente vê a gente fez mais um trabalho de multiplataforma.

LUCIANA: Acabou ficando diferente do tipo de abordagem que o cinema faz? Porque a ideia do cinema é que as plataformas se comuniquem mas que elas sejam independentes entre si só...dentro da obra artística. Vocês acham que elas não só são multiplatafórmicas? Devem coexistir, devem fazer parte...

GUSTAVO: É que assim o termo Transmídia faz sentido... Nesse sentido, quando elas dependem uma das outras, porque, acho que tem a ver com uma coisa que eu acho que é ... Não sei se tem a ver...essa ideia tá me vindo agora que é ...a gente falava muito sobre o tipo de teatro que devia e até faz, fazia... que é o teatro muito de exibição...assim sabe ..tinha muita coisa ali mas você não se envolvia profundamente com a experiência teatral... e acho que quando você é a transmídia nesse lugar de várias plataformas mas que não são dependentes vira também uma exibição de plataforma mas que você fala: "pra que isso assim...?" Sabe eu acho que é necessidade da plataforma, da iniciação de diferentes plataformas a nossa, meu, o nosso ver faz que o nosso trabalho seja transmídia e essencialmente e profundamente transmídia. Ou não... acho...

BERNARDO: Talvez até...uma coisa até...eu tô falando tudo assim, nunca estudei isso assim profundamente posso estar falando besteiras mas no meu ponto de vista, é isso 
é um elemento diferencial do multimídia... O multimídia significa que você dispõe de várias mídias para uma determinada coisa, o transmídia é o que perpassa, você vai fazer como se você...é ... Ligasse uma coisa na outra assim...sabe? E não fosse uma coisa em blocos, né?

LUCIANA: E quais critérios vocês usaram para escolher as mídias do projeto e como foi trabalhar essa poética da peça, usando essas transmídias?

GUSTAVO: Doeu, né? Efetivamente, um pouco da resposta anterior nisso assim, da necessidade, foi aparecendo, né?

BERNARDO: É uma coisa que a gente como... Que era um dos nossos pontos de pesquisa que era... essa relação com uma linguagem contemporânea. Como trazer isso pro teatro, não que o teatro não tenha, o teatro em geral, né, Gu? Legal que a gente sempre fala isso, a gente não é contra o teatro, é que nosso tipo de experiência com o teatro acabou indo para esse lado que...

GUSTAVO: Inclusive a gente faz, e gosta de assistir, mas era uma crise meio que, que a gente tava tentando identificar e percebeu que onde a gente se encaixava, nessa nossa crise...

BERNARDO:...E tem uma coisa que sempre foi uma pulga na nossa orelha que até o Ricardo implantou, o Ricardo Carmo, que ele fala assim que a gente tava começando com a companhia, tava começando com o trabalho e ele falou uma vez assim: "Olha na minha época... tipo final dos anos 80 começando os anos 90..ele fez as expedições experimentais multimídias, que era um, uma peça de teatro, onde tinham, vídeo, performance, o público participava, interagia, e ele fez num túnel. O túnel tava em construção acho que o túnel Jânio Quadros hoje em dia. Eles tavam em construção na época 92, ele disse assim: Na minha época eu senti que ao fazer esse tipo de trabalho eu me comunicava com o público de 92". Ele falou agora, 2012 onde a gente tava ...é...Qual que é artgasts (sic.) né? Como que a gente se comunica? E a gente nessa função, nessa pesquisa, uma coisa que tava na época bombando, mas mesmo assim sempre está nesses últimos tempos mas que na época era a questão das redes sociais que foi quando o Facebook ganhou uma força fudida de ...pode falar palavrão?

\section{LUCIANA: Tudo bem.}

BERNARDO: Uma força fudida, e a gente falou assim: "Bom, será que a gente consegue alinhar, se a gente pensar que o espírito da época gira, acaba tendo a rede social como elemento de referência. Então como que a gente usa dessa ferramenta, dessa linguagem numa experiência teatral? E aí a gente foi discutindo né, então...acho que eu tô 
na pergunta ainda né? Então por exemplo a escolha dessas mídias né? Eu acho que foi muito, a rede social em si foi muito por causa disso, um entendimento do tipo "tá, então vamos parar um pouco e vamos pensar o que a gente ta vivendo hoje em 2012"? E aí a gente viu que era uma coisa que fazia sentido de uma maneira de criar essa identificação do público com o que ele vai "experienciar" sabe?

GUSTAVO:... É tinha uma coisa também que tem a ver com a...a gente se perguntava muito sobre por que a gente acha o teatro chato, assim? E porque as pessoas não vão no teatro? A pessoa fala: "Vamos ver um filme", a pessoa fala "Vamos! Vamos, sei lá, vamos dançar vamos ver um show? Vamos! Vamos no teatro?" A pessoa fala "Ah, no teatro?" Ai! No teatro? Então porque isso acontecia e tal... é... então, o que a gente, que alguém pensou foi que a rede social era de alguma forma, começar num terreno confortável da plateia, começar com uma obra quase que dentro da casa, da plateia dentro da rede social e de repente ela já tava dentro de uma experiência de teatro, que assim, o degrau para o teatro fosse meio que imperceptível, e também isso apareceu numa época de falar meio óbvia, falar de rede social. Assim a gente começou a se olhar e perceber que as pessoas não falavam muito sobre isso assim e muito pouco ainda sobre internet. Acho que aqui no Brasil e no teatro, principalmente, a gente falou: "Como assim, né, uma coisa que é tão urgente, tão pulsante ninguém nunca discute o que ta acontecendo, essa relação e tal, né?" Hã então as coisas foram meio que ficando óbvias e fazendo sentido. Que a gente precisava usar essa plataforma de se discutir o que tava acontecendo e a gente passou um tempo quebrando a cabeça pensando em como fazer isso dentro de uma experiência de teatro e aí acabou virando que até hoje a gente não chama de espetáculo de teatro, mas experiência cênica inversiva, apesar de todos os elementos de teatro, personagem, até construção de gênios de personagens, encontro entre plateia e personagem ao vivo, história com início, meio e fim na narrativa clássica e tal... é difícil de chamar de teatro assim, inclusive acho que ninguém... Quem fez matérias na época, nunca chamou de teatro né?

BERNARDO: É, acabou sendo uma experiência com o teatro assim...

LUCIANA: Um teatro...experimental...né?

\section{BERNARDO E GUSTAVO: É...}

LUCIANA: E quais foram as mídias que vocês usaram, além da rede social?

BERNARDO: ...Bom a gente teve...esse projeto. Ele acabou se modificando com o passar do tempo. A gente foi apresentando algumas edições, e por ter um caráter muito processual, ele foi se aprimorando em certo sentido, mas além do Facebook, que a nossa 
rede social principal ali, a gente teve...a gente filmava todos os nossos encontros. Então, o espetáculo em si, ele durava quase um mês de duração e tinha alguns encontros presenciais com o público, né? E todos esses reencontros nas casas dos personagens que faziam parte da história isso eram filmados, pra ter um resultado em vídeo disso também, ...é ... além de, aí falando em rede digital além do Facebook em si, a gente começou a utilizar, mensagem de texto, WhatsApp, Skype. Aí, até ligação por telefone, e-mails, porque os personagens, utilizavam de todas as ferramentas que nós utilizamos na vida real com o público, né?.... Então quanto mais a gente conseguisse trazer esse dado de realidade para essa relação entre público e personagem, era mais eficiente, né?

\section{LUCIANA: E como é que foi essa interação do público com a peça?}

GUSTAVO: É, foi muito, foi muito potente. A gente depois de fazer a primeira experiência do $\mathrm{Eu}$, a gente colheu depoimentos das pessoas porque a gente precisava saber o resultado da coisa assim, né? A gente, eu acho que na época viu claramente, que a gente tinha uma sensação de estar, tá realmente descobrindo algo novo assim, sabe? No primeiro encontro que a gente fez, depois de uma semana duas semanas entre os personagens e o público, via Facebook e telefone ...o risco daquela coisa do primeiro encontro era tão grande que a gente não tinha ideia de como que aquela coisa acontecia. Era realmente chegar num lugar desconhecido assim, sabe? Pelo menos para a gente na época...e ... recolhendo esses depoimentos depois, a plateia... ops! A plateia ... difícil! Esses termos não se encaixam na minha boca de vez em quando, os participantes da experiência, o público e tal, eles, parece que a experiência invadiu a vida deles de forma quase que total. Assim, tivemos retorno do tipo, comecei a ficar com saudades do personagem, desligava o Facebook e começava discutir sobre o problema, o conflito que a gente tava vivendo,...é...Como a ficção e a realidade eram muito próximas do trabalho, as pessoas começavam a achar que, às vezes, tavam num açougue ,o açougueiro fazia parte da história, por que os limites começavam a se confundir... Então, eu acho que assim, pelo retorno que tivemos, a gente conseguiu criar uma experiência artística acho que única pra aqueles grupos de pessoas e pros outros também. Fizemos também de formas diferentes assim, mas essa primeira que a gente fez tem um carinho mais especial porque, era tudo muito fresco, tudo muito novo, o risco era muito grande assim, então acho... acho que todo mundo ...tava descobrindo junto assim a coisa, o público, os atores... Então foi muito especial e eu acho que a relação deles foi isso assim, eles trocavam...acabavam trocando confidências com os personagens, ouviam confidências dos personagens, e a participação foi total assim, acho que foi surpreendentemente incrível... 
BERNARDO: Tem coisa que esse tipo de experiência, envolvimento do público assim de participação deles...é...acaba ficando muito personalizado assim entendeu? Por que a gente não tem um público muito grande, até uma coisa que a gente propunha lá como se fosse um grupo de pesquisa que era assim "Por que tratar a plateia, como plateia?" e não como A,B,C,D..Luciana, Bernardo e Gustavo, Ana...pensando que com uma tendência lá contemporânea de vida, ou sei lá... Mas a existência é cada vez mais individualizada, nossas escolhas, o nosso tratamento, a gente tem que por login toda hora pra ser chamado pelo nome...então ...esse é um tipo de experiência por ser uma per...so...perso...é personalizado ...então o envolvimento do público ...ele muito disparou, assim tudo tão inteligente que isso, na conversa com o personagem, contava segredos próprios da vida pra uma personagem que é uma ficção. E tinha gente que brigava, que se envolvia a ponto de tipo discutir, ou com um personagem ou com outro participante. Ali tem dois pontos de vistas diferentes, criou se ali uma jorrada de participação onde as pessoas se colocavam como emitiam opiniões, etc. E que, muitas vezes poderiam surgir conflitos e tal, e debates ou grupos das pessoas que fizeram amizade, né? No final de cada espetáculo, eu que sei lá, um participante $X$ que não conhecia um participante $Y$, num acaso se conheceram através da peça podem tá se falando até hoje...

GUSTAVO:... É você tá falando agora, e eu tô pensando em uma coisa aqui, muito louca de isso tudo que você falou, que é, você foi dando exemplos de dinâmica assim muito parecidos com as redes sociais. Sabe, os participantes que se conheceram a partir da peça, os conflitos, as opiniões sendo manifestadas... A gente começou na internet, transportou pra vida real a coisa ,e apesar disso manteve se até um esquema, que a rede social reflete um pouco o que a vida é. Aí o espetáculo acabou refletindo a rede social e a vida juntos. As relações são meio parecidas... eu só...pensei isso, desculpa ...

\section{LUCIANA: E o público acabou modificando o roteiro em especial da peça?}

BERNARDO:...Sim

GUSTAVO: ...Profundamente não.

BERNARDO: .... Porque para a gente fazer o eu, a gente tinha que ter um começo, meio e fim claro, porque se não, ia ser completamente uma loucura inimaginável e a gente não ia ter tempo hábil de preparar as coisas para o público. Então a gente tinha aí uma, um roteiro geral, uma coluna vertebral da dramaturgia que é de onde partimos, como se desenvolve e onde queremos chegar, mas não como um caráter muito engessado assim... Então, pensando aqui em São Paulo, a gente fez três apresentações, as três tiveram o final, a última coisa, assim diferentes... Agora, não era possível planos ali naquela época com 
experiências, com um roteiro totalmente aberto em que as coisas vão sendo construídas a partir da participação. Lógico que tinha que ter sempre uma coisa preparada pra poder relacionar com o público, né? Então...

GUSTAVO:...A gente tinha uma abertura que principalmente inicial que a gente foi descobrindo fazendo...que é... a gente jogava pro público alguns problemas dos personagens, seja durante o personagem ligar, falar, briguei com o a tal, minha mulher, seja no Facebook, seja encontrando individualmente com um personagem para tomar café e tal e a gente começava identificar esse aqui vai ser amigo desse personagem, esse parece que não gosta desse, esse aqui parece...então ...tira essa, liberado do público por si só se arranjar dentro da história... A partir daí, a gente conduzia um pouco mais a coisa, mas se no meio do caminho ele desse alguma pista que estava querendo mudar de lado ou mudar de opinião etc...acho que a gente permitia que se desse assim, mas sempre com a gente conduzindo esse caminho e sem deixar a história também ir para qualquer lugar e o resultado ser qualquer resultado. Por que não era essa ideia. A ideia era a gente chegar num resultado de uma dramaturgia narrativa com esse final esse tipo de discussão levantada e passando por esses caminhos. Claro que uma coisa ou outra acabava sendo integrada ou acontecia na hora, mas acho que a grande maioria das coisas pro trabalho que a gente faz era sempre conseguir com que as coisas chegassem num objetivo final já pré definido assim...

BERNARDO:... É então só pra esclarecer mais, a gente não tinha uma postura de ignorar, alguma proposta que vinha do público, nesse sentido, sabe? Então se surgia uma, sei lá, algum tipo de resposta de retorno de imediato, com o personagem que não estava totalmente previsto, a gente tentava engolir isso aí e devolver com dramaturgia, mas não nunca vamos fingir que não fez isso, fez isso, vai atrapalhar tudo o que a gente tinha planejado, muito pelo contrário.

LUCIANA: Então o público de certa forma se tornava o personagem também e vocês... acho que de certa forma, havia um percentual de coautoria?

GUSTAVO:...Claro...

BERNARDO:...Sim

\section{LUCIANA: ...A partir do momento em que o público interfere...}

BERNARDO: É porque a experiência, ela se dá em duas vias, né? A partir do momento que a gente chama o público para subir no palco, tecnicamente não tem, se ele não subir no palco não tem espetáculo, né? Então, é coautoria nesse sentido, sim, né? 
LUCIANA: E vocês fizeram apresentação em Munique. Como apareceu esse convite para Munique? E vocês falaram em que língua lá?

BERNARDO:...É! Essa é a maior loucura assim, o projeto tava super assim nascendo né, eu nunca tinha feito mas...aiii... quer dizer tem essa instituição que chama Villa Waldberta, que é uma instituição cultural que tem um programa de residência artística, e naquele ano, eles iam fazer um programa com uma curadoria de um brasileiro que a gente conhece, o Mário, e que conhece nosso trabalho e tal, e que naquele ano ia ter só brasileiros, ia ser meio que uma residência direcionada para brasileiros que normalmente você recebe um cara daqui, um cara de lá....e aí...nesse ano, eles resolveram fazer diferente. Eles disseram: Mário você faz a curadoria e traga artistas brasileiros, de várias linguagens pra ficar aqui três meses. Nosso caso, a gente ficou um mês lá...é....que era pra ficar mais, né? ...mas; Aí foi a partir disso então como Mário de curador conhecia nosso trabalho, um amigo, falou assim pô! Eu acho que vocês podiam fazer isso lá, né? Nossa, aí a gente falou vai ser uma experiência única ...e aí a gente topou, só que aqui a gente tinha feito a mesmo dramaturgia. Sim, porque a gente tinha esses atores que são da Companhia, esses personagens que foram desenvolvidos até junto com esses atores. Tinha muitas coisas de dados pessoais dos atores, da vida pessoal de cada um dos personagens.

GUSTAVO: ...A gente vai abrir um parêntese assim. A gente, isso eu acho uma coisa muito maluca que a gente fez..., mas a gente criou uma, a gênese dos personagens. Ela precisava ser profundamente detalhada, hiperdetalhada, porque eles tinham que estar prontos para resolver qualquer coisa com o público. Se o público perguntasse: "qual faculdade você estudou? Qual era a cor que você mais gostava quando era criança? Nome do seu melhor amigo na escola? Que escola você fez? ". Ele precisava saber isso assim, e mesmo que eles não soubessem, a partir do momento que eles falavam qualquer coisa isso se tornava uma verdade, então tem a ver com a gente também ter que engolir aquilo e trazer para a dramaturgia. Então, a gente fez um trabalho de gênese... e preparação

BERNARDO: ...que a gente viu que pra ficar mais coerente, e mais possível de ter uma experiência, valia bem a gente usar um pouco da experiência pessoal de cada um. Então é o que a gente falou. Vou te dar esse exemplo do piano. Se o personagem falasse que tocava piano, e a pessoa não toca piano, se um dia sei lá por um acaso ele vai encontrar o público em algum lugar e tem um piano. Se não toca piano... toca aí, e ele não toca, nosso universo ficcional em relação à realidade desaba, né?

GUSTAVO: ...Desculpa, mas só um parêntese... te levei pra um outro lugar, você tava falando de Munique... 
BERNARDO:...Mas eu tava falando de Munique, e aí, então é isso. A gente criou essa dramaturgia junto dos atores, dessa gênese dos personagens, aqui. Tal como que a gente vai fazer isso lá, né? Bom, aí a gente começou a fazer também a nossa. Quem conhecemos que tá lá? A gente chegou a fazer contato com um ator alemão, que tínhamos conhecido de alguém, mas aí no fundo tinha uma amiga do Gustavo que tava morando em Berlin uma atriz, performer, Camila Hodi, e acho que a gente chegou na Gabi por uma amiga que falou: "Ah, eu tenho uma amiga que é atriz e mora lá em Munique! ". Não, Munique não. Mas era uma cidade perto de Munique, aí a gente falou: Bom! O que temos né, era essas duas atrizes. A gente pegou e falou: "Vamos pensar numa dramaturgia pra fazer lá" ... Porque é isso...partindo da ideia de que o nosso processo aqui foi a partir também da experiência pessoal dos atores, da vida pessoal de cada um então a gente queria produzir a mesma coisa lá né? Não sei se isso virou um método do Eu Negociando Sentidos, mas era o jeito de fazer...

GUSTAVO:... E tinha uma coisa, e tem uma coisa que... tá... Todo espetáculo que a gente faz, que o espaço incite específico... que a gente também tinha que entender, que história que surgia daquele espaço? Daquele lugar? Daquelas duas atrizes a gente tenta sempre. A nossa dramaturgia, nossas ideias sempre surgem do que a gente tem assim na mão... Acho que foi um pouco assim lá, né?

BERNARDO:..E é por causa dessa linha tênue entre a ficção e a realidade. Então, por exemplo, na dramaturgia de lá, na história de lá, era uma artista que vinha do Brasil, uma brasileira, porque a Camila, no caso morava em Berlim, mas ela não tinha o alemão tão fluente. A Gabi era professora de alemão, então a Gabi se passava por uma alemã se precisasse, mas a Camila não, ela tinha um forte sotaque de estrangeira que sabe falar alemão. Então a gente falou: "A gente não pode falar que você é alemã, então você é uma brasileira que foi pra Alemanha...então você é uma brasileira que foi pra Alemanha numa residência na Villa Wamberta". Então, quer dizer, tudo acaba se tornando naturalmente trazendo os dados da realidade. Para isso aí, a gente criou com elas uma alta história e aí etc... teve um formato diferente daqui. Que são outras concepções e o processo bem mais rápido, né? A duração era um mês para gente fazer tudo, né? Mas daí uma interrogação que tinha era assim: E os alemães? Como que eles vão? É que a gente tem aqui o senso comum que lá o povo é um povo frio. Não vão se relacionar com os personagens? Não vai ser legal? Aqui a gente já tem essa cultura da rede social forte no Brasil, no Facebook aqui, sei lá o Brasil acho que deve ser o primeiro ou segundo país que tem mais acesso, e a gente precisa da ferramenta e aí... Mas na verdade o que a gente notou lá, foi que a participação nas redes sociais é muito intensa... 
GUSTAVO:... Mais do que aqui, né?

BERNARDO: Mais do que aqui não tanto quanto uma questão informal de pessoal, de fofoca, e como fala aquilo em inglês aquele termo mesmo? Chit-chat?

\section{LUCIANA: Bate-papo?}

BERNARDO: Bate-papo, não tanto de bate-papo, mas assim quando eles mandavam uma mensagem para o personagem. Era um texto, a gente tinha que ler, e aí sempre com a ajuda das meninas, né? Que então elas traduziam, eu tava lá com elas, e elas traduziam, faziam números por Skype, não sei o quê, e pensavam em conhecer alguns caminhos por aí, mas eles escreviam... Até lá, a gente teve uma coisa muito curiosa que foi: Um dos participantes do público brigou efetivamente com outro participante do público por causa de pontos de vista de que decisão a personagem deveria tomar. Como se fossem amigos conselheiros, sabe assim, um fala uma coisa ou outro fala outra, e aí porque é isso, você não entendendo, você tá pensando nisso, nisso e nisso... ai o outro debatia...Ah! Quer saber? Cansei disso aqui! Cansei desse jogo... e saiu fora.... Saiu fora...então, quer dizer, ele se envolveu, né? Lógico que o encontro presencial lá...era um pouco menos festivo que aqui. Aqui a gente abraça mais fácil, lá é um pouco menos, mas no sentido de envolvimento, passar o tema da dramaturgia foi igual...

\section{LUCIANA: Interessante! E vocês utilizaram alguma referência anterior? Tiveram} influência de outros artistas nessa criação?

BERNARDO:.Até por causa da dramaturgia...O Leo, que é o personagem principal, um dos protagonistas, ele, quer dizer são três personagens, mas ele é performer. Ele começou como artista plástico e foi virando um performer, mas então a gente estudou um pouco de performance, né? Mesmo pra gente ver, e a gente viu que tinha muita coisa a ver com a personagem do Leo que tinha uma pesquisa em performance mas que acabava sendo até uma metalinguagem da nossa pesquisa com a nossa companhia de teatro. Então quando, quer dizer, quando a gente assistia os vídeos da Mariana Bravovich para preencher uma coisa do Leo, a gente acabava aproveitando isso pra essa companhia, pra experiência do Eu como um todo assim...Agora...

GUSTAVO: Eu me lembro que a gente um dia assistiu um filme da Christiane Jatahy, que é "A Falta que nos move". Já viu ou não? "A Falta que nos move"?

\section{LUCIANA: Ainda não...}

BERNARDO: É verdade... 
GUSTAVO: Que tinha, hã...é uma ficção, doc- ficção, né! Uma espécie de documentário, filme ficcional assim, que era uma peça de teatro e que virou um filme. E que eram atores que tava numa casa se eu não me engano preparando um jantar pra alguém que vai chegar e essa pessoa nunca chega, mas os atores tinham o texto, mas também tinham liberdade para abusar, e abusavam e o filme misturava tudo meio que realidade e ficção. Acho que isso foi um filme que abriu nossa cabeça pra algumas coisas nesse sentido...

BERNARDO: É teve a peça lá da qual a gente viu na Lapa que é na... Vila Olimpia...

GUSTAVO: É, mas acho que nem tanto em formato assim... Ah! Livros tipo o que a gente lia muito na época lá o ... Sociedade do Espetáculo, o... Sociedade do Espetáculo, é hã....Teatro pós-dramático, que que a gente leu? "O poder do Mito". Putz!

BERNARDO: Não é? E tem essas referências do que a gente falou igual lá, que a gente falou do Centro da Terra, do Ricardo Karmman, do Donassi, que fizeram essas experiências de inclusão do público na obra artística ....agora é isso eu acho, né? Com rede social, uma coisa assim transmídia a gente não chegou a...

GUSTAVO: É, não sei. Eu acho que assim a gente, tava muito assim e tá preocupado em tentar olhar pro contemporâneo assim, mais do que buscar referência. Parece meio ...burro falar assim, né? Até prepotente, mas não é mesmo o caso, mas é ... a gente pesquisa algumas coisas bem pontuais que a gente sente a necessidade de entender um pouco melhor do assunto, mas, acho que o nosso lugar de pesquisa de referência é o cotidiano assim, sabe...é, não sei tem uma notícia que você falou, olha que loucura isso! Olha essa discussão que interessante. $O$ tal Teatro da Vertigem é um grupo que a gente certamente já falou bastante na época das experiências que eles faziam! Tem tipo leque de referências gigantesco assim, ...e, a partir disso, então a gente constrói ...

BERNARDO:...Mas o que atraía também era essa discussão de algumas performances notáveis. Assim, sabe porque como a gente tava lidando com essa linear de realidade e ficção, então teve algumas performances tipo assim tipo essa do Cris Bollen Tomava um tiro, acho nos anos 60 tal, que era na galeria ..

GUSTAVO: A gente fez dos coiotes também, não foi isso?

BERNARDO:... Ah o...Joseph.

GUSTAVO:...Tá tudo bem, mas era um cara que ficava vivendo com um coiote, durante sei lá, um tempão e no final acabava se relacionando lá com ele.. 
BERNARDO:... Ah! O Dani trazia, efeitos AEE.

GUSTAVO:...Também...

BERNARDO: Chinês...então tinha ...é tinha uma coisa....

\section{LUCIANA: É...A pergunta capciosa: existe previsão para o lançamento do documentário?}

BERNARDO: Ah!...isso é uma novela, né?

GUSTAVO:..É porque já virou outra coisa né? Na verdade, né?

BERNARDO: É, eu falei um pouco antes de que o projeto foi assim se aprimorando nesse sentido, né? Mas... como era uma coisa nova... e ainda é pra gente, a gente precisa saber lidar mais. Como é uma coisa nova e a gente foi descobrindo possibilidades e foi abrindo novos caminhos. Então por exemplo, pintou a Alemanha pra ir, que não tava programada pra ir, a ideia é a gente faz o Eu e edita esse documentário, né?... Hã, até porque da primeira vez que a gente fez, que foi um workshop. Dessa primeira experiência a gente perdeu muita imagem, a gente teve um hd que deu problema, e meu, a gente ficou, rodou. Eu lembro que eu levei o HD, sei lá, na Vergueiro lá, que tinha uma empresa que era fudida pra recuperação de dados e tal, e não conseguiu recuperar. Então assim a gente perdeu muita coisa. Bom, a gente já tinha ideia de fazer mais vezes, se fazer mais vezes a gente pega essas imagens e faz um documentário, e ai nessa ideia de fazer o documentário pintou a oportunidade da Alemanha. "Ah, não dá pra fazer", porque a feitura desse documentário a princípio ia ser nós, a gente que edita né, que ia criar esse roteiro. Não é uma equipe né, a gente não tinha uma verba para fazer esse documentário. $E$ ai veio a Alemanha, aí depois da Alemanha, a gente ganhou um edital da prefeitura pra fazer uma história de desenvolvimento, né, de projeto assim, pra fazer disso um projeto de uma websérie..dessa história..

\section{GUSTAVO: Transmídia...}

BERNARDO: Transmídia...uma WebSérie transmídia, e aí bom, ganhamos o edital, fomos fazer o projeto, que era de desenvolvimento. Era pra você montar um projeto, tem que ter um piloto. Então a gente se debruçou sobre isso, e isso foi acabando, foi né, o projeto acaba, sei lá... mudando de caráter...

GUSTAVO:..E nesse momento a gente tá, com a WebSerie pronta, o roteiro pronto, o teaser feito, o plano de negócios certo...Mas pelo caráter hiperexperimental da coisa e por a gente não ter um histórico em áudio visual a gente tá encontrando dificuldade para realizar 
financeiramente a coisa, mas a gente vai fazer, assim que a gente. Agora a gente tá fazendo um outro trabalho que o PROAC, que a gente precisa terminar... mas acho que assim que a gente conseguir terminar as coisas que a gente já começou a fazer nesse período a gente vai debruçar pra fazer e transformar numa WebSerie, documentário ficção que vai unir também um pouco da, talvez registros passados com outras coisas e transformar esse documentário numa coisa um pouco maior assim...

\section{LUCIANA: E essa Websérie está pronta?}

BERNARDO: E então ela tá com.... roteirizada já. A gente tem esse teaser que a gente produziu a partir desse edital da prefeitura que a gente ganhou, mas a produção em si ...Porque quer dizer...depois que a gente desenvolveu esse projeto desse edital, a gente fez um, se aliou a uma produtora de cinema, né, e vídeo e tal, que tem uma expertise maior de mercado, então falaram, que tinha potencial comercial para a gente fazer com dinheiro de verdade, fazer uma coisa bem profissional. Então a gente apostou, isso demorou um tempo até você ter as negativas, bate na porta de um lá, agora não é momento, só que ao mesmo tempo a gente tem pressa de fazer isso logo, que vai ficando velho até pra gente, né? A gente acaba se envolvendo em outros projetos tal...então a produção em si não. A gente até nesses últimos momentos, sei lá, no final do ano passado e tal, a gente tava tentando vender isso pra fazer com uma grana de verdade e aí acabou não rolando por $\mathrm{N}$ motivos e a agora a gente tava vendo outros caminhos, da gente poder produzir independente também, como foi o Eu... produzido independente...então ainda não produzimos, né?

GUSTAVO: Mas tá em vias de...

\section{LUCIANA: Na concepção de vocês o que é um artista transmidiático?}

BERNARDO: Ah! Eu acho que...eu não sei se isso é uma...tipo: Ah! Tem um artista plástico, um artista visual e não sei que tem um artista transmidiático. Não sei se é uma categoria nesse sentido...

GUSTAVO: É...e se pegar...

BERNARDO: Se o cara fez um trabalho que denomina se transmídia ele é um artista transmidiático...

GUSTAVO: Eu não sei eu acho que, sei lá, hoje em dia depois de quase 5 anos de companhia eu acho que a gente pode falar que, somos artistas transmidiáticos porque quando a gente pensa em criar obras a gente quase que não consegue pensar de forma 
convencional. Assim, a gente já pensa, ou já tem um olhar aberto pra plataformas seja..hã, sei lá qual nome daquilo? Periscope, que é uma tecnologia nova que talvez a gente queira usar em projetos, que tá com olhar aberto pra novas plataformas e potencialidade dessas plataformas de se, trabalhar com dramaturgia...Então acho que nosso olhar é um olhar de artistas transmidiáticos nesse sentido, mas acho que isso é ter o olhar meio que automático pra pensar a arte a partir disso assim, mas num sei se é isso...

LUCIANA:.É...hum!hum!...Vocês acham que o público valoriza mais uma obra em que possa atuar ativamente, do que observar passivamente?

BERNARDO: O público...

GUSTAVO: ...falar em geral e difícil..., mas eu acho que é uma tendência.

Eu acho que é uma tendência, né? Porque as pessoas estão sendo treinadas pra isso. Essa relação via rede social e possibilidade de se manifestar, de interagir, personalizar conteúdos, é uma tendência. Eu acho isso vem se refletir na hora que você interage com uma obra. Você, hoje, tem vontade de pegar a coisa, encostar, de fazer parte da coisa de, sei lá, de opinar sobre a coisa e acho... acaba, vai acabar se refletindo no fazer artístico, assim, né? Acho que o meio que influencia, né?

LUCIANA: E vocês têm percebido a transmídia como tendência dentro do cenário artístico nacional e internacional?

GUSTAVO: Internacional, sim.

\section{LUCIANA: Nacional não?}

GUSTAVO: Não sei! Sabe por que não sei? A gente, por exemplo: A gente faz esse trabalho e acho que ninguém conhece a gente direito assim sabe, e talvez existam outros grupos, aí fazendo, que a gente também não conhece porque, quer dizer a gente sabe que existem, acho que o fila 7 tem um trabalho que tem alguma coisa de transmídia, se não me engano. Mas como não acaba tendo um espaço gigantesco em grandes mídias ou ainda não é hipervalorizado esse tipo de pesquisa que é experimental. Ah não sei , eu sei que assim lá fora a gente tem tido um olhar mais focado pra fora do país, porque inclusive a gente foi pra Portugal agora fazer um trabalho. Porque a gente percebe que, fora isso, já é mais comum assim e isso já acontece com mais naturalidade. As pessoas consomem, entre aspas, esse tipo de trabalho, de produto, querem ver, participam, é mais natural... Aqui no Brasil, acho que não sei, acho que ainda não ...é uma tendência que tá engatinhando ainda eu acho, mas acho que já se fala mais do que quando a gente começou a fazer o 
“Eu”...sabe? Né? Você tem aí o Eratransmídia ...cê pode até falar melhor deles, sei que é um grupo, um instituto, associação...

BERNARDO: É tipo uma associação. Que dizer? Uma associação. Não sei dizer também que eu não pertenço mas conheci o Fabio Hofling que ele é um cara e agora eu acho que ele tá trabalhando com realidade virtual e aí uma vez eu fui bater um papo com ele tal..., Para ele, transmídia meio que assim pessoas que, se aproximaram pelo gosto de um mesmo tema, e desenvolvem trabalhos em certo sentido até publicitário, que tem muita transmídia e tem encontros periódicos...

LUCIANA: É um grupo de estudo, né? Eu tenho um artigo deles publicado na Gemini.

BERNARDO: ...E quer dizer, uma associação no sentido de pessoas que se reúnem, mas não que sejam organismo oficial, que tenham um respaldo, mas acho que isso já é uma expectativa, de um ato de existir a associação é...dá um certo valor...

LUCIANA: E vocês acham que essa história de Transmídia é uma coisa nova, ou algumas obras do passado poderiam ser consideradas como transmidiáticas?

BERNARDO: ...Puta difícil... Porque não tenho tanto conhecimento histórico assim de História da Arte, nesse sentido. Mas é que eu acho que com as novas tecnologias, isso se tornou um pouco mais visível talvez sabe um pouco mais possível de se realizar. Praticamente assim, sabe. Novas mídias que a gente tá falando é isso, anos 2009 pra cá...

LUCIANA: Que teve uma popularização maior dos meios transmidiáticos?

BERNARDO: ...É... mas com certeza deve ter, acho que com certeza deve ter tido alguma coisa que se refletia assim...

LUCIANA: E vocês já participaram ou experimentaram alguma outra obra transmidiática?

BERNARDO: Ah! Teve aquele filme, né, do Marco Ricca?

GUSTAVO: Qual? O que a gente participou?

BERNARDO: Participou? Não! Participar?

LUCIANA: Participar no sentido, como...

BERNARDO: Público?... 
LUCIANA: É, de público.

GUSTAVO: Acho que... ah! Por exemplo, o Zé Sampaio, um ator também que já trabalhou com a gente na companhia. Uma vez, numa virada cultural dirigiu acho que era o Teatro WhatsApp, alguma coisa assim, em que você chegava no SESC, e conversava com o personagem via WhatsApp, e tinha que fazer ações com pessoas ali, ler algumas coisas, etc. De alguma forma, aí...

BERNARDO: Mas aí acaba não sendo transmídia...que era no WhatsApp...

GUSTAVO: É, mas, de alguma forma ,papel com mídia, ler algo, e sei lá, não sei bom..

LUCIANA: Essas fronteiras ainda não estão muito claras, principalmente dentro do universo artístico, vocês acham isso?

BERNARDO / GUSTAVO:...É...

GUSTAVO: Eu acho que sim...

LUCIANA: Vocês acham que a Transmídia é abordada de forma comercial como no cinema? Na publicidade, ela tem uma leitura diferente do que a leitura que é feita nas artes plásticas, de forma geral, artes cênicas, etc.?

BERNARDO: Eu acho... que nas artes é um trabalho muito mais complexo nesse sentido, não desmerecendo os trabalhos dos publicitários também. Mas eu acho que essa transmídia na publicidade tem um certo utilitarismo. Assim que acaba, você não tem uma necessidade de transformar a história daquele produto em outra mídia assim, mas é um transmídia comercial, então... não é essência que te leva lá, é justamente o não. A gente precisa fazer que seja na tv ali, e também seja não sei aonde ..fica um mercado

GUSTAVO: É teve uma cena... teve aquele filme que o Daniel Oliveira fez, que eu não me lembro quais que... Esse, o Braga, se não me engano que ele falou...eu lembro na época que...saiu a notícia: que a primeira série ou filme transmídia do Brasil... Eu falei: "Nossa, vamos ver isso pelo amor de Deus". E aí era, na verdade, um filme que era depois dividido em episódios na internet, e também passava na TNT, e que cada um deles tinha um enfoque diferente. Assim: Numa você via bastidores, no outro não mas pelo que a gente viu por ser transmídia, não acreditamos, achamos que aquilo era efetivamente transmídia, eles só pegaram uma coisa e dividiram... 
BERNARDO: É quase que pra mim, dando minha opinião, mas é quase que assim. Eu li um livro que virou um filme. Isso não é transmídia, é transposição de alguma coisa. Eu fui assistir esse filme no cinema e pretendia assistir os bastidores no Youtube , ou uma sequência da série que era no TNT. Pra mim, era mais um foco comercial, tipo vamos aumentar mais nosso mercado assim...não me leva a uma essência teatral mas uma certa dramaturgia, né? Não precisa construir um caminho no tempo, no espaço, nas mídias. Não é só simultâneo, aí eu vou fazer um programa de TV que é filmado e transmitido na internet, isso não é transmídia ...Eu acho né!

LUCIANA: Vocês têm planejado outras apresentações do Eu Negociando Sentidos, ou vocês já vão passar para websérie, além de outras coisas, projetos?

GUSTAVO: É... pra fazer a websérie, a gente provavelmente vai fazer uma última apresentação que as pessoas que participaram desse websérie vão ser a base e o fio condutor dessa websérie. Então, a gente vai efetivamente realizar essa experiência cênica novamente e aí vai também criar cenas ficcionais só com atores e incluir isso, pra transformar isso numa websérie. É, então eu tenho aí uma questão que é isso assim: a gente tava falando da tendência da Transmídia no Brasil. Existe uma dificuldade grande de financiar trabalhos assim ainda no Brasil. Acho que fora também, mas lá acho que um pouco menos, sabe? É, a gente tá vivendo num momento onde a Cultura tá sendo, tá diminuindo. Nunca foi grande ainda, então, achar espaço ainda pra esse tipo de trabalho hiperexperimental e muito difícil então, como normalmente. Como a gente fez, foi meio que do bolso assim. E nós termos comerciais, como é que você vende um produto que você fala, vou durar um mês tá! E são 15 pessoas só de público. Tipo, não tem empresa nenhuma que patrocinaria uma experiência dessa, pra dar o retorno que vai dar, então é claro que a gente gostaria de fazer um ano inteiro fazendo vários, várias vivências e experiências dessas, mas o que a gente faz é muito especifico assim e não é ruim. Não quero pensar que é ruim. É legal fazer também uma coisa pra pouca gente uma vez, tem uma potência pura por ser assim também sabe? Mas é difícil de um circuito entrar em cartaz com um trabalho desse, é mais uma experiência independente, e é isso. Ela se dá, e aí a princípio acho que o foco é fazer websérie e criar mais uma experiência dessa, e se a websérie acontecer e alcançar muita gente, isso criar um interesse talvez, a gente aí consiga...

\subsection{Entrevista com Luis R. Lopreto}


Luciana: Na sua concepção, o que é transmídia?

Lopreto: Meios que se complementam para a produção de uma nova unidade expressiva. É a utilização de unidades (obras) em diferentes mídias ou em diferentes áreas de disciplinas (transdisciplinas) diferentes para integrá-las em novos significados.

Luciana: Você acha que o termo pode ser aplicado no universo artístico?

Lopreto: $O$ termo nasceu do universo da produção artística. Basta ver o desenvolvimento das vanguardas modernas e suas inúmeras interações a partir da segunda metade do século XIX, para compreendermos inclusive a possibilidade do advento de novas mídias - cinema - rádio e TV. Como exemplos posso citar a produção e pesquisa expressiva em relação ao movimento na imagem do Movimento Impressionista, particularmente a concepção de Seurat para a Pintura- a unidade mínima que compõe uma imagem é o ponto - realidade essa que irá criar a construção da imagem na TV 70 anos depois...A obra do Poeta Mallarmé "L'aprèsmidi d'un faune" traduzida em partitura por Debussy e depois em Coreografia por Nijinski, produzindo um dos maiores espetáculos transdisciplinares da história.

Luciana: Quando você criou a obra "Fragmentos" já tinha em mente o formato transmidiático?

Lopreto: Sem dúvida. Pesquiso a interação de linguagens artísticas desde a minha formação com meus Mestres - Willys de Castro e Theon Spanudis, ambos neo-concretos. Aprendi com os Mestres (Willys de Castro) a definição: "Arte Constelar - a maneira de uma constelação e suas interações " - , para o que chamamos transmídia ou transdisciplina - termo esse apropriado a boa parte da tradição do desenvolvimento da Arte Brasileira desde o Modernismo de 22 - das relações entre Poesia e Pintura (Tarsila e Oswald por exemplo).

Luciana: Quais critérios usou para escolher as mídias do projeto?

Lopreto: O critério mais importante e fundamental é a possibilidade de construir uma unidade criativa expressiva (obra) com o maior número de interações possíveis entre as linguagens artísticas - é minha proposta de poética! Sou Poeta desde sempre e é a poesia que norteia todas as possibilidades de interações entre 
as linguagens da arte de maneira mais direta. Parti da criação da série " Fragmentos " - com pequenos poemas rítmicos, quase paisagens - internas e externas - isto porque é na poesia que o ritmo, ou seja, o elemento mais interpenetrante da expressão se torna mais universal aos sentidos. Seguem-se as partituras na música e em seguida traduzida em movimentos do corpo para a dança na construção de uma imagem//pintura feita com luz (uso de pequenas lanternas na mão que configuram em linhas os movimentos). Enquanto danço ao som ao vivo da música para construir uma pintura feita com luz, os atores interpretam o poema em performances de variações múltiplas e livres. Capturando a performance, fotógrafos e videomakers se posicionam de forma 3D na cena, produzindo séries de fotos e vídeos. 